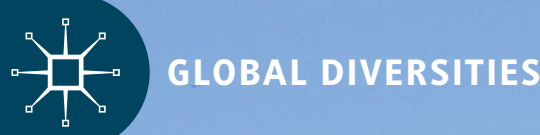

Open Access

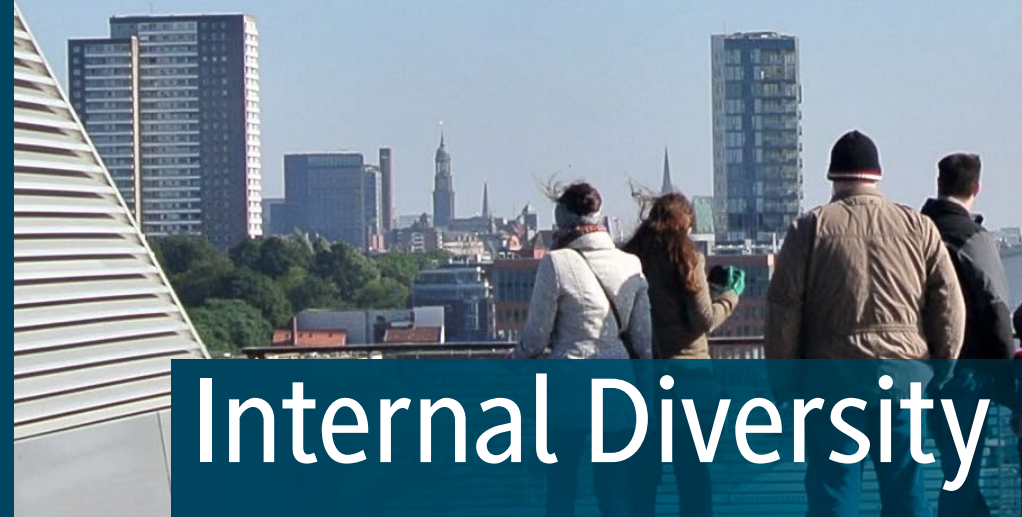

Iranian Germans Between

Local Boundaries and Transnational Capital

Sonja Moghaddari 


\title{
Global Diversities
}

\author{
Series Editors \\ Steven Vertovec \\ Department of Socio-Cultural Diversity \\ Max Planck Institute for the Study of Religious and
}

Ethnic Diversity

Göttingen, Germany

Peter van der Veer

Department of Religious Diversity

Max Planck Institute for the Study of Religious and

Ethnic Diversity

Göttingen, Germany

Ayelet Shachar

Department of Ethics, Law, and Politics

Max Planck Institute for the Study of Religious and

Ethnic Diversity

Göttingen, Germany 
Over the past decade, the concept of 'diversity' has gained a leading place in academic thought, business practice, politics and public policy across the world. However, local conditions and meanings of 'diversity' are highly dissimilar and changing. For these reasons, deeper and more comparative understandings of pertinent concepts, processes and phenomena are in great demand. This series will examine multiple forms and configurations of diversity, how these have been conceived, imagined, and represented, how they have been or could be regulated or governed, how different processes of inter-ethnic or inter-religious encounter unfold, how conflicts arise and how political solutions are negotiated and practiced, and what truly convivial societies might actually look like. By comparatively examining a range of conditions, processes and cases revealing the contemporary meanings and dynamics of 'diversity', this series will be a key resource for students and professional social scientists. It will represent a landmark within a field that has become, and will continue to be, one of the foremost topics of global concern throughout the twenty-first century. Reflecting this multi-disciplinary field, the series will include works from Anthropology, Political Science, Sociology, Law, Geography and Religious Studies. While drawing on an international field of scholarship, the series will include works by current and former staff members, by visiting fellows and from events of the Max Planck Institute for the Study of Religious and Ethnic Diversity. Relevant manuscripts submitted from outside the Max Planck Institute network will also be considered.

More information about this series at http://www.palgrave.com/gp/series/15009 


\begin{abstract}
Sonja Moghaddari
Internal Diversity

Iranian Germans Between Local

Boundaries and Transnational Capital
\end{abstract}


Sonja Moghaddari

Department of Sociology and Social Research

University of Trento

Trento, Italy

ISSN 2662-2580

ISSN 2662-2599 (electronic)

Global Diversities

ISBN 978-3-030-27789-5

ISBN 978-3-030-27790-1 (eBook)

https://doi.org/10.1007/978-3-030-27790-1

This publication was financially supported by the Swiss National Science Foundation (SNSF).

(C) The Editor(s) (if applicable) and The Author(s) 2020 This book is an open access publication.

Open Access This book is licensed under the terms of the Creative Commons Attribution 4.0 International License (http://creativecommons.org/licenses/by/4.0/), which permits use, sharing, adaptation, distribution and reproduction in any medium or format, as long as you give appropriate credit to the original author(s) and the source, provide a link to the Creative Commons licence and indicate if changes were made.

The images or other third party material in this book are included in the book's Creative Commons licence, unless indicated otherwise in a credit line to the material. If material is not included in the book's Creative Commons licence and your intended use is not permitted by statutory regulation or exceeds the permitted use, you will need to obtain permission directly from the copyright holder.

The use of general descriptive names, registered names, trademarks, service marks, etc. in this publication does not imply, even in the absence of a specific statement, that such names are exempt from the relevant protective laws and regulations and therefore free for general use.

The publisher, the authors and the editors are safe to assume that the advice and information in this book are believed to be true and accurate at the date of publication. Neither the publisher nor the authors or the editors give a warranty, express or implied, with respect to the material contained herein or for any errors or omissions that may have been made. The publisher remains neutral with regard to jurisdictional claims in published maps and institutional affiliations.

Cover image (C) Sonja Moghaddari

This Palgrave Macmillan imprint is published by the registered company Springer Nature Switzerland AG. The registered company address is: Gewerbestrasse 11, 6330 Cham, Switzerland 
To my loved ones Past, present, and future 


\section{Acknowledgments}

Writing this book seemed to me like doing pottery: over and over, I looked at the clay, I weighted it in my hands, wedged it, molded it to sculpt it into a form I thought was fitting. Then I set it aside, but looking at it again after a while, I tried out new shapes, until I had it standing stably on its own. I am very happy and incredibly grateful for having had the chance to have numerous people who, each in their own way, accompanied me through all the different stages of this research and writing experience.

I would not have been able to write this book without the openmindedness and the interest of my interlocutors in Hamburg and elsewhere, who allowed me to dive into their world and carry out in-depth long-term ethnographic fieldwork. To each and every one of them, I am highly indebted. As it is impossible to cite them all, I would like to stress my particular gratitude to "Babak", "Milad", and "Solmaz", who did not only share their thoughts and experiences, but also offered me their friendship. My special thanks go also to "Siavash", who shared my fascination with the history of Hamburg's early Iranian merchants. Many thanks to "Behruz" for having allowed me to be a-not always easy-volunteer in the Color festival, and to the "Golestanis" who helped me to develop new feelings of belonging.

This book would not have taken the shape it did without the inspiration of brilliant, insightful, and supportive colleagues and mentors. I am 
particularly grateful to Alessandro Monsutti not only to have allowed me to deepen my understandings of transnational inequality, but also for his availability and reliability as an advisor during my doctorate, on which this book is drawing. A thousand thanks to Christian Bromberger who has been a serene, engaging mentor and an important model of a mindful ethnographer, since he sparked my interest in the anthropology of Iran when I first met him as an undergraduate student in Hamburg. Dast-e shomâ dard nakone. As a third mentor and friend, I will thank Cristian Alvarado Leyton's encouraging guidance and uneasy questions. He taught me to believe in myself and the value of migrants becoming anthropologists.

I am thankful to Yvan Droz, Sandro Cattacin, and Sabine Strasser for their thoughtful comments on earlier versions of this work as members of my thesis committee. I further wish to thank Frédéric Saumade, Shalini Randeria, Gaetano Ciarcia, Anja Weiss, Thomas Faist, Anne-Christine Trémon, Susanne Bygnes, and Amin Moghaddam for academic guidance and constructive feedback. I thank Steven Vertovec for his support as a mentor and series editor. Thanks also to Christiane Kofri, Birgitt Sippel and the Palgrave team for the logistical help in the publishing process.

I further wish to thank my friends and colleagues from the Graduate Institute, Claudie Fioroni, Ieva Snikersproge, Flavien Renaud, Nick Miszak, Claudio Todisco, Khadija Abbasi, Adele Galipò, Andrew Silva, Melusi Nkomo, and Jean Chamel, for having made up such a thoughtful and stimulating company. In Göttingen I would like to thank my colleagues at the Max Planck Institute for the Study of Religious and Ethnic Diversity for the discussions and inspiration, and in particular Miloš Jovanović, Julien Debonneville, Scott MacLochlainn, Sabine Mohamed, Michalis Moutselos, Elena Gadjanova, and Alexandre Tandé. I also wish to thank Veronica Davidov for having offered her editing skills for this work.

It was my luck that I did not need to work as a waitress in Iranian restaurants - one of my research methods — to finance my studies. Several grants received from the part of the Vahabzadeh Foundation and from the Graduate Institute of International and Development Studies largely facilitated the realization of this research. Postdoctoral research grants from the Swiss National Fund for Science allowed me to give this manuscript its final shape as a book. 
Without the company of good friends- the laughter, the dancing, but also the shared insights and skills—completing this book would have not been imaginable. I would like to thank Jil and Yaël, Paula and Lena for having enhanced my stays in Hamburg with their beautiful presence, besides, of course, having been generous hosts when I needed a place to stay. Across Switzerland, France, Germany, and Italy, I am feeling blessed by the company of Pierre Luisier, Valentina Princivalle, Karin Fockens, Sophie Martinelli, Annina Meyer, Magnus Meister, Monique Beerli, Aurélien Riondel, Julien Delfosse, Cédric Jenni, Zeinab Aghamahdi, Anaïs Nicolas, Églantine Gauthier, Laura Eger, Valentina Anzani, Sam Kia, and —imagine me smiling - Aliakbar Rezapour, my dear partner: thanks for having shared the joys and endured the pains of the writing process with me.

I thank my mother, Anita Rabenstein, with her light green eyes, and my father, Mohammad Moghaddari, with his walnut brown eyes, that have always looked at me with much love. I thank my sister Shirin Moghaddari and my dear family close and distant in Germany and Iran-it is not least our different identifications that helped me to understand the complexities of belonging. Unendlich vielen Dank! 


\section{Praise for Internal Diversity}

"Sonja Moghaddari documents the social life of people of Iranian descent in the German city of Hamburg. Through suggestive ethnographic vignettes, in constant dialogue with theoretical discussions, she depicts subtle processes of social differentiation. The book harmoniously brings together local, national and transnational dimensions."

-Alessandro Monsutti, Professor, Department of Anthropology and Sociology, Graduate Institute of International and Development Studies, Switzerland

"Sonja Moghaddari's study on Iranian-Germans is a vivid ethnography of an understudied migrant group, enhancing our understanding by providing a valuable historical perspective. Beyond the empirical insights, Moghaddari also makes an important contribution to our understanding of cultural capital in migration, through a perceptive analysis of differentiation, the workings of capitals across fields and the politics of value. While contributing to nuanced scholarly debate, the book's lively style makes it compelling reading for academics and students."

—Umut Erel, Senior Lecturer, Faculty of Social Sciences, The Open University, $U K$

"With a keen ethnographic eye, Sonja Moghaddari delves into the histories and present-day worlds of Iranians in Hamburg, Germany. Across several strategic case studies of familial and professional ties, she reveals how transnational capital and kin networks shape local boundaries of social status and difference. A significant contribution to the field of Iranian Diaspora Studies, this is a highly readable, engaging book that brims with original insight into an understudied population and phenomenon."

—Neda Maghbouleh, Assistant Professor, Department of Sociology, University of Toronto, Canada

"An empirically rich and theoretically informed analysis of the interlinkages between diversity and transnationality among Iranian-Germans."

-Boris Nieswand, Professor, Institute of Sociology, University of Tübingen, Germany 


\section{Contents}

1 Introduction 1

2 Cohesion and Conflict in Transnational Merchant Families 39

3 Narrating “Traditional Iranian Carpet Merchants” 81

4 An Association Between Diversity and Exoticism 125

5 The Overlapping Uncertainties of Film Professionals 163

6 A Festival at the Interstices of Value Systems 197

$\begin{array}{lll}7 \text { Conclusion } & 227\end{array}$

$\begin{array}{ll}\text { Index } & 245\end{array}$ 


\section{List of Figures}

Image 1.1 Black tea, a tablecloth from Iran and a part of Siavash's family archives at his home. (July 2013, author's photo)

Fig. 2.1 Ali's family tree, all non-specified people live or lived in Germany

Fig. 2.2 Jalal's family tree, all non-specified people live or lived in Germany. The data for the extended family is simplified for reasons of pertinence

Image 2.1 Drawing of the villa Parviz inherited from his German parents-in-law. (April 2014, author's photo)

Image 2.2 Christmas 1938 and Emma's mother's place. From right to left: Emma's sister's husband, Ali, Emma's sister with Gita, Emma, and her mother (Siavash's family archives)

Image 3.1 View on the warehouse district (Speicherstadt) from the Poggenmühlenbrücke. (June 2013, author's photo)

Image 3.2 Street view in front of Akbar's store. (June 2013, author's photo)

Image 3.3 Akbar's show room with view on a fleet. (June 2013, author's photo)

Image 3.4 Tea set from Iran on a hand-knotted Persian carpet. (June 2013, author's photo) 
Image 3.5 Foundation stone ceremony of the Imam Ali mosque in February 1960. Hamburg's Senator Kurt Sieveking on the left, and Imam Hojatolleslam Mohammad Mohaghaghi on the right (Siavash's family archives)

Image 3.6 Utility vehicle of the merchant business Hassan Vladi, probably the 1950s (Parviz' family archives)

Fig. 3.1 German import of hand-knotted carpets from selected countries between 1996 and 2014 (in thousand Euro, product codes: WA57011010, /90, /91, /93, /99, and WA57019010, 190). (data: Statistisches Bundesamt 2015, graphic by the author)

Image 4.1 Young men whose clothing and hairstyle mark their honari identification at Khâneh honarmandân, center of contemporary art, Tehran. (February 2014, author's photo)

Image 4.2 A store in central Tehran selling honari artifacts. (February 2014, author's photo)

Image 4.3 Golzar dances in front of German journalists in her living room. (April 2014, picture taken by a member of the film crew with the author's camera, anonymized)

Image 6.1 Hochsieben's main hall with Sebastian's photo exhibition. (June 2013, author's picture)

Fig. 6.1 Behruz' potential Iranian allies and their positionalities at the intersection of tridimensional social fields 


\section{1}

\section{Introduction}

I get up and turn on my phone, remembering a message I received from Babak ${ }^{1}$ yesterday. "Sorry, I have to work this weekend and I won't be able to be with you [at the festival]." This is strange, I think. I know he sometimes works on the weekend. Babak is an artist in his early forties. But Milad, our common friend, told me that they were hanging out together yesterday evening. There must be some other reason why he won't come. It's the same for Milad, who did not follow up on my invitation, either. It's a sunny Saturday in June 2013. Yesterday, I worked late: I am volunteering to help Behruz, a 27-year-old German-born man of Iranian origin, a student, organize the Iran-centered Color festival at Hochsieben, one of Hamburg's most important avant-garde art venues.

When the 120 guests left after the ethnic (mahali) and traditional (sonnati) music concert yesterday, I heard a German technician ask Ziba "[Here lives] Europe's biggest Iranian community - where were they tonight?" The cultural organizer in her mid-forties answered "Well, Behruz's aim was to attract a German public and he succeeded in doing so $[. .$.$] . If Iranians have to choose between several similar concerts, they$

\footnotetext{
${ }^{1}$ All names of interlocutors, associations, and events, in some cases also personal data, were changed in respect of their privacy and personal security.
} 
will come to see Taghi tomorrow" (field notes June 2013). Taghi is a famous classical Iranian music singer based in Iran. In our last reunion, Behruz said that he expects violent contestation at the festival in response to Taghi's political position-taking in the recent Iranian presidential elections.

My phone beeps. Yara writes that she is free today and asks if we need help. Apparently, Behruz doesn't pick up the phone. Yara, an educator in her early thirties, has not been actively involved in the organization of this festival for months. Plus, as a member of the association Golestan, she is organizing a festival of young Iranian fusion music in only five months. Why does she want to help all of a sudden? I forward her quest to Behruz, who displays professionalism: "No, thanks, everything is under control." He obviously does not want her support.

At the festival venue, the hall with the photo exhibition of Iranian landscapes fills indeed with a different kind of public than last night. Ziba was right! There are more than twice as many visitors as yesterday, most of them of Iranian origin. I spot her in the crowd and am struck by her feminine elegance. With her red sheath dress, she wears a black hat. The day before, she was dressed much more casually, in correspondence to Hamburg's notorious understatement. "I told you, yesterday was for students, today is the real day", she beams and takes a thousand pictures with all the people she knows. In our interview, she told me that she often feels suffocated within what she calls "the Iranian community". Is she trying to challenge limitations through her slinky dress?

More and more people arrive and mingle. I greet merchants, artists, students, and political activists I know, members of the cultural association Golestan, people I met on the street when we promoted the festival, visitors I never met before, and my own extended family members who I invited. Two young men ask me for my number; a mother presents me to her son. Is the festival a dating market? My relative feels uncomfortable and says that there are many of her pharmacist colleagues. She obviously came to do me a favor.

Suddenly, I hear someone calling me by my family name "Miss Moghaddari!" Yara rushes toward me, energetic as ever and casually dressed in trousers and pullover. She presents me to her two female friends, like herself in their early thirties. One of them makes a compliment 
for the Color festival t-shirt I am wearing: it bears the event's slogan written in minimalist white letters on a royal blue background. Yara, however, contests: "I don't like it." Later she comes back to show me the t-shirts of the competing FusIran festival, explaining "I just received them today." They bear the festival's name in an elaborate font that resembles Persian letters printed in two colors on a dark blue background. "What a funny coincidence", I think.

I catch Behruz at a moment of calm, between distributing flyers and preparing tea. "So how do you think the concert went yesterday?" "It was good but there were less people than I hoped. However, I really did not like when Hassan stepped on stage to dance. He didn't even have a ticket as far as I know" (field notes June 2013). The Iranian man in his sixties improvised Iranian dancing during the last song. Hassan is a modest person and I know him because he distributes flyers and promotions at every Iranian event in town. The public clapped hands to accompany him. Why did Behruz see this joyous performance as a problem, I wonder? Well, at least, there was no sign of a fight, so far.

Offering black tea, cooked in a samovar, on donation is one of my tasks. A woman in her forties, dressed in a feminine way with high-heeled shoes and her long black hair down, asks me to serve her two cups. She is accompanied by a man and a young blond boy, possibly her German partner and son. "It is Persian tea, isn't it?" "No, it's Turkish tea." I show her the package. "Oh, then I'll get just one for my son. This one is too strong. I always drink Persian tea, it's milder." Another woman, a stranger of about the same age, who is dressed more casually and also accompanied by her family, intervenes, "What's the matter? This tea is good!"

Nazanin arrives with her sister and German husband, dressed in a summerly skirt and high-heeled espadrilles. The 62-year-old, whose father was a professor of Iranian Studies in Germany, seems to enjoy the socializing at the festival. "Thanks for offering me the ticket although I dropped out early [from volunteering in the festival organization]. By the way, I tell you this in private, at Hochsieben they made fun of Behruz. He wanted to organize a big event and usually they do not collaborate with newcomers. But my friend Anna made a case for him and I am happy it worked out" (field notes June 2013). Does her getting demotivated from volunteering have something to do with Behruz image at Hochsieben? 
The doors to the concert hall are already closed and Behruz is nervous: some people on the guest list have not yet arrived. Is it an accident that the man who at last hurries in with his family_and thus evades the preconcert sociability - is the representant of the local Iranian-run Imam Ali mosque? For the encore, the public requests a song called "Vatanam" ( $M y$ home country). For just a few minutes, across all differences, the public seems to be moved, in good or in bad, by this first (but not the current) sweepingly emotional Iranian national anthem. It represents a pause from the atmosphere of antagonism that is at the heart of the interactions on this day at the festival.

This set of individual encounters highlight the diversity of positionalities Hamburg-based people identifying (at least partly) as Iranians ${ }^{2}$ (Iraner) take in relations to one another, here in the context of this Iranian cultural event. The encounters reflect, following Pierre Bourdieu's approach to the study of power and inequality, subjacent micronegotiations over the criteria by which agents evaluate each other's ideas, objects, and practices (Bourdieu 1979). They appear as practices of social differentiation. A struggle is the essential feature of a social field (Bourdieu and Wacquant 1992). It is in the context of such systems of relations that individual encounters take all their meaning. How do agents weigh between attendance and abstinence, choose their clothing and behavior at the event, and evaluate that of others? Considering that agents are migrants, ${ }^{3}$ which local and transnational social relations play a role in their decision? How do they evaluate the influence it will have on them? In other words, how do dynamics in different local and transnational social fields, and their prevalent systems of evaluation-hence, of value-interrelate?

People constructed as a cultural or racial Other form an integrate part of today's Western societies. While migration studies shed light on many

\footnotetext{
${ }^{2}$ I use this emic appellation throughout the book. Importantly, it does not discriminate between people who migrated themselves and those who were born in Germany. It will become clear by the conclusion why the title bears the notion of Iranian-Germans, instead.

${ }^{3}$ For reasons of readability, I will use this term throughout the book. It also corresponds to the way people with non-German identifications tend to be constructed in German society, namely as migrants or foreigners (Ausländer). However, numerous interlocutors in this study, in particular those who could be considered second-generation migrants, did not migrate themselves and the Iranian is only one among several national identifications.
} 
aspects of their presence in these countries, relations among migrants from the same country of origin are understudied due to dominant paradigms that privilege their interaction with the society of residence and origin or altogether non-ethnic approaches. Yet, diversity in local ingroup relations is crucial to understanding social cohesion in contemporary societies of immigration. This is particularly urgent in times of the European border regime's crisis, where the question of migration has become a subject of political maneuvering; in times in which the traditional party system is destabilized by the rise of populist, nationalist, and extreme right forces to power positions in national governments where racist violence is seeing a drastic increase across the continent (Jäckle and König 2017; Vertovec 2018).

Extant research on such internal diversity reveals that processes of differentiation are related either to migrants' conditions of incorporation in the locality of residence or to their pre-migratory social context. Transnational reasons for these dynamics, however, are rarely examined in enough detail. Conversely, an emerging strand of research focuses on how migrants create different forms of capital in transnational social fields, but tends to neglect the connection with local dynamics. This book asks how diversity among Iranian-Germans, as it derives from processes of social differentiation, relates to their past and ongoing historically situated experience of generating capital in local and transnational social fields.

\section{Internal Diversity}

When the transnational approach to migration became dominant in the early 1990s, it was conceptualized as a "transgressive movement" that challenges, through cross-border circulation, dominant ideas, and practices linked to nation-states and, in general, to the global political economy (Glick Schiller et al. 1997, 136f.). Accordingly, transnational migrants are seen as acting in contestation of and in confrontation to power structures such as national institutions and multinational corporations. Portes, Guarnizo, and Landolt, for instance, conceive of transnational activities as being "commonly developed in reaction to governmental 
policies and to the condition of dependent capitalism fostered on weaker countries" (idem 1999, 20). These research trends nourish the development of what I call the "paradigm of internal horizontality", according to which migrants are agents of change that engage in vertical relations with structures and institutions of their societies of origin and residence, while internal relations remain largely horizontal.

As a consequence, studies that reveal unequal relations among migrants did not receive enough attention. Their findings, however, forcefully argue against the idea of internal horizontality, as does for instance Pnina Werbner's (1990) work on Pakistani entrepreneurial families in Manchester. Social differentiation among migrants evolves "in response to the changing communal and economic contexts" (idem 1990, 342) in local and in transnational social fields. Ludger Pries (1996) and Michael Smith (2005) also stress that migrants' social spaces are heterogeneous and shaped by relations of power.

Eventually, the conceptualization of migration as transgressive movement became criticized for its dualistic and romanticizing vision. Likewise, the paradigm of internal horizontality was gradually superseded by what I identify, building on an expression of Carter and Fenton (2010), as the "paradigm of not-thinking-ethnicity".

The early 2000s saw the rise of a critique of "methodological nationalism", postulating that the analytical centrality of nation-states had left research conceptually blind for processes that cannot be grasped in terms of national belonging (Wimmer and Glick Schiller 2002, 324ff.). Taking further Brubaker's (2002) important argument for the use of ethnicity as a category of practice instead of a category of analysis, the debate entails a critique of the ethnic lens, with the argument that research had fostered the construction of "migrant communities" based on a common ethnic or national origin. But instead of acknowledging the internal heterogeneity of migrant "communities" and questioning the horizontality of their relations, studies involving people who share a single ethnic or national identification gradually lost scholarly interest in favor of so-called nonethnic approaches (Glick Schiller et al. 2006; Carter and Fenton 2010).

Diversity studies form part of the so-called local turn which aims at comparing place-making involving migrants in urban contexts (Brettell 2003). The field of study is concerned with "understanding the modes 
and processes of social differentiation" (Vertovec 2015, 10). Within this framework, the focus lies on multi-group relations, that is, between people with a variety of ethnic, status, and gender identifications from different countries of origin (Vertovec 2007). As diversity and transnational interconnectivity characterizes today's societies of immigration, they offer insights into the social and administrative conditions to the construction of social cohesion in contemporary societies of immigration (Dobusch 2017; Nieswand 2017). Yet, their focus on the local and on non-ethnic approaches leads to leaving transnational interconnections largely out of the picture (Lamont et al. 2016, 287).

In sum, the commonality between the paradigm of internal horizontality and the paradigm of not-thinking-ethnicity is that they curb the study of social differentiation among migrants. The lack of interest in these dynamics, their historical depth, and their geographical scope, indirectly reifies migrants of the same ethnic or national origin as a homogenous group. Notwithstanding these general trends in research on transnational migration, there is evidence on how relations among migrants produce and engage with power and the experience of inequality. Most of the studies on internal relations explain hierarchical behavior either through social dynamics in the context of residence or in the context of origin. With regard to the society of residence, studies argue that specifically local conditions to incorporation contribute to "deep divides" (Ehrkamp 2006) between migrants. "Reactive ethnicity", that is, the (collective) exasperation of ethnic identifications as a means to differentiate from unmarked locals, can be a way to deal with ethnic, racial, or religious discrimination (Portes 1999; Çelik 2015). Intragroup Othering is yet another. According to Pyke and Dang (2003), the usage of categories such as "fresh of the boat" and "whitewashed" indicates that migrants internalize values that contribute to their own discrimination by the society of residence. Another strand of research relates the origins of these categories to the unequal relations engendered by different historical conditions of emigration, as well as to diverse political and socio-economic backgrounds in the country of origin (Kunz 1973; Charsley and Bolognani 2017; Su 2017). Yet, while both the context of residence and of origin are certainly crucial in shaping internal relations, considering 
one without the other offers only a partial analysis of the social dynamics at hand.

To gain greater insights into the historical depth and transnational scope of internal differentiation, this book examines it as an engagement with interconnecting hierarchical structures prevalent in the society of origin and of residence. Following Kelly and Lusis' (2006) work on the way evaluations of resources among Toronto-based Filipino-Canadians are informed by interrelating strands of transnational connectivity, I combine the study of local social differentiation with that of migrants' engagement in transnational social fields.

\section{Transnational Social Fields}

The so-called transnational turn represents another effort to overcome the limitation posed by methodological nationalism. Building on previous research on "transnational social spaces" (Pries 1996; Faist 1998), Peggy Levitt and Nina Glick Schiller (2004, 1015) suggest that, in order to understand migrants' sometimes contradictory social processes, we need to recognize that they "occupy different gender, racial, and class positions within different states at the same time". Drawing on Bourdieu's work on capital creation, they introduce the concept of the "transnational social field" (idem 2004, 1008f.). Since then, a growing body of research explores the transnational dimension of migrants' social mobility. These studies show that, as migrants engage in multiple local and transnational social fields, the positions they occupy in different contexts are interdependent and complementary (Nowicka 2013, 2014). In creating capital, different European case studies show that migrants rely on two types of resources whose availability is conditioned by gender, class, ability, or age identities: "location-specific capital", that is, locally relevant cultural and social capital (Nowicka 2013; Nohl et al. 2014; Cederberg 2015), and "migration-specific capital", which is created through resources that draw on migrants' racial, ethnic, and cultural identifications (Erel 2010). Thus, both location- and migration-specific resources are crucial in migrants' creation of capital. 
This literature has a tendency to assume that, through their capital creation, migrants challenge and transform hierarchal orders in the country of residence and of origin - an idea that reminds us of the paradigm of internal horizontality. However, the focus on migrants' capacities to transform societies entails the danger of sidelining individual difficulties and structural barriers migrants may meet in trying to create capital. It is thus useful to complement these studies with research that considers how past and present dynamics of colonialism, imperialism, capitalism, and nation-state policies shape migrants' self-perceptions and their image among locals (Henry 1999; Glick Schiller 2005). Aihwa Ong offers great insights into the ways migrants' strategies of creating capital respond to, and engage with negative stereotypes that draw on historically built international economic and political hierarchies (Ong 1992, 1996). Importantly, she observes that barriers to capital creation emerge "when there is a mismatch, from the hegemonic standpoint, between the symbolic capital and its embodiment" (idem 1999, 91). In other words, a resource may not be recognized as a capital if it is devaluated by the subjection of its holder to negatively charged social categories. In a similar vein, Anja Weiss shows that not only the identifications and categorization of its holder, but also the origin of the resource itself plays a role in its valorization (idem 2005, 717-22). We thus retain that migrants' strategies of capital creation navigate between individual dispositions and a variety of structural-even though to some extent variable and negotiable-constraints.

In short, research shows that the use of location- and migration-specific resources plays an important role in migrants' creation of capital, because their valuation is influenced by historically grown international social inequalities. Relations between people who are engaged in the same transnational social field reflect these inequalities. Strikingly, however, so far research on transnational social fields mostly traces unrelated individual migrants' trajectories, privileging the interest in migrants' agency in relations with the society of residence and of origin over local internal relations.

To summarize, dominant approaches to internal differentiation and transnational social fields, respectively, neglect the study of the transnational and the local dimension, which explains why we yet know relatively 
little about the way migrants engage with unequal relations across local and transnational social fields. The way I propose to address this issue is in combining both strands of research through their common theoretical background: Pierre Bourdieu's work on social fields and symbolic struggles over the definition of criteria of evaluation.

\section{Evaluation and Capital Creation Through Boundary Work}

Pierre Bourdieu's work certainly is one of the most substantial theoretical frameworks in the social sciences. Following Wacquant's suggestion (2018), I use it as a toolbox rather than applying it in its integrity. Bourdieu (1979) argues that processes of evaluation and judgment form the basis of social differentiation. These relational processes represent the expression of relations of power and inequality resulting from the uneven distribution of resources and from variations in their recognition as capital. They take place when agents use distinctive symbols or practices in order to sustain their struggle over the valorization of their resources as capital in a particular social field. Here, an agent's position is determined by his capital's relative volume and its composition compared to that of other agents. He defines a capital as a material or immaterial resource whose symbolic power is acknowledged in the social field in which it is employed. The three categories of capital are economic capital, which relies on financial assets or properties; cultural capital, which can be created through professional, practical, or cultural knowledge that may or may not be institutionalized; and social capital, which derives from meaningful or creative relationships (Bourdieu 1985, 724).

In this book, I refer to two authors whose work is a productive expansion of Bourdieu's approach to power and inequality: Michele Lamont's boundary approach and David Graeber's theory of value. The link between the three approaches is their focus on practices of evaluation within particular social fields.

The boundary approach traces the construction and deconstruction of social boundaries. Social boundaries are thereby defined as "objectified 
forms of social differences manifested in unequal access to and unequal distribution of resources (material and nonmaterial) and social opportunities" (Lamont and Molnár 2002, 168). The strength of this approach lies in its ability to reveal intersecting inequalities as it takes into account the usage of boundaries based on any socially and situationally relevant marker of difference. Moreover, the conceptualization of boundaries respects the fluctuant nature of structural constraints and the great importance of individual agency. In doing so, it offers an alternative view to a widely critiqued path-dependency in Bourdieu's conception of the interaction between structure and agency (Lahire 1999; Martuccelli 2006). In bringing together Bourdieu's concept of capital creation with the boundary approach, I understand the deconstruction of a boundary, in other words, inclusion, as the valorization of a resource as a capital. Vice versa, exclusion represents the denial of a resource's value, which is expressed in the construction of a social boundary. Tracing differential patterns of evaluation in boundary work is a tool to understand the way different systems of evaluation interrelate (Lamont 2012).

In his anthropological theory of value, David Graeber introduces an understanding of such systems of evaluation that goes beyond Bourdieu's relatively state-centered and static view. In Bourdieu's conception, agents' activities in a social field simultaneously exhibit and reproduce incorporated evaluation criteria which he calls classificatory schemes ${ }^{4}$ (Bourdieu 1979, 191). The attribution of worth through practices of differentiation does not only represent individual cognitive structures, but such criteria of evaluation reflect and engage with the dominant social structure (Wacquant 1992, 12f.). Accordingly, the symbolic struggle over the definition of these classificatory schemes is at the heart of power relations (Bourdieu 1985, 729). Graeber $(2001,115)$ agrees with Bourdieu in understanding struggles over the definition of structures of reference, but also their relation to one another, as the most crucial political project.

Despite the diverse theoretical origin of Bourdieu's and Graeber's $s^{5}$ work, their notions of classificatory schemes and systems of value converge

\footnotetext{
${ }^{4}$ Bourdieu uses the concept of habitus to explain these processes.

${ }^{5}$ Graeber builds on Marxist and Maussian thought, in which he follows the action-oriented anthropology of value in the tradition of the University of Chicago (Robbins and Sommerschuh 2016).
} 
in a crucial point. Following Bourdieu, mental structures incorporate social structures. According to Graeber $(2013$, 224) the worth that is given to an action or practices (its exchange value) mediates larger values, in the sense of "ideas about what is ultimately important in life". Using Graeber's vocabulary, criteria of evaluation reflect and engage with larger "systems of value". Thus, in combining Bourdieu's approach to power and inequality and Graeber's theory of value, I conceive the creation of economic, social, and cultural capital in boundary work as essentially geared toward to mediation of particular values within a prevailing system.

However, Bourdieu foregrounds the national homogeneity of classificatory schemes: systems of evaluation of all social fields embedded in one particular nation-state follow the same principles of division (Bourdieu $1997,98)$. Graeber $(2013,226)$, instead, suggests that in complex societies, a practice of evaluation is received in one or in several overlapping social fields (which he calls "social arenas"). Against Bourdieu, he sees social structure as inherently elusive, as it gets lost in the messiness of continuous social action, that is, its production and reproduction; social fields themselves are fragmented and ephemeral (Graeber 2001, 259ff.). Hence, the system of value by which one social field is shaped may or may not relate to those others in the same national context. Graeber's more versatile conceptualization of systems of value will be useful to complement Bourdieu's failure to theorize the interconnection between different social fields.

This book offers a fine-grained ethnography of the conditions and processes in which difference, in the form of social boundaries, is constructed and deconstructed in internal relations. How do these processes interact with the Iranians' opportunities and limitations to have their resources acknowledged as capital in social fields relative to the German or to the Iranian society? In tracing internal relations across a period stretching from the 1930s until today, I study how agents engage, through evaluation in boundary work, with diverse, partly competing systems of value that prevail in the different social fields. In doing so, I examine the role of systems of value as structures of reference in the interrelation between dynamics in local and transnational social fields.

Needless to say, if it comes to studying internal diversity as a factor influencing social cohesion in European societies, we could think of a 
great number of case studies. Similar dynamics to those this book will explore can certainly be found among other migrant groups. However, the historical depth and the geopolitical relevance of the presence of Iranians in Germany, more precisely, in the city of Hamburg, make it a particular case of study.

\section{Iranian Migration to Hamburg}

Iranians did not start to emigrate after the Islamic revolution in $1979 .^{6}$ Certainly, the events which led to the replacement of the Westernoriented Pahlavi monarchy by a republic based on the principles of Islam under Ayatollah Ruhollah Khomeini marked a turning point in these processes not only in terms of numbers, but also in terms of the diversity of emigrants' social profiles and their destinations. However, the territory of contemporary Iran has always been shaped by the fluctuation of people (Keddie and Matthee 2002; Daryaee et al. 2010; Dabashi 2016). Depending on the time of emigration, reasons for geographical mobility vary from economic motivations to studies, from flight of the Iran-Iraq war (1980-1988) and political persecution to social and family issues. Today, people identifying as Iranian are dispersed all over the world. They still live in some of the earliest places of settlement, that is, Iran's neighboring countries, the Persian Gulf region, and India, in Europe, and more recently in North America and Australia (Subrahmanyam 1992; Koser Akcapar 2006; McAuliffe 2008; Adelkhah 2012; Khosravi 2018). Finally, since the 1990s, Southeast Asia, in particular Japan and Malaysia, has become a destination of migration (Fozi 2013). Due to the great historical depth, coming with important generational variety, and the uneven quality of statistical data provided by the countries of residence, the quantity of Iranians living abroad can only be approximated to $4 \mathrm{mil}$ lion, which represents about $5 \%$ of the population of Iran (Vahabi 2012, 13). Currently, the most important places of settlement are the USA (with about 481,000 (Public Affairs Alliance of Iranian Americans 2014, 3)), Germany (197,000 (Statistisches Bundesamt 2017a)), Canada (about

\footnotetext{
${ }^{6}$ See timeline in the appendix.
} 
108,000 Iranian-born, (in UNICEF 2013, 2)), the UK (about 80,000 Iranian-born in 2014 (Office for National Statistics 2015)), and Sweden (about 65,000 Iranian-born in 2014 (Malek 2015, 87)).

Iranian migration to Hamburg, Germany's second largest city, dates back to the mid-nineteenth century, thanks to early trade agreements. Only the important waves of immigration that followed the Iranian revolution in 1979 diversified the movement along lines of class, gender, ethnicity, political orientations, and religious adherence (Hesse-Lehmann 1993). Today, more than 23,000 among the city's 2 million inhabitants are of Iranian origin (Statistisches Amt für Hamburg und SchleswigHolstein 2018, 7), constituting Europe's second largest Iranian population, and Hamburg's fifth important immigrant group. Through naturalizations, onward or return migration, and mixed marriages, ${ }^{7}$ the true number of people nourishing Iranian identifications is certainly much higher. Thus, as a city, Hamburg counts the largest number of Iranians in Germany, while it is the third federal state in numbers of Iranians after North Rhine-Westphalia and Lower Saxony (Statistisches Bundesamt 2017b, 128ff.).

Iran's place in the international political and economic landscapes, shaped through its Islamic government and its richness in natural resources, ${ }^{8}$ influences the lives of its emigrants. At present, it has the second largest economy in the Middle East, after Saudi Arabia, and, with about 80.6 million people (as of 2017), the second largest population after Egypt (The World Bank 2018). Since the revolution in 1979, the Islamic Republic constructs its political discourse on an opposition to the USA and Israel and, in its extreme, on a condemnation of anything associated with the West. Since the hostage of US-embassy staff in Tehran in 1979 , this political stance and Iran's pursuit of a contentious nuclear program has seen the country repeatedly subjected to partly severe economic sanctions both from individual nation-states and international organizations. Within Iran, the revolution, the war with Iraq, and a neoliberal economy under sanctions fostered the development of tangled, competing

\footnotetext{
${ }^{7}$ Until October 2019, when Iranian legislation changed, children of a foreign father and an Iranian mother were not eligible for Iranian citizenship.

${ }^{8}$ According to the World Bank (2018), "Iran ranks second in the world in natural gas reserves and fourth in proven crude oil reserves."
} 
political and economic power structures (Therme 2013). In the face of internal and external restrictions to the participation of people living in Iran in global cultural and economic flows (Appadurai 1990), its migrants have come to play an important role, acting as intermediaries for the circulation of ideas, practices, and goods between Iran and the West (Azadarmaki and Bahar 2007; Sreberny-Mohammadi 2013; Moghaddari 2015). This is even more significant, as the large portion of Iranians — at least those who go to Western countries — are not classical labor migrants; in Germany, they are typically characterized (and like to characterize themselves) as being one of the immigrant populations with the highest average level of education' (see also Bozorgmehr and Sabagh 1988; Sadeghi 2015). As this book will show, the particular place of Iran in the global political and economic landscape, power constellations in Iran, and the average educational level of Iranian migrants shape their conditions for capital creation in the place of residence.

Since the Islamic revolution in 1979, social scientists have produced a substantial body of qualitative research on Iranian migration, to which three critical remarks are at order. First, studies carried out in diverse countries of residence at different points in time observed a strong tendency toward social differentiation between Iranians (Kamalkhani 1988; Bozorgmehr et al. 1993; McAuliffe 2007; Khosravi 2018). However, schemes of social differentiation are often drawn along emic markers such as ethnicity and religion, generation (Chaichian 1997; Daha 2011), "vintages" 10 of migrants, political convictions (Nassehi-Behnam 1991), and class (Bozorgmehr and Sabagh 1988; McAuliffe 2008). If we understand these labels as "categories of practice" (Brubaker and Cooper 2000, 4ff.) rather than as analytical instruments, such constructions of difference appear much more flexible and versatile. Second, as I showed earlier, inequalities related to Iran cannot be understood without taking into account their linkages with inequalities in the country of residence. Maybe because of the practicalities and risks of doing research in Iran (Nadjmabadi 2009), transnational dynamics have not yet received

\footnotetext{
${ }^{9}$ In an OECD report (OECD-UNDESA 2013, 6), half of the 845,000 Iranian-born adults living in member countries in 2011 are qualified as high educated.

${ }^{10}$ I understand "vintages" of migrants with Kunz (1973) as people who move for similar reasons at the same period of time (see Chap. 3).
} 
enough consideration in the study of Iranian migration. Third, much of the research on Iranian migrants' identifications centers on the USA and Canada (Mobasher 2006; Alinejad 2013; Maghbouleh 2017; Malek 2019), while there is a need for more research on these negotiations in the European context. Despite Germany's historical importance as a country of destination and the large number of residents of Iranian origin, there are few empirical studies providing consistent material for comparison (see Sanadjian 1995; Sadeghi 2018a, b). This book contributes to a more complex understanding of Iranian migration, tracing the fluidity of social boundaries and the transnational dimensions of local inequalities.

Since 2012, the Federal Republic of Germany (FRG) receives, with 20-50\%, the biggest share of asylum requests in the European Union (Migration Policy Institute 2018). Nevertheless, the society only awoke to the fact that it had become a country of immigration at the turn of the twenty-first century. At about the time, the national economy began its growth rate that made it one of the world's leading economic and political powers today.

Just like in all Western European countries, the history of mass immigration to Germany started after World War II (WWII) ${ }^{11}$ (Castles et al. 2013, 102-26). In contrast to other important European countries of immigration, however, Germany does not have a prolonged colonial past. Thus, most people who came to Germany from the mid-1950s were not former colonial subjects, but "guest workers" (Gastarbeiter) mostly of Italian, Spanish, Turkish, and Yugoslavian origin, called upon to provide manpower for the thriving German economy (Göktürk et al. 2007, 9ff.; Messina 2007, 124f.). This immigration was conceived of as being temporary: work and residence permits were only granted for restricted periods, family reunification was discouraged, and programs to facilitate insertion were largely directed toward their orientation in the job market (Castles et al. 2013, 107). From the recruitment ban for labor migrants in 1973 onward, immigration policies became ever more restrictive. Instead of diminishing the movement, this change led a growing number of migrants to try to obtain a residence permit via the asylum procedure in the following decades. While immigration became durable regardless

${ }^{11}$ These were previously rather countries of emigration. 
of policy changes, politicians continued to deny this reality (Aumüller 2009, 195). Significantly, in 1991, the then-chancellor Helmut Kohl stated "we [...] have to be conscious about the fact that we cannot admit all those who want to come. The Federal Republic of Germany is not a country of immigration" (Kohl 1991). Uncertainty and unemployment after the German reunification in 1990 fostered xenophobia and racist thought and urged politicians to implement a more restrictive legislation in order to decrease the number of asylum seekers (Messina 2007, 127ff.; El-Tayeb 2016, 143ff.; Mushaben 2017).

It was only at the turn of the century that more and more voices brought the culturally heterogeneous reality to the public debate, even though they were forcefully countered by anti-immigration discourses that did not originate exclusively from the social margins. ${ }^{12}$ The approach to immigration shifted from differentialism to assimilationism (Brubaker 2001). Within this new conception, education, occupational achievements, and, importantly, resources conceived as Germany-specific, ${ }^{13}$ such as language skills and cultural knowledge, are seen as criteria for successful integration (Bail 2008, 49). Comprehensive federal programs promoting integration were developed, which, however, lay the responsibility for assimilation on the migrants (Aumüller 2009, 199f.). Research on interactions between Germans and people of foreign origin shows that migrants', their children's and even grandchildren's chances to generate capital in Germany are restricted by their construction as cultural or racial Other (Weiss 2001; Sökefeld 2004; Terkessidis 2004; Ehrkamp 2006; Gruner 2010; Marschke and Brinkmann 2015). At least since alQaida's attacks in the USA of September 11, 2001, Islamophobia has become one of the main vehicles for racial and cultural discrimination in Europe (Fekete 2004; Shooman 2014; De Genova 2017). In Germany, strong anti-immigration and anti-Muslim resentments are represented in movements such as Pegida (Patriotic Europeans Against the Islamization

\footnotetext{
${ }^{12}$ One example is the Social-Democratic Party (SPD) politician Thilo Sarrazin, whose book "Germany abolishes itself" (2010) caused a huge public debate, and was sold in over 1,3 million copies (cro 2012).

${ }^{13}$ I use the notion of "Iran- and Germany-specific resources" to designate assets which are, in a specific social interaction, conceived of as being created in or representative of identifications related to these national contexts.
} 
of the West, initiated in late 2014) and the increasingly popular rightwing nationalist party AfD (Alternative for Germany), founded in 2013.

The crisis of the European border regime in the context of the movement of people by the thousands through the Mediterranean and the Balkans that began in 2015 eventually challenged the prevailing discourse on immigration. In June 2015, chancellor Angela Merkel stated for the first time that "we are after all already a country of immigration" (dpa 2015). In that year, 434,750 first asylum requests were filed in Germanymore than 3 times the number of the preceding year and 15 times as much as in the year 2008 (Bundesamt für Migration und Flüchtlinge 2016, 3). Within the government-promoted, but highly controversial, "Welcome culture" (Willkommenskultur) (Vollmer and Karakayali 2018), not only Germans but also already established migrants mobilize or become mobilized as benefactors, mediators, spokespersons, and critiques of the newly arrived (Karakayali and Kleist 2015). These developments make Germany an important place to study the stakes of transnational migration and the internal construction and deconstruction of difference today.

The fluctuation of people between Germany and Iran goes back to the Middle Ages, when merchants, soldiers, and political dignitaries began to travel between the Habsburg Empire and Iran (Kochwasser 1961, 28ff.). The contemporary conditions of Iranian immigration to Germany are structured by political and economic collaboration between the two countries throughout most of the twentieth century until today (Adli 1960; Khatib-Shahidi 2013). Moreover, in contrast to North American countries of destination where Iranians can only enter after gaining a green card, due to its geographical proximity, Iranian migration to Germany passes through both regular and irregular entry and the asylum procedure (Hesse-Lehmann 1993). In the course of the so-called refugee crisis in 2015, Iranian asylum applications in Germany reached peaks that exceeded the post-2009-anti-election protests in numbers of applications (Bundesamt für Migration und Flüchtlinge 2017, 21). As a matter of fact, in the past ten years ${ }^{14}$ Iranians figure among the ten largest groups

\footnotetext{
${ }^{14}$ Except for the years 2014 and 2015, as numbers of asylum requests from other nationalities skyrocketed.
} 
of asylum seekers in Germany (Bundesamt für Migration und Flüchtlinge 2016, 8), alongside other forms of entry such as through student visas. Over the past 20 years, several people of Iranian origin have reached important levels of public renown. They include the federal politicians Sahra Wagenknecht (die Linke), Omid Nouripour (Alliance '90/the Greens), actress Yasmin Tabatabai, journalist Bahman Nirumand, architect Hadi Teherani, composer Ramin Djawadi, artist Parastou Forouhar, and the footballer Ali Daei-to name but a few.

In sum, at a time in which Germany experiences a turning point in its history of immigration, studying the shifting reception of Iranians, most of whom have a Muslim background, over more than 80 years and their engagement with these changing conditions in internal relations offers crucial insights on the future stakes of recent influxes. The way migrants negotiate between different systems of value in processes of boundary work allows us to understand transversal social dynamics in one of Europe's major countries of immigration.

\section{Fieldwork}

According to the German poet Hermann Hesse (1999 [1923], 123), "the things we see $[\ldots]$ are the same things that are within us". Experiences of community and conflict in Iranian-German contexts and of cultural and racial Othering in contact with Germans stimulated my interest in studying internal diversity. I am the child of an Iranian-German binational couple and that I grew up in a small rural town at the coast of the North Sea, which is a one-and-a-half-hour-drive north of Hamburg. More particularly, I grew up between a largely migrant-less everyday life and regular get-togethers with some of the few local Iranian families. Every few years we spent our holidays in Babol—my second place of origin. Episodes of racism I experienced myself or I witnessed my father experiencing marked me. These experiences also informed my relations in the field and the way I interpret ethnographic data.

This book is based on material I raised through nine months of ethnographic fieldwork in Hamburg between March 2013 and April 2014. However, rather than being single-sited in the "classical" way, it was a 
"strategically situated ethnography", that is, there was a "sensed, partially articulated awareness of specific other sites and agents to which particular subjects have (not always tangible) relationships" (Marcus 1995, 111). Hence, between 2012 and 2016, the research followed me during my temporary stays in Iran-I spent a total of three months in Tehran, Babol, a city in the north of Iran, and Mashhad-and in Geneva, where I was based.

Life experiences as a "halfie" (Abu-Lughod 1991) in itself does not say much about the level of my personal involvement and the relations that I developed with my interlocutors (Narayan 1993). In researching differentiation, I am necessarily involved in its relationality. The following vignettes both introduce my ethnographic methods, illustrate my relational approach to ethnography (Desmond 2014), and offer insights into questions of my own positionality, research ethics, and political issues in encounters with my interlocutors.

In anthropology, participant observation remains a crucial methodand so it was in this research. More than that, I voluntarily, and sometimes also involuntarily, became an observing participant. For instance, I worked as a waitress in a local Iranian restaurant for six weeks, I participated in the organization of two cultural festivals (see Chaps. 3 and 5), and engaged in several research vulgarization activities on the invitation of different interlocutors. Several times, interlocutors accompanied me to field sites (for instance to meet a person that could have known a deceased parent) thus directly and indirectly prompting me to confront my perceptions and interpretations with theirs. I also spent free time with people I met in the field and who later became research participants. It is through such long-term relations that I understood my role in the construction of social boundaries.

On a warm summer evening in 2013, for instance, I joined Babak, Yara, and a few other friends at the Schanzenviertel, a recently gentrified district popular with young professionals and leftist activists. It is a quarter of town where I lived before, where I felt at home. We made a barbecue in a park and then walked round the lively streets. I knew these people since a few months already. Certainly, it helped that I could participate, despite with less fluency, in their discussions in Persian. We wanted to go somewhere together, but we still hadn't decided on a destination. After a 
while, I got tired of purposelessly standing on the street. I wanted to suggest we join some friends of mine. "Okay, what should we do now?" I asked. Babak laughed "You are such a potato (sibzamini)! So funny. I have no idea, nobody cares, we just hang out here." "Potato" is an expression popular among migrant youth to designate Germans. Babak had called me that way before and he had told me that it was meant as a joke. Yet, even if it was effective just for a few minutes, Babak created a boundary between me and the group. He interpreted my impatience as a Germanyspecific resource and did not acknowledge it as a capital. Incidentally, four months later, I told him that I was tired of him repeatedly identifying me as a German. "But you are German!" he said again. Then again, on the next Iranian new year, he invited me to a party at his place. When I asked if I could bring a Belgian friend, he said "I am sorry but I would like us to be only among ourselves." Who did he mean by that this time? At the party, all guests were Persian speakers and his acquaintances.

But let me finish the story of the summer evening: just an hour after Babak's boundary-making, Yara invited me to a high-end bar. While she included me, she managed to discreetly leave behind the others including her close friend Yalda whose new German boyfriend had just joined us. When we arrived there, I realized that Yara wanted to meet a new lover, the bar's Iranian owner. I was a female of her age and unaccompaniedprobably the most suitable company of the group in this case. Thus, in my relations with interlocutors, I noticed how we used a variety of markers of difference to create boundaries that drew us together or created distance depending on the situations and the moments in the evolution of our acquaintance.

It is in observing the way my self-claimed and attributed identities shifted and how my resources were valorized differently in different social context (also compared to those of my interlocutors) that I understood the importance of taking situations as units of analysis (Eckert 2016). To account, against Bourdieu, for the complexity of individual situations and trajectories (Martuccelli 2009), I thus approach the production of difference through "ethnographies of the particular" (Abu-Lughod 1991, 148ff.).

Interviews were a crucial part of my research, but while I carried out a small number of formal interviews, most occurred spontaneously and in 
informal context. Some interviews were directed toward exploring the past rather than the present, relating oral history, while others narrated life courses. An issue that was omnipresent in this research, but that was particularly noticeable in conversations, was the concern with political position-taking, and, in as far as they may be interpreted as connected, with religious beliefs. There is little anthropological research carried out in Iran today, which is largely due to the Iranian state controlling access and publications (Nadjmabadi 2009; Khosravi 2017). Within the past decade, many researchers, mostly those with Iranian citizenship, have been detained in the country. Many non-citizen researchers have been denied entry or research permits. This is why my research in Iran was completely informal. However, even in researching Iranian migration in Hamburg, avoiding political risks for both my interlocutors and myself is a primary concern. This is a particularly acute concern in this city as there is a strong presence of Iranian state institutions: the Consulate General, a school for Iranian expats, an office of the Iranian national bank, and the Imam Ali mosque. Moreover, many local Iranians told me that they were suspicious of being spied on by peers.

The concern for my interlocutors and my own political safety shaped my fieldwork encounters. I particularly remember the one interview with a clerk of the Imam Ali mosque. I met Mr. Saidi once when I visited the mosque. However, it took months of negotiations and several refusals from his part before I could send him a list of questions and he agreed to the interview. Mr. Saidi must be around 60 years old, but his hair is completely white. Although he has a limp, he walks straight and exudes dignity. It is a Friday afternoon and I follow him through the building, in which he opens doors to look for an empty room. Later, he told me that he chose that day of the week because he knew the place would be empty. Finally, we stay in the library hall. He lays my printed questions with written notes in Persian on the sides in front of him- he was clearly cautious. Although I planned to be equally careful not to express any political or religious opinion in my questions and in my demeanor-I wore the veil-our conversation, in German, starts off with hitting a taboo. "Since when do you know Hamburg and the Imam Ali mosque?" "Since 1982." "What do you mean? Is it since 1982 that you live in Hamburg, or that you work at the mosque?" "Neither." He explained me his 
professional and migratory trajectory prior to 1987, then he adds "but you should not mention this!" (field notes October 2013). Moreover, during the interview, my headscarf fell off several times. Every time it took a minute before I noticed it. He never even twitched his eye. In the end, he told me a secret which he also insisted I should not write about. In doing so, he presented himself as having a critical distance to the ideology of the Iranian government.

Just like Mr. Saidi, interlocutors shared political opinions or a personal history of confrontations with Iranian authorities with me. It was only those who were sure never to return to Iran who did so without reminding me that I should not write about this. Some interlocutors also chose not to tell me certain relevant personal matters. In many cases, when people withheld information, they did so in an attempt to influence my image of them and the way I represent them in my research. More often than not, these matters reveal the way my interlocutors engage with the historically situated experience of inequality. They form, as the "unknown known" (I know it but I behave as if I do not) or the partly "unknown unknown" (I just don't know or I guess there might be more to it but I do not ask) (Žižek 2004), a ghostly presence in this book (Gordon 1997; Cabot 2016). Human beings are complex. Persian vocabulary has a word for the protection of the space for the unknown in our complex personhood: ta'ârof (Vivier-Muresan 2006). Relating to Islam, it serves to preserve a person's honor (âb'e ruh) in social interactions. ${ }^{15} \mathrm{It}$ is a concept I strive to respect both in fieldwork and in writing. As far as I can sense it, this (un)knowledge informs my analysis. In this book, I mostly strive to respect the cover of the unknown and write around it.

Following Ann Stoler (2009) in reading "along the archival grain" is one way to study the ghostly-because tabooed or untold—stories of power inequality through written policy documentation (Vaught and Orum Hernández 2017). Reading along the archival grain consists on taking the archives as a site of ethnography rather than using archival documents as counterweights to the stories of the people (colonial) states govern. It means studying archival production on its own behalf, as a

\footnotetext{
${ }^{15}$ Tellingly, a religious saying goes "cover the believers' failures, as god forgives all failures a thousand times" (pushândeye oyub-e mómenân bashin ke khodâvand satârâloyub ast).
} 
technology of rule, by reading "for its regularities, for its logics of recall, for its densities and distributions, for its consistencies and misinformation, omission and mistake" (Stoler 2009, 100). More generally, my writing an historically informed anthropology is motivated by the aim to complement Western historicity which tends to deny its "Others" a past of similar complexity as their own, and thus reproduces unequal power relations (Said 1978; Wolf 1982; Chakrabarty 2000). My interest is exploring how contemporary internal differentiation relates to local and transnational dynamics that shaped relations among Iranian migrants in the past. For all these reasons I studied the Hamburg government's internal communication and correspondence with local Iranians as well as Iranian immigration-related newspaper documentation at the city's archives, Staatsarchiv Hamburg (STAHH). These documents cover a period from 1857 until the 1980s.

The archives entertain a close relationship to the present. I could observe it when Karim, a barista in his early thirties, asked me if he could come with me. The tall man stands out by a dense black beard and long hair. He never went to college, but he said that he was curious about history. The lady at the entry studied him closely, suspiciously, when she asked him to sign the usual documents. As we looked through the archival files, a signature saying "Heil Hitler" caught our attention. Karim's first reaction was to raise my attention to the fact that the small cell that we occupied had no direct windows to the exterior and that there could be gas streaming through the ventilation system. "Everywhere I go, I first check possible escape routes. My father taught me this" (field notes June 2013). His sense of threat together with my own trepidation which were provoked by the Nazi salutation made me shiver.

Finally, I used document and media analysis (newspaper articles, leaflets, private photos, videos, TV documentation) in order to cross and complement ethnographic data (Image 1.1). Media procuration and visioning were also sometimes integrated in relational dynamics. I obtained some of the most interesting pictures and movies through Parviz. The former carpet shop owner, in good shape despite being in his eighties, invited me to his home and enjoyed spending afternoons with me, scanning through his vast music and video archive together. He was more patient than me I admit. In the end, he handed me a DVD with a 


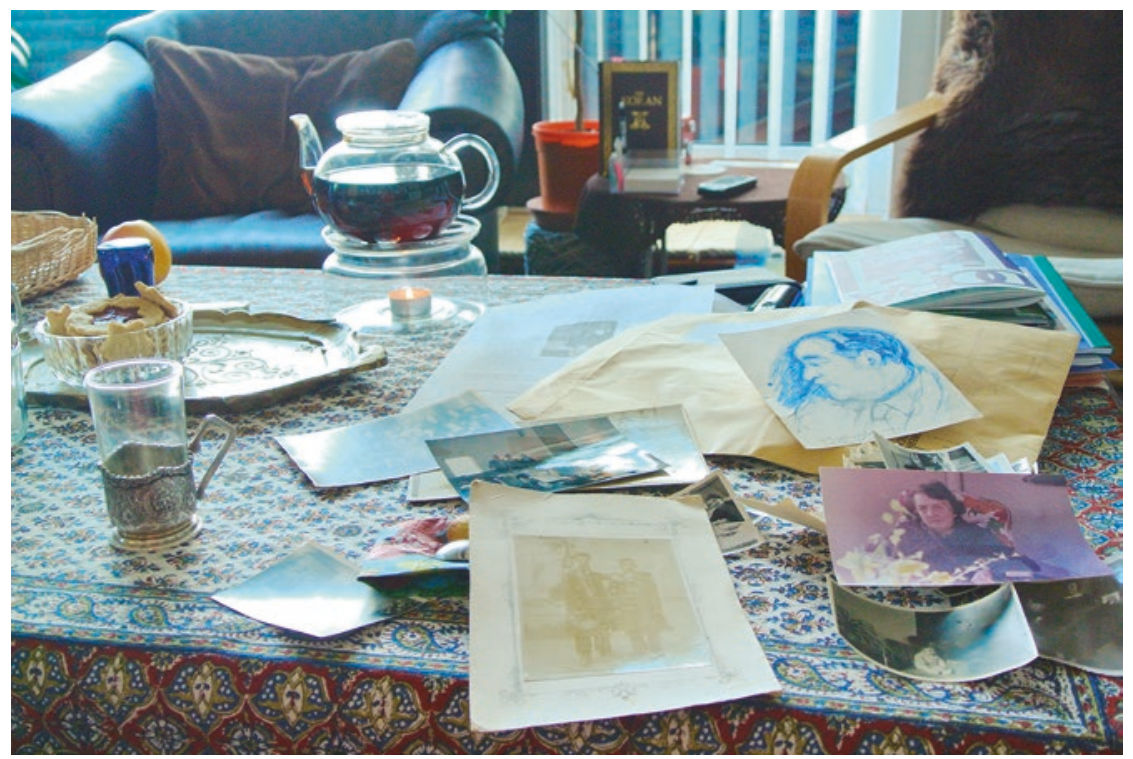

Image 1.1 Black tea, a tablecloth from Iran and a part of Siavash's family archives at his home. (July 2013, author's photo)

personal selection and one video struck me in particular: shot with an amateur camera in the 1990s, it showed the flat, green, northern German landscape passing before the front window of a Mercedes Benz while the tape recorder played Iranian classical music.

\section{The Structure of This Book}

This book is a knitwork between fine-grained narratives taking the reader ever more deeply into the complexities of the social construction of diversity among Hamburg's Iranians and how it relates to their chances and difficulties to create capital in different social fields. The four first chapters are "paired", with each pair looking at social dynamics which involve two occupational groups who entertain transnational relations.

Chapters 2 and 3 examine the ways import-export entrepreneurs negotiate their presence in Hamburg - a discussion that simultaneously traces 
in the history of Iranian migration to the port city. Chapter 2 investigates how Ali and Jalal, two early Iranian merchants who came to Hamburg in the 1930s, mobilized kin to generate capital along the lines of generation, gender, and age and how this affects the way their children engage with other Iranians today. Chapter 3 reconstructs, through archival documents and historic accounts, how Iranian carpet merchants' collective identitary narrative became motivated by shared politics of value that engaged with changing systems of value in three local and transnational social fields over more than 60 years.

Chapters 4 and 5, in turn, concern contemporary dynamics and examine the individual trajectories and interactions among artists and people who consider themselves in connection to the world of art. Chapter 4 looks at the creation of collective identifications from an in-group perspective, that is, through the analysis of processes of inclusion and exclusion of different people in the cultural association Golestan. It illustrates what it means to claim culturally pluralistic identifications in the system of value that shapes the German public sphere and sees national identifications as mutually exclusive. Conversely, in Chap. 5, I take an intrarelational perspective to examine how boundary-making between three film professionals relates to their politics of value and barriers to their capital creation in different social fields.

Chapter 6 offers, in the examination of social interactions around the organization of an Iranian cultural festival, a context in which different agents that appeared in previous chapters interact. The juxtaposition of the different ways interlocutors engaged with the festival's organizer Behruz allows me to show how social differentiation among Iranians in Hamburg engages with multiple, contradictory systems of value.

In the conclusion I stress that migrants are active agents, who, depending on their personal trajectories, interests, and engagements, juggle resources to negotiate barriers to their capital creation in ephemeral, situational, often contradictory, and not always conscious ways in order to navigate swiftly vanishing and appearing chances and barriers to their generation of capital. Studying internal diversity, I argue, is showing how migrants are active agents in local and transnational relations that contest, evade, reproduce, and produce inequality. 


\section{References}

Abu-Lughod, Lila. 1991. Writing Against Culture. In Recapturing Anthropology: Working in the Present, ed. Richard G. Fox, 137-162. Santa Fe: School of American Research Press.

Adelkhah, Fariba. 2012. Les Mille et Une' Frontières de l'Iran: Quand Les Voyages Forment La Nation. Paris: Karthala.

Adli, Abolfazl. 1960. Außenhandel Und Außenwirtschaftspolitik Des Iran. Berlin: Duncker \& Humblot.

Alinejad, Donya. 2013. Locating Home in a 'Digital Age': An Ethnographic Case Study of Second-Generation Iranian Americans in LA and Their Use of Internet Media. Iranian Studies 46 (1): 95-113. https://doi.org/10.1080/00 210862.2012.743309.

Appadurai, Arjun. 1990. Disjuncture and Difference in the Global Cultural Economy. Theory, Culture \& Society 7 (2): 295-310.

Aumüller, Jutta. 2009. Assimilation: Kontroversen um ein migrationspolitisches Konzept, Kultur und soziale Praxis. Bielefeld: transcript Verlag.

Azadarmaki, Taghi, and Mehri Bahar. 2007. Emigration and Sociocultural Change in Iran. In The Cultures of Economic Migration. International Perspectives, ed. Suman Gupta and Tope Omoniyi, 143-158. Burlington/ Hampshire: Ashgate.

Bail, Christopher A. 2008. The Configuration of Symbolic Boundaries Against Immigrants in Europe. American Sociological Review 73 (1): 37-59.

Bourdieu, Pierre. 1979. La Distinction. Critique Sociale Du Jugement. Paris: Editions de Minuit. 1985. The Social Space and the Genesis of Groups. Theory and Society 14 (6): 723-744. https://doi.org/10.2307/657373.

\section{— 1997. Méditations Pascaliennes. Paris: Le Seuil.}

Bourdieu, Pierre, and Loïc Wacquant. 1992. The Purpose of Reflexive Sociology (the Chicago Workshop). In An Invitation to Reflexive Sociology, ed. Pierre Bourdieu and Loïc Wacquant, 61-216. Cambridge/Oxford: Polity Press.

Bozorgmehr, Mehdi, and Georges Sabagh. 1988. High Status Immigrants: A Statistical Profile of Iranians in the United States. Iranian Studies 21 (3/4): 5-36.

Bozorgmehr, Mehdi, Georges Sabagh, and Claudia Der-Martirosian. 1993. Beyond Nationality: Religio-Ethnic Diversity. In Irangeles: Iranians in Los Angeles, ed. Ron Kelley, Jonathan Friedlander, and Anita Colby, 59-80. Berkeley/Los Angeles/Oxford: University of California Press. 
Brettell, Caroline B. 2003. Bringing the City Back in: Cities as Contexts for Immigrant Incorporation. In American Arrivals: Anthropology Engages the New Immigration, ed. Nancy Foner, 163-196. Santa Fe: School of American Research Press.

Brubaker, Rogers. 2001. The Return of Assimilation? Changing Perspectives on Immigration and Its Sequels in France, Germany, and the United States. Ethnic and Racial Studies 24 (4): 531-548. https://doi.org/10.1080/ 01419870120049770.

. 2002. Ethnicity Without Groups. European Journal of Sociology 43 (2): 163-189. https://doi.org/10.1017/S0003975602001066.

Brubaker, Rogers, and Frederick Cooper. 2000. Beyond 'Identity'. Theory and Society 29 (1): 1-47. https://doi.org/10.1023/A:1007068714468.

Bundesamt für Migration und Flüchtlinge. 2016. Aktuelle Zahlen zu Asyl: Ausgabe Januar 2016. Government. Bundesamt für Migration und Flüchtlinge. http://www.bamf.de/SharedDocs/Anlagen/DE/Downloads/Infothek/ Statistik/Asyl/aktuelle-zahlen-zu-asyl-januar-2016.pdf?_blob=publicationFile 2017. Das Bundesamt in Zahlen 2017: Asyl, Migration und Integration. Bundesamt für Migration und Flüchtlinge. http://www.bamf.de/SharedDocs/ Anlagen/DE/Publikationen/Broschueren/bundesamt-in-zahlen-2017. pdf?_blob=publicationFile

Cabot, Heath. 2016. 'Refugee Voices': Tragedy, Ghosts, and the Anthropology of Not Knowing. Journal of Contemporary Ethnography 45 (6): 645-672. https://doi.org/10.1177/0891241615625567.

Carter, Bob, and Steve Fenton. 2010. Not Thinking Ethnicity: A Critique of the Ethnicity Paradigm in an Over-Ethnicised Sociology. Journal for the Theory of Social Behaviour 40 (1): 1-18. https://doi.org/10.1111/j.1468-5914. 2009.00420.x.

Castles, Stephen, Hein de Haas, and Mark J. Miller. 2013. The Age of Migration:

International Population Movements in the Modern World. New York: Palgrave Macmillan.

Cederberg, Maja. 2015. Embodied Cultural Capital and the Study of Ethnic Inequalities. In Migrant Capital: Networks, Identities and Strategies, Migration, Diasporas and Citizenship, ed. Louise Ryan, Umut Erel, and Alessio D’Angelo, 33-47. Hampshire/New York: Palgrave Macmillan.

Çelik, Çetin. 2015. 'Having a German Passport Will Not Make Me German': Reactive Ethnicity and Oppositional Identity Among Disadvantaged Male Turkish Second-Generation Youth in Germany. Ethnic and Racial Studies 38 (9): 1646-1662. https://doi.org/10.1080/01419870.2015.1018298. 
Chaichian, Mohammad. 1997. First Generation Iranians and the Question of Cultural Identity: The Case of Iowa. International Migration Review 31 (3): 612-627.

Chakrabarty, Dipesh. 2000. Provincializing Europe: Postcolonial Thought and Historical Difference. Princeton/Woodstock: Princeton University Press.

Charsley, Katharine A.H., and Marta Bolognani. 2017. Being a Freshie Is (Not) Cool: Stigma, Capital and Disgust in British Pakistani Stereotypes of New Subcontinental Migrants. Ethnic and Racial Studies 40 (1): 43-62. https:// doi.org/10.1080/01419870.2016.1145713.

cro. 2012. Sarrazin Strikes Again: German Author Says Berlin Is Hostage to Holocaust in Euro Crisis. Der Spiegel, May. http://www.spiegel.de/international/europe/controversial-german-author-thilo-sarrazin-launches-bookon-euro-crisis-a-834459.html

Dabashi, Hamid. 2016. Iran Without Borders: Towards a Critique of the Postcolonial Nation. London/New York: Verso.

Daha, Maryam. 2011. Contextual Factors Contributing to Ethnic Identity Development of Second-Generation Iranian American Adolescents. Journal of Adolescent Research 26 (5): 543-569. https://doi.org/10.1177/ 0743558411402335.

Daryaee, Touraj, Khodadad Rezakhani, and Matteo Compareti. 2010. Iranians on the Silk Road: Merchants, Kingdoms and Religions. Santa Monica: Afshar Publishing.

De Genova, Nicholas. 2017. The 'Migrant Crisis' as Racial Crisis: Do Black Lives Matter in Europe? Ethnic and Racial Studies 41: 1-18. https://doi.org/ 10.1080/01419870.2017.1361543.

Desmond, Matthew. 2014. Relational Ethnography. Theory and Society 43 (5): 547-579. https://doi.org/10.1007/s11186-014-9232-5.

Dobusch, Laura. 2017. Diversity Discourses and the Articulation of Discrimination: The Case of Public Organisations. Journal of Ethnic and Migration Studies 43 (10): 1644-1661. https://doi.org/10.1080/1369183X. 2017.1293590.

dpa. 2015. Merkel sieht Deutschland als Einwanderungsland - Angebote an Afrika. Süddeutsche Zeitung, June 1. http://www.sueddeutsche.de/news/politik/bundesregierung-merkel-sieht-deutschland-als-einwanderungsland\%2D\%2D-angebote-an-afrika-dpa.urn-newsml-dpa-com-20090101150601-99-07884

Eckert, Julia. 2016. Beyond Agatha Christie: Relationality and Critique in Anthropological Theory. Anthropological Theory 16 (2-3): 241-248. https:// doi.org/10.1177/1463499616662574. 
Ehrkamp, Patricia. 2006. 'We Turks Are No Germans': Assimilation Discourses and the Dialectical Construction of Identities in Germany. Environment and Planning A 38 (9): 1673-1692. https://doi.org/10.1068/a38148.

El-Tayeb, Fatima. 2016. Undeutsch: Die Konstruktion des Anderen in der postmigrantischen Gesellschaft. Bielefeld: transcript Verlag.

Erel, Umut. 2010. Migrating Cultural Capital: Bourdieu in Migration Studies. Sociology 44 (4): 642-660. https://doi.org/10.1177/0038038510369363.

Faist, Thomas. 1998. Transnational Social Spaces out of International Migration: Evolution, Significance and Future Prospects. European Journal of Sociology 39 (2): 213-248.

Fekete, Liz. 2004. Anti-Muslim Racism and the European Security State. Race \& Class 46 (1): 3-29. https://doi.org/10.1177/0306396804045512.

Fozi, Navid. 2013. The Iranian Diaspora in Malaysia: Emergent Pluralism. Middle EastInstitute. http://www.mei.edu/content/iranian-diaspora-malaysiaemergent-pluralism

Glick Schiller, Nina. 2005. Transnational Social Fields and Imperialism: Bringing a Theory of Power to Transnational Studies. Anthropological Theory 5 (4): 439-461. https://doi.org/10.1177/1463499605059231.

Glick Schiller, Nina, Linda Basch, and Cristina Szanton-Blanc. 1997. From Immigrant to Transmigrant: Theorizing Transnational Migration. In Transnationale Migration, Soziale Welt, ed. Ludger Pries, vol. 12, 121-140. Baden-Baden: Nomos Verlagsgesellschaft.

Glick Schiller, Nina, Ayşe Çağlar, and Thaddeus C. Guldbrandsen. 2006. Beyond the Ethnic Lens: Locality, Globality, and Born-Again Incorporation. American Ethnologist 33 (4): 612-633. https://doi.org/10.1525/ae.2006.33.4.612.

Göktürk, Deniz, David Gramling, and Anton Kaes. 2007. Germany in Transit: Nation and Migration 1955-2005. Berkeley/Los Angeles/London: University of California Press.

Gordon, Avery. 1997. Ghostly Matters: Haunting and the Sociological Imagination, G - Reference, Information and Interdisciplinary Subjects Series. Minneapolis/London: University of Minnesota Press.

Graeber, David. 2001. Toward an Anthropological Theory of Value: The False Coin of Our Own Dreams. Hampshire: Palgrave Macmillan.

- 2013. It Is Value That Brings Universes into Being. HAU: Journal of Ethnographic Theory 3 (2): 219-243. https://doi.org/10.14318/hau3.2.012.

Gruner, Sabine. 2010. 'The Others Don't Want ...'. Small-Scale Segregation: Hegemonic Public Discourses and Racial Boundaries in German Neighbourhoods. Journal of Ethnic and Migration Studies 36 (2): 275-292. https://doi.org/10.1080/13691830903387402. 
Henry, Sheila E. 1999. Ethnic Identity, Nationalism, and International Stratification: The Case of the African American. Journal of Black Studies 29 (3): 438-454.

Hesse, Hermann. 1999. Demian, Harper Perennial Modern Classics. New York: HarperCollins.

Hesse-Lehmann, Karin. 1993. Iraner in Hamburg: Verhaltensmuster Im Kulturkontakt, Lebensformen. Berlin/Hamburg: Dietrich Reimer Verlag. Jäckle, Sebastian, and Pascal D. König. 2017. The Dark Side of the German 'Welcome Culture': Investigating the Causes Behind Attacks on Refugees in 2015. West European Politics 40 (2): 223-251. https://doi.org/10.1080/0140 2382.2016.1215614.

Kamalkhani, Zahra. 1988. Iranian Immigrants and Refugees in Norway. Bergen: University of Bergen.

Karakayali, Serhat, and Olaf Kleist. 2015. EFA-Studie: Strukturen Und Motive Der Ehrenamtlichen Flüchtlingsarbeit (EFA) in Deutschland. Berliner Institut für empirische Integrations- und Migrationsforschung (BIM), Humboldt-Universität Berlin. http://www.bim.hu-berlin.de/media/201505-16_EFA-Forschungsbericht_Endfassung.pdf

Keddie, Nicki R., and Rudolph P. Matthee, eds. 2002. Iran and the Surrounding World: Interactions in Culture and Cultural Politics. Seattle/London: University of Washington Press.

Kelly, Philip, and Tom Lusis. 2006. Migration and the Transnational Habitus: Evidence from Canada and the Philippines. Environment and Planning A 38 (5): 831-847.

Khatib-Shahidi, Rashid Armin. 2013. German Foreign Policy Towards Iran Before World War II: Political Relations, Economic Influence and the National Bank of Persia, International Library of Middle East Studies. London/New York: I. B. Tauris.

Khosravi, Shahram. 2017. Precarious Lives: Waiting and Hope in Iran, Contemporary Ethnography. Philadelphia: University of Pennsylvania Press.

- 2018. A Fragmented Diaspora: Iranians in Sweden. Nordic Journal of Migration Research 8 (2): 73-81. https://doi.org/10.1515/njmr-2018-0013.

Kochwasser, Friedrich H. 1961. Iran Und Wir: Geschichte Der Deutsch-Iranischen Handels-Und Wirtschaftsbeziehungen, Schriftenreihe Reihe: DeutschAusländische Beziehungen. Herrenalb/Schwarzwald: Horst Erdmann.

Kohl, Helmut. 1991. Regierungserklärung Zur 12. Wahlperiode des Deutschen Bundestages: Auszug betreffend Europa und die europäische Integration. http://helmut-kohl.kas.de/index.php?menu_sel=17\&menu_sel $2=$ \&menu_sel3=8menu_sel $4=8 \mathrm{msg}=609$ 
Koser Akcapar, Sebnem. 2006. Conversion as a Migration Strategy in a Transit Country: Iranian Shiites Becoming Christians in Turkey. International Migration Review 40 (4): 817-853. https://doi.org/10.1111/j.1747-7379. 2006.00045.x.

Kunz, Egon F. 1973. The Refugee in Flight: Kinetic Models and Forms of Displacement. International Migration Review 7 (2): 125-146. https://doi. org/10.2307/3002424.

Lahire, Bernand. 1999. Champ, hors-champ, contrechamp. In Le travail sociologique de Pierre Bourdieu: dettes et critiques, ed. Bernand Lahire, 23-58. Paris: La Découverte.

Lamont, Michèle. 2012. Toward a Comparative Sociology of Valuation and Evaluation. Annual Review of Sociology 38 (1): 201-221. https://doi. org/10.1146/annurev-soc-070308-120022.

Lamont, Michèle, and Virág Molnár. 2002. The Study of Boundaries in the Social Sciences. Annual Review of Sociology 28 (1): 167-195. https://doi. org/10.1146/annurev.soc.28.110601.141107.

Lamont, Michèle, Graziella Moraes Silva, Jessica S. Welburn, Joshua Guetzkow, Nissim Mizrachi, Hanna Herzog, and Elisa Reis. 2016. Getting Respect: Responding to Stigma and Discrimination in the United States, Brazil, and Israel. Princeton/Oxford: Princeton University Press.

Levitt, Peggy, and Nina Glick Schiller. 2004. Conceptualizing Simultaneity: A Transnational Social Field Perspective on Society. International Migration Review 38 (3): 1002-1039. https://doi.org/10.1111/j.1747-7379.2004. tb00227.x.

Maghbouleh, Neda. 2017. The Limits of Whiteness: Iranian-Americans and the Everyday Politics of Race. Stanford: Stanford University Press.

Malek, Amy. 2015. Producing Culture, Producing Practice: Iranians in Sweden and Canada. PhD Dissertation, UCLA, Los Angeles.

2019. Subjunctive Nostalgia of Postmemorial Art: Remediated Family Archives in the Iranian Diaspora. Memory Studies: 1750698019843977. https://doi.org/10.1177/1750698019843977.

Marcus, George. 1995. Ethnography in/of the World System: The Emergence of Multi-Sited Ethnography. Annual Review of Anthropology 24: 95-117.

Marschke, Britta, and Heinz Ulrich Brinkmann, eds. 2015. "Ich habe nichts gegen Ausländer, aber... ": Alltagsrassismus in Deutschland. Berlin: LIT Verlag.

Martuccelli, Danilo. 2006. Penser l'intermonde, ou comment oublier le problème de l'ordre social. Revue Du MAUSS 1 (27): 431-443.

— 2009. Qu'est-ce qu'une sociologie de l'individu moderne? Pour quoi, pour qui, comment? Sociologies et Société 41 (1): 15-33. 
McAuliffe, Cameron. 2007. A Home Far Away? Religious Identity and Transnational Relations in the Iranian Diaspora. Global Networks 7 (3): 307-327. https://doi.org/10.1111/j.1471-0374.2007.00171.x.

- 2008. Transnationalism Within: Internal Diversity in the Iranian Diaspora. Australian Geographer 39 (1): 63-80. https://doi. org/10.1080/00049180701877436.

Messina, Anthony M. 2007. The Logics and Politics of Post-WWII Migration to Western Europe. Cambridge: Cambridge University Press.

Migration Policy Institute. 2018. Asylum Applications in the EU/EFTA by Country, 2008-2017. Migration Policy Institute. https://www.migrationpolicy.org/programs/data-hub/charts/asylum-applications-eueftacountry-2008-2017

Mobasher, Mohsen. 2006. Cultural Trauma and Ethnic Identity Formation Among Iranian Immigrants in the United States. American Behavioral Scientist 50 (1): 100-117. https://doi.org/10.1177/0002764206289656.

Moghaddari, Sonja. 2015. Migrations et Modernités Iraniennes: Les Familles Transnationales. Paris: Editions du cygne.

Mushaben, Joyce Marie. 2017. Wir Schaffen Das! Angela Merkel and the European Refugee Crisis. German Politics 26 (4): 516-533. https://doi.org/1 0.1080/09644008.2017.1366988.

Nadjmabadi, Shahnaz, ed. 2009. Conceptualizing Iranian Anthropology: Past and Present Perspectives. New York: Berghahn Books.

Narayan, Kirin. 1993. How Native Is a 'Native' Anthropologist? American Anthropologist, New Series 95 (3): 671-686. https://doi.org/10.2307/679656.

Nassehi-Behnam, Vida. 1991. Iranian Immigrants in France. In Iranian Refugees and Exiles since Khomeini, ed. Ashgar Fathi, 102-116. Costa Mesa: Mazda Publishers.

Nieswand, Boris. 2017. Towards a Theorisation of Diversity. Configurations of Person-Related Differences in the Context of Youth Welfare Practices. Journal of Ethnic and Migration Studies 43 (10): 1714-1730. https://doi.org/10.108 0/1369183X.2017.1293593.

Nohl, Arnd-Michael, Karin Schittenhelm, Oliver Schmidtke, and Anja Weiss. 2014. Work in Transition: Cultural Capital and Highly Skilled Migrants' Passages into the Labour Market. Toronto/Buffalo/London: University of Toronto Press.

Nowicka, Magdalena. 2013. Positioning Strategies of Polish Entrepreneurs in Germany: Transnationalizing Bourdieu's Notion of Capital. International Sociology 28 (1): 29-47. https://doi.org/10.1177/0268580912468919. 
2014. Migrating Skills, Skilled Migrants and Migration Skills: The Influence of Contexts on the Validation of Migrants' Skills. Migration Letters: Mobile Inequalities in a Mobile Europe 11 (2): 171-186.

OECD-UNDESA. 2013. World Migration in Figures. https://oecd.org/els/ mig/World-Migration-in-Figures.pdf

Office for National Statistics. 2015. Population by Country of Birth and Nationality Report: August 2015. http://www.ons.gov.uk/peoplepopulationandcommunity/populationandmigration/internationalmigration/articles/ populationbycountryofbirthandnationalityreport/2015-09-27

Ong, Aihwa. 1992. Limits to Cultural Accumulation: Chinese Capitalists on the American Pacific Rim. Annals of the New York Academy of Sciences 645 (1): 125-143. https://doi.org/10.1111/j.1749-6632.1992.tb33489.x.

. 1996. Cultural Citizenship as Subject-Making: Immigrants Negotiate Racial and Cultural Boundaries in the United States [and Comments and Reply]. Current Anthropology 37 (5): 737-762. https://doi.org/10.2307/2744412.

. 1999. Flexible Citizenship: The Cultural Logics of Transnationality. Durham: Duke University Press.

Portes, Alejandro. 1999. Conclusion: Towards a New World - The Origins and Effects of Transnational Activities. Ethnic and Racial Studies 22 (2): 463-477. https://doi.org/10.1080/014198799329567.

Portes, Alejandro, Luis Eduardo Guarnizo, and Patricia Landolt. 1999. The Study of Transnationalism: Pitfalls and Promises of an Emergent Social Field. Ethnic and Racial Studies 22 (2): 217-237.

Pries, Ludger. 1996. Transnationale soziale Räume. Theoretisch-empirische Skizze am Beispiel der Arbeitswanderungen Mexiko-USA. Zeitschrift für Soziologie 25: 437-453.

Public Affairs Alliance of Iranian Americans. 2014. Iranian Americans: Immigration and Assimilation. https://paaia.org/wp-content/uploads/2017/04/iranianamericans-immigration-and-assimilation.pdf

Pyke, Karen, and Tran Dang. 2003. 'FOB' and 'Whitewashed': Identity and Internalized Racism Among Second Generation Asian Americans. Qualitative Sociology 26 (2): 147-172. https://doi.org/10.1023/A:1022957011866.

Robbins, Joel, and Julian Sommerschuh. 2016. Values. In The Cambridge Encyclopedia of Anthropology, ed. Felix Stein, Sian Lazar, Matei Candea, Hildegard Diemberger, Joel Robbins, Sanchez, and Rupert Stasch. https:// doi.org/10.29164/16values.

Sadeghi, Sahar. 2015. Boundaries of Belonging: Iranian Immigrants and Their Adult Children in the US and Germany. In Identity and Exile: The Iranian 
Diaspora Between Solidarity and Difference, ed. Heinrich-Böll-Stiftung and Transparency for Iran, 117-131. Berlin: Heinrich-Böll-Stiftung and Transparency for Iran.

2018a. Host Discrimination, Bounded Mobility, and Bounded Belonging: Iranians in Germany. In The Iranian Diaspora: Challenges, Negotiations, and Transformations, ed. Mohsen Mobasher Mostafavi, 50-73. Austin: University of Texas Press.

. 2018b. Racial Boundaries, Stigma, and the Re-Emergence of 'Always Being Foreigners': Iranians and the Refugee Crisis in Germany. Ethnic and Racial Studies 42: 1-19. https://doi.org/10.1080/01419870.2018.1506145. Said, Edward W. 1978. Orientalism. New York: Vintage Books.

Sanadjian, Manuchehr. 1995. Temporality of 'Home' and Spatiality of Market in Exile: Iranians in Germany. New German Critique, Germany: East, West, and Other 64: 3-36.

Sarrazin, Thilo. 2010. Deutschland schafft sich ab: Wie wir unser Land aufs Spiel setzen. München: Deutsche Verlags-Anstalt.

Shooman, Yasemin. 2014. “... Weil ihre Kultur so ist”: Narrative des antimuslimischen Rassismus, Kultur und soziale Praxis. Bielefeld: transcript Verlag.

Smith, Michael Peter. 2005. Power in Place/Places of Power: Contextualizing Transnational Research. City \& Society 17 (1): 5-34. https://doi.org/10.1525/ city.2005.17.1.5.

Sökefeld, Martin. 2004. Das Paradigma kultureller Differenz: Zur Forschung und Diskussion über Migranten aus der Türkei in Deutschland. In Jenseits des Paradigmas kultureller Differenz: Neue Perspektiven auf Einwanderer aus der Türkei, ed. Martin Sökefeld, 9-33. Bielefeld: transcript Verlag.

Sreberny-Mohammadi, Leili. 2013. Coffee Shops and Cigarettes: On the 'Return' to Tehran of Young Diasporic Iranians. Iranian Studies 46 (1): 115-130. https://doi.org/10.1080/00210862.2012.740900.

Statistisches Amt für Hamburg und Schleswig-Holstein. 2018. Bevölkerung mit Migrationshintergrund in den Hamburger Stadtteilen Ende 2017: Mehr als ein Drittel aller Hamburgerinnen und Hamburger hat einen Migrationshintergrund. https://www.statistik-nord.de/fileadmin/Dokumente/ Statistik_informiert_SPEZIAL/SI_SPEZIAL_III_2018.pdf

Statistisches Bundesamt. 2017a. Bevölkerung in Privathaushalten nach Migrationshintergrund im engeren Sinne nach ausgewählten Herkunftsländern. Destatis: Statistisches Bundesamt. https://www.destatis. de/DE/ZahlenFakten/GesellschaftStaat/Bevoelkerung/ MigrationIntegration/Migrationshintergrund/Tabellen/ MigrationshintergrundStaatsangehoerigkeitStaaten.html 
- 2017b. Bevölkerung und Erwerbstätigkeit: Bevölkerung mit Migrationshintergrund Ergebnisse des Mikrozensus 2015. Destatis. https:// www.destatis.de/DE/Publikationen/Thematisch/Bevoelkerung/ MigrationIntegration/Migrationshintergrund2010220157004. pdf?_blob=publicationFile

Stoler, Ann Laura. 2009. Along the Archival Grain: Epistemic Anxieties and Colonial Common Sense. Princeton/Woodstock: Princeton University Press.

Su, Phi Hong. 2017. 'There's No Solidarity': Nationalism and Belonging Among Vietnamese Refugees and Immigrants in Berlin. Journal of Vietnamese Studies 12 (1): 73-100. https://doi.org/10.1525/jvs.2017.12.1.73.

Subrahmanyam, Sanjay. 1992. Iranians Abroad: Intra-Asian Elite Migration and Early Modern State Formation. The Journal of Asian Studies 51 (2): 340-363. https://doi.org/10.2307/2058032.

Terkessidis, Mark. 2004. Die Banalität des Rassismus: Migranten zweiter Generation entwickeln eine neue Perspektive, Kultur Und Soziale Praxis. Bielefeld: transcript Verlag.

The World Bank. 2018. Overview. http://www.worldbank.org/en/country/ iran/overview

Therme, Clément. 2013. De La Nature Du Régime Iranien. Relations Internationales 2 (154): 143-159.

UNICEF. 2013. Migration Profiles Iran (Islamic Republic of). http://esa.un. org/miggmgprofiles/indicators/files/Iran.pdf

Vahabi, Nader. 2012. ATLAS de La Diaspora Iranienne. Paris: Karthala.

Vaught, Sabina, and Gabrielle Orum Hernández. 2017. Along Ghostly Grains: Toward an Ethnography of Policy. In The Anthropology of Education Policy: Ethnographic Inquiries into Policy as Sociocultural Process, ed. Angelina Castagno and Teresa McCarty, 158-180. New York/Abingdon: Routledge.

Vertovec, Steven. 2007. Super-Diversity and Its Implications. Ethnic and Racial Studies 30 (6): 1024-1054. https://doi.org/10.1080/01419870701599465.

—. 2015. Introduction: Formulating Diversity Studies. In Routledge International Handbook of Diversity Studies, ed. Steven Vertovec, 1-20. London: Routledge.

- 2018. The Public Understanding of Migration. Max Planck Gesellschaft. https://www.mpg.de/ 12570028 / the-public-understandingof-migration?c=2249

Vivier-Muresan, Anne-Sophie. 2006. Le code de politesse iranien (tâarof) ou la fiction du lien social. L'Homme 180: 115-138. 
Vollmer, Bastian, and Serhat Karakayali. 2018. The Volatility of the Discourse on Refugees in Germany. Journal of Immigrant \& Refugee Studies 16 (1-2): 118-139. https://doi.org/10.1080/15562948.2017.1288284.

Wacquant, Loïc. 1992. The Structure and Logic of Bourdieu's Sociology. In An Invitation to Reflexive Sociology, ed. Pierre Bourdieu and Loïc Wacquant, 1-47. Cambridge/Oxford: Polity Press.

2018. Four Transversal Principles for Putting Bourdieu to Work. Anthropological Theory 18 (1): 3-17. https://doi.org/10.1177/146349961 7746254.

Weiss, Anja. 2001. Rassismus als symbolisch vermittelte Dimension sozialer Ungerechtigkeit. In Klasse und Klassifikation. Die symbolische Dimension sozialer Ungerechtigkeit, ed. Anja Weiss, Cornelia Koppetsch, Albert Scharenberg, and Oliver Schmidtke, 79-108. Opladen: Westdeutscher Verlag.

- 2005. The Transnationalization of Social Inequality: Conceptualizing Social Positions on a World Scale. Current Sociology 53 (4): 707-728.

Werbner, Pnina. 1990. The Migration Process: Capital, Gifts and Offerings Among British Pakistanis. New York/Oxford/Munich: Berg Publishers.

Wimmer, Andreas, and Nina Glick Schiller. 2002. Methodological Nationalism and Beyond: Nation-State Building, Migration and the Social Sciences. Global Networks 2 (4): 301-334. https://doi.org/10.1111/1471-0374.00043.

Wolf, Eric. 1982. Europe and the People Without History. Berkeley/Los Angeles/ London: University of California Press.

Žižek, Slovoj. 2004. What Rumsfeld Doesn't Know That He Knows About Abu Ghraib. Lacan.Com. http://www.lacan.com/zizekrumsfeld.htm 
Open Access This chapter is licensed under the terms of the Creative Commons Attribution 4.0 International License (http://creativecommons.org/licenses/ by/4.0/), which permits use, sharing, adaptation, distribution and reproduction in any medium or format, as long as you give appropriate credit to the original author(s) and the source, provide a link to the Creative Commons licence and indicate if changes were made.

The images or other third party material in this chapter are included in the chapter's Creative Commons licence, unless indicated otherwise in a credit line to the material. If material is not included in the chapter's Creative Commons licence and your intended use is not permitted by statutory regulation or exceeds the permitted use, you will need to obtain permission directly from the copyright holder.

(c) (i) 


\section{2}

\section{Cohesion and Conflict in Transnational Merchant Families}

[Ali] is a merchant, an importer, whose company is located in Tehran, and in Tabriz, and at the Ballinndamm in Hamburg. He plays an important role in Hamburg's big Persian colony. Since decades, the Persians are wellreputed merchants in our Hanseatic city. Those who settled in Hamburg and their families brought to us a little bit of Orient. In their well-kept homes near the Alster, they cultivate native custom and manner, even if their children grew on the shores of Elbe and Alster and they only went to school with Jungs and Deerns [local dialect: boys and girls] from Hamburg. (Hamburger Anzeiger, 17/08/1953, ${ }^{1}$ author's translation, emphasis in the original)

This extract of a newspaper article from 1953 portrays, in the example of Ali, the situation of Iranian merchants in Hamburg from a local German viewpoint. The quotation underlines the transnational dimension of Ali's business activities. It presents the local insertion of merchants as deriving from their important place in the local economy over several decades.

\footnotetext{
${ }^{1}$ All citations from the Hamburg city archives (Staatsarchiv Hamburg, STAHH) are in footnotes: Hamburger Anzeiger, "In zwölf Monaten: Moschee in Hamburg", 17/08/1953, no. 177, Staatliche Pressestelle I-IV (1919-1954), 135-1 I-IV_4636, STAHH.
} 
Thereby, the article states that Iranian merchant families maintain Iranian values in private, but conform to local ways of life in public. Further, it alludes to the role of family relations in their local engagements, and implicitly poses the question of the possibilities for a greater integration of their German-grown children. This chapter concentrates on diversity within kin groups. Utilizing a diachronic approach, I investigate how Ali and Jalal, two merchants with Azeri and Gilaki ethnic identifications who came to Hamburg in the 1930s, mobilized kinship relations to generate capital. Which role do constructions of gender, generational, and age hierarchies play in differentiation within these transnational families? How do these dynamics influence the descendants' own identifications and their usage in strategies of capital creation, in particular, the way they position themselves in Iranian social fields? At the same time, this ethnographic analysis that interweaves different sources of material, oral history accounts of living family members and contemporaries, secondary literature, and family and public archives also aims at historicizing Iranian immigration to Hamburg.

In anthropology, family relations are conceived of not as naturally given, but as socially constructed. Kinship is a state of doing rather than a state of being (Schneider 1984). Defined through its relationality, it relies on a "mutuality of being", that is, on collective experience of emotions and life events (Sahlins 2013). Following Pierre Bourdieu (1990, 167), kinship is also a set of possible relations one may draw upon for their strategic and practical use through the engagement in "constant maintenance work" in the form of "material and symbolic exchanges". I thus understand kinship through the description of the struggle about the definition of roles within a system of relationships, moving between changing degrees of differentiation and connection (Strathern 2014).

For at least 20 years now, scholars have been interested in understanding the role of the family in transnational migration. In coherence with the conception of kinship as a matter of practice, transnational families are defined

as families that live some or most of the time separated from each other, yet hold together and create something that can be seen as a feeling of collec- 
tive welfare and unity, namely 'familyhood', even across national borders. (Bryceson and Vuorela 2002, 3)

Studies of transnational families show that kinship relations may generate crucial resources: the creation and circulation of economic capital is certainly one of the most studied aspects of transnational kinship relations (Conway and Cohen 1998; Monsutti 2005; Sana and Massey 2005). Moreover, these ties represent a social resource which migrants may build on, for example, when emigrating (Massey et al. 1998, 42ff.; Moghaddari 2015, 134f.), or rely on for child care when being away (Baldassar and Merla 2014). In her study of Chinese transnational business families, Aihwa Ong (1999) made an important contribution to the study of the way kinship, that is, relations of alliance and filiation, is involved in practices of flexible capital creation through migration. Ong demonstrates how family fathers strategically place their kin in different countries to engage in professional trajectories, higher education, citizenship acquisition, and marriage alliances, in order to increase the family's collective efficiency in generating capital in different social fields (1999, 124-57). This chapter expands on her work as it interrogates, through the relational approach to kinship, the family members' responses to hierarchical role attribution. Moreover, based on a historically informed ethnography and research on kinship relations in other transnational trade networks (Curtin 1984; Fewkes 2009), it stresses the dimension of time and temporality in the understanding of geographical flexibility.

A brief sketch of the socio-economic organization of merchants in Iran and in Germany sets the grounds for the ethnographic description of Iranian merchants' flexible strategies of capital creation through marriages, transnational brotherly relations, and the image of the nuclear family. Building on these descriptions, the analysis of differentiations and disruptions that developed between kin offers an understanding of how the experience of kinship, in combination with inherited resources (or their lack), influences the ways in which migrants' descendants engage with other people of Iranian origin. 


\section{Bazaris Meet Kaufmänner: Conditions of Early Iranian Mercantile Migration}

As mentioned in the introduction, Iranian migration to Hamburg began - although initially very slowly_after the conclusion of the first "commercial and friendship treaty" between Iran and the Hanseatic cities of Bremen, Lübeck, and Hamburg ${ }^{2}$ in 1857 (Khan, Rumpf 23/07/1857 3 ). Of course, commercial cooperation between Europe and Iran was not completely new: economic relations can be traced back to historical trade networks of the silk route which connected Europe to Asia, passing through Iran (Tsutomu 2013, 235). ${ }^{4}$ Local products, such as carpets, dried fruits, silk worms, cocoons, and opium were exported to Russia, to the Caucasus, and, via Turkey, to Europe. According to the 80-year-old merchant Akbar, Istanbul was one of the first foreign destinations of successful Iranian merchants. ${ }^{5}$ However, with the rising efficiency of $\operatorname{trade}^{6}$ and with growing competition (Tsutomu 2013, 247), they searched for alternative business strategies. The establishment of bilateral trade relations with German cities thus offered the possibility to set up a branch in Hamburg and reach new markets in Europe and North America.

As in many similar historical cases, these trade networks were mainly based on kinship relations. Fewkes (2009, 61ff.) and Van (2011), for example, describe the centrality of filiation and alliance in sustaining reliability and creating resources acknowledged in different locations of trade

\footnotetext{
${ }^{2}$ At that time, Germany was not a state yet. Until the foundation of the German Reich under William I in 1871, the city of Hamburg was part of the German Confederation, a loose association of 39 German states.

${ }^{3}$ Ferrokh Khan, Vincent Rumpff, Beglaubigte Copie des Freundschafts- und Handelsvertrags der Hansestädte mit Persien d.d. Paris, 23/07/1857, Ältere Register E III, 132-5/2, STAHH. See also Gropp and Shaghaghi (2009).

${ }^{4}$ One of its main routes passed through the northern provinces of Iran (Azerbaijan, Gilan, and Mazanderan), which, thanks to their thriving commerce, were the most prosperous regions of Iran in the nineteenth century.

${ }^{5}$ The Persian Gulf region is another historical center for Persian merchant houses (Moghadam 2013), but in Hamburg, merchants from north Iran were much more significant.

${ }^{6}$ Over the course of the nineteenth century, the old system of caravans passing the silk routes was gradually replaced by railway and steam boats (Tsutomu 2013, 238f.).
} 
within historical trade networks in Ladakh and New England, respectively. Indeed, setting up a new branch in Hamburg was frequently a son's task. Importantly, this migration was predominantly male, as most of these rather young men were either bachelors or they left their wives and children in Iran. This group of pioneering merchants was marked by strong ethnic, linguistic, and religious diversity, ${ }^{7}$ but held together by a shared adherence to the logics of Iranians bazari networks.

The Iranian marketplace, the bazar, is a physical space within which social and economic transactions take place in hierarchized networks (Keshavarzian 2007, 16). The term bazari, that can be attributed to the pioneering merchants, refers to

exporters, wholesalers, retailers, brokers, and middlemen who make up the historic commercial class situated in urban centers and involved in diffuse, complex, and long-term exchange relations with the city, the nation, and international markets. (Keshavarzian 2007, 228)

In Iran, the bazaris, just like urban entrepreneurs and the clergy, can be defined as the traditional "propertied middle class" (Abrahamian 1982, 432f.). At the time the first merchants came to Hamburg, the Iranian bazar's social structure was characterized by a high level of social, cultural, ethnic, and religious diversity. According to Arang Keshvarzian, there was no official monitoring organism that supervised commercial activities. Instead, based on a tight social network of mutual acquaintance, informal socio-economic activities ${ }^{8}$ relied on a system of reputation in which traders could monitor each other's activities, reward honesty, and sanction betrayal through public shaming. Multiplex relations, including kinship, friendship, neighborhood relations, and common religious and leisure practices, cutting across professional hierarchies sustain the mutual monitoring. Shared values such as honesty, generosity, religious adherence, modesty, and expertise were the basis for collective identifications. Conflicts were resolved internally to preserve the reputation of the com-

\footnotetext{
${ }^{7}$ As Sepehr explained to me, it was constituted by Christians of ethnic Armenian origin, Jews, and Muslims identifying as Azari or Persian origin.

${ }^{8}$ Most long-term commercial collaboration was concluded with a handshake, without a legal contract.
} 
munity as a whole. Long-term cooperation, secured by the ongoing creation of mutual debt in exchange, was a necessary condition to this reputation system (Keshavarzian 2007, 17, 88ff.).

The Iranian bazari offspring that arrived in Hamburg met a relatively favorable professional environment. The city already looked back on a history of several hundred years as an important northern European trading port. From the thirteenth century onward, Hamburg's merchants were involved in a vast trade network, the Hanse. It connected important port cities in the area of the North and Baltic Sea to Western European and Mediterranean trade networks (Wubs-Mrozewicz 2013, 6). Interestingly, the structure of trade in this network had much in common with the social organization of the historical Tehran bazar. Indeed, the Hanse was not so much a formal trading trust than a shared concept. As in the bazar, commercial cooperation was based on a system of reputation. Similarly, this involved mutual monitoring through multiplex long-term relations with shared values tying merchants together (Ewert and Selzer 2009, $5 \mathrm{ff}$.). Here, too, kinship, marriage, and fictive kinship were the social glue holding together long-term cooperation (Ewert and Sunder 2011, 6). In Hamburg, the mercantile spirit survived after the decline of the Hanse in the seventeenth century (Wubs-Mrozewicz 2013, 14f.) and its incorporation into the German Reich in 1871, thanks to the ongoing economic activity and strong political influence of a restricted number of highly interrelated mercantile and legal bourgeois families. Thus, they successfully asserted their position against the aristocracy, the military, and intellectual elite until the early twentieth century and were attributed important political positions after the fall of the German monarchy in 1918 (Evans 1991, 120-35).

In sum, shared professional ethics facilitated the insertion of Iranian merchants in the local economy. In the social organization of local and Iranian merchants, kinship relations were central. However, as we will see, the relations of Iranians with Hamburg's well-established merchant houses rarely went beyond professional activities, at least for the first generation. 


\section{Pioneers in Flexible Capital Creation}

After World War I and Shah Reza Pahlavi's coronation in 1925, Iran and Germany, under the Weimar Republic, increased their bilateral relations out of mutual interest: the Shah's cooperation with Germany, an industrialized country with only a minor colonial past, was part of his intention to undermine the British and Russian influence in Iran (Azimi 2008, 111f.). The Weimar Republic, in turn, was in search for an independent trade partner that exported raw material and provided a market for German manufactured goods. Although, from 1929, bilateral trade relations were endangered by a trade imbalance deriving from the Great Depression and political scandals (Mahrad 1979, 21-50; Digard et al. 2007, 75), it was in this context that the first Iranian merchants set up businesses in Hamburg. ${ }^{9}$

The emerging businessman Ali came to Hamburg in 1931 and I met his youngest son Siavash (through an employee at the Ohlsdorf cemetery) at his home in rural Lower Saxony in 2013. As the practicing Muslim in his early sixties was very interested in my research, arguing that there is a lack of documentation on the history of Iranian migration to Hamburg, he also arranged interviews with his oldest brother Sepehr and his sister Gita. It was Sepehr who told me that, in migrating, their father Ali joined a distant relative who was already an established merchant. He arrived together with his friend Khalil, the son of a successful merchant from Tabriz-a sort of tie that represented an important social capital in the new city. Ali was born in Tabriz, the capital of the northwestern Iranian province of Eastern Azerbaijan, as the third of four sons of his father's first wife (see Fig. 2.1). His father was no bazari, but the administrator of a large estate. According to Siavash, Ali was from a highly religious family, and he enjoyed education at foreign schools, which provided him with useful language skills in French and English. Consequently, Siavash commented, "My father was the one among the brothers whose education

\footnotetext{
${ }^{9}$ Trade networks did not only span between Iran and Germany, but some merchant houses, as Keyanian Company (Keyaniyan 2014) founded in 1931 or Ghazanfar \& Azad, founded in 1938 (Handelsregister, 231-7_B1986-56 Band I, STAHH, see copy in the appendix), were partnerships with Iranian traders from an older hub for Iranian trade, Bombay.
} 


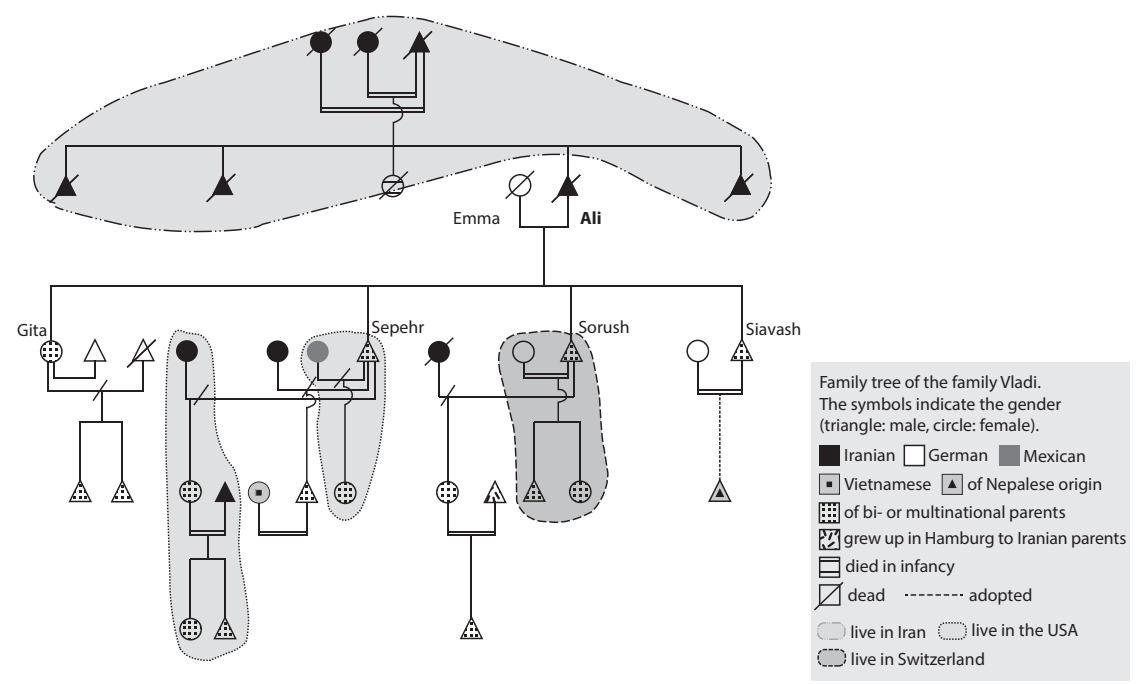

Fig. 2.1 Ali's family tree, all non-specified people live or lived in Germany

people thought would be worth to invest in - more than the others" (Interview, July 2013).

Ali was a teenager when his father died, but, according to his children, it fell to him to ensure the financial survival of the family. Their observation hints to the fact that, not least through his education, Ali defied the typical hierarchy of sibling groups structured by order of birth (and gender, if applicable) (Kuper 2004, 212). He entered the bazar economy with only a modest capital and when he was in his early thirties and unmarried, the self-made man started to work for an Iranian merchant in Hamburg, traveling back and forth to maintain contacts with trade partners. Iranian trade houses came along with their own social and professional hierarchy, with import-exporters at their head, followed by managers (Geschäftsführer, Prokurist), scripts, and other clerks (Keshavarzian 2007, 78ff.). I learned from archival material (Lisowski $03 / 11 / 1947^{10}$ ) and from my interlocutors that it was usual practice for newcoming Iranians like Ali to first work for one of the established

\footnotetext{
${ }^{10}$ Lisowski (Stadtsekretär), handwritten comment, 03/11/1947, doc.3, indemnification request of Mahmout Chenavar, 351-11_54744, STAHH.
} 


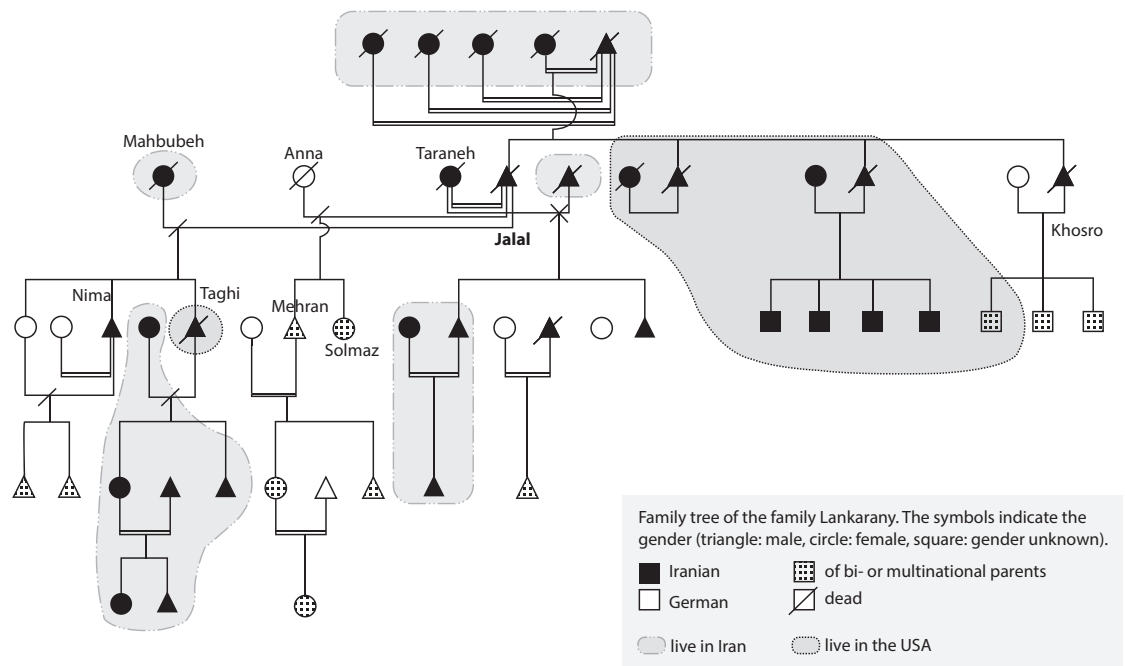

Fig. 2.2 Jalal's family tree, all non-specified people live or lived in Germany. The data for the extended family is simplified for reasons of pertinence

bazaris, and, once they had gained sufficient social, cultural, and economic capital, open their own merchant house. Indeed, in 1933-four months after Adolf Hitler became the chancellor of Germany-Ali finally set up his own business. His Iranian nationality thereby did not pose a problem, as Iranians were considered Aryans according to the Nazis' racial ideology (Abrahamian 2008, 86). "Luckily they did not know that, as an Azeri, he was an ethnic Turk", Siavash commented with a wink.

Jalal came to Hamburg three years after Ali, in 1936, when he was 32 years old, and I met his daughter Solmaz, an energetic woman in her late fifties at the Color festival in June 2013 (see Chap. 5). She told me that, contrary to Ali, Jalal was not a self-made-man: he was the son of a bazari from Rasht, the capital of Gilan province, who traded rice and dried fruits to Baku, Azerbaijan. His wealthy father had 4 wives and 12 children (see Fig. 2.2). Nevertheless, as his first son, Jalal had been much coddled. When his father's enterprise ran into financial difficulties in 1936, he was sent to Hamburg to diversify capital assets. According to a biographer of the family, he left his wife Mahbubeh, pregnant with his second son Taghi, as well as his three-year-old son Nima behind in Iran 
(Lankarany 2009, 11). Jalal's father's reputation constituted social capital that helped him earn the trust of the local Iranian merchants and get employed as a typist.

Thus, Ali and Jalal both came to Hamburg in the context of dynamics Aihwa Ong calls "flexible citizenship", that is, "the strategies and effects of mobile managers, technocrats, and professionals seeking to both circumvent and benefit from different nation-state regimes by selecting different sites for investments, work, and family relocation" (idem 1999, 112). Accordingly, to pursue their career in Hamburg and create economic capital, they built on social capital, in particular on family reputation, kinship, and friendship ties they had at their disposal in the transnational social fields of Iranian merchants.

\section{German Alliances?}

Of course, Ali and Jalal did not only strive to create capital in transnational, but also in local social fields. In their professional life, they conducted business with German merchants, and in the private domain, many married German women. Which German women?

One day in 1931, Ali went to conclude a business agreement with a Jewish German merchant, where he met the 15-year-old apprentice Emma. The young German woman, who grew up in poverty with her divorced mother and older sister, was impressed by the foreign merchant, who, according to the family's biographer, was elegantly dressed in a violet silk suit (Vladi 2004, 96). Encouraged by Ali's new friend Mohammad, a son of a successful bazari family, Ali and Emma married six years later. Their wedding ceremony took place in one of the most prestigious restaurants in Hamburg, the "Uhlenhorster Fährhaus". The couple will have one daughter, Gita, born in 1938, and three sons, Sepehr, Sorush, and Siavash, born in 1940, 1945, and 1948. Gita's memories show that her parents were one among many mixed couples:

Gita "There was the consul who was in office at the outbreak of the war, Abol Pourvali, and his German wife Gabi."

Sonja "He had a German wife?" 
Gita "Yes, she was an employee at the consulate (Konsulatsangestellte) and then he married her [...]. In the Mittelweg [street in the upper middleclass neighborhood Harvestehude] lived the Daroga family. He was Persian, she was German and they had a daughter whose hair was blond [...]. That was in [19]46, [19]47. Then, there was a certain Mister Chaichi, who had married a German from Peine, near Hannover. They married in Hannover - in Peine, and we were invited. I think the woman was from a patissier family." (Interview, March 2014)

Indeed, marrying a local, even across ethnic and religious boundaries, ideally, marrying into a local merchant family, was a frequent practice in certain historical merchant networks, such as those of merchant families from Ladakh. Such unions do not only secure the acquisition of localityspecific resources for the next generation, but also create new social resources through the spouse's relatives (Fewkes 2009, 75ff.; see also Curtin 1984). However, marriage practices were sometimes restrained by local social and political prescriptions that aimed to ensure the temporary nature of trade colonies (Van 2011, 276ff.). It is striking that, in Hamburg, most German women who married early Iranian merchants were of rather modest background. This was the case of both Emma and Anna, the young German model Jalal married in the early 1950s. Following Bourdieu, affinal relationships "are the product of strategies oriented towards the satisfaction of material and symbolic interests and organized by reference to a particular type of economic and social conditions" (idem 1990, 167). To better situate Ali's and Jalal's marriage, let us consider the different parties' interests in these alliances.

First, well-established upper- and middle-class families in Hamburg tended to encourage endogamy, as their companies were usually passed on to male descendants or affines (Evans 1991, 122). Alliances within the social group reduced the costs caused by professional apprenticeship and the creation of trust (Ziegler 2000, 19ff.). Although arranged marriages were no longer the norm in the early twentieth century, the father's consent to a marriage was normally necessary. German commercial middleclass patriarchs were thus rather reluctant to let their daughters marry Iranian merchants: the latter had the necessary economic but not social and cultural resources (e.g. language skills, business codes, religious 


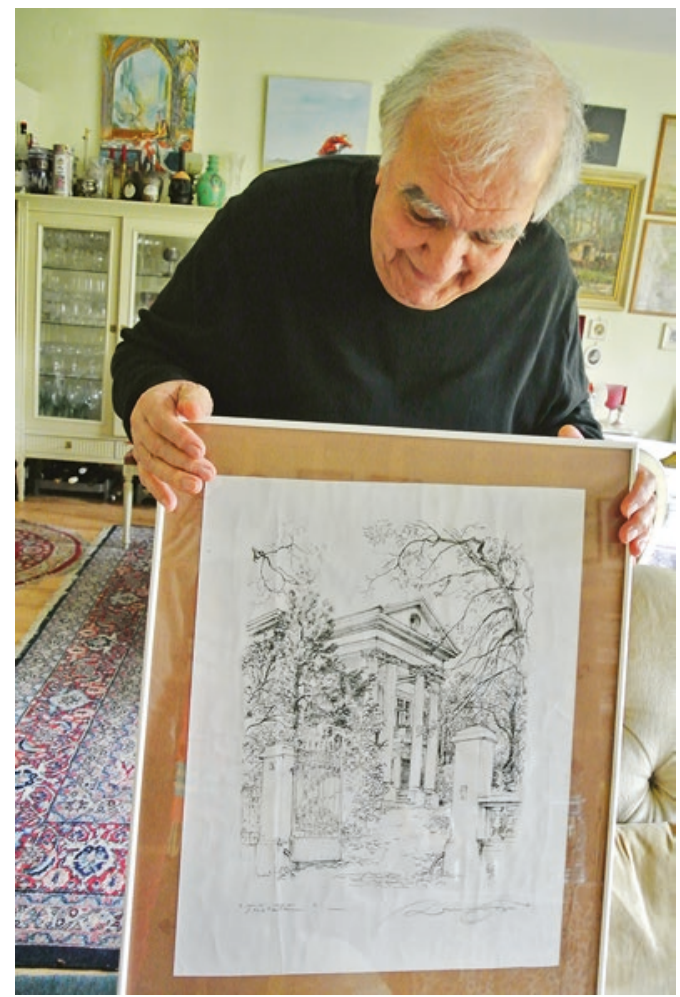

Image 2.1 Drawing of the villa Parviz inherited from his German parents-in-law. (April 2014, author's photo)

beliefs) relevant in social fields of Hamburg's German merchants_-and they were considered as racial Other, as we can see in Gita's highlighting the girl's blond hair as something remarkable. Significantly, Parviz told me that, when Louise married him in 1955, she did so against father's expressed opposition. Accordingly, the local industrial entrepreneur refrained from integrating his Iranian son-in-law into the family enterprise. However, the couple later lived in the family's villa, Louise's heritage, which Parviz shows me on the drawing below (Image 2.1).

Second, for German women of modest backgrounds, Iranian merchants were attractive marriage partners, in particular in times of crises (in the 1930s and after WWII), as, according to Parviz, these young men were-or pretended to be-affluent and rather generous. Significantly, 
Emma commented in her memoirs (cited in Vladi 2014, 12) that from the day she dated Ali "my life changed. I had a good, thoughtful boyfriend, we had a canoe ${ }^{11}$ and friends and I had a full stomach." Emma stopped working and experienced upward social mobility, evident in the couple's new lifestyle: they moved to Harvestehude (Evans 1991, 130) and bought a Mercedes Cabriolet. Simultaneously, with her marriage, Emma "became Iranian": she did not only get a new Iranian first name, the young woman had to exchange her German for the Iranian citizenship ${ }^{12}$ and convert to Islam, ${ }^{13}$ although, according to Siavash, she never practiced the religion. Emma's mother also benefitted from the marriage: Ali covered all her expenses and generously bought her a house on the countryside (Vladi $2004,98,2014,31)$. He thus created social and economic capital both within and through the family. In the photo (Image 2.2), the couple's claim for upward mobility is reflected in the elegance of Ali and Emma's dress and the centrality of their young family within the extended kin group.

Finally, expatriation offered young Iranian merchants a greater freedom for making the marriage of their choice. At that time, it was usual in Iran for marriages to be arranged according to family interests, in particular among merchants ${ }^{14}$ (Keshavarzian 2007, 95). An important factor in Ali's life was, according to his children, his wish to move back to Iran, which he maintained almost until his death. In the face of the restrictiveness of the local Iranian marriage market, Emma was a good choice for Ali. As she was not from a local merchant family, she was not likely to expect Ali to participate in their sociability. Moreover, although marrying into a German merchant family would have offered important opportunities for capital creation, a daughter of a well-established family may not have been open toward a return migration. Thus,

\footnotetext{
${ }^{11}$ Having a canoe meant being able to participate in middle-class leisure activities in a city with as many canals as Hamburg.

${ }^{12}$ Until the marriage law was changed in 1953 , German women lost their citizenship when marrying a foreigner (Einbock 2015).

${ }^{13}$ According to Shia Islamic matrimonial law, Muslim men can conclude a temporary marriage (siqeh) with a woman of Christian, Jewish, or Zoroastrian faith, but if the marriage is to be permanent, the woman has to convert to Islam (Nayyeri 2013).

${ }^{14}$ In diverse ways, marriages may still be arranged today in certain Iranian families (Moghaddari $2015,135-40)$.
} 


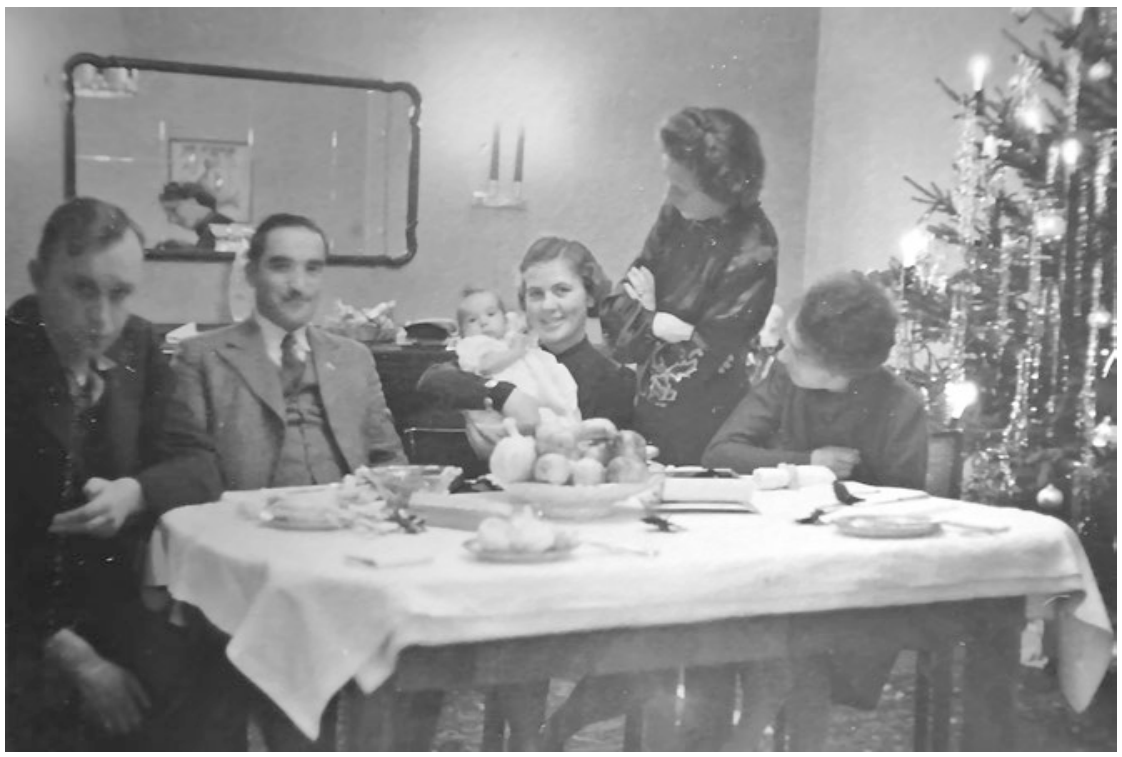

Image 2.2 Christmas 1938 and Emma's mother's place. From right to left: Emma's sister's husband, Ali, Emma's sister with Gita, Emma, and her mother (Siavash's family archives)

even though this marriage did not immediately provide him with economic resources, nor with German citizenship ${ }^{15}$ (cultural capital), becoming a head of family offered him the possibility to inhabit an image of a responsible adult, which increased his trustworthiness (social capital) among merchants.

Importantly, although Ali and Jalal both married Germans, they constructed their families around Iranian identifications for two reasons. First, there was a strong social cohesion among merchants of Iranian origin that relied on multiplex relations in which professional ties interweaved with kinship, friendship, and neighborly ties. Siavash told me that most Iranian merchant families settled in the same district, Harvestehude, which was also popular among local merchants. They had their office in the city's commercial center, and only their stock houses at

\footnotetext{
${ }^{15}$ It was not before a change in legislation in 1969 that such a union offered access to German citizenship for foreign men (Einbock 2015).
} 
the warehouse district. These links build largely on their identification as Iranian, and they represented their business' competitive advantage (see Chap. 3 for a detailed discussion).

Second, German society posed limitations to migrants inclusion (Aumüller 2009, 191). As mentioned earlier, German wives had to take Iranian citizenship. Consequently, their children had Iranian and no German passports. Reminiscent of the introductory quote to this chapter, when Ali and Jalal founded their families, a differentialist approach to immigration prevailed in Germany. Migrants' cultivation of difference was tolerated as it was seen as a guarantee for their return migration ${ }^{16}$ (Brubaker 2001, 537). Thus, Hamburg's society conceded pioneering Iranian merchants Iranian at the expense of German identifications.

The perception of these Iranian identifications was shaped by the German economic interest in trade with Iran, the people's fascination for the "exotic" coexisted with xenophobic and racist tendencies. Parviz, for instance, told me proudly that once, while he was walking on the street, German passersby asked him whether he was from Hollywood. Siavash, in contrast, reported "When I was at school, there were always two swear-words: carpet trader and camel driver [Kameltreiber]" (interview, July 2013).

Having described the first years of Ali's and Jalal's life in Hamburg, I need to make a short digression from the analysis of kinship relations in order to explain the type of relationship the two men entertained with one another.

\section{Why Ali and Jalal Were Not Friends}

According to Sepehr, about ten Iranian (and binational) families and a few bachelors lived in Hamburg before the World War II. Given the small number, Ali and Jalal must have known each other. However, there is no record of an encounter, and their children do not remember the other family. To understand Ali's and Jalal's relation, I suggest considering

\footnotetext{
${ }^{16}$ As shall be discussed in Chap. 4, it was only when the German society and politics began to accept the durability of immigration in the late 1990s, that this approach changed.
} 
their different ways to engage with political powers in their strategies of capital creation.

According to Siavash, Ali followed what he calls the "bazari mindset" (Bazarimentalität) in his political positioning: even if he did not agree with the political line of a government, thanks to skillful impression management (Goffman 1990), he pragmatically kept good relations with it in order not to endanger his business activities. He thus attended receptions at the Consulate General of Iran (established in 1934), and I could identify him on a picture at the celebration of Mohammad Reza Shah's wedding at the General Consulate in Hamburg in April 1939, published in a local newspaper (Hamburger Fremdenblatt, 26/04/1939, no 115, Staatliche Pressestelle I-IV (1919-1954), 135-1 I-IV_4636, STAHH). There, he was able to meet not only government officials, but also scientists and German trade professionals ${ }^{17}$ (Hamburger Anzeiger, 20/04/1934; Hamburger Fremdenblatt, 20/03/1936; Hamburger Fremdenblatt, 16/03/1940 ${ }^{18}$ ). If we are to believe Parviz, he even ordered a carpet based on a portrait of Adolf Hitler to be knotted in Tabriz and offered it to the Führer in person.

Contrary to the zealous newcomer and family man Ali, the grasswidower Jalal was a man-about-town. However, according to the merchant Omid, he was a political person. His daughter Solmaz confirmed:

Luckily, father was not religious, but moralistic. He was totally politically interested. He also watched the news all day and only read nonfiction books, and newspapers, as long as he could still read. (Interview, July 2013)

Jalal's political opinions had serious consequences on his opportunities to create capital. Although exchanges between Nazi Germany and Iran came to an abrupt end as the British and Russians occupied Iran in summer of 1941 (Mahrad 1979, 117-29, 181), he stayed in Hamburg during

\footnotetext{
${ }^{17}$ Preparing for a war, National-Socialist Germany intensified trade with Iran between 1936 and 1940 and became Iran's most important trading partner (Keddie 2006, 101).

${ }^{18}$ Hamburger Anzeiger, "Persisch-deutsche Handelsbeziehungen", 20/04/1934 no 92; Hamburger Fremdenblatt, "Iranisch-deutscher Abend", 20/03/1936, no 80; Hamburger Fremdenblatt, "Empfang des iranischen Generalkonsuls", 16/03/1940, no 75a, all Staatliche Pressestelle I-IV (1919-1954), 135-1 I-IV_4636, STAHH.
} 
WWII. In October 1944, during one of the parties he frequently organized at his apartment, he critiqued Adolf Hitler. On the following day, one of his German guests denounced him to the authorities. Soon, the Gestapo arrested Jalal. They proposed him to spy for the German government. Jalal refused, was sent to the concentration camp Bergen-Belsen, ${ }^{19}$ and was only liberated one year later by the British army, heavily struck by typhus. ${ }^{20}$ Anticipatory flexible capital creation-he had set up a bank account in the name of his sons in Geneva, Switzerland, to where his friend Nasser took his assets at his detention—saved him from losing his economic capital (Lankarany 2009, 25f.). However, as we will see, this episode will not remain the only time Jalal's proclivity to stick to his strong moral and political principles posed limitations to his capital creation.

For Ali's part, when the war started, he took his young family to Tabriz. After a year and a half, Emma pushed toward returning to Hamburg. When, in the summer of 1943, their home and the company premises were struck by bombs, the family moved to live with Emma's mother in the house Ali had bought for her on the countryside.

In the following decades, Ali continued to pragmatically maintain good ties with German and Iranian political power holders. Regularly, he and his family participated in receptions that took place in the local Iranian Consulate General and assisted, whenever possible, at events organized around Shah Mohammad Reza Pahlavi's visits in Hamburg in 1955 and 1967. According to Siavash, his father also entertained good ties with Hamburg's political and economic elite, and with highly positioned Iranian Shia clerics. These contacts were nourished not only through his thriving business but also through his leading role within the Iranian Shia Muslim community. In 1941, Ali co-established an Iranian Islamic burial ground ${ }^{21}$ in the city's main cemetery, and from the early

\footnotetext{
${ }^{19}$ The concentration camp Bergen-Belsen was situated in Lower Saxony, about $100 \mathrm{~km}$ South of Hamburg.

${ }^{20}$ According to archival sources, two other Hamburg-based Iranians were also arrested for political motivations and jailed in Concentration Camps (Hassan Lankarany, sworn declaration, 05/01/1948, doc. 8, Antrag auf Wiedergutmachung von Mahmout Chenavar, 351-11_54744/8, STAHH).

${ }^{21}$ According to Siavash, until then, corpses had been repatriated to Iran, which was no longer possible due to the war.
} 
1950 s, he became the head of an association of merchants that advocated for and co-financed the construction of the Imam Ali mosque, which is today Germany's second oldest still intact mosque (Verein der Förderer einer iranisch-islamischen Moschee in Hamburg e.V. 05/05/1955; Jess $\left.10 / 01 / 1958^{22}\right)$.

For his part, Jalal followed invitations on the occasion of the Shah's visits, as archival sources confirm (Hüber 11/02/1955; Hüber $15 / 02 / 1955^{23}$ ), but according to his daughter without Ali's fervor. Moreover, while Jalal showed himself very generous with his family and friends, he was not particularly interested in entertaining ties beyond this circle. From the mosque, he kept a critical distance as, according to Solmaz, he was an atheist.

Discrepancies between Ali's and Jalal's strategies of capital creation are thus apparent in the way they deal with political and religious power holders. They certainly reflect distinct personal values (for instance, political integrity versus economic security), which however interact with their unequal starting position: while Ali made private and professional alliances with the zeal of a self-made man with modest family resources, Jalal's privileged upbringing may have contributed to him being more reckless in social relations, in particular with the authorities. On the basis of their divergent values, they strove to create capital in different social fields_-and their interests did not coincide. Thus, foreshadowing an argument that I develop further in the following chapters, shifting boundaries among migrants not only depend on their trajectories in the country of immigration, but also on the compatibility of their engagement and respective positionality in local and transnational social fields.

\footnotetext{
${ }^{22}$ Verein der Förderer einer Iranisch-Islamischen Moschee in Hamburg e.V., extract from the minutes of the general assembly that took place on January 31, 1955, document no. 27, 05/05/1955; Jess (Senator), letter to the city mayor, 10/01/1958, Sonstige Glaubensbewegungen (1922-1988), Senatskanzlei II, 131-1 II_874, STAHH.

${ }^{23}$ Reinhard Hüber (president of the German-Iranian chamber of commerce), letter to Senator Ohlendorf, 11/02/1955, doc. 020.11-15; Reinhard Hüber, letter to Naso (secretary of the Nahund Mittelost Verein), 15/02/1955, both in "Inoffizieller Besuch von Mohammad Reza Schah und seiner Kaiserin Soraya”, Empfang und Essen im Festsaal des Rathauses, Empfänge und Besuche nach Einzelplan 0 (Verfassung und Verwaltung) (1947-1990.03), Senatskanzlei II, 137-1 II_4438, STAHH.
} 
To resume the discussion, Ali and Jalal's different values were also reflected in the way they practiced kinship. Let us first consider how they involved their siblings living in Iran in their transnational strategies of capital creation.

\section{Brotherly Ties Between Solidarity and Rivalry}

Ali and Jalal (re)built their transnational businesses in the years after the World War II, that had left Iran with a new Shah, Mohammad Reza Pahlavi, and a highly damaged economy (Mahrad 1979, 189ff.), and Hamburg, under British occupation, in destitution and shortage of essential goods (Sywottek 1986, 384). By the early 1950s, the newly founded Federal Republic's gross national product reached its pre-war strength, and economic growth remained unbroken until the mid-1970s - a phenomenon that became known as the "economic miracle" (Wirtschaftswunder) (Abelshauser 2004, 275). In 1951, Iran and Germany resumed their diplomatic relations, and the Federal Republic returned to being Iran's most important trading partner (Adli 1960, 290; Mousavian 2008, 15f.). The favorable economic conditions represented an important upswing in the German society. During these years, Jalal and Ali became successful entrepreneurs, managing five to ten employees, including German tax advisors and accountants — but sought different relations with their transnational family.

Around 1950, Jalal opened a factory for electrical accessories ${ }^{24}$ with the newest German technology in his hometown Rasht, in addition to the import-export business he ran in Hamburg. Thereby, he made his 17-year-old younger brother Khosro, who lived with him in Hamburg since 1946, an associate of the stock company. He also distributed further positions and shares among family members living in Iran. Jalal's involving of family members living in Iran corresponded to the primordial role of the family within the Iranian bazar economy discussed earlier. ${ }^{25}$ For

\footnotetext{
${ }^{24}$ At that time, it was a trend among wealthy bazaris in Iran to invest in industrial production (Keshavarzian 2007, 79).

${ }^{25}$ Similarly, the business records of the company Akbar Ghazafar indicate a large number of relatives, including his German wife, most of whom living in Tehran, among the shareholders
} 
him, it was a means to create trust from the important obligations deriving from exchanges in kinship relations (Sahlins 1972, 191ff.) and, at the same time, claim his role as the head of family after his father's death. While both brothers took over formal responsibilities in the transnational businesses, Jalal charged Khosro with business administration, while he himself had a more laid-back, representative role ${ }^{26}$ (Lankarany 2009, 144f.). As in many other places in the world, according to Christian Bromberger, in Iran the family is at the core of the social organization. Strong solidarity may develop between brothers, but it implies constant social control (Bromberger 2005, 136ff., see also idem 2013, 124ff.). Similarly, Pierre Bourdieu $(1990,170)$ states that "the closest genealogical relationship, that between brothers, is also the site of the greatest tension, and incessant work is required to maintain solidarity", that is, it is necessary to manage the tensions that may arise from conflicts of interest over the same resources. In Jalal's family, it were such conflicts, growing from contradictory strategies of capital creation, that put into question the brotherly solidarity_-but I am getting ahead of myself.

Ali, for his part, booked considerable economic success with his import-export company. According to Siavash, he mainly imported cotton, licorice, tragacanth, gum Arabic, dried fruits (khoshkbâr; mainly apricots, but also raisins, walnuts, pistachios), intestines, and, to a lesser extent, carpets. Exports were construction hardware, car locks, and bicycle parts (Vladi 2004, 99). Like Jalal, he also had an office in Tehran, but, as his sons explained, he did not involve local family members in his business. This was because, during the war, Ali's brothers had sold his heritage and invested it in commerce with Germany. When their gain was confiscated by the British after the occupation of Iran, it was lost forever (Vladi $2004,98)$. Indeed, social obligations and competition about resources may contribute to the fact that "the circle of solidarity is also that of the most common violence" (Monsutti 2004, 222). Research on Middle Eastern societies shows that it is not rare for relations among male patrilateral relatives, in particular among brothers, to be marked by rivalry

(Hamburger Abendblatt, 04/04/1963, doc. 26, Handelsregister, 231-7_B1986-56 Band II, $\mathrm{STAHH})$.

${ }^{26}$ Also, Solmaz told me that, when Khosro married a German, Jalal offered the couple a prestigious villa in an upper-class district — as a way to confirm his superior position. 
(Tapper 1979; Werbner 1990, 201; Monsutti 2004, 2011). In order to circumvent such competition, Ali tried to balance exchanges with his brothers, according to Siavash:

I remember my two brothers went to Iran once by car via Turkey, that was 1965, 1968. They carried a letter from my father to his brother, which featured - after many polite introductory phrases - apparently also a phrase whose essence was 'When do I get my credit back?' There is a photo of my brothers showing him the letter. (Interview, March 2014)

Thus, contrary to Jalal, Ali did not include his brothers into his business activities. Instead, he integrated first his close friends, ${ }^{27}$ and later, his children and affines into his strategies of capital creation. It is the analysis of the merchants' relations with their wives and children that the following paragraphs are concerned with.

\section{The (Image of the) Nuclear Family}

From the late 1940s, not just Ali, but also Jalal needed to fulfill the role of the father: Jalal's family had joined him in Hamburg. Soon, his wife Mahbubeh returned to Iran and the couple divorced, but his teenaged sons, Nima and Taghi, stayed with Jalal (Lankarany 2009, 24ff.). After a few years-Jalal was already in his late forties-he got to know Anna, a blonde and beautiful German model, by more than 20 years his junior. In 1952, they married and had a son, Mehran, and in 1955 a daughter, Solmaz.

By then, both Ali and Jalal had come to considerable wealth. But, as Bourdieu $(1985,725)$ argued, in order to claim upward social mobility, economic capital must be sustained by the acquisition of social and cultural capital relevant to the specific social field. Thus, beyond their economic activities, to generate such capital forms, the merchants invested,

\footnotetext{
${ }^{27}$ The reliance on-often multiplex-friendship ties has been observed as central to Pakistani entrepreneurs in Britain (Werbner 1990, 174ff.), as well as among Afghans of ethnic Hazara origin in Iran and Pakistan (Monsutti 2004, 226).
} 
first, in conspicuous consumption: both Jalal and Ali bought prestigious villas in upper-class districts, which they decorated with antique furniture, art, and craftwork. On the weekends, they went to a casino at the Baltic seaside resort Travemüde, ${ }^{28}$ and they drove expensive and rare cars. Ali took his family on holidays abroad, and Jalal bought a newly built prestigious nightclub (Lankarany 2009, 33, 48). Second, euergetism was another means both used to create capital: as mentioned earlier, Jalal would support his friends and family ${ }^{29}$ while Ali invested into the establishment of religious and social institutions for local Iranians. Conspicuous consumption and philanthropy had two purposes. On the one hand, following Aihwa Ong $(1999,92)$, they constituted an attempt to overcome barriers to capital creation they met in German social fields, that relate to their lack of Germany-specific capital or their construction as cultural and racial Other. On the other hand, similar to Pnina Werbner's (1990, 304ff.) observations among people of Pakistani origin in Manchester, such practices aimed at creating capital through the mediation of values such as trustworthiness, financial strength, and religious adherence within the social fields of Iranian merchants.

The nuclear family was mobilized for the generation of different forms of capital, while being at the same time the site of internal differentiation. Among the numerous possible instances that have been reported to me, social boundaries within the family are particularly evident in the organization of weekly receptions. ${ }^{30}$ Within the display of generosity which was at the core of these occasions, ${ }^{31}$ in Ali's family, each member had specific tasks, as Siavash explains:

\footnotetext{
${ }^{28}$ Ali despite being a practicing Muslim.

${ }^{29}$ For example, he financed the studies of a broke friend's sons (Lankarany 2009, 147).

${ }^{30}$ In line with their previously mentioned differences, according to Solmaz and Siavash, Jalal mainly invited family and friends while Ali hosted representatives from shipping and trading companies, members of associations he was involved in, Iranian and former German diplomats in Iran, as agents of German and Iranian banks.

${ }^{31}$ Beginning with Franz Boas' (1966, 77-104) study of the potlatch, there are numerous instances in anthropological studies showing that the staging of generosity, or ostentatious giving, serves to display wealth, create social capital, and thus negotiate social hierarchies. These practices were present also among both Hamburg's merchants (Evans 1991, 129) and bazaris in Iran (Keshavarzian 2007, 94).
} 
Siavash "Who busses the dishes? The two youngest. Sorush and I. We did not even dine with the guests but we came and went, dished up and bussed. And after the chicken broth, there was chelo kabâb [kebab with rice]. My mother delightfully knew how to prepare the meat beforehand. We had a Maghal, today that's called a barbecue, right, flown in from Iran. And then, we had a housekeeper from Bavaria... the old women always touched the red-hot coals with her bare hands! Ouch! Sepehr, as the oldest, had to grill."

Sonja "And Gita?"

Siavash "She ate with the guests. As a girl she had to... Or she helped mother fill up the rice." (Interview, July 2013)

Siavash's description points to how the nuclear family participated in these events in different ways, according to their position in the age hierarchy and their gender. In Jalal's family, the participation of the wife and children was less codified, certainly because, in contrast to Ali's family, it was characterized by many personal and geographical ruptures, but the main lines were similar.

Jalal's and Ali's wife passively and actively participated in their husband's creation of social capital. On the one hand, they displayed a certain prestige. Siavash told me that during these years, his mother was a "lady, she made an impression" (interview, July 2013). On the other hand, Emma reinforced multiplex relations with other merchant families, in joining regular meetings of other Iranians' (merchants') wives. ${ }^{32}$ Anna, too, showed herself as a caring and generous host, as Solmaz explains:

Even when I was little and I think also before I was born [Jalal] lived in a huge apartment where he also always had guests. My mother naturally had to help hosting all people, who sometimes moved in there for months. (Interview, July 2013)

Thus, similar to wives in British Pakistani families (Werbner 1990), Iranian merchants' wives represented the family's real or aspired social

\footnotetext{
${ }^{32}$ Such circles of female sociability that also exist in Iran, and in particular among bazaris (Keshavarzian 2007, 94), but have been observed among Iranians in London as well (Spellman 2004, 70ff.).
} 
position and contributed, through their socializing, to the generation of the family's resources and recognition thereof as capital.

Ali and Jalal both designated their oldest sons, Sepehr and Nima, to be their prospective heirs or at least to take over important responsibilities in the family business. They were sent to private boarding schools-in the light of the small number of such private colleges in the post-war era (Vogel 2005, 259), this aimed at drawing on the prestige of the school rather than as a long-term investment in higher education as, after their graduation, the fathers incorporated them into their businesses. From 1957, Sepehr, simultaneously worked and attended a commercial college in Hamburg. Nima graduated in 1951 and wanted to become a doctor, to what his father first agreed. Then, he changed his mind and forced Nima to do an apprenticeship as an instrument mechanic in Southern Germany. At the time, it was indeed customary among local German merchant families, that sons would first do an apprenticeship at a different company, sometimes even overseas, and only be raised as partners in the family business once they proved their capacities (Evans 1991, 127). As has become clear, Jalal and Ali exerted patriarchal authority to shape their wife's and children's image and actions in a way that sustained their strategies of capital creation. Significantly, Solmaz says about her father Jalal

...he was a typical Persian patriarch, strict and barely accessible for his children, much less than for his friends and other people who asked something from him or who needed his help. (Interview, July 2013)

Siavash also said that during meals his father always sat at the top end of the table and expected his children to hand him whatever he wanted only by looking at the object. Following the principle of filial piety, initially the children accepted their father's plans. Retrospectively, Nima remarks "Although I was self-confident otherwise, resistance was inappropriate for an Iranian son. You had to obey, it was as simple as that" (Lankarany 2009, 37).

Ali and Jalal also had plans for their younger sons: Siavash told me that, while Sorush was to be a businessman like Sepehr, he was supposed to become a captain. 
In fact, he sent his import-export goods with a Persian shipping company, and he said, perhaps he trusted an Iranian more than a German shipping company, but it would be much better still to have his son on the ship as a captain, in order for the wrong goods not to be transshipped in the wrong harbor [he laughs]. (Interview, March 2014)

Jalal, for his part, was not as meticulous in planning and integrating his children in his businesses as Ali, but he projected that his second and third sons Taghi and Mehran would become entrepreneurs. Generally, however, expectations and pressure did not weigh as heavily on the younger ones as it did than on the first-born sons.

The role of daughters was yet distinct. Both Ali and Jalal encouraged their daughters to work: while Gita did an apprenticeship as a secretary in Ali's company between 1957 and 1961, ${ }^{33}$ when Solmaz came of age in the early 1970s, Jalal wanted her to do what he had refused to Nima: study medicine. However, in everyday lives, Ali and Jalal monitored their daughters more closely than their sons.

Solmaz "Actually, I was allowed to have only few contacts to the outside. Female friends some, but I had to ask permission if I wanted to leave the house."

Sonja "Really? That strict?"

Solmaz "Yes. I had to be at home at eight [o'clock] sharp. At eight sharp the Tagesschau [news] starts. If I arrived later, I got into terrible trouble. Then, there were curfews. He was really terrible in this regard." (Interview, July 2013)

Gita was not as explicit in her description of the father's control over her everyday life. As we shall see later, she had her own conflicts with him, but also enjoyed some protection from her mother that Solmaz lacked. The increased attention to the daughters' (sexual) life serves to guarantee the family's collective capital creation: in Iranian as in many other contexts, and in particular within the tight social networks of merchants, the

\footnotetext{
${ }^{33}$ In Iran, the bazar was a male dominated area (Keshavarzian 2007). In Germany, at that time, it was a common sign of wealth among German merchants for women not to work (Ziegler 2000, 28). It was therefore probably the shortage of trustworthy employees that led Ali to have Gita do an apprenticeship.
} 
family's honor-her reputation-had (and still may have) an important influence on their kin's possibilities of gaining acknowledgment for their resources as capital (Bromberger 2003, 87).

In sum, having a wife and children in Hamburg came to play a crucial role in Jalal's and Ali's strategies of capital creation. On the one hand, the men used their wife and children to display economic, cultural, and social resources and claim recognition for them as a capital. Even the image of the family itself can generate capital: in founding a family Jalal and Ali stressed their availability to establish long-term business relations in Hamburg. On the other hand, the merchants also delegated capital creation to their children in practices Ong $(1999,118)$ calls "family governmentality". Based on the idea of a common interest in the family business, heads of family arrange or promote, through the exercise of patriarchal authority, educational, professional, and migratory trajectories; physical appearance; and, as we shall see, marriage alliances in order to circumvent legal and bureaucratic limitations posed by nation-states. The professional and private roles and opportunities the merchants' children were thus attributed depended on their age, gender, and place in the birth hierarchy. As they grew older, these differentiations within the family were renegotiated.

\section{Dissent, Death, Disruptions}

Just as trust in kinship relations can be very beneficial to business success, it can also be the cause of failure (Werbner 1990, 75f.), namely, when intersubjective conflicts lead to voluntary disruptions. Jalal had to learn this the hard way. It all began when his wife Anna left him in 1959, after seven years of marriage. Solmaz explained that her mother could not suffer Jalal's year-long stays in Iran. Moreover, she experienced rejection from his mother and sisters. Just as in his business strategies, outraged Jalal relied on transnational family ties to resolve the situation. According to Iranian family law, custody falls to the father. Consequently, he took Mehran and Solmaz to Tehran to be fostered by his mother and sisteran experience Solmaz describes as traumatic. He did not allow them to 
see their mother again until 1967. One year later, in 1961, Jalal married his third wife, Taraneh, a widow from Rasht who had three sons- the youngest of whom was Mehran's age. The newly composed family moved into the villa in Hamburg together.

In 1962, Jalal's brother Khosro accused him of mismanaging the company and claimed the right to buy his shares from both the factory in Iran and the import-export business in Hamburg. The factory had been passing through a rough patch. Jalal had declined a request of the royal Pahlavi foundation to buy shares, which had resulted in the government opening the market to foreign competitors. Plus, according to his children, Jalal lost financial resources as he tended to give more to his friends and trade partners than he received in return (Lankarany 2009, 146). Thus, the brothers relied on the same resources while their strategies of capital creation began to diverge; rivalry and competition developed. They made an oral agreement according to which Khosro paid Jalal a severance as well as a monthly appanage. When, after ten years, Khosro stopped the monthly payments, Jalal had no means to claim his allowance (Lankarany 2009, 145-49). The former merchant went bankrupt and the two brother's families permanently broke all their ties. ${ }^{34}$ According to Solmaz, the conflict divided the loyalties of the transnational family. Other Iranian merchants in Hamburg tried to reconcile the brothers, in vain. While Jalal died impoverished in 2002 at the age of 98 while trying to maintain the illusion of wealth, ${ }^{35}$ Khosro remained wealthy until his death in 2015. Jalal's social decline, well remembered by merchants who had known him, certainly augmented his expectations concerning the professional trajectories and marriages of his children, which were however, in Solmaz' words, "deceived":

It actually did not work out as he had imagined for any of his children. My father's siblings are all quite well off I think, but nobody of us, his children, did what he had fancied he'd do. Thus, [we were] all losers, in a way, in his view [she laughs]! (Interview, July 2013)

\footnotetext{
${ }^{34}$ Except for Nima, who took sides for Khosro and against his father for some more time.

${ }^{35}$ A strategy that had been observed among downwardly mobile Iranians in Los Angeles (Kelley 1993).
} 
Nima failed a study program in which he had enrolled. Then, he refused the marriage Jalal arranged for him with a young woman from another merchant family living in Iran. Instead, he entered a business school and married his German girlfriend. Jalal even bribed the Iranian consul in Hamburg to impede on this marriage, unsuccessfully (Lankarany 2009, 41-51). His second son, Taghi, returned to Tehran in the early 1950 s (Lankarany 2009, 36-51), but he never became successful with his business projects. He is the only one of Jalal's biological children who married an Iranian, but the couple divorced later and Taghi moved to California where he died of surgical complications in early 2010. His children remained in Iran and his daughter married an Iranian. Nima's and Mehran's children remained in Germany and the only marriage among them is with a German. Mehran, the third son, graduated with a PhD in Iranian Studies in 1983, and only later followed the father's idea in funding a modest merchant business. Solmaz resisted Jalal's plan for her to study medicine. In 1973, she dropped out of school whereupon he evicted her from the family home. During many years, she made a living with unskilled jobs, until she became a foreign language correspondent clerk. She never funded a family. Thus, one by one, Jalal's children dropped out of the roles Jalal had assigned them to in his flexible capital creation. ${ }^{36}$

Compared to Jalal, Ali was more successful in realizing his plans: his marriage remained intact, his first-born Sepehr worked in his company and moved to Iran in 1967 for a marriage Ali had arranged for him with the daughter of a successful entrepreneur. He founded a new business with his father-in-law in Iran, which aimed at saving the ailing family business. Ali's younger sons negotiated professional trajectories that slightly deviated from his original idea, but that did not cause major relational issues. All was good-if it was not for his daughter Gita. While Ali tried to marry her to a young Iranian business partner established in Tokyo, Gita became engaged to her Spanish teacher-who was a German and a practicing Catholic. Acting against Ali, Gita left the family enter-

\footnotetext{
${ }^{36}$ Jalal probably did not include Taraneh's three sons in his strategies of capital creation. Significantly, Solmaz called her half-brothers "brothers", while she named her step-brothers by their accurate term (Stiefbruder).
} 
prise in 1962, when she was 24 years old, and worked as a secretary in Barcelona. "I won't let them marry me off?" (interview, March 2014), she comments in retrospect. Only Emma, her mother, attended Gita's wedding two years later. Ali had probably convinced his sons to participate in a collective punishment for this transgression. Solmaz also used an intimate relationship to defy her father's patriarchal control: as a teenager, she engaged in a seven-year relationship with her youngest step-brother. It becomes clear that marriage alliances, in particular for their first-born sons and their daughters, were an important tool for Ali and Jalal to diversify their resources and generate new capital among Iranian merchants. Deviations from these arrangements were thus often met with drastic renegotiations of kinship relations. The fact that neither Ali nor Jalal encouraged their children to marry a German-let alone to marry into a German merchant family-is emblematic of their ongoing concentration on capital creation in transnational rather than local social fields, even 20 years after their immigration.

The examination of the practice of kinship in the context of flexible transnational capital creation reveals an issue that Aihwa Ong (1999) did not consider, due to her focus on the ways filial and conjugal piety sustained the patriarch's "family governmentality": what happens to the collective project of flexible capital creation if kin defy the roles they were assigned to by their head of family? Two aspects may account for these intersubjective conflicts between the merchants and their children. First, the children's defiance is an expression of the fact that they developed values — and resources — that diverge from those of their fathers. Growing up in Germany, they were shaped by a society where, in the course of the post-war economic expansion, individualism increasingly took precedence over collectivist conceptions and women rights movements questioned patriarchalism (Attias-Donfut 2000, 663). These influences nourished their questioning the parents' conception of gender and generational hierarchies (Zontini 2009, 824f.). In her study of Chinese merchant families in Tahiti, Anne-Christine Trémon (2017) also indicates that the values and family's collective strategies of flexible capital creation may shift with changing socio-economic and cultural contexts. Siavash comments accordingly: 
With that humanistic education I was very far away from my father's world. That's how a family drifts apart. Father said "We are Iranians, we go back." For me that wasn't even up for debate anymore. In school there was no other Iranian [...], and, although I had one or two Iranian friends, for me this never implied an integration into the Iranian colony in a narrower sense. (Interview, July 2013)

These negotiations within the transnational family, which Bryceson and Vuorela (2002) call "frontiering", led, in the case of Ali's relation with his younger sons, to minor mutual adjustments that allowed to maintain the original project, not least thanks to the first-born's compliance with his own role.

Second, the more dramatic voluntary disruptions in Jalal's family (Nima and Jalal severed contact for decades) may be traced back to deception deriving from a disequilibrium in relations of exchange (see also Zontini 2009). For the (financial) support the father offered, he expected his children in return to play the part he had assigned them to in his strategies of capital creation. However, the pressure of Jalal's expectations, combined with an often unfulfilled need of financial, and, more importantly, emotional support-accentuated by the absence of a caring mother ${ }^{37}$ (Attias-Donfut 2000, 673) —led the children to resign from an exchange which they experienced as a poisoned gift (Mauss 1966).

As a consequence of this dissent, Jalal's rebelling kin disengaged from the collective project of flexible capital creation and invested new social fields in which they follow their own strategies of capital creation. Their individualization resulted in a loss of important resources for the family business. His children each began to fend for themselves. In the early 1970s, Nima and Taghi's resources were unavailable, unapt, or insufficient to prevent Jalal's bankruptcy. Furthermore, these disruptions durably destabilized their practices of kinship. While some of the children tried to negotiate new terms to their relation with Jalal, repeated conflicts among the siblings, not least about financial issues, prevented them from recreating a collective project of capital creation.

\footnotetext{
${ }^{37}$ Solmaz described her step-mother Taraneh was rather severe.
} 
Beyond voluntary disruptions, there are also the involuntary ones. In 1969, Ali died of a stroke due, as his children suspect, to impending bankruptcy that has affected his enterprise. Michael Lambek (2011) reminds us that death represents a moment of disruption in which differentiation within the family may be renegotiated. The sudden death of the father coinciding with financial failure indeed led to a period of internal restructuration in the family, as Siavash remarks:

Such a family, as it's common among Persian families, is very much based on the head of family, and when he drops out then the whole barn falls apart, right? (Interview, July 2013)

Emma, who lost all financial resources, broke with her old role as a family mother, worked as a nanny in Southern Europe for many years, and never reinvested in Iranian social fields again until her death in 1999. As the formal successor, Sepehr took over Ali's highly indebted company, but lost it together with his businesses in Iran in the context of the Islamic revolution in 1979. Two marriages with women in Iran ended in divorce. Finally, he settled with a Mexican woman and made a modest living as a carpet retailer in Eastern Germany before the couple moved to Florida where he collaborates in a real estate business with Sorush. Indeed, it was his younger brother who ended up continuing the father's professional heritage. Sorush became a multimillionaire with an international real estate agency he founded in 1971, whose premises in Hamburg are just next to where Ali's office was. Also, after a first union with an Iranian based in Austria, he married the member of a well-established Hamburg merchant family as if to strengthen Germany-specific capital. The family moved to Canada and then settled in Switzerland. Meanwhile his first daughter reinvested Hamburg's Iranian social fields and married the son of a local Iranian businessman of Baha'i faith ${ }^{38}$ in 2013. In his own way, Sepehr's son also carries on the family history as a maritime engineer, and his first daughter's two marriages were with Iranians based in the USA. Siavash moved to work as a geologist in the north German

\footnotetext{
${ }^{38}$ The Baha'i faith is a monotheistic religion that developed in the nineteenth century in Iran - a religion high Islamic clerics did not recognize and condemned, even at the time of Sorush's marriage (Brookshaw and Fazel 2008).
} 
countryside, married a local, and adopted a son from Nepal. Gita lived with her family in the south of Germany until she divorced and returned to Hamburg while her two sons live in other German cities.

Thus, after Ali's death, his wife and children developed individually different strategies of capital creation, and certain marriage alliances and religious choices led to disagreements within the nuclear family. Yet, however great the differences between Ali's children were, in contrast to Jalal's children, they still create capital together. For example, Siavash organized Gita's move to a retirement home in 2015, and he wrote an article in a German travel magazine indirectly making publicity for Sorush's business. Sorush, on his part, supports Siavash's cemetery project, and shared his wealth, for example, in inviting the whole family for yearly holidays. Thus, in a dynamic Trémon (2017) calls "flexible kinship", despite disruptions, Ali's children redefined and revived the collective flexible capital creation that Ali initiated in the transnational social field of Iranian merchants in new forms and in different social fields.

\section{Descendants' Positioning Toward Iranians Today}

While changing values, inequality of exchange, and death led to voluntary and involuntary disruptions within the family and to the individualization of kin's strategies of capital creation, these events also had an important impact on the way the merchants' children engage with other Iranians in Hamburg, in Iran, or elsewhere. The two factors by which they explained their contemporary positionalities was, on the one hand, their father's financial decline, and on the other hand, their experience of the practice of kinship as a child and their experience of kinship practice.

Ali had been particularly engaged in financing the building of infrastructures for the local Iranian Shia community. Therefore, his children told me that they were disappointed by their father's local Iranian colleagues and friends when they faced financial hardship. Sepehr told me that

after father's death, ties with Iranians broke. Even those who said at his tomb "Call on us if you need anything" never contacted us again. Although father did so much [for them]. (Field notes, July 2013) 
Interestingly, Ali's first-born does not limit the experience of difficulties in capital creation among Iranian merchants to this particular social field. In our interview, Sepehr, who speaks German with an American accent, tells me "that he does not get along well with Iranians, with ta'ârof [the Iranian code of politeness]. That would not be much like him" (field notes, July 2013). Thus, he creates a boundary, distancing himself from his Iranian heritage. In doing so, he indirectly explains his failure in creating capital in Iranian merchants' transnational social fields by his ethnic difference. What is the relation between experiences of kinship, Iranian identifications, and the engagement in Iranian transnational social fields?

His youngest brother Siavash chose to set aside his Iranian identifications much earlier, after Ali's death. Commenting on his early time in a village close to Göttingen, in Lower Saxony, he said:

When I moved here, to the countryside, and worked for a public service the foreign was rather secondary, right? Other people approached me with it, but I didn't make anything out of it myself. (Interview, July 2013)

Thus, Siavash's identification as German aimed at generating capital in local German social fields. Significantly, he married a German of Christian faith. However, his comment shows that these identifications met the resistance of Germans who continued to construct him as ethno-racial "Other". It was only when Siavash was in his early fifties — maybe as a reaction to the experience of being categorized as foreigner-that he engaged in relations with Iranians and other Muslims, as he renewed adherence to Islam. Building on the capital his father had created through charity work today, he is more involved in Iranian social fields than his siblings. For instance, he created an association for the maintenance of the Iranian lot of the local cemetery that had been created by Ali in 2017. His memory of failed support from Iranians after Ali's death may have been gradually superseded by Iranian merchants' and mosque clerks' appreciation for the father's engagement for the Iranian Shia community and its infrastructure.

As shown in the introduction, research on transnational social fields highlights the importance of migration- and location-specific resources for migrants' capital creation in diverse social fields (Erel 2010; Cederberg 2015). Among Iranian merchants, to create capital Sepehr needed to 
have Iran-specific resources such as speaking Persian or Azari or knowing ta'ârof in order to create capital. Conversely, in the social fields located at the North German countryside where Siavash lived, he needed Germanyspecific resources to create capital. The ethnographic material presented here, however, allows to extend the perspective on the men's strategies of capital creation by their experience of filial and affine relations in the context of collective flexible capital creation.

Solmaz' comment offers a key to this understanding of the triangle of kinship, Iranian identity, and capital creation. While she also remembers the hurt of her family's downward social mobility, it is by her experience of her role in kinship relations that she explains the way she engages with other Iranians:

For me, [anything Iranian] was a real system of oppressors, right? At the time, it didn't have the quality of a culture, or something beautiful, or so, but it really was a symbol of total oppression, and I simply had a total desire of freedom. When I moved out I wished, virtually, to be a German, I mean, I did not want to have anything to do with Iran. (Interview, July 2013)

After she broke with her father over her professional trajectory, she distanced herself from her family as well as from other Iranians for about 30 years and replaced her Iranian by a German citizenship. Her comments highlight what was subjacent in Sepehr's and Siavash's statements: the identification of the experience of kinship with anything Iranian. The association is reminiscent of the constructed dichotomies of nature and culture, the biological and the social, in particular in the context of kinship and ethno-racial differentiation (Strathern 1992; Wade 2007). It reminds us of the newspaper article cited in the introduction that showed that the children were hegemonically constructed as Iranians by the German legislation and by social discourses. We saw that different, yet similar structural limitation was imposed on them by their father's family governmentality and ongoing efforts to integrate them into their flexible capital creation in Iranian transnational social fields.

Strikingly, however, the diachronic perspective shows that the memory or experience of kinship practices and the resulting strategies of capital creation are not fixed, but underlie temporalities; they change within the 
life course (Trémon 2017). Thus, similar to Siavash, it is Solmaz who, among the siblings, is closest to other Iranians, as she recently renewed contacts with some members of her extended family, occasionally goes to Iranian cultural events, and regularly visits a friend of her father who is still alive. She told me that, for the first time since 1974, she considers traveling to Iran. My encounter with them itself, their participation in this research and our discussion of an earlier version of this chapter is both an important testimony and element within this renewed interest of theirs.

In sum, the ethnographic material indicates that there is a triangular relationship between kinship, entangled ethnic, racial, or national identifications and strategies of capital creation. In other words, not only the positionalities migrants take within in-group relations and the ethnic and national identifications they put forward are interrelated; both strongly correlate with changing personal experiences of kinship practices.

In this chapter, I traced the ways two merchants mobilized kin to generate capital along conceptions of generation, gender, and age in order to explain how these experiences influence the descendants' own national identifications and their positionalities in local and transnational social fields constituted mainly by Iranians. Similar to the dynamics within the well-established Northern-German merchant family described in Thomas Mann's (1993 [1901]) chronicle The Buddenbrooks, Iranian merchants involved their siblings and children in their flexible capital creation in their professional transnational social fields.

As I trace the personal trajectories of kin over two generations, I go beyond Aihwa Ong's (1999) premise of filial piety, showing how voluntary and involuntary disruptions of kinship relations impact on collective flexible capital creation. While involuntary disruption through death or the flexible adaption of kinship to the members' changing values or sociolegal condition may result in the transformation of the collective project, voluntary disruption based on mutual deceptions may favor its dissolution and the individualization of strategies of capital creation.

I showed that, in a triangular relationship, the changing experience of kinship has a lifelong influence on migrants' engagement in social fields mainly constituted by Iranians as well as on their national identifications. I thus argue for a greater consideration of processes of "doing kinship" 
and historically informed approaches both in the study of migrants' internal differentiation and transnational capital creation.

Having closely examined professional trajectories of two merchants, in the next chapter my interest shifts to larger social contexts, as I look at the way carpet merchants of Iranian origin developed collective strategies of capital creation and how they influence social boundary-making among Hamburg's Iranians today.

\section{References}

Abelshauser, Werner. 2004. Deutsche Wirtschaftsgeschichte seit 1945. München: C.H. Beck.

Abrahamian, Ervand. 1982. Iran Between Two Revolutions. Princeton: Princeton University Press.

- 2008. A History of Modern Iran. Cambridge: Cambridge University Press. Adli, Abolfazl. 1960. Außenhandel und Außenwirtschaftspolitik des Iran. Berlin: Duncker \& Humblot.

Attias-Donfut, Claudine. 2000. Rapports de générations. Transferts intrafamiliaux et dynamique macrosociale. Revue française de sociologie 41: 643-684.

Aumüller, Jutta. 2009. Assimilation: Kontroversen um ein migrationspolitisches Konzept, Kultur und soziale Praxis. Bielefeld: transcript Verlag.

Azimi, Fakhreddin. 2008. The Quest for Democracy in Iran: A Century of Struggle Against Authoritarian Rule. Cambridge/London: Harvard University Press.

Baldassar, Loretta, and Laura Merla. 2014. Locating Transnational Care Circulation in Migration and Family Studies. In Transnational Families, Migration and the Circulation of Care: Understanding Mobility and Absence in Family Life, ed. Loretta Baldassar and Laura Merla, 25-59. New York/ Abington: Routledge.

Boas, Franz. 1966. Kwakiutl Ethnography. Chicago: University of Chicago Press. Bourdieu, Pierre. 1985. The Social Space and the Genesis of Groups. Theory and Society 14 (6): 723-744. https://doi.org/10.2307/657373. . 1990. The Logic of Practice. Stanford: Stanford University Press.

Bromberger, Christian. 2003. Iran, les temps qui s'entrechoquent. La pensée 333: 79-94.

2005. Famille et parenté dans la plaine de Gilan (Iran). In Famille et Mutations Sociopolitiques: L'approche culturaliste à l'épreuve, Colloquium, ed. Azadeh Kian-Thiébaut and Marie Ladier-Fouladi, 125-142. Paris: Editions de la maison des sciences de l'homme. 
2013. Un autre Iran: Un ethnologue au Gilân. Paris: Armand Colin. Brookshaw, Dominic Parviz, and Seena Fazel. 2008. The Baha'is of Iran: SocioHistorical Studies, Routledge Advances in Middle East and Islamic Studies. New York/Abington: Routledge.

Brubaker, Rogers. 2001. The Return of Assimilation? Changing Perspectives on Immigration and Its Sequels in France, Germany, and the United States. Ethnic and Racial Studies 24 (4): 531-548. https://doi. org/10.1080/01419870120049770.

Bryceson, Deborah, and Ulla Vuorela. 2002. Transnational Families in the Twenty-First Century. In The Transnational Family: New European Frontiers and Global Networks, ed. Deborah Fahy Bryceson and Ulla Vuorela, 3-30. Oxford: Berg Publishers.

Cederberg, Maja. 2015. Embodied Cultural Capital and the Study of Ethnic Inequalities. In Migrant Capital: Networks, Identities and Strategies, Migration, Diasporas and Citizenship, ed. Louise Ryan, Umut Erel, and Alessio D’Angelo, 33-47. Hampshire/New York: Palgrave Macmillan.

Conway, Dennis, and Jeffrey H. Cohen. 1998. Consequences of Migration and Remittances for Mexican Transnational Communities. Economic Geography 74 (1): 26-44. https://doi.org/10.1111/j.1944-8287.1998.tb00103.x.

Curtin, Philip D. 1984. Cross-Cultural Trade in World History. Cambridge/New York: Cambridge University Press.

Digard, Jean-Pierre, Bernard Hourcade, and Yann Richard. 2007. L'Iran au XXe Siècle: entre nationalisme, Islam et mondialisation. Paris: Fayard.

Einbock, Sebastian. 2015. Deutsche Staatsangehörigkeit. Jura Forum. http:// www.juraforum.de/lexikon/deutsche-staatsangehoerigkeit\#Vorschriften_ aus_der_Gesetzgebung_bis_2000. Accessed 14 Apr.

Erel, Umut. 2010. Migrating Cultural Capital: Bourdieu in Migration Studies. Sociology 44 (4): 642-660. https://doi.org/10.1177/0038038510369363.

Evans, Richard J. 1991. Family and Class in the Hamburg Grand Bourgeoisie 1815-1914. In The German Bourgeoisi, ed. Richard J. Evans and David Blackbourn, 115-139. London/New York: Routledge.

Ewert, Ulf Christian, and Stephan Selzer. 2009. Commercial Super Trust or Virtual Organisation? An Institutional Economics Interpretation of the Late Medieval Hanse. Presented at the Eighth European Historical Economics Society Conference, Geneva, September 4.

Ewert, Ulf Christian, and Marco Sunder. 2011. Trading Networks, Monopoly and Economic Development in Medieval Northern Europe: An Agent-Based Simulation of Early Hanseatic Trade. Presented at the 9th European Historical Economics Society Conference, Dublin, September 2. http://www.wifa.uni- 
leipzig.de/fileadmin/user_upload/iew-vwl/Docs/Sunder/Ewert_ Sunder_EHESC.pdf

Fewkes, Jacqueline H. 2009. Trade and Contemporary Society Along the Silk Road: An Ethno-History of Ladakh, Routledge Contemporary Asia Series. New York/ Abington: Routledge.

Goffman, Erving. 1990. The Presentation of Self in Everyday Life. London, New York, Victoria, Toronto, New Delhi, Auckland, Johannesburg: Penguin Books. Dr. Gropp, Gert, and Ramin Shaghaghi. 2009. Ein hanseatisch-persischer Handelsvertrag aus Istanbul von 1842. In Strukturelle Zwänge - Persönliche Freiheiten: Osmanen, Türken, Muslime: Reflexionen zu gesellschaftlichen Umbrüchen. Gedenkband zu Ehren Petra Kapperts, ed. Hendrik Fenz, 183-210. Berlin: Walter de Gryter GmBH \& Co.

Keddie, Nikky. 2006. Modern Iran: Roots and Results of Revolution. New Haven: Yale University Press.

Kelley, Ron. 1993. Ethnic and Religious Communities from Iran in Los Angeles. In Irangeles: Iranians in Los Angeles, ed. Ron Kelley, Jonathan Friedlander, and Anita Colby, 81-161. Berkeley/Los Angeles/Oxford: University of California Press.

Keshavarzian, Arang. 2007. Bazaar and State in Iran: Politics of the Tehran Marketplace. Cambridge: Cambridge University Press.

Keyaniyan. 2014. Kaufleute seit Generationen. Keyaniyan Company GmBH. http://www.keyaniyan.de/historie.html. Accessed 14 Oct.

Kuper, Adam. 2004. The Social Anthropology of Radcliffe-Brown, Routledge Library Editions, Anthropology and Ethnography. London/Henley/Boston: Routledge \& Kegan Paul LTD.

Lambek, Michael. 2011. Kinship as Gift and Theft: Acts of Succession in Mayotte and Israel. American Ethnologist 38 (1): 2-16. https://doi. org/10.1111/j.1548-1425.2010.01288.x.

Lankarany, Hossein. 2009. Der Blaue Puppenwagen: Erlebnisse Zwischen Okzident Und Orient. Bremen: Donat Verlag.

Mahrad, Ahmad. 1979. Die Wirtschafts- Und Handelsbeziehungen zwischen Iran und dem nationalsozialistischen Deutschen Reich. Anzali: Gilan-Publikation.

Mann, Thomas. 1993. Buddenbrooks: The Decline of a Family. New York/ Toronto: Random House.

Massey, Douglas S., Joaquín Arango, Hugo Graeme, Ali Kouaouci, Adela Pellegrino, and J. Edward Taylor. 1998. Worlds in Motion: Understanding International Migration at the End of the Millennium. Oxford: Oxford University Press. 
Mauss, Marcel. 1966. The Gift: Forms and Functions of Exchange in Archaic Societies. London: Cohen \& West Ltd.

Moghadam, Amin. 2013. De l'Iran imaginé aux nouveaux foyers de l'Iran: Pratiques et espaces transnationaux des Iraniens à Dubaï. Arab Humanities [En Ligne] 2: 1-20.

Moghaddari, Sonja. 2015. Migrations et modernités iraniennes: Les familles transnationales. Paris: Editions du cygne.

Monsutti, Alessandro. 2004. Cooperation, Remittances, and Kinship among the Hazaras. Iranian Studies 37 (2): 219-240.

- 2005. War and Migration: Social Networks and Economic Strategies of the Hazaras of Afghanistan, Middle East Studies: History, Politics, and Law. New York/London: Routledge.

2011. Au-delà de l'ethnicité et de la parenté en Afghanistan: Une approche ethnographique des liens transversaux de coopération. Cahiers d'Asie Centrale 19-20. http://asiecentrale.revues.org/1414

Mousavian, Seyyed Hossein. 2008. Iran-Europe Relations: Challenges and Opportunities, Durham Modern Middle East and Islamic World Series. London: Routledge.

Nayyeri, Mohammad Hossein. 2013. Gender Inequality and Discrimination: The Case of Iranian Women. Iran Human Rights Documentation Center, August 3. http://iranhrdc.org/english/publications/legal-commentary/ 1000000261-gender-inequality-and-discrimination-the-case-of-iranianwomen.html\#9

Ong, Aihwa. 1999. Flexible Citizenship: The Cultural Logics of Transnationality. Durham: Duke University Press.

Sahlins, Marshall. 1972. Stone Age Economics. Chicago: Aldine Atherton. . 2013. What Kinship Is - And Is Not. Chicago/London: The University of Chicago Press.

Sana, Mariano, and Douglas S. Massey. 2005. Household Composition, Family Migration, and Community Context: Migrant Remittances in Four Countries. Social Science Quarterly 86 (2): 509-528. https://doi. org/10.1111/j.0038-4941.2005.00315.x.

Schneider, David M. 1984. A Critique of the Study of Kinship. Ann Arbor: The University of Michigan Press.

Spellman, Kathryn. 2004. Religion and Nation: Iranian Local and Transnational Networks in Britain. Oxford: Berghahn Books.

Strathern, Marylin. 1992. After Nature: English Kinship in the Late Twentieth Century, Lewis Henry Morgan Lectures. Cambridge/Melbourne: Cambridge University Press. 
2014. Kinship as a Relation. L'Homme 210: 43-61.

Sywottek, Arnold. 1986. Hamburg seit 1945. In Hamburg: Geschichte der Stadt und ihrer Bewohner, Band II Vom Kaiserreich bis zur Gegenwart, ed. Werner Jochmann, 377-466. Hamburg: Hoffmann und Campe.

Tapper, Richard. 1979. Pasture and Politics: Economics, Conflict and Ritual Among Shabsevan Nomads of Northwestern Iran. London: Academic Press.

Trémon, Anne-Christine. 2017. Flexible Kinship: Shaping Transnational Families Among the Chinese in Tahiti. Journal of the Royal Anthropological Institute 23 (1): 42-60. https://doi.org/10.1111/1467-9655.12543.

Tsutomu, Sakamoto. 2013. Trading Networks in Western Asia and the Iranian Silk Trade. In Commercial Networks in Modern Asia, ed. Linda Grove and S. Sugiyama, 235-250. New York/Abington: Routledge.

Van, Rachel Tamara. 2011. Free Trade \& Family Values: Kinship Networks and the Culture of Early American Capitalism. New York: Columbia University.

Vladi, Firouz. 2004. Das Leben des Hassan Vladi. Ein frühes Beispiel für Migration und Integration aus Hamburg. Die Brücke: Forum für antirassistische Politik und Kultur 1 (131): 96-100.

. 2014. Blanka Sophie Dora Elise Hartmann Geb. Moritz: Nachruf auf unsere Liebe Oma, Großmutter und Urgroßmutter. Unpublished Manuscript.

Vogel, Regina. 2005. Bürgerliche Werte und Statuserhalt: Bildungspolitische Interessenpolitik von Hochschullehrer- und Unternehmerverbänden in der Nachkriegszeit. Berlin: Humbolt-Universität. http://edoc.hu-berlin.de/dissertationen/vogel-regina-2005-02-01/PDF/vogel.pdf

Wade, Peter, ed. 2007. Race, Ethnicity and Nation: Perspectives from Kinship and Genetics, Berghahn Series. New York/Oxford: Berghahn Books.

Werbner, Pnina. 1990. The Migration Process: Capital, Gifts and Offerings Among British Pakistanis. New York/Oxford/Munich: Berg Publishers.

Wubs-Mrozewicz, Justyna. 2013. The Hanse in Medieval and Early Modern Europe: An Introduction. In The Hanse in Medieval and Early Modern Europe, ed. Justyna Wubs-Mrozewicz and Stuart Jenks, 1-25. Leiden/Boston: Brill. Ziegler, Dieter. 2000. Die Wirtschaftsbürgerliche Elite im 20. Jahrhundert: Eine Bilanz. In Großbürger und Unternehmer. Die Deutsche Wirtschaftselite im 20. Jahrhundert, ed. Dieter Ziegler, 7-29. Göttingen: Vandenhoeck \& Ruprecht. Zontini, Elisabetta. 2009. Enabling and Constraining Aspects of Social Capital in Migrant Families: Ethnicity, Gender and Generation. Ethnic and Racial Studies 33 (5): 816-831. https://doi.org/10.1080/01419870903254661. 
Open Access This chapter is licensed under the terms of the Creative Commons Attribution 4.0 International License (http://creativecommons.org/licenses/ by/4.0/), which permits use, sharing, adaptation, distribution and reproduction in any medium or format, as long as you give appropriate credit to the original author(s) and the source, provide a link to the Creative Commons licence and indicate if changes were made.

The images or other third party material in this chapter are included in the chapter's Creative Commons licence, unless indicated otherwise in a credit line to the material. If material is not included in the chapter's Creative Commons licence and your intended use is not permitted by statutory regulation or exceeds the permitted use, you will need to obtain permission directly from the copyright holder.

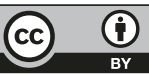




\section{Narrating "Traditional Iranian Carpet Merchants"}

In 1968, Farhad F. settled in Hamburg's free port as an importer and specialist for hand-knotted carpets, perpetuating the tradition of the carpet trade in the second generation. Today, the branch in Hamburg's Speicherstadt, with its $1000 \mathrm{~m}^{2}$ show room, is managed mainly by the third generation. We offer a large assortment of hand-knotted carpets. (Section "company" on a merchant house's website, anonymized, translation by the author)

A photo of four people, presumably a family, accompanies this text. Before the decorative background of a warehouse with piles of oriental carpets, the husband and wife, in their fifties, are positioned on the left side of the picture and the son and daughter, in their early twenties, on the right. The two men wear costumes in dark colors with white shirts and shiny beige and blue ties, sporting confident toothy smiles. The son's left hand is in his pocket, demonstrating effortless assurance. The women, instead, display a retained smirk, wearing a blazer and a pullover with a fur-trimmed collar. The mother also wears full hijab that covers her neck and hair, while the daughter's long, dark hair is tied back. The image twines generational continuity with familial unity through similar 
postures. Gender roles appear to be shaped by patriarchal and Islamic principles, as they show in the men's élan and the women's modest demeanor and dress. The photo reminds me of the pictures of Ali's family in Chap. 2. It puts forward an Iranian identification, family cohesion, a long history in Hamburg as proof of business continuity and expertise, and (in this case) also religious adherence.

As I got to know more and more Iranian carpet merchants during my fieldwork, I was struck by the observation that, although their business strategies may be quite diverse, they offer very similar identitary discourses both in immediate contact with me and in their media publications. The above online presentation of a merchant family business contains its main elements. How did this collective narrative develop?

Resources that sustain an ethnic or national identity may be useful for avoiding barriers to capital creation in the social fields related to the country of residence, as they allow migrants to withdraw from the main labor market (Moallem 2000; Bauder 2005). Otherwise, through "identity entrepreneurship" (Brubaker and Cooper 2000; see Erel 2010; Nowicka 2013), these resources can serve to create capital within social fields of the society of residence. Research that traces such practices in transnational contexts largely focuses on the practicalities of migrants' juggling resources across social fields. Yet, what motivates their strategies of capital creation? Considering, with Joel Robbins $(2015,28)$, that social actions is, in complex and sometimes contradictory ways, motivated by values, I draw on the anthropology of value to answer this question. In the introduction to this book, I argue that capital creation relies on evaluation processes; evaluation processes take place in historically rooted hierarchical systems of value (Graeber 2001). The notion of value thereby refers to "ideas about what is ultimately important in life" (idem 2013, 224). Although extant research on migration reveals the evaluation of migrants' resources in the society of residence, we know very little about the way systems of value interrelate within and across different social fields. Ultimately, what is migrants' potential for action within the diverse, partly contradictory systems that define the value of their resources?

Omid, the 60-year-old merchant and president of the Association of Iranian Carpet Importers in Europe (AICE), followed his merchant 
father to Hamburg as a teenager, in 1968, and speaks German with a local vernacular. In the late 1970 s, he sometimes played football with the later president of the Islamic Republic, Mohammad Khatami, after his Quran class, who at the time served as an imam at the local Imam Ali mosque. According to the father of two young adults who also work in the family business, Hamburg currently counts about 37 carpet merchant enterprises. In 1992, there were 319. They still largely outnumber their colleagues trading dried fruits, nuts, and caviar-some of the few Iranian goods which are legally tradable after the enforcement of international sanctions. Despite their dwindling number, their activities became ever more crucial due to Iran's marginalization in the global economic and political landscape. Hamburg-based Iranian carpet merchants are transnational entrepreneurs, that is

social actors who enact networks, ideas, information, and practices for the purpose of seeking business opportunities or maintaining businesses within multiple social fields, which in turn forces them to engage in varied strategies of action to promote their entrepreneurial activities. (Drori et al. 2010, 4)

In Chap. 2, I demonstrated that they flexibly adapt their strategies of capital creation to changing socio-economic and legal conditions across national borders (Ong 1999). The analysis of kinship relations within the entrepreneurial family showed that individual ethnic and national identifications are both tools and expressions of strategies of capital creation within contexts of structural limitations deriving from unequal power relations. In this chapter, I analyze Iranian merchants' collective identitary narrative as a tool in and a reflection of transnational capital creation and problematize transnational capital creation as part of migrants' creative engagement with systems of value.

Building on participant observation, archival material, media analysis, and oral history interviews, the aim of this chapter is to explain how the collective identitary narrative of the "traditional Iranian merchants" engages with systems of value that prevail within and across social fields related to the local German market, the Iranian government, and the transnational networks of Iranian merchants under changing local and 
global economic and political conditions from the 1950s until today. The shifts of value caused by the Iranian revolution in 1979 and events surrounding the political and economic crises since the mid-1990s highlight merchants' possibilities and limitations to navigate structural inequalities and contribute to their boundary-making from newcoming Iranians. As they occupy a gatekeeper position in the context of international economic sanctions on Iran, the discussion of this chapter offers reflections on relations between single values within the same system and between different systems of value. But let me first give you an idea of the setting.

\section{The Ethnographic Frame}

On a sunny day in June 2013, I take my bike to the former free port to meet Akbar, a carpet merchant, whose contact I obtained through Abtin, the Iranian owner of a high-end restaurant. Akbar is at the head of a transnational carpet merchant enterprise.

Driving to his warehouse, red brick houses on my right contrast with tall modern office buildings with neat glass façades on my left. The historical Speicherstadt, since July 2015 named UNESCO world heritage site, constitutes a uniform urban landscape of seven-story high red brick store houses and was built on 25 hectares between 1885 and 1888 (see Image 3.1). Formerly hosting the free port where merchant houses are historically located, it has been incorporated in a large-scale urban redevelopment project, the creation of a modern neighborhood named HafenCity (lit. PortCity), that runs since 2003. As I cross a newly built bridge, I take a sharp right to enter a cobbled side street. Curiously, it seems to be preserved from all the restructuration that went on around it. Each of its store houses bears Iranian or Middle Eastern names of carpet wholesale companies (see Image 3.2).

Having found Akbar's sign, I ring the bell. The man in his late thirties who opens the door presents himself as Rahim, Akbar's son. On this working day, he wears casual clothing: a blue button shirt, jeans, and sneakers. As those of most - if not all-Iranian merchants in the district, the rooms of the company, besides hosting the office, function as stock house and wholesale store at the same time. Rahim guides me to the large 


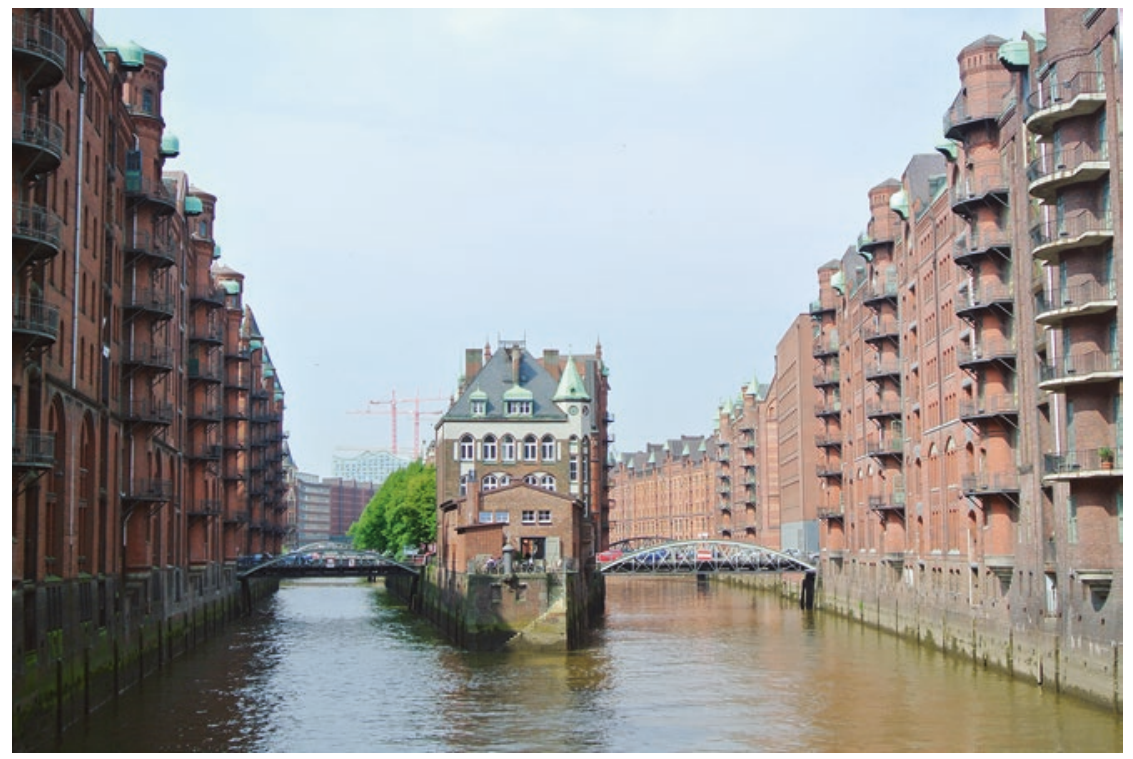

Image 3.1 View on the warehouse district (Speicherstadt) from the Poggenmühlenbrücke. (June 2013, author's photo)

showroom of more than $250 \mathrm{~m}^{2}$. Inside, piles of pile carpets, plain and elaborately decorated, sober and colorful, sorted by size and pattern, lie stacked on the floor of the old rustic stock house. The smell of wool reminds me of the small carpet shop I knew in my childhood, run by an Iranian in the town where I grew up. Rahim tells me that most of the company's customers are Europeans; Iranians usually import carpets through private travel. We sit down at a table in front of an open door looking at the canal that runs directly behind the house (Image 3.3).

While Rahim fetches black tea, I observe several men on the other side of the large room unloading rolled carpets from a lorry. A shipment has just arrived. The staff speak Persian together. Rahim comes back with a tea set identical to ones I previously saw in Iran (Image 3.4). It seems to me as if I entered a world that is distinct from Hamburg - a space which reminds me of sociabilities I have known in Iran. Before, Rahim explains, shipments were delivered through the opposite door, that is, by way of sea, but since several decades now, it is cheaper and faster to ship them by land or by air. 


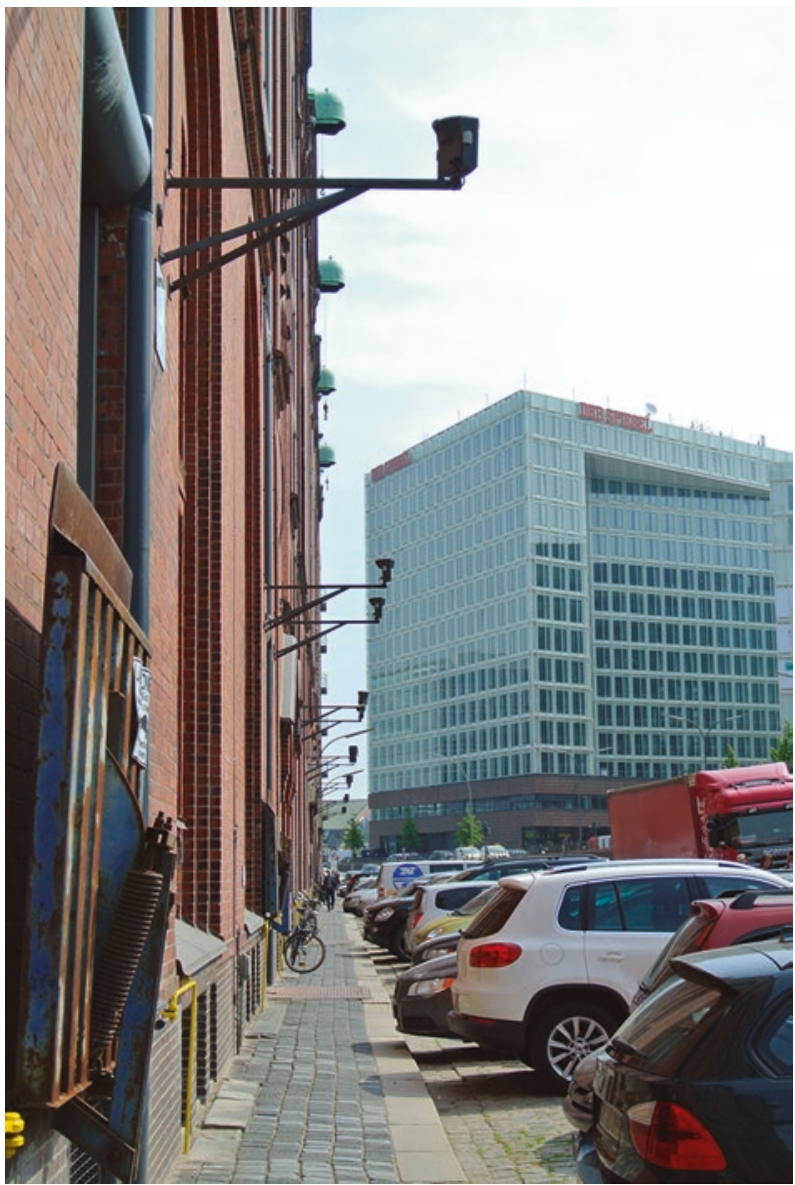

Image 3.2 Street view in front of Akbar's store. (June 2013, author's photo)

While we wait for his father, Rahim tells me that his family is from Tabriz, the capital of the province of East Azerbaijan in Northwest Iran. Later, Akbar explains me that he first came to Hamburg in the early 1950s. From then on, he collaborated with Germany-based Iranian merchants, supplying them with carpets on consignment. It was only in 1981, after the Islamic revolution, that he asked for asylum in order to bring his family to Germany and establish his own business. Rahim relates that he started to work in the PR section of the family business, 


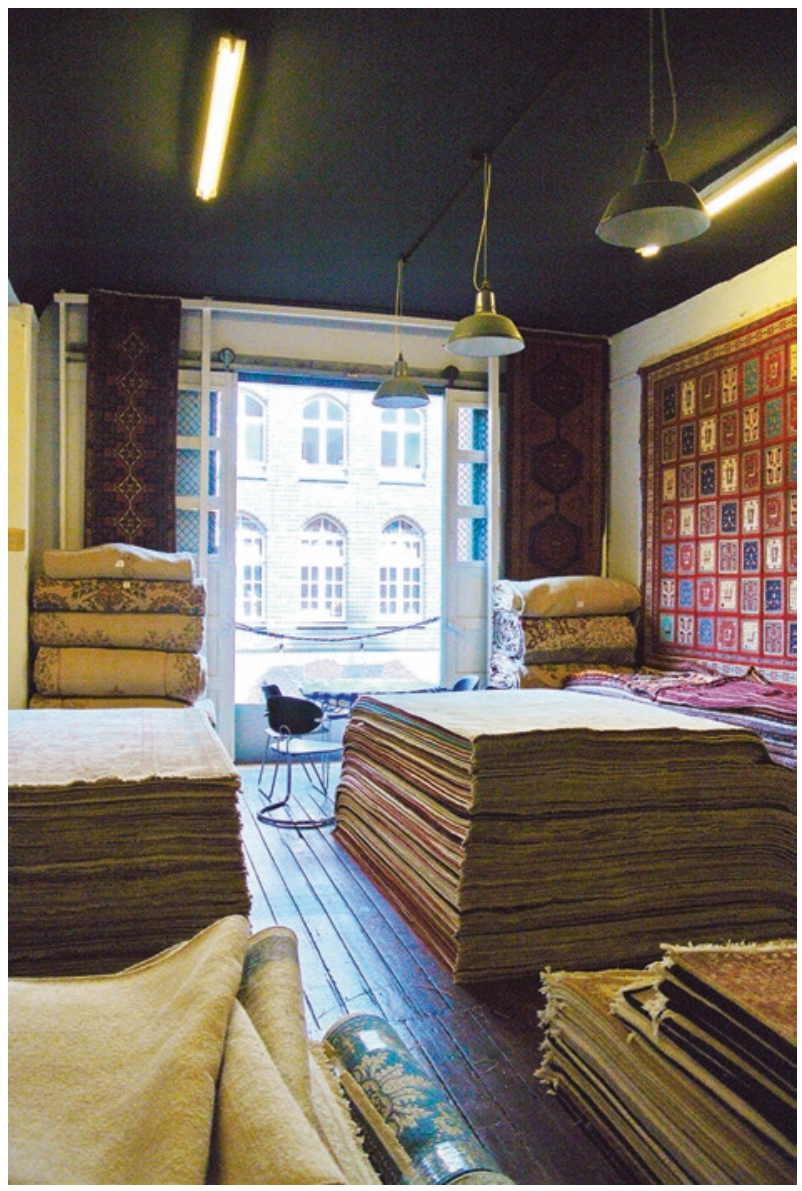

Image 3.3 Akbar's show room with view on a fleet. (June 2013, author's photo)

together with one of his sisters directly after his graduation from high school. Just like in the time of Ali and Jalal (Chap. 2), the transmission of the business within the family is still a frequent practice among Iranian merchants. Rahim and his father travel to Iran several times per year; during these trips they combine private visits and the entertainment of"multiplex and crosscutting" (Keshavarzian 2007)-transnational relations with colleagues and trade partners. Marriage still sometimes reinforces these ties: Rahim's wife grew up in Tabriz. He also tells me that 


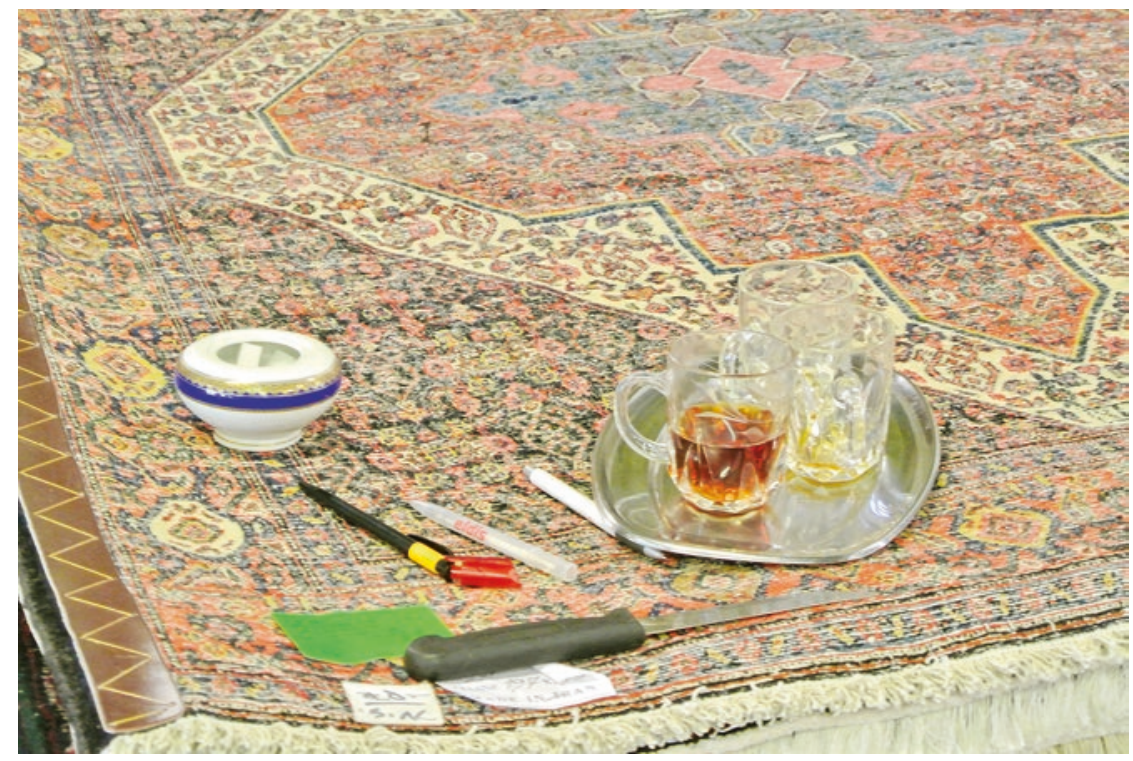

Image 3.4 Tea set from Iran on a hand-knotted Persian carpet. (June 2013, author's photo)

he is a member of the two most important Hamburg-based Iranian professional associations, AICE and BIU (Union of Iranian Entrepreneurs).

While we talk, I observe a tall man in a gray costume in his eighties giving advice in Persian in a grave voice of authority as he supervises the delivery. We stand up to greet Akbar. I start introducing myself in German, but Rahim interrupts me, asking me to switch to Persian. Akbar does not speak German fluently. As we speak in Persian, I still struggle to understand him and thus discover an accent I did not know before, that of a native Azari speaker. Another man of Akbar's age enters the show room. He also wears a costume. During my research, I witnessed several such spontaneous visits among established merchants. They also told me to pass by whenever I wanted and I found them available when I did so. Akbar talks to the visitor, apparently a long-term acquaintance, in Azari. Omid told me a few months later that Akbar nourishes strong ethnic identifications and is a skilled Azeri dancer. Indeed, due to chain migration, today many of the local Iranian merchants identify as ethnic Azeri 
(Rezaei 2009). Together, the men brainstorm names of early merchants to help me with my research. Beyond the similarities in identitary discourses, Akbar and Rahim's associational affiliation, their acquaintance with Omid and the friendly visitor indicate that they belong to a group of merchants who follow collective strategies of capital creation. Let us examine the development of these strategies through a diachronic review of the way merchants engage with changing evaluation criteria in different social fields.

\section{A Golden Age?}

Although known in Europe since the Middle Ages, Oriental carpets have become a large-scale consumer good only since the late nineteenth century (Spooner 1986, 201ff.). In these early years, the international trade and, increasingly, the production of carpets were in the hands of European businessmen who collaborated and competed with merchants in Iran (Ittig 1992; Rudner 2010, 54). With the coming to power of the monarch Reza Pahlavi in 1925, the carpet industry became part of his enhancing of Iran's national identity (Rudner 2010, 53). By the 1920s, carpets were Iran's most important non-oil export good-which it remained until today (Amuzegar 1993, 150).

As political and economic links between Nazi-Germany and Iran grew stronger in the 1930s, Germany replaced the USA as the first export market for carpets (Rudner 2010, 73). In order to gradually evict foreign companies, the Pahlavi government nationalized the industrial production in 1936. In Hamburg, however, German import restrictions secured the market dominance of German entrepreneurs and granted only small carpet quotas to those Iranian merchants who traded cotton.

Change came after World War II. Through Germany's economic upswing, the demand for luxury goods increased and trade was liberalized (Koch-Wegener 2005, 88). As early as 1950, when Hamburg was still dotted with ruins, an exhibition of Oriental carpets was organized at the Museum of Arts and Crafts (Erdmann 1950). Soon after that, Iran and the Federal Republic of Germany took up bilateral relations. Energized by the rising oil revenues, the Iranian economy thrived between 
the mid-1950s and the early 1970s (Abrahamian 2008, 123f.). At the same time, the colorful, hand-knotted Iranian carpet, the "genuine Persian” (echter Perser), became a must-have status symbol for upwardly mobile Germans (Anonym 1961, 39). Accordingly, Germany returned to being Iran's main export country for carpets, ${ }^{1}$ and Iranian imports largely dominated the domestic market. ${ }^{2}$ As a consequence, the number of Iranian migrants in Hamburg grew from about $80^{3}$ in the 1950 s to 2000 in the early 1980s (Schütt 2000, 4). A local newspaper report testifies of the expansion of the transnational business sector:

Hundreds of new carpet merchants live on the trade with "popularPersians". Shops opened in almost all big cities, on whose façades colorful neon tubes blink at night, bearing Koranic suras or Oriental names as Soraya, Mohammed and Ahmed Ali. In Hamburg, the biggest port of entry for carpets on the continent, more than 300 new carpet importers established themselves in the past few years. (Anonym 1961, 41)

During these years, Iranian migration to Hamburg was dominantly mercantile $^{4}$ (and male). Many of those who initially came for studies switched to the flourishing carpet trade. So did Parviz, the son of a bazari from Tabriz. He began to study architecture in 1951, just to become a carpet retailer in 1962. My interlocutors liked to describe the pre-revolutionary period (between 1950 and 1979) as the golden days of local Iranian economic and social life and contrast it with the contemporary situation. To understand why, we need to examine the systems of value that shaped the social fields that are relevant to their professional activity at the time.

As we saw in Chap. 2, creating capital in relations with the Iranian emperor, Shah Mohammad Reza Pahlavi, and, by extension, the social

\footnotetext{
${ }^{1}$ Imports rose from $43 \mathrm{t}$ in $1949 / 1950$ to $544 \mathrm{t}$ in $1952 / 1953$, almost doubled to $981 \mathrm{t}$ within one year and from then on steadily increased to 1709t in 1958/1959 (Adli 1960, 198).

${ }^{2}$ The market share of carpets from Iran was as high as 85\% in 1966 (Bodendiek 1966, 1) but decreased to $50 \%$ in 1978 (Classen and Voss 1978, 1), probably because their prices rose due to the strength of Iranian Rial after the oil crisis in 1973/1974.

${ }^{3}$ Parviz' estimation.

${ }^{4}$ In contrast to other German cities (Abrahamian 1982, 154), few Iranian students came to Hamburg before WWII as the city's university, established in 1919, is one of the youngest in Germany (Universität Hamburg 2014).
} 
field of Iranian foreign trade relations, was crucial for merchants' professional success. Significantly, Jalal's bankruptcy was connected to his confrontation with the Pahlavi foundation. The Western model of modernity, prosperity, and secularism together with the pre-Islamic Persian cultural heritage-those were the values Mohammad Reza Shah set forth. The Iranian emperor largely refrained from intervening in the internal social system of the Iranian bazar (Keshavarzian 2007), but he valorized the economic importance of Hamburg's Iranian merchants through two visits, in 1955 and 1967.

The way merchants participated in the program of the Shah's visits shows how they engaged with the system of value that dominated in this social field. Siavash remembers having been made to wear (uncomfortable) local seaman's clothes as he lined up with other Iranian merchants' children to greet Mohammad Reza Shah on his arrival. Parviz praised the elegant festivities at the five-star Hotel Atlantik, which still is a popular location for celebrations organized by Iranian businessmen. He remembers how he shook the Iranian emperor's hand during one of these receptions. Public media documentation of these events shows Iranian merchants next to German officials, all equally elegantly dressed in costumes and evening gowns (Norddeutscher Rundfunk 1955). For Parviz, the mastery of European ballroom dances was no obstacle, as he had learned them in Iran, before his emigration. Building on Bourdieu's theory of inequality and Graeber's concept of value (2001, 2013), I suggest that we create capital by putting forward resources that mediate values which are highly positioned in the system of value of a particular social field. In turn, it is through acts and discourses of differentiation that we disclose resources (Lambek 2013). Thus, in the social field of Iranian foreign trade, merchants boosted their capital creation by displaying resources that mediate values positioned highly in the Shah's system of value. $^{5}$

Research shows that the prevailing image of the country of origin influences migrants' chances to create capital in the country of residence

\footnotetext{
${ }^{5}$ From 1965, the situation in this social field became more complex as the growing political conflict between the Shah and clerical followers of the oppositional Ayatollah Khomeini began to manifest in Hamburg with the appointment of Ayatollah Beheshti as an Imam at the Imam Ali mosque (Van den Bos 2012).
} 
(Ong 1996; Henry 1999). In the poor, post-war Federal Republic of Germany (FRG), people were fascinated by the image of Mohammad Reza Pahlavi's wealth and orientalist splendor. His second wife, Soraya Esfandiary-Bakhtiary, whose mother was German, regularly figured in the FRG's tabloid press. So, Iranian merchants were both needed ${ }^{6}$ and admired for their financial strength and generosity in post-war Hamburg. Plus, as mentioned in the previous chapter, there was a certain fascination with the "exotic", the Oriental and more particularly "things Persian" that is deeply rooted in European, and German, history and cultural productions (Said 1978; Dabashi 2015). According to Hamid Dabashi, in the German cultural context this fascination was shaped for instance by Johann Wolfgang von Goethe's West-Eastern Divan (2010 [1827]) and Friedrich Nietzsche's Thus Spoke Zoroaster: A Book for All and None (2003 [1883-1885]). Significantly, an unreferenced newspaper comments about a basketball match in which Parviz participated from the mid1950s: "we particularly liked the Persian [Parviz], one of the HSV's [name of the team] numerous exotics". Similarly, the pensioner told me that the owner of his preferred ball house called the table he used to occupy with his friends "the table of princes" (Prinzentisch).

In sum, between the early 1950s and the late 1970s, Iranian merchants could create capital in Hamburg's society in as far as their Iran-specific resources mediated wealth and exoticism. Mayor Kurt Sieveking said in speech at the Senate's reception during the Shah's visit in 1955: "It is a special honor and a great pleasure for the Senate, the Bürgerschaft (Hamburg state parliament) and all the population of our city, to which we gladly count the members of the Persian colony in Hamburg, that the first visit of the royal couple on German soil begins in our city" (Sieveking 07/03/1955 ).

\footnotetext{
${ }^{6}$ For Hamburg, reinforcing economic ties with Iran was part of its efforts to adapt its trade relations to the Cold War context (Sywottek 1986, 427).

${ }^{7}$ Kurt Sieveking, speech of the president of the Senate of the Free and Hanseatic city of Hamburg in the honor of his majesty the emperor Mohammad Reza Shah Pahlavi and the empress queen Soraya for the dinner at the city hall on February 24, 1955, 07/03/1955, Inoffizieller Besuch von Mohammad Reza Schah und seiner Kaiserin Soraya, Empfänge und Besuche nach Einzelplan 0 (Verfassung und Verwaltung) (1947-1990.03), Senatskanzlei II, 137-1 II_4438, STAHH.
} 
It is no coincidence that the Iran-specific resources which conveyed value in German social fields are the same resources the Iranian government promotes. In his analysis of laicity in France, André Iteanu (2013) shows that values may encourage certain kinds of political hierarchies. Indeed, Western countries, in particular the USA, played a critical role in putting and keeping Mohammad Reza Shah Pahlavi in power. ${ }^{8}$ His promoting values that correspond to Western systems of value signal an effort to maintain their political support, thus perpetuating their unequal global power relations. What is striking here is that, while Bourdieu (1997) claims that classificatory schemes that shape social fields embedded in a nation-state are largely independent from each other, we find parallels between these structures in social fields that are connected to different nation-states. Thus, some systems of value shape only one social field, and others transgress the fluctuating confines of social fields and influence conditions of capital creation across national boundaries.

Yet, a very different evaluation of Iran-specific resources appears in articles on the carpet business published in two weekly Hamburg-based center-left print media—Der Spiegel, a magazine, and Die Zeit, a newspaper between 1961 and 1978. Probably motivated by the defense of the domestic carpet industry ${ }^{9}$ and German carpet importers, their critique of Middle Eastern—mainly Iranian-carpet traders exceeds business competition:

There are many possibilities of fraud; rampant oriental fantasy steadily creates new ones. There is the lamenting student from Persia at the doorstep, who needs to keep his head above water by selling the "family heirloom", of course far below the [market] price. And facing this seemingly so advantageous opportunity melts the carpet-addicted German's appropriate

\footnotetext{
${ }^{8}$ While his father, Reza Shah, promoted modernization and industrialization in Iran, he also strove to withstand forms of colonialization from the main imperial powers, the USA, Russia, and England-hence his collaboration with Nazi-Germany. In 1941, this alliance was a major reason for the allied forces to intervene, substituting him by the crown prince. In 1953, the USA intervened a second time to keep Mohammad Reza Shah in power and remove a democratic adversary, Mohammad Mossadegh (Abrahamian 1982).

${ }^{9}$ Established since the late nineteenth century, the German machine-based domestic production had profited by the importation of Iranian know-how and the inspiration from Iranian carpet designs (Helfgott 1993, 210ff.).
} 
mistrust. Or even the dark-skinned academic, maybe also the Iranian engineer temporarily working for the same company, offers a colleague a unique opportunity. (Bodendiek 1966, 3)

The article ascribes fraudulent business strategies to social (i.e. poor students), cultural (i.e. Iranian origin), and, through the insistence on the sellers' physical features, racial differences. In another article, itinerant carpet traders-former German army generals-express concern that the new Iranian competitors would downgrade what before was a "respectable business" (Kavaliers-Geschäft). If articles mention German participation in these practices, they do not condemn it with the same vehemence. Taken together, these articles draw the Orientalist image of the "carpet-crook" (Teppich-Gauner) or "Persian mat hawker" (persischer Matten-Höker), an untrained outsider to the business, who uses unfamiliar-and implicitly dishonest - methods ${ }^{10}$ to trick on the trusting customer, in order to suggest Germans to rely on serious and locally established (i.e. German) retailers or turn to domestic quality products, instead (Anonym 1961, 1971).

As the appellation "genuine Persian" suggests, genuineness, singularity, and authenticity determine a carpet's symbolic efficiency for the customer. Between the lines, the articles say that the carpet's authenticity can be measured by the merchants' honesty and accountability. Yet, these values are subordinated to the value of familiarity; mediating familiarity was a necessary condition to displaying expertise and accountability. In German society at the time, Iranian merchants were constructed as the cultural and racial Other, while what was familiar was anything identified as German or at least Western.

Thus, in German social fields in the pre-revolutionary period, the reception of Iranian merchants was ambiguous. On the one hand, resources that mediated wealth and economic growth, as well as Iranspecific resources mediating exoticism, were valorized, which allowed merchants to create enough capital to establish themselves professionally. On the other hand, their perception as exotic contradicted the value of

\footnotetext{
${ }^{10}$ One of the methods cited is, for example, granting a discount of more than the usual $3 \%$ for cash payment (Classen and Voss 1978). Indeed, in the Iranian market place to whose practices many of the traders were used, the price of a good can be influenced both in a positive and in a negative way by the personal relationship between the salesman and his customer (Keshavarzian 2007, 77).
} 
familiarity. What was exotic could not be familiar at the same time. This contradiction created a barrier to their capital creation, because resources that did not convey familiarity could not mediate honesty and authenticity.

Economic resources yes, migration-specific cultural and social resources no-Aihwa Ong (1999, 88ff.) reports that Asian transnational entrepreneurs meet similar barriers to capital creation in the USA. She makes an important contribution to Bourdieu's theory of inequality by conceptualizing limits to capital creation: migration-specific resources that cause cultural and racial Othering constitute symbolic deficits, which impede on the recognition of migrants' other resources as capital. The bringing together of Bourdieu's approach to inequality and the anthropological theory of value offers a new understanding of the effect of evaluation on capital creation. We know since Louis Dumont (2013) about the hierarchical dimension of systems of value. To him, values are not only interdependent, but they are ranked. The fulfillment of certain key values determines the mediation of others. The discussion of Dumont's work exceeds the objective of this book, but I follow Graeber $(2001,16 f f$.$) in$ retaining that relations between values are vertical, besides sometimes being horizontal. Moreover, I distance myself from Dumont's holist view and study systems of value not within societies, but within particular social fields. My historically informed ethnographic data suggests that, in the system of value that shaped the social field of the German carpet market at the time, familiarity was positioned at a higher position than exoticism or wealth. If Iranian merchants' chances of capital creation were limited, it was because while their resources exuded exoticism and wealth, they failed to convey familiarity. Accordingly, it follows that limits to capital creation arise from the inefficiency to convey a value that is of crucial significance within a particular social field.

The transnational social field of Iranian merchants was where Iranians invested most of their efforts of capital creation, as I showed in Chap. 2. While foreign business partners were invited to receptions, Siavash told me that it was with the (binational) families of other Iranian merchants that his parents spend their free time. Even institutions such as Hamburg's first Iranian restaurant, which opened in the mid-1950s, the "GermanIranian chamber of commerce" (Deutsch-Iranische Handelskammer), the "Union of Iranian Carpet importers" (Verband der iranischen 
Teppichimporteure, today called AICE), and the "German-Iranian Bank of Commerce" (today: European-Iranian Handelsbank), all founded by merchants between the 1950s and 1970s, catered to this transnational social field. In these contexts, Iran-specific resources such as fluency in Persian, religious knowledge, or close kinship, business or friendship relations with the members of highly recognized merchant families were valorized for mediating values of family cohesion, cooperation, accountability, selflessness, generosity, and piety (Keshavarzian 2007). Religious, social, and cultural rituals that mark the dense moments of Iranian merchant sociabilities play a key role in renewing their collective system of value over the decades (cf. Robbins 2015).

The dynamics around the construction of the Imam Ali mosque illustrate how merchants collectively engaged with chances and limits to capital creation in these three social fields. In 1951, a group of pious and successful merchants, including Ali founded an association ${ }^{11}$ and entered into negotiations with the Senate, that is, Hamburg's federal state government, in order to gain support for the mosque's construction. However, archival documentation shows that the Senate skirted the Iranians' request for infrastructural and financial support. In the end, the merchants financed the construction of the main building with their own resources - thus demonstrating generosity, selflessness, and pietythrough donations from peers in Iran and with the transnational support of Ayatollah Boroujerdi, one of the most important Shia clerics in Iran at the time. ${ }^{12}$ In Boroujerdi, they chose an ally which would not endanger their relations with the Shah, who visited the construction site in $1967 .{ }^{13}$ You can see the Senate's restraint reflected in then-Senator Sieveking's bodily posture at the foundation stone ceremony in 1960 (Image 3.5).

\footnotetext{
${ }^{11}$ The "Association of the promoters of an Iranian-Islamic mosque in Hamburg" (Verein der Förderer einer iranisch-islamischen Moschee in Hamburg).

${ }^{12}$ Senatskanzlei, memorandum (Vermerk), 20/07/1951; Verein der Förderer einer iranischislamischen Moschee in Hamburg e.V., invitation to the setting of the foundation stone, February 1960, both Senatskanzlei II, Sonstige Glaubensbewegungen (1922-1988), 131-1 II _874, STAHH.

${ }^{13}$ Rumpf, Senatskanzlei, memorandum (Vermerk), 19/05/1967, Empfang anlässlich des Besuches des Schahs von Persien, Mohammad Reza Pahlavi und seiner Gattin Farah am 03. und 4.06.1967, Empfänge und Besuche nach Einzelplan 0 (Verfassung und Verwaltung) (1947-1990.03), Senatskanzlei II, 131-1II_4405, STAHH.
} 


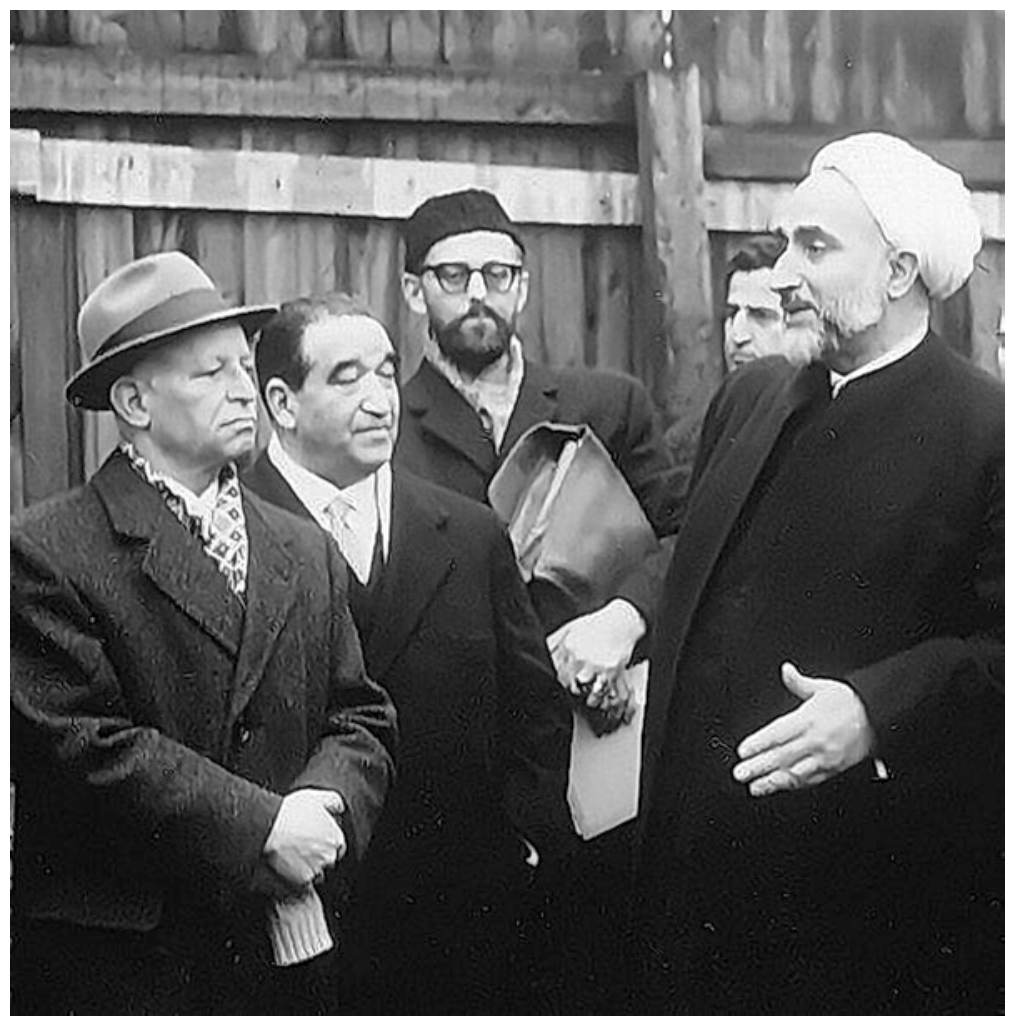

Image 3.5 Foundation stone ceremony of the Imam Ali mosque in February 1960. Hamburg's Senator Kurt Sieveking on the left, and Imam Hojatolleslam Mohammad Mohaghaghi on the right (Siavash's family archives)

Thus, as merchants met with barriers to their capital creation in German contexts, they invested further effort in generating capital in transnational social fields.

In sum, the bundling of individual interests within the transnational field of Iranian carpet merchants worked as a collective strategy to confront the barriers to capital creation caused by their difficulty to mediate familiarity in German social fields. In concurrence with extent literature in migration studies (Light et al. 1994; Bauder 2005), research of Iranian ethnic entrepreneurship in different Western countries points to the support this occupational form can play in countering discrimination and 


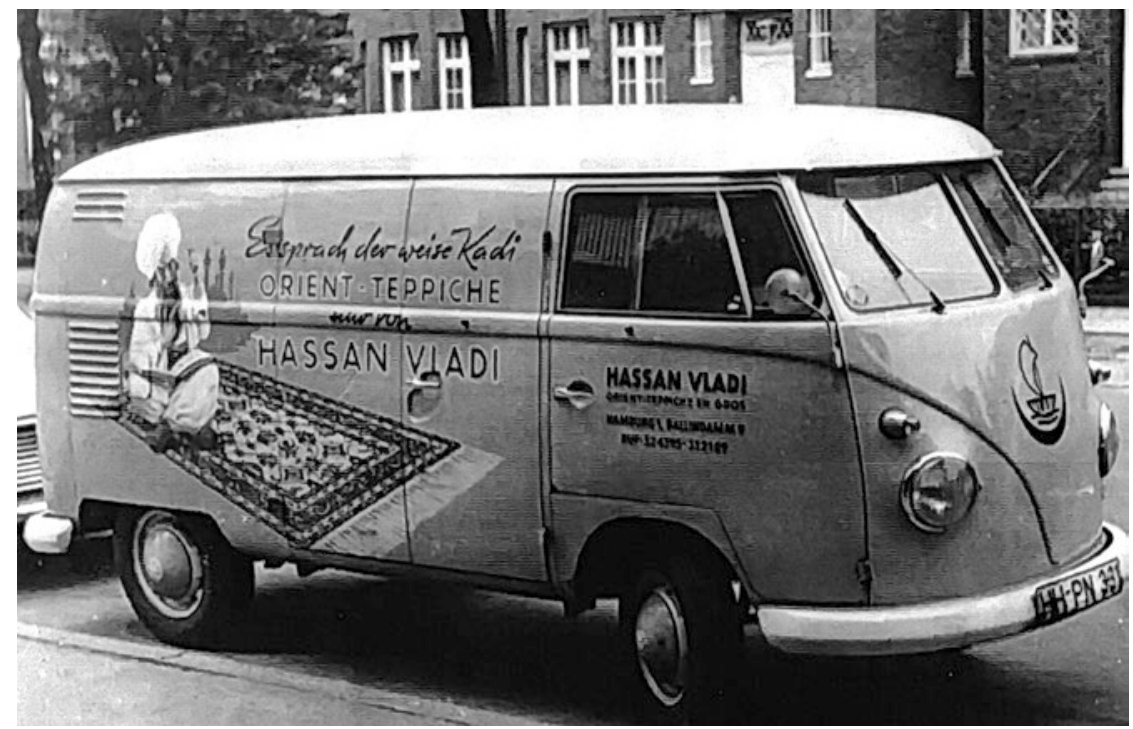

Image 3.6 Utility vehicle of the merchant business Hassan Vladi, probably the 1950s (Parviz' family archives)

downward social mobility (Khosravi 1999; Moallem 2000). The merchants' collective agency was sustained by their relatively small numbers, a common bazari background in Iran, and their participation in a system of reputation in which mutual trust and control relied on multiplex ${ }^{14}$ and crosscutting relations.

Iranian merchants' engagement in their own transnational social field, but also their participation in the field of Iranian foreign trade, in turn, influenced the way they interacted in German social fields. They did not try to generate new Germany-specific resources to conform to the dominant values of familiarity, reliability, and honesty. Instead, they put forward certain Iran-specific resources with the aim of increasing the value of exoticism. Within the non-standardized carpet commerce, they did what Boltanski and Chiapello (2005) call codifying: they advertised certain commercial and personal practices and objects as Iran-specific in

\footnotetext{
${ }^{14}$ In Hamburg, the multiplexity of merchants' social ties relied on shared leisure activities and neighborly ties. Siavash told me that most merchants lived and worked in the same districts.
} 
order to sustain the goods' authenticity. You can see this, for instance, in a publicity bearing a bearded turban wearer who sits on a flying carpet (Image 3.6). In doing so, they began to market ethnicity, or rather, as merchants were of diverse ethnic backgrounds, an Orientalistic image of Iranian national identity. This attitude of reshaping the value of their Iran-specific resources can be described as what David Graeber (2001, 88f.) defines as "politics of value": people construct meaning that both acknowledges and resists, that is, intends to act upon, existing systems of value.

Given the barriers to capital creation they met among Germans, why do my interlocutors see this period of time as particularly positive? As part of the narrative of the "traditional Iranian merchants", the discourse of the "golden age" of thriving Iranian social life and the muting of experiences of discrimination were constructed retrospectively. They are an expression of merchants' contemporary politics of value, to which two mayor historic developments largely contributed, as the next two sections will show.

\section{The Iranian Government, the Flüchtling, and Illicit Business Practices}

Systems of value may shift over time, but there are events that bring about more sudden and dramatical transformation. The Islamic Revolution in Iran in 1979 was one such event. Parviz' boundary-making toward newcoming Iranian migrants indicates key issues caused by its impact on the three social fields relevant for Iranian merchants:

Sonja "How was it actually like when in 1979 the revolution happened? Many new Iranians came here. How was that for those who had been here for a longer time, like you?"

Parviz "Yes, many refugees [Flüchtlinge] came. They smuggled and... and other things, teriak [opium, in Persian in the original] and weapons and all. And until then were... Persians have had a good name, but after not anymore [sic!]."

Sonja "This changed then, but was that maybe also because of the new government in Iran?" 
Parviz "Yes." [he takes a sip of liqueur, a few seconds of silence] Sonja "And then, new carpet traders came, too."

Parviz "And came, and again, they didn't make it, [and went] back [sic!]."

(Interview, April 2014)

To understand the value shifts, let us keep in mind three issues: the Iranian government (Parviz' silence is significant), refugees, and illicit business practices.

First, with the overthrow of the monarchy, the system of value that shaped the social field of Iranian foreign trade underwent drastic changes. Constructed in opposition to the Western-oriented monarchy, the new regime glorified modesty, religious piety, altruism, regime-loyalty, and family cohesion, while it rejected any idea or practice associated with the West, including conspicuous consumption and self-interest, as alienation and gharbzâdehgi (Weststruckness) (Khosravi 2008). It valorized the bazar and individual bazaris gained high positions in the government, namely those who had been important allies in the revolution. However, it sanctioned merchants who could not prove their adherence to the regime's values, for instance through expropriation (Abrahamian 2008, 179; Keshavarzian 2009). Sepehr, Ali's son, lost his businesses in Iran and fled to Germany for this reason. According to Oliya, Omid's sister (one of the very few women I met who work in Iranian merchant businesses), it was not until Mohammad Khatami's presidency (1997-2005) that relations between Hamburg's Iranian merchants and the Iranian government stabilized.

The new Iranian government began to intervene in the bazar and new, overlapping hierarchical structures co-opted the old system of reputation (Keshavarzian 2007, 107; Sadjed 2012, 120-24). Religious foundations (bonyâd) became major economic players. They opened branches in Hamburg in the mid-1980s, offering a greater variety and more economic carpets than established merchants, thanks to their operating outside the bazar economy (Rezaei 2009, 92f.). Due to the government's political ideology and the war with Iraq (1980-1988), restrictive and unstable foreign trade policies fostered corruption and smuggling (Digard et al. 2007, 250; Erami and Keshavarzian 2015). Consequently, merchants had to redefine their strategies of capital creation, but how they 
did this is not something people liked to talk about, as we can see in Parviz' silence.

The following example shows one way of engaging with the Iranian government's system of value in the field of foreign trade. In a 2012 documentary, internationally broadcasted on the Iranian public TV channel "Jam-e jam", the 78-year-old carpet retailer and former merchant Farhadian stresses that his aim is not primarily to make profit, but to raise the customers' interest in Iranian carpets. On this, the interviewer says:

"The real labor is with the weavers..."

Farhadian "I would really like to kiss the hands of all these artistic weavers from afar, and I just would like to tell them that it is only for you that I built this [carpet shop], to represent the outcome of your work at its proper value."

Journalist "Exactly, this is your service to our culture, your service to our traditions, to our efforts, to our values. It represents the effort and work needed to bring an Iranian carpet, a handwoven rug, to a sales exhibition in the heart of Europe. Anyways, this is a demonstration of your attention to genuine Iranian culture." (Translation by the author (OPT1001 2012))

The man further states that his only daughter married an Iranian (i.e. not a German), while his sons are going to take over the family business in Hamburg, indirectly stressing that he had not become "weststruck" even though he lived in Germany since many decades (OPT1001 2012). Thus, the Iranian government hails the merchants' staging of the moral, that is, socially responsible, businessman ${ }^{15}$ (Amuzegar 1993, 20ff.; Keshavarzian 2007, 54) and presents in him the portrait of the ideal migrant, who promotes the values it seeks to set forth. This image is reminiscent of China's discourse on its overseas citizens (Ong 1999, 43).

If merchants put forward certain values in a particular social field, it does not necessarily imply that they personally adhere to them. Siavash termed this flexibility of mediating different values in different social fields the "bazari mindset" (see Chap. 2). It can also be thought of as diplomacy (Marsden 2018) and complaisant submission in sociability

\footnotetext{
${ }^{15}$ Also named javânmard (Adelkhah 1999, 30-52).
} 
(mosâmehat). All in all, it is a form of impression management (Goffman 1990). While it is particularly crucial in transnational entrepreneurship, and for migrants in general, as we shall see in the following chapters, this practice can be observed in many social contexts. As Graeber $(2013,231)$ argues, the distance between strategical politics of value and personal convictions is

what makes it so easy, in contexts characterized by complex and overlapping arenas of values, for so many actors to simply stroll back and forth between one universe and another without feeling any profound sense of contradiction or even unease.

Second, the revolution in Iran, the arrival of new migrants, and changes in the public perception of immigration influenced the values which Iran-specific resources mediated in German social fields. The hostage crisis at Tehran's US embassy (1979-1981), the Iranian supreme guide Ayatollah Khomeini issuing a fatwa against Salman Rushdie (1989), and local repercussions of these international events, such as Iranian political murders on German territory: fascination with Iran's Orientalist allure was replaced with estrangement and suspicion of its authoritarian, Islamic regime and openly anti-Western discourses (Hesse-Lehmann and Spellman 2004; Van den Bos 2012; Adelkhah 2016). While Germany remained Iran's most important economic partner in the West (Bösch 2015 , 348), it abolished the visa-free entry for Iranians. Thus, most newcomers passed through the asylum procedure-and there were many. Within a decade, Hamburg's Iranian population quintuplicated to reach about 10,000 in 1990 (Helfer 1989).

Polemics around the notion of "asylum-abusers" (Asylbetrüger), who would take advantage of the social system, stirred resentments in the German society (Heinrich Lummer in Göktürk et al. 2007, 113f.). Parallelly, the exclusion of the cultural and racial Other became more pronounced. Significantly, when chancellor Helmut Kohl took up his duties in 1982, he declared wanting to send back half of Germany's Turkish immigrants because, in contrast to Italian, Portuguese, or South Asian migrants, they would not adapt to the German society (tkr/DPA/ DPA 2013). Through these dynamics, Iran-specific resources largely lost 
the value of exoticism; their new estrangement to Germans threaded to reinforce already existing barriers to merchants' capital creation in Germany.

It is thus significant that, when we talked about Abtin, a successful restaurateur, Akbar qualified him as a Flüchtling ("refugee", he said it in German!). By his tone, I could tell that he did not hold much regard for people he characterized as such. In contrast, he showed respect to the living and deceased members of early merchant families he had known. Just like Parviz and many other merchants, Akbar seeks to distance himself from newer migrants and mark his identification with early merchants, even more so because he himself passed through the asylum procedure. That different "vintages" of migrants may look at each other with suspicion is an important paradigm in migration studies (Kunz 1973; see also Lamphere 1992; Vertovec 2015). Research on Iranian migration in various destinations shows that the time of departure is a frequently used marker in internal boundary-making (Kamalkhani 1988; Kelley et al. 1993; McAuliffe 2008). This internal boundary-making is related to the fear of what Boris Nieswand $(2011,80 \mathrm{ff}$.) calls "collective devaluation". We can see it in Parviz' reference to the "name" of Iranians in German society, which he claimed was good until the revolution. Merchants were afraid that their Iran-specific resources lose the value of exoticism.

Thus, within the increasing diversification of Iranian migrants after the revolution, merchants stuck to their original politics of value as they kept displaying those Iran-specific resources which convey exoticism. These politics were sustained by the fact that, by the 1980s, the value of authenticity, originally put forward as a critique of capitalism, has become crucial in determining consumer practices (Boltanski and Chiapello 2005). According to Marylin Halter $(2007,17)$,

the more artificiality, anonymity, and uncertainty apparent in a postmodern world, the more driven are the quests for authentic experiences and the more people long to feel connected to localized traditions seeking out the timeless and true.

Indeed, a similar orientation toward authenticity and the marketing of ethnicity can be observed in many areas, such as art, tourism, and food 
(Comaroff and Comaroff 2009; Cravatte 2009; Grasseni 2005). We saw that authenticity was already an important value in the German carpet market before. However, its mediation was tied to the mediation of familiarity. What had changed was that Iran-coded commercial and personal practices and objects increasingly mediated authenticity. In other words, the same Iran-specific resources that accounted for Iranian merchants to be considered unfamiliar and untrustworthy in the 1960s came to mediate values that were efficient at generating capital by the 1990s. Simultaneously, merchants set forth their long-term presence in Hamburg in their collective narrative, because this resource began to mediate familiarity, reliability, and accountability. Significantly, a documentary movie from 1989 attributes the persistence of the warehouse district to the ongoing economic activity of Iranian carpet merchants and underlines not only their Iranian ways of doing but also their local rootedness and their keeping alive local merchant tradition (Helfer 1989). Interestingly, the otherwise very different system of value in the field of Iranian foreign trade intersects in the valorization of authenticity through its hailing of modesty and craftmanship. Hence, merchants' politics of value within the social field of the German carpet market contributed to modifying the dominant system of value.

Finally, Parviz describes newcomers' business strategies as illegal and amoral, hinting to the fact that new immigrants' resources did not mediate the values relevant in the transnational field of Iranian merchants. There were two types of newcomers. First, there were Muslim Iranians who, according to Omid, were embedded in the bazar's system of reputation and acquired the companies who were sold because of supply difficulties or because their owners were Jewish Iranians who quit their business in the aftermath of the Islamic revolution. Conforming to the values of this social field, they could generate capital and were quickly integrated (Rezaei 2009, 89).

The second type of newcomers who turned themselves into merchants and retailers lacked of social relations in bazar networks. Behruz father (Chap. 5), for example, had been a lawyer in Iran. As his diploma was not recognized in Germany, he established himself as a carpet merchant. In contrast to the family businesses of established merchants, most of these self-made merchants or retailers built on short-term cooperation and 
small networks with acquaintances and friends. In doing so, they skirted the system of reputation, because they could not mediate crucial values, or simply because they privileged capital creation in other social fields. Importantly, these refugees identified, like merchants, with the urban middle class. Their mutual boundary-making was thus less tied to class identities than to a mismatch in the values the newcomers and the longstanding Iranian merchants applied to their work.

Consequently, established merchants were hardly able to control newcomer's business strategies (see also Keshavarzian 2007, 152f.), if it was not through boundary-making and by strengthening their adherence to their own system of value. Instead of the German colleagues in the 1950s and 1960s, it was now the established Iranian merchants who blamed their bazar-outsider compatriots for unfair competition. A German documentary from 1989 shows M. Azadi-presented as an intellectual and a well-established merchant of antique Persian carpets - in front of a carpet discount shop, accusing its dumping prices of endangering reputable businesses (Helfer 1989). Pnina Werbner (1990, 66ff.), observes similar distinction of established migrant entrepreneurs from newer competitors through the discursive construction of moral and social superiority among traders of Pakistani origin in Manchester. Established merchants' internal boundary-making thus served not only to protect their own system of value, but also to sustain their collective strategies of capital creation in Germany and in relations with the Iranian government.

Strikingly, the discussion shows that the system of value in the transnational social field of Iranian merchants remained relatively stable despite important political and economic changes. This stability may both be the reason and the outcome of its own resourcefulness: merchants drew on Iran-specific resources they had created in this social field to convey values, such as piety and selflessness, that had become relevant in the social field of Iranian foreign trade. Iran-specific resources also served to uphold and strengthen their effort to increase the value of exoticism and authenticity in the German context.

While hegemonic systems of value may indeed change quickly and dramatically, for instance through sudden political events, everyday politics of value of less powerful agents across local and transnational social fields may also influence value systems over extended time spans. Thus, 
modifications in systems of value rarely happen through exclusively hierarchical processes. Agents' power derives from their-inherently unequal_-potential for action (Graeber 2001, 259ff.). Value systems are thus produced by the interaction of agents pursuing malleable strategies of capital creation from unequal power positions.

\section{Collectively Narrating Through the Crisis}

Trade with Iranian carpets in Hamburg reached its height in the mid1990s. Then, however, it experienced drastic market breaks. The crisis grew even more acute in the 2000s, as one can see in the graph (Fig. 3.1). Between 1992 and 2013, the number of Iranian carpet merchants dropped by $88 \%$. This section will show how the Iranian merchants' collective identitary narrative in its contemporary form puts forward the same resources to convey diverging values in each of the three relevant social fields and in doing so engages with shifts in systems of value caused by political and economic changes.

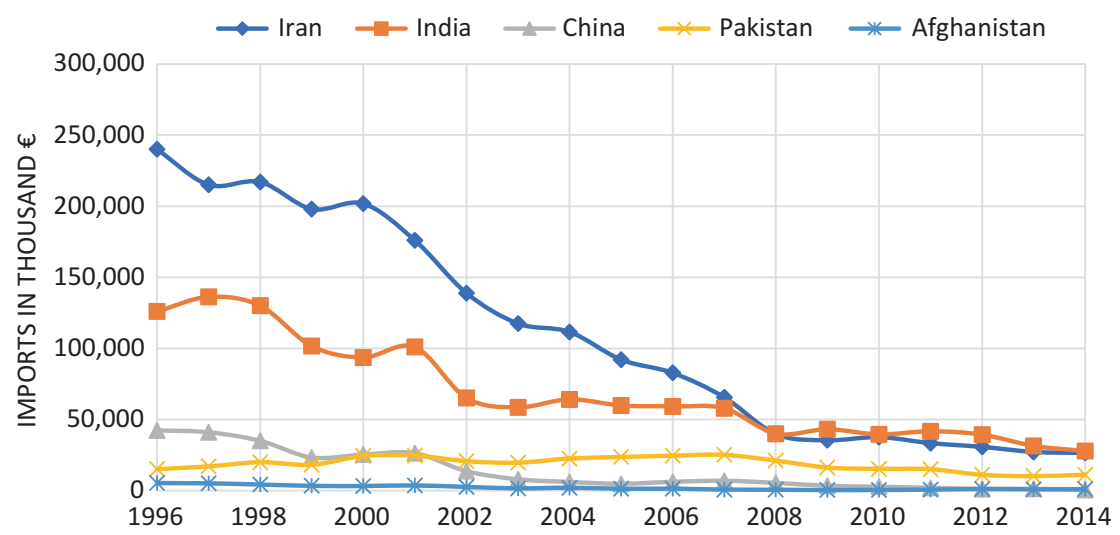

Fig. 3.1 German import of hand-knotted carpets from selected countries between 1996 and 2014 (in thousand Euro, product codes: WA57011010, /90, /91, 193, 199, and WA57019010, 190). (data: Statistisches Bundesamt 2015, graphic by the author) 
From the mid-1990s onward, the original values of the Iranian revolution that shaped the social field of Iranian foreign trade were complemented by values that responded to economic, political, and social changes. Iran's classification as a member of the axis-of-evil in 2002, President Mahmoud Ahmadinejad's (2005-2013) fierce anti-Zionist discourses and the conflict over the Iranian nuclear program (Abrahamian 2008, 183ff.), finally the conclusion of the "Iran Deal" (Joint Comprehensive Plan of Action) in 2015, then the USA's withdrawal under the Trump administration in 2018: the Iranian economy is marked by recession and uncertainty. As economic and political pressures grow, trade relations with Europe and, in particular, with Germany become even more important - and carpets still are one of Iran's largest non-oil export products (Statistical Centre of Iran 2014, 438). Private import-export enterprises, indeed, are crucial agents in circumventing trade restrictions and embargos (Gerhardt and Senyurt 2013). Significantly, in an interview from 2007, the Iranian deputy foreign minister for economic affairs at the time, Ali-Reza Sheikh-Attar, explains that one of the reasons for the "close understanding and direct contact between Iran and Germany in the economic field" is the "large Iranian community living in Germany" (Interview with the Iranian Deputy Foreign Minister for Economic Affairs Ali-Reza Sheikh-Attar 2007).

Today, the Iranian government continues to promote the revolutionary values of modesty, chastity, and piety. Simultaneously, its ever more neoliberal market economy, rising levels of education, the nuclearization of the family, and opaque, overlapping, and irregular economic structures (Keshavarzian 2007; Erami and Keshavarzian 2015), grant increasing value to wealth, autonomy, and professionalism (Kian-Thiébaut 2005; Sadjed 2012). Depending on the situation, resources that mediate familiarity with the German context may underline professionalism as they may be interpreted as a failure to convey regime-loyalty. The Iranian regime collaborates on a regular basis with Hamburg's merchants, mainly through the association $\operatorname{AICE}^{16}$ (Rezaei 2009, 91), and through frequent visits of officials in Hamburg. In response to the introduction of new

\footnotetext{
${ }^{16}$ Most merchants involved in the system of reputation are members of AICE, BIU, and/or the Iranian-German European Carpet-Importers Association (EUCA).
} 
values, the government also created alliances outside of the merchant networks. Javid, a 69-year-old corporate consultant who immigrated to Germany as a young adult in the early 1980s, told me that it was the then-General Consul who proposed him to co-found the "Union of Iranian Entrepreneurs" (Bund Iranischer Unternehmer, shortly BIU) in 2007. The aim was to create an intermediary who could facilitate collaborations between the Iranian government and the Hamburg Senate.

Iran-related political events, but also the global economic crisis as well as local political and infrastructural changes complexified the system of value that dominates the social field of the German carpet market to a point that a resource may simultaneously mediate value and dramatically fail to do so.

Iran's marginalization from the global political and economic exchanges impacts on the trade infrastructure, ${ }^{17}$ but, more importantly, on the meaning of Iran-specific resources. Plus, by the early 2000s, the German politics of immigration shifted from differentialism toward assimilation, which represents the requirement for migrants to mediate familiarity through cultural closeness (Aumüller 2009). We can see the effects of these developments in the following example: in 2010, the BIU created, together with the Iranian government and the Christian democratic Senate, the so-called Iran House Project (Iran-Haus Projekt). Javid, its president, told me that the aim was to show a "positive image" of Iran and foster business relations. However, the local population protested against the cooperation with Ahmadinejad's government (Smechowski 2010), condemning the Iranian government for anti-Semitism and human rights violations. ${ }^{18}$ The oppositional SPD (Social Democratic Party of Germany) joined the movement (Dobusch 2010), which, according to Javid, accounts for the failure of the project-alongside inconstancies in the Iranian state financial support. The values of democracy, equality, and

\footnotetext{
${ }^{17}$ Akbar, for instance, saw his dollar accounts confiscated and therefore lost clients in North America. Plus, the trade infrastructure is restricted, as Iranian banks in Hamburg work under sanctions or closed down.

${ }^{18}$ Among the most important critics of this project was the group "Stop-the-bomb", mainly constituted by Zionists and pro-Israel activists ("Original and Prominent Supporters" 2015). For the complex connections between Anti-anti-Semitism and the discrimination of Muslims in Germany, see Younes (2015).
} 
human rights are not always relevant in the carpet trade. Here, familiarity does not have to pass through cultural and racial closeness but can be created through long-term relations. Yet, these values are crucial in the social field of Hamburg's domestic politics, as they are essential to European and Western political identity (Guilhot 2005; de Jong 2017). The fact that merchants' mediation of exoticism and familiarity - central values in the social field of the German carpet market-was conditional to the compliance with democracy, equality, and human rights indicates that, in this example, two social fields overlap. Their systems of value are different, but unequally powerful. Thus, failing to convey democracy, equality, and human rights threatens to compromise Iranian merchants' capital creation as it increases their difficulties to mediate both exoticism and familiarity.

The international economic crisis of the late 2000s also influenced the system of value in the German carpet market. Parviz and Rahim asserted that the taste of Northern Europeans and Americans shifted toward sober colors and plain designs, which they find in more economic Indian produces (see also Piehler 2009). Their comment suggests that instead of wealth, mediated through expensive and colorful Iranian carpets, customers value simplicity, plainness, and frugality.

The new obstacles for Iranians to convey exoticism and familiarity and the shift toward simplicity calls for other competencies, Javid explains. In concurrence with the new values in the social field of Iranian foreign trade, professionalization would help smoothing the inefficiency of Iranspecific resources to create capital:

It is not as if because of crisis less carpets are sold, and that all of a sudden people don't want to have Persian carpets anymore. Instead, is [sic!] because of the crisis we heard much more negative things about Iran, than about the positive carpet. Until now, all people... How to say? Analphabets, came from Iran, had some money, about 100,000€. Then, they borrowed another $500,400[, 000 €]$ from an Iranian, brought carpets in, imported them, and sold them. You did not need any expertise for this, nor did you need to do anything. But these times are over! (Interview, June 2014) 
He thus suggests, in a depreciative tone that stresses his own educational and professional resources, that a participation in the merchants' system of reputation no longer guarantees business efficiency. Merchants indeed adapted their business strategies in various ways: Akbar and Rahim included cheaper Indian, Chinese, Pakistani, or Afghan carpets into their range of products and invested in new markets, like the Saudi Arabian market. Omid, who holds a Master in Business Administration, instead, sets forward a focus on Persian quality imports and antique carpets. They told me that other colleagues downsized their stocks, shifted to online sales, moved their premises to cheaper locations close to the airport, or switched to the retail or interior equipment business. Some moved on to the USA or elsewhere, or returned to Iran.

The marketing of Iranian culture is a way for Omid to mediate the failure to convey the values of democracy, equality, and human rights. "This is also why I say 'Persian' [i.e. instead of Iranian] carpets," he told me. "What is identity good for if I can't even pay the rent for my store?" (field notes, October 2013). Following a similar rationale, several press portraits of merchants characterize them as "politically impartial" (Spillmann 2003; Hertel 2011; Fründt 2014). Correspondingly, Omid's large show room is decorated with Iranian cultural artifacts: a dummy with a colorful, embroidered vest and a huge book on a holder, probably by the poet Hafiz. When I first visited him, he told me that he awaited a group of people belonging to a German private club of which he is a member for an Iranian dinner. While staging cultural Iranianness is a popular way for people to redefine the values Iran-specific resources mediate (Sanadjian 2000; Mobasher 2006; Gholami 2015), in the case of carpet merchants, they have to fine-tune their politics of value so as to not impede on their capital creation in the social field of Iranian foreign trade.

I argued above that Iran-specific resources increasingly fail to create capital due to Iran's image in the international political landscape. Yet, merchants have been coding Iran-specific resources to convey authenticity through exoticism since pre-revolutionary times, and from the 1980s, their efforts have shown positive results, sustained by the rising interest in authenticity in the larger society. In addition, through their long-term presence, they began to mediate familiarity despite cultural difference. 
The nostalgia of the "golden days" in which the image of Iran still reflected the attraction of the Oriental, yet, Western-orientated, wealthy and secular monarchy, through a selective "reordering of the past" (Guillaume 1990), is part of the merchants' politics of redefining the value of Iranspecific resources.

Since the early 2000s, local infrastructural changes second the Iranian merchants' capital creation. Granted, the integration of Hamburg's free port into the aforementioned, newly created, hybrid HafenCity entails rising rents and new administrative procedures. However, in its course, the local press came to valorize Iranian carpet merchant houses as last upholders of the historical ways of doing trade in the neighborhood:

Coffee, tea, and carpets - these are the "elements" which had marked the Speicherstadt for decades. One can still find the coffee sector, even though one must take a close look. The tea sector no longer marks the landscape behind the red brick houses, either. The carpet, however, survived visibly with its small-scale structures and great variety [...]. The restructuration process is ongoing, the stocks dwindle. Will this wonderful piece of Orient remain with the Hanseatic city? (Hertel 2011)

Indeed, the restructuration managers declare wanting to preserve the carpet stock houses, which became a tourist attraction (Wolf 2005; Schmidt 2013). The nostalgia one can sense in this discourse is often combined with a romanticization of the carpet business, stressing the cultural alterity—the exoticism — and the historical continuity — the familiarity—of the merchants' practices:

The lorry that rolls through Hamburg's Speicherstadt on this winter morning drove for eight days and took several thousand kilometers. Now it stops in front of a red clinkered stock house. A scuttle opens in the first floor. Warehousemen descend the rope on a simple winch and start heaving the precious cargo piece by piece to where it is warm and dry: 1650 handknotted carpets just arrived from Tehran. A scene from times long past. (Fründt 2014)

Not only in discourse but also in practice, the long-term presence of Iranian merchants strengthens their mediation of familiarity. In a recent 
documentary (Schanzen and Keunecke 2018), the head of one of the oldest Iranian carpet merchant enterprises and the German manager of a transportation business state that ongoing collaboration over generations, which is facilitated through their neighborhood relations in the warehouse district, also helps to confront the defamiliarization of Iran-specific resources and the shift of values in the context of the economic crisis.

Thus, in the social field of the German carpet market, merchants create capital (and circumvent the failure to mediate democracy, equality, and human rights), on the one hand, through Iran-specific resources that refer to apparently apolitical commercial and personal practices and objects stressing family cohesion and tradition, as well as Germanyspecific resources that reify Hamburg merchants' historical ways of doing, convey authenticity and exoticism. On the other hand, Germany-specific resources that refer to their long local presence and business history mediate familiarity, expertise, and accountability. Strikingly, in this context, exoticism and familiarity are no longer mutually exclusive values, as they were during the pre-revolutionary years. However, the merchants' capital creation remains particularly precarious as their politics contest dominant systems of value and the interpretation of their resources may hence be reversed at any time.

Finally, in the transnational social field of Iranian carpet merchants, the drive toward authenticity in German social fields, and the instauration of trade barriers in the Iranian context reinforced the existing system of value, as it strengthened the comparative advantages of those who were embedded in the merchants' system of reputation. As Parviz mentioned in the conversation cited at the beginning of the previous section, the number of bankruptcies among wholesalers operating outside of longterm trust relations largely exceeded those among its members. This was because trade networks based on long-term relations built on mutual credit are highly interdependent: the insolvency of one member may affect the viability of other firms (Werbner 1990, 59-66). Moreover, family enterprises offer a workforce that more readily accepts flexible working conditions and salaries (Werbner 1990, 58f.; Jacques-Jouvenot and Droz 2015). In order to sustain collective business efficiency, merchants within the system of reputation have more flexible terms of payment, that is, credit, delayed payment or other forms of generalized 
exchange (Sahlins 1972, 196ff.), and better value for money. Outsiders to the network, instead, have to comply with the conditions of balanced exchange, that is, no delays or only short delays allowed for settling accounts, as they are considered untrustworthy (Keshavarzian 2007, 151f.). Significantly, a TV documentation from 2008 shows Omid as he buys a precious carpet at the Tehran bazar. He kisses the wholesaler on the cheek when the price is settled as a symbol of respect and long acquaintance. A German retailer asks the wholesaler how much the carpet would have costed if he had bought it instead. The merchant names a price exceeding by $€ 1000$ what Omid paid. The latter, in turn, comments: "He knows me for forty years. He knows you for forty minutes. That's the problem" (Demurray 2008).

Yet, here too, the drive toward the segmentation of the postrevolutionary bazar and the professionalization of merchants outside of the traditional social networks introduced new values, which are apparent through the role of BIU and Javid in boundary work. I witnessed Omid and one of his merchant friends value Javid's connections to German politicians, but also scoff his friendship with the Imam Ali mosque's imam. His sister Oliya, a trained biologist in her mid-sixties with hair dyed in blond who speaks Persian and German to her two white terriers, volunteered as a treasurer at BIU for five years. She critiqued its high membership fees and low political impact, and Omid predicted that BIU is going to lose its influence. Yet, I could tell that my interlocutors withheld the whole extent of their accusations, which suggests that their system of reputation, in which inner conflicts are resolved out of sight from the public (Keshavarzian 2007), had come to include BIU and its members.

The valorization of internal social coherence and cooperation among merchants largely accounts for the success of their collective strategies of capital creation. I witnessed merchants visiting each other, or listened to them telling me they saw such and such at a wedding lately. Several interlocutors told me that the mosque for many remained an important setting for sociability. Merchants defer diverging identifications, religious beliefs, and moral and political convictions ${ }^{19}$ and maintain multiplex and

\footnotetext{
${ }^{19}$ For example, as mentioned above, Omid entertains long-term business relations with German retailers, and is member of a local private club.
} 
crosscutting social relations, often over several decades and generations. Their reduced number further contributes to a greater cohesion and control (see also Erami and Keshavarzian 2015, 126). The high level of integration within this social field explains why it has not been necessary for Akbar to speak German fluently.

To resume, the Iranian carpet merchants' collective identitary narrative promoting the resources such as Iranian identification, family cohesion, a long history in Hamburg, and (sometimes) also religious adherence caters to systems of value in three social fields. Strikingly, it largely draws on resources that were originally created through relations within their transnational social field. Here, they mediate the values of family coherence, accountability, selflessness, generosity, and piety (Keshavarzian 2007), which are crucial in their internal system of value since the early years of immigration to Hamburg. More recently, professionalism conveyed through good contacts to political and economic powerholders, as well as educational attainment became another important value. In the social field of Iranian foreign trade, these resources convey, besides piety, altruism, and family cohesion, also professionalism and wealth. In the German carpet market, in turn, they mediate authenticity and exoticism, but also familiarity, expertise, and accountability, while they may dissimulate their piety and their relations with the Iranian government. Thus, Iranian merchants' collective politics within systems of value that change often unexpectedly and in unpredictable ways led to a convergence of their collective agency in the Iranian and German social fields of the carpet trade that promotes some of the same resources on which they build their internal cohesion.

The collective narrative of the "traditional Iranian carpet merchants", I argued in the introduction to this chapter, puts forward Iranian identifications, a long business history in Hamburg, family cohesion, and professional know-how. During my fieldwork, I worked, for a few weeks, as a waitress in an Iranian restaurant in Hamburg. One day I had a memorable customer, a huge man in his fifties, who was accompanied by a heavily made-up woman with long, blonde hair. I noticed the Rolex he had ostensibly positioned in the middle of the table. He told me that he was a carpet merchant, and added that he was not Iranian but an ethnic Roma from a Balkan country. When I told Omid about the encounter, I was surprised by the vehemence of his reaction: 
Stay clear of these people! These gypsies lie! They always try to pass themselves off as Iranians. They say they are the nephews of such as such known carpet dealer and take the piss out of people. You should be very careful! (Field notes, October 2013)

The appropriation of the merchants' narrative-in particular its two main pillars, Iranian origin and business continuity through kinship ties-by people who identify as Roma but are not of Iranian origin, underlines its efficiency in creating capital.

The narrative is efficient, because it allows merchants to draw (in large part) on the same resources to create capital in the three social fields in which they are involved, although these are shaped by highly diverging systems of value. Indeed, due to changing local and transnational political, economic, and infrastructural conditions, and thanks to the merchants' collective politics of value, their migration-specific resources that represent an Iranian identity building on ideas of tradition and family cohesion today mediate the respective values that enhance the creation of capital for business purposes in each of the professional social fields. Conversely, following the principles of diplomacy and complaisant submission-acts of impression management-merchants downplay resources that fail to promote crucial values in these social fields and thus threaten to create barriers to capital creation. These are, for instance, religious piety in the German carpet market and oppositional political engagements in the social field of Iranian foreign trade. Ultimately, the efficiency of politics of value relies on creating a maximum of capital from existing resources, while keeping the effort of generating new ones minimal.

The discussion of the way Iranian merchants engage with shifting systems of value in the local and transnational social fields of Iranian foreign trade, the German carpet market, and among their peer Iranian merchants throughout seven decades sheds light on the workings of systems of value. As agents' power derives from their-inherently unequalpotential for action to determine the meaning of resources (Graeber 2001, 259ff.), I argued that value systems are produced by the interaction of agents pursuing malleable strategies of capital creation from unequal power positions. It became clear that both values and systems of value are ambiguous, ambivalent, contradictory, and, because they may shift at any 
time, transitional. Values do not stand for themselves. Their relations are shaped by interdependence, and, as some values occupy key positions respective to the mediation of other values, their strength and importance is unequal (cf. Dumont 2013; Hickel and Haynes 2018). Thus, for agents, mediating one value influences the mediation of others. The study of value in the context of capital creation shows that, just as values are ambiguous, so are resources: they can convey a single value or several values. They may as well convey a key value and simultaneously fail to mediate another crucial value. Barriers of capital creation come from unfulfilled crucial values.

As values are unequally important in one social field, so is the impact of barriers to capital creation unequal. The more central the value, the greater is the barrier to capital creation if it remains unfulfilled. Finally, I showed that dynamics in transnational social fields are highly interdependent and they mutually shape value systems. Systems of value interrelate when, as in the example to the Iran House project, social fields are overlapping, or when, as in the case of the values put forward by the Iranian monarchy, systems of value transgress the confines of a single social field. The potential for action of individual or collective agents lies thus in diplomatically crafting connections across systems of value through (sometimes arbitrary) value shifts with the help of fine-tuned politics of value in different social fields.

Karim, a 30-year-old barista of rather modest background, who came to Germany in 1986, told me that, among local Iranians, "the social status plays an important role. There are the upper classes: carpet merchants and intellectuals. They do not want to have anything to do with the others" (field notes, May 2013). Iranian merchants present a very particular case of collective capital creation, as their politics of value allow them to convey both familiarity and exoticism, that is, values that tend to be mutually exclusive in most social fields related to the German society. The next two chapters will show that post-revolutionary migrants who identify as "intellectuals" struggle with the opposition of these two values. The negotiation between different systems of value accounts for boundarymaking between these two "groups" of Iranians. 


\section{References}

Abrahamian, Ervand. 1982. Iran Between Two Revolutions. Princeton: Princeton University Press. 2008. A History of Modern Iran. Cambridge: Cambridge University Press. Adelkhah, Fariba. 1999. Being Modern in Iran. London: C. Hurst \& Co. 2016. The Thousand and One Borders of Iran: Travel and Identity, Iranian Studies. New York/Abingdon: Taylor \& Francis.

Adli, Abolfazl. 1960. Außenhandel und Außenwirtschaftspolitik des Iran. Berlin: Duncker \& Humblot.

Amuzegar, Jahangir. 1993. Iran's Economy Under the Islamic Republic. London: I.B. Tauris.

Anonym. 1961. Grab der Perser. Der Spiegel 40: 39-43. . 1971. Orientalische Tricks. Der Spiegel 35: 46-47.

Aumüller, Jutta. 2009. Assimilation: Kontroversen um ein migrationspolitisches Konzept, Kultur und soziale Praxis. Bielefeld: transcript Verlag.

Bauder, Harald. 2005. Habitus, Rules of the Labour Market and Employment Strategies of Immigrants in Vancouver, Canada. Social \& Cultural Geography 6 (1): 81-97.

Bodendiek, Erich. 1966. Des Schahs liebste Kunden: Der Orient bedrängt die deutsche Teppichindustrie. Die Zeit, February 9. http://www.zeit.de/1966/09/ des-schahs-liebste-kunden

Boltanski, Luc, and Eve Chiapello. 2005. The New Spirit of Capitalism. London/ New York: Verso.

Bösch, Frank. 2015. Zwischen Schah und Khomeini: Die Bundesrepublik Deutschland und die Islamische Revolution im Iran. Vierteljahrshefte für Zeitgeschichte 63 (3): 319-350.

Bourdieu, Pierre. 1997. Méditations pascaliennes. Paris: Le Seuil.

Brubaker, Rogers, and Frederick Cooper. 2000. Beyond 'Identity'. Theory and Society 29 (1): 1-47. https://doi.org/10.1023/A:1007068714468.

Classen, Walter, and Kathrin Voss. 1978. Dicke Perser - 'echt' wertlos. Die Zeit, March 1-5.

Comaroff, John L., and Jean Comaroff. 2009. Ethnicity, Inc, Chicago Studies in Practices of Meaning. Chicago/London: University of Chicago Press.

Cravatte, Céline. 2009. L'anthropologie du tourisme et l'authenticité. Catégorie analytique ou catégorie indigène ? Cahiers d'études africaines 193-194 (1-2): 603-620. 
Dabashi, Hamid. 2015. Persophilia: Persian Culture on the Global Scene. Cambridge: Harvard University Press.

de Jong, Sara. 2017. Complicit Sisters: Gender and Women's Issues Across NorthSouth Divides, Oxford Studies in Gender and International Relations. Oxford/New York: Oxford University Press.

Demurray, Enrico. 2008. Perserteppiche: Der Orient unter den Füssen. Documentary. NDR/ARTE.

Digard, Jean-Pierre, Bernard Hourcade, and Yann Richard. 2007. L'Iran au XXe Siècle: Entre nationalisme, Islam et mondialisation. Paris: Fayard.

Dobusch, Gabriele. 2010. Senator Stuth und das geplante Iran-Haus in Hamburg. Political party. SPD-Fraktion Hamburg, November 2. http://www. spd-fraktion-hamburg.de/no_cache/themen/europa/ kleine-anfragen/e/22029/f/6.html?tx_wfthpresse_pi1[pointer] $=1$

Drori, Israel, Benson Honig, and Ari Ginsberg. 2010. "Researching Transnational Entrepreneurship: An Approach Based on the Theory of Practice." In Transnational and Immigrant Entrepreneurship in a Globalized World, Benson Honig, Israel Drori, and Barbara Carmichael, 3-30. Toronto/Buffalo/ London: University of Toronto Press.

Dumont, Louis. 2013. On Value: The Radcliffe-Brown Lecture in Social Anthropology, 1980. HAU: Journal of Ethnographic Theory 3 (1): 287-315. https://doi.org/10.14318/hau3.1.028.

Erami, Narges, and Arang Keshavarzian. 2015. When Ties Don't Bind: Smuggling Effects, Bazaars and Regulatory Regimes in Postrevolutionary Iran. Economy and Society 44 (1): 110-139. https://doi.org/10.1080/030851 47.2014.909986.

Erdmann, Kurt. 1950. Der Teppich ein Garten: Letzte Zeugen der einstigen Blüte orientalischen Kunsthandwerks. Zeit, 33, August. http://www.zeit. de/1950/33/der-teppich-ein-garten/komplettansicht

Erel, Umut. 2010. Migrating Cultural Capital: Bourdieu in Migration Studies. Sociology 44 (4): 642-660. https://doi.org/10.1177/0038038510369363.

Fründt, Steffen. 2014. Das Millionenschwere Geschäft Mit Perserteppichen.

Die Welt, March 1, sec. Wirtschaft. http://www.welt.de/wirtschaft/article125322830/Das-millionenschwere-Geschaeft-mit-Perserteppichen.html Gerhardt, Peter, and Ahmet Senyurt. 2013. Gefährliche Geschäfte: Deutsche Deals mit dem Iran. Documentary. ARD.

Gholami, Reza. 2015. Secularism and Identity: Non-Islamiosity in the Iranian Diaspora, Studies in Migration and Diaspora. Surrey/Burlington: Ashgate Publishing Limited. 
Goffman, Erving. 1990. The Presentation of Self in Everyday Life. London/New York/Victoria/Toronto/New Delhi/Auckland/Johannesburg: Penguin Books. Göktürk, Deniz, David Gramling, and Anton Kaes. 2007. Germany in Transit: Nation and Migration 1955-2005. Berkeley/Los Angeles/London: University of California Press.

Graeber, David. 2001. Toward An Anthropological Theory of Value: The False Coin of Our Own Dreams. Hampshire: Palgrave Macmillan.

- 2013. It Is Value That Brings Universes into Being. HAU: Journal of Ethnographic Theory 3 (2): 219-243. https://doi.org/10.14318/hau3.2.012.

Grasseni, Cristina. 2005. Slow Food, Fast Genes: Timescapes of Authenticity and Innovation in the Anthropology of Food. Cambridge Anthropology 25 (2): 79-94.

Guilhot, Nicolas. 2005. The Democracy Makers. Human Rights and the Politics of Global Order. New York: Columbia University Press.

Guillaume, Marc. 1990. Invention et stratégies du patrimoine [Online]. In Patrimoines en folie, ed. Henri Pierre Jeudy. Paris: Éditions de la Maison des sciences de l'homme.

Halter, Marilyn. 2007. Shopping for Identity: The Marketing of Ethnicity. New York: Schocken Books.

Helfer, Walter. 1989. Zwischen Bazar und Moschee: Iraner in Hamburg. Documentation. NDR3.

Helfgott, Leonard M. 1993. Ties That Bind: A Social History of the Iranian Carpet. Washington, DC/London: Smithsonian Institution Press.

Henry, Sheila E. 1999. Ethnic Identity, Nationalism, and International Stratification: The Case of the African American. Journal of Black Studies 29 (3): 438-454.

Hertel, Michael. 2011. Bleibende Werte. Quartier 15 (November). http://quartier-magazin.com/quartier15/bleibende-werte

Hesse-Lehmann, Karin, and Kathryn Spellman. 2004. Iranische transnationale religiöse Institutionen in London und Hamburg. Ihr Einfluss auf das interkulturelle Zusammenleben. In Zuwanderung und Integration. Kulturwissenschaftliche Zugänge und Soziale Praxis, Münchener Beiträge Zur Interkulturellen Kommunikation, ed. Christoph Köck, Alois Moosmüller, and Klaus Roth, vol. 6, 141-162. Münster: Waxmann Verlag.

Hickel, Jason, and Naomi Haynes. 2018. Hierarchy and Value: Comparative Perspectives on Moral Order, Studies in Social Analysis. New York/Oxford: Berghahn Books. 
Iteanu, André. 2013. The Two Conceptions of Value. HAU: Journal of Ethnographic Theory 3 (1), (2013): Special Issue: Value as Theory (Part I). https://doi.org/10.14318/Hau3.1.010, June. https://www.haujournal.org/ index.php/hau/article/view/hau3.1.010

Ittig, Annette. 1992. Ziegler's Sultanabad Carpet Enterprise. Iranian Studies 25 (1-2): 103-135. https://doi.org/10.1080/00210869208701772.

Jacques-Jouvenot, Dominique, and Yvan Droz. 2015. Faire et défaire des affaires en famille: Pour une sociologie des très petites entreprises en milieu rural, Les Cahiers de La MSHE Ledoux. Chareton-le-Pont: Presses universitaires de Franche-Comté.

Kamalkhani, Zahra. 1988. Iranian Immigrants and Refugees in Norway. Bergen: University of Bergen.

Kelley, Ron, Jonathan Friedlander, and Anita Colby, eds. 1993. Irangeles: Iranians in Los Angeles. Berkeley/Los Angeles/Oxford: University of California Press.

Keshavarzian, Arang. 2007. Bazaar and State in Iran: Politics of the Tehran Marketplace. Cambridge: Cambridge University Press.

. 2009. Regime Loyalty and Bâzâri Representation under the Islamic Republic of Iran: Dilemmas of the Society of Islamic Coalition. International Journal for Middle East Studies 41 (02): 225-246. https://doi.org/10.1017/ S0020743809090643.

Khosravi, Shahram. 1999. Displacement and Entrepreneurship: Iranian Small Businesses in Stockholm. Journal of Ethnic and Migration Studies 25 (3): 493-508. https://doi.org/10.1080/1369183X.1999.9976697.

- 2008. Young and Defiant in Tehran. Philadelphia: University of Pennsylvania Press.

Kian-Thiébaut, Azadeh. 2005. Changements Familiaux et Modernité Politique En Iran. In Famille et Mutations Sociopolitiques: L'approche Culturaliste à l'épreuve, ed. Azadeh Kian-Thiébaut and Marie Ladier-Fouladi, 89-124. Paris: Editions de la Maison des sciences de l'homme.

Koch-Wegener, Anette. 2005. Apostle of the Free Market Economy: Ludwig Erhard Und Die Soziale Marktwirtschaft Aus US-Amerikanischer Perspektive, 1949-1955. Marburg: Tectum-Verlag.

Kunz, Egon F. 1973. The Refugee in Flight: Kinetic Models and Forms of Displacement. International Migration Review 7 (2): 125-146. https://doi. org/10.2307/3002424. 
Lambek, Michael. 2013. The Value of (Performative) Acts. HAU: Journal of Ethnographic Theory 3 (2), (2013): Special Issue: Value as Theory (Part II). https://doi.org/10.14318/Hau3.2.009, 3 (2): 141-60.

Lamphere, Louise, ed. 1992. Structuring Diversity: Ethnographic Perspectives on the New Immigration. Chicago/London: University of Chicago Press.

Light, Ivan, Georges Sabagh, Mehdi Bozorgmehr, and Claudia Der-Martirosian. 1994. Beyond the Ethnic Enclave Economy. Social Problems 41 (1): 65-80. https://doi.org/10.2307/3096842.

Marsden, Magnus. 2018. Civility and Diplomacy: Trust and Dissimulation in Transnational Afghan Trading Networks. Anthropological Theory 18 (2-3): 175-197. https://doi.org/10.1177/1463499618757895.

McAuliffe, Cameron. 2008. Transnationalism Within: Internal Diversity in the Iranian Diaspora. Australian Geographer 39 (1): 63-80. https://doi. org/10.1080/00049180701877436.

Moallem, Minou. 2000. 'Foreignness' and Be/Longing: Transnationalism and Immigrant Entrepreneurial Spaces. Comparative Studies of South Asia, Africa and the Middle East 20 (1-2): 200-216.

Mobasher, Mohsen. 2006. Cultural Trauma and Ethnic Identity Formation Among Iranian Immigrants in the United States. American Behavioral Scientist 50 (1): 100-117. https://doi.org/10.1177/0002764206289656.

Nieswand, Boris. 2011. Theorising Transnational Migration: The Status Paradox of Migration. New York/Abington: Routledge.

Nietzsche, Friedrich Wilhelm. 2003. Thus Spake Zarathustra: A Book for All and None, Classics Series. New York: Algora Publishing.

Norddeutscher Rundfunk. 1955. Shah Und Soraya in Hamburg. Parviz' Family Archives. NDR3.

Nowicka, Magdalena. 2013. Positioning Strategies of Polish Entrepreneurs in Germany: Transnationalizing Bourdieu's Notion of Capital. International Sociology 28 (1): 29-47. https://doi.org/10.1177/0268580912468919.

Ong, Aihwa. 1996. Cultural Citizenship as Subject-Making: Immigrants Negotiate Racial and Cultural Boundaries in the United States [and Comments and Reply]. Current Anthropology 37 (5): 737-762. https://doi. org/10.2307/2744412.

-1999. Flexible Citizenship: The Cultural Logics of Transnationality. Durham: Duke University Press.

OPT1001. 2012. 1001 Nacht Farhadian Hamburg dar "Ba Iranian"-Jam e Jam. Video. https://www.youtube.com/watch?v=4I7s22PXNr4 
"Original and Prominent Supporters." 2015. Stop the Bomb: No Deals with the Iranian Regime! http://de.stopthebomb.net/en/sign-now/original-supporters. html\#c324. Accessed 9 Apr.

Piehler, Moritz. 2009. Parviz Namdar: Wir spüren die Krise. Jüdische Allgemeine, May 20. http://www.juedische-allgemeine.de/article/view/id/821

Rezaei, Shahamak. 2009. The Marginalization of Globally-Born Businesses: Ethnically Divided Trade in Hamburg and the World Economy - The Case of Global Persian Carpet Trade Through Ethnic Networks. American Journal of Economics and Business Administration 1 (2): 79-96.

Robbins, Joel. 2015. Ritual, Value, and Example: On the Perfection of Cultural Representations. Journal of the Royal Anthropological Institute 21 (S1): 18-29. https://doi.org/10.1111/1467-9655.12163.

Rudner, Martin. 2010. The Modernization of Iran and the Development of the Persian Carpet Industry: The Neo-Classical Era in the Persian Carpet Industry, 1925-45. Iranian Studies 44 (1): 49-76. https://doi.org/10.1080/0 0210862.2011 .524491$.

Rushdie, Salman. 1989. The Satanic Verses. New York: Viking.

Sadjed, Ariane. 2012. "Shopping for Freedom" in der Islamischen Republik: Widerstand und Konformismus im Konsumverhalten der iranischen Mittelschicht, Kultur und Soziale Praxis. Bielefeld: transcript Verlag.

Sahlins, Marshall. 1972. Stone Age Economics. Chicago: Aldine Atherton.

Said, Edward W. 1978. Orientalism. New York: Vintage Books.

Sanadjian, Manuchehr. 2000. 'They Got Game' Asylum Rights and Marginality in the Diaspora: The World-Cup and Iranian Exiles. Social Identities 6 (2): 143-164. https://doi.org/10.1080/13504630050032044.

Schanzen, Birgit, and Frederik Keunecke. 2018. Die Nordreportage: Die Hamburger Speicherstadt größter Teppichumschlagplatz der Welt. Documentary. Nordeutscher Rundfunk. https://www.ndr.de/fernsehen/sendungen/DieHamburger-Speicherstadt,sendung691126.html

Schmidt, Jonas-Erik. 2013. Speicherstadt Hamburg: Treff von Teppichhändlern und Touristen. Manager Magazin, October 28. http://www.manager-magazin.de/immobilien/artikel/hamburger-speicherstadt-wird-125-jahre-alsa-929002.html

Schütt, Peter. 2000. Leuchtfeuer des Islam im Abendland: Die Imam-AliMoschee an der Hamburger Alster. Die Brücke: Forum für Antirassistische Politik und Kultur 116 (6): 40-44.

Smechowski, Emilia. 2010. Iranische Imagepflege: Der nebulöse Neubau. TAZ, October 28, sec. Nord. http://www.taz.de/!5133218/ 
Spillmann, Markus. 2003. Lokaltermin beim Orientteppichhändler Diahangir Momeni in Hamburgs Speicherstadt "Als Kaufmann bin ich neutral". Neue Züricher Zeitung, August 31. http://www.nzz.ch/article91B8C-1.296773

Spooner, Brian. 1986. Weavers and Dealers: The Authenticity of an Oriental Carpet. In The Social Life of Things: Commodities in a Cultural Perspective, ed. Arjun Appadurai, 195-235. Cambridge: Cambridge University Press.

Statistical Centre of Iran. 2014. Iran Statistical Yearbook 1392: 11. Trade \& Hotels. Tehran. http://www.amar.org.ir/Portals/1/yearbook/1392/11.pdf

Sywottek, Arnold. 1986. Hamburg seit 1945. In Hamburg: Geschichte der Stadt und ihrer Bewohner, Band II Vom Kaiserreich bis zur Gegenwart, ed. Werner Jochmann, 377-466. Hamburg: Hoffmann und Campe.

tkr/DPA/DPA. 2013. Geheimdokumente über Altkanzler: Kohl wollte offenbar die Hälfte aller Türken loswerden. Stern, August 2. http://www.stern.de/politik/geschichte/geheimdokumente-ueber-altkanzler-kohl-wollte-offenbardie-haelfte-aller-tuerken-loswerden-3372250.html

Universität Hamburg. 2014. Geschichte der Universität. Universität Hamburg. http://www.uni-hamburg.de/uhh/profil/geschichte.html.

Van den Bos, Matthijs. 2012. 'European Islam' in the Iranian Ettehadiyeh. In Shii Islam and Identity. Religion, Politics and Change in the Global Muslim Community, ed. Lloyd Ridgeon, 64-92. London/New York: I.B.Tauris.

Vertovec, Steven, ed. 2015. Diversities Old and New: Migration and Socio-Spatial Patterns in New York, Singapore and Johannesburg, Global Diversities. New York/Hampshire: Palgrave Macmillan.

von Goethe, Johann Wolfgang. 2010. West-East Divan: The Poems, with "Notes and Essays": Goethe's Intercultural Dialogues, Global Academic Publishing. Albany: State University of New York Press.

Werbner, Pnina. 1990. The Migration Process: Capital, Gifts and Offerings Among British Pakistanis. New York/Oxford/Munich: Berg Publishers.

Wolf, Peter Michael. 2005. Hamburger Teppichhandel in der Krise. Die Welt, March 31. http://www.welt.de/print-welt/article562656/HamburgerTeppichhandel-in-der-Krise.html

Younes, Anna-Esther. 2015. Die Anderen der Anderen - Antisemitismus und antimuslimischer Rassismus in Deutschland heute. In Gespräche über Rassimus: Perspektiven \& Widerstände, ed. Zülfukar Çetin and Taş Savaş, 123-138. Berlin: Verlag Yilmaz-Günay. 
Open Access This chapter is licensed under the terms of the Creative Commons Attribution 4.0 International License (http://creativecommons.org/licenses/ by/4.0/), which permits use, sharing, adaptation, distribution and reproduction in any medium or format, as long as you give appropriate credit to the original author(s) and the source, provide a link to the Creative Commons licence and indicate if changes were made.

The images or other third party material in this chapter are included in the chapter's Creative Commons licence, unless indicated otherwise in a credit line to the material. If material is not included in the chapter's Creative Commons licence and your intended use is not permitted by statutory regulation or exceeds the permitted use, you will need to obtain permission directly from the copyright holder.

(c) (i) 


\section{4}

\section{An Association Between Diversity and Exoticism}

At the end of the last concert of the three-day FusIran festival, which the Golestan association co-organized in one of Hamburg's most important nightclubs, Shahrokh Moshkin Ghalam dances to the music of the Italybased classical Iranian music group Barbâd. He wears a dark grey dervishlike dress; his waist-long hair is swirling. Spontaneously, the dancer invites female members of the association to join him onstage. Shahla is the first to join. I am surprised, because she told me that she did not know how to dance to Iranian music at a party a month earlier. Then, Said Shanbehzadeh, who performed the previous concert of Southern-Iranian Bandari-style music, jumps on the stage. The Paris-based musician has exchanged the simple cloth reminding African tribal clothes for a beige costume. As I walk around in the crowd of about 200 persons (according to Sadegh the public was constituted to $70 \%$ of Iranians and $30 \%$ of Germans), Yalda meets me and says: "Go, join the others on the stage!" I am embarrassed, but I go anyways as virtually all Golestanis including some of their family members are dancing together with the artists, thus symbolically concluding the festival. (Field notes, October 2013)

The moment I stepped on the stage, it felt as if I was part of a group united not only by the celebration of the successful completion of three 
intense days of volunteering. Dancing with these internationally renowned Iranian artists-Moshkin Ghalam and Shanbehzadeh reinterpret Iranian traditional and folk culture ${ }^{1}$ for Western and Iranian migrant publics — was also a way for each member to individually show his identification with neo-traditionalist Iranian cultural elements in front of the public. In that instant, we, the dancing Golestanis, were united through our situational collective identification.

Since the mass immigration of the 1980s, Iranians' continuously growing diversity of social backgrounds, levels of education, ethnic identities, religious and political beliefs give rise to a proliferation of Iran-related associations in Hamburg. There are cultural and ethnic associations, professional unions (like the Union of Iranian Entrepreneurs, see Chap. 3), religious groups (the association of the supporters of an Iranian-Shia mosque), and political associations. During my fieldwork, I repeatedly heard people report about conflicts within these associations. For example, Ehsan, a 50-year-old academic, told me that, several years ago, the literature circle Hamneshast split over the disagreement of two board members. Babak, an artist in his early forties, told me that he did not join Hamneshast although the topics it treated interested him, because "there are always people who spoil it [for me]; conservative people who play to the gallery" (field notes, April 2013). Given the great diversity of individual trajectories and the multiplicity of identifications among Iranians in Hamburg, what boundaries do people mobilize to create and maintain collective identifications within such a migrant association?

According to Pierre Bourdieu (1979, 182, 355), in associations and clubs organized around a common activity or feature, social distinction can be studied through processes of inclusion and exclusion. Indeed, associations are spaces where members can create capital (idem 1979, 533). More specifically, one can build networks and acquire new skills and cultural knowledge, for example, organizational know-how and language skills, and thereby gain a greater participation in the society of residence, and, if applicable, in transnational social fields (Cattacin and

\footnotetext{
${ }^{1}$ While Moshkin Ghalam mixes traditional Iranian, Sufi, Flamenco dance elements with martial arts styles, Shanbehzadeh performs folklore music and dances from the southern Iranian province of Bushehr.
} 
Domenig 2014; Prashizky and Remennick 2015). While migrant associations are mostly based on a shared identification with a national or ethnic category, their collective identity references often contain elements both of the society of origin and of the place of residence (Cattacin and Domenig 2014).

So far, my research illustrated that ethnic and national identifications, informed by personal experiences and professional trajectories, are tools within flexible strategies of capital creation. In the context of carpet merchants of Iranian origin, I showed that collective identifications-in the form of professional narratives - may emerge, as a way to engage in politics of value that serve to fine-tune the values certain resources mediate and thus navigate the simultaneous capital creation in several social fields. Consequently, agents' politics of value constitute the motivation that drives their performance of capital creation. Extant research shows that, in providing collective identity references, migrant associations propose cultural representations that may help to overcome certain barriers to capital creation (Ghorashi 2004; Amelina and Faist 2008, 113f.). My aim in this chapter is to examine how processes of evaluation within an association relate to systems of value that prevail in the social fields relevant for the association's activities.

Understanding boundary-making as the denial of a resource's value, and the deconstruction of a boundary as the valorization of a resource as a capital, I examine the inclusion and exclusion of people in the Hamburg branch of the German-Iranian association Golestan, from its foundation in 2011 until 2015. Through a diachronic analysis, I trace how members, post-1979 highly educated first- and second-generation migrants, individually and collectively put forward different identifications in relations with German media, among established Golestanis, and in contact with prospective members. Thus, interrogating the formation of group identifications from within, I aim to shed light on the way unequal individual resources drive the collective potential for action in politics of value in the German public sphere, in the local Iranian social field, and the transnational social field of Iranians identifying as honari.

I first learnt about Golestan through Roshan, a woman in her early thirties, who had been my flatmate a few years before the association was founded. She posted an advertisement for their annual Nowruz festivity 
on Facebook. Intrigued by its venue, unusual for Iranian events (a Steiner school), I joined the celebrations that took place in March 2013. In this frame, I met Babak, who invited me to join Golestan's first Stammtisch ${ }^{2}$ in May 2013, after we met several times over a coffee or a beer. Situations in which I felt included in group dynamics became more and more frequent in the course of research. This was not only due to my regular attendance of the monthly Stammtisch, but also to my participation in private meetings, barbecues, and nights out with some of the Golestanis. My involvement became more important through my volunteering in the organization of the three-day-long FusIran festival and the 2014 Nowruz festivities. Yet, to learn about the beginnings, I had to draw on interviews and media documentation.

\section{New Beginnings in Old Familiarity}

In the frame of the 2009 protests in Iran that accused the government of election fraud, Donya, a physician, and Sadegh, a successful poet and writer, respectively 34 and 39 years old, engaged in different forms of transnational activism in Hamburg. Their move reflects a growth of interest in Iran-related associations among young people of Iranian origin all over the world within this social upheaval (Alexanian 2011; Kelly 2011, 450f.). However, both told me that they soon reached the social and political limits to this kind of activism. As they shared the idea of engaging in cultural, rather than outrightly political work, their common friend Babak introduced them to each other. Sadegh suggested founding a local branch of Golestan, an association his friend Davud, an editor, was creating in Munich. In doing so, he explained me, he wanted to reduce administrative work and prevent struggle over the association's leading principles:

The [Golestan association] intends to be a place where German-Iranians can pursue those longings which they are not able to fulfill elsewhere.

\footnotetext{
${ }^{2}$ Stammtisch is a German concept, referring to the regular meetings of a stable group of people in the frame of associational or friendship circles - a concept that has parallels to the Iranian dowreh. Distinct from Golestan's official members' meetings that took place behind closed doors, the idea of these gatherings is to offer an open space for people interested by the association in which they can get acquainted with its members in an informal setting.
} 
At [Golestan] we would like to create a space where we can further develop our individual concept of the term "home" [...]. It's [Golestan's] goal to provide a place for [...] diversity. A place where it can be experienced not only by German-Iranians but also by "native" Germans as well as people with a German-French, German-Turkish, German-Ghanaian (etc.) background [...]. One of [Golestan's] main goals is to provide a forum for a dialogue between cultures. It is a place of mutual respect and common experiences, where different views and concepts of life are tolerated. (Website of association Golestan, assessed 07/11/20153)

In other words, the association's declared aims were to provide identifications for people of Iranian origin, and a space where people of any ethnic background can live and experience the diversity of what is defined as "Iranian culture".

Seven people of Iranian origin, aged between 25 and 41, and linked by kinship or long-term friendship, created Golestan's Hamburg branch in 2011: Donya, her sister and brother, Sadegh, Roshan, her brother Afshin, Yalda, a female journalist called Shahla, and Babak. Some came to Hamburg as young adults; others were born in Germany or raised in different countries in the West. Donya explained "these were all people I knew and trusted" (interview, November 2015). She said that all were either themselves left-wing Iranian regime-critical activists, or their family members, or both. They were university-educated professionals or students and shared an interest in art. Many actually had personal ties in the Iranian artist milieu: Donya had set out to be a professional piano player before her migration, Sadegh and Babak had participated in art productions in Iran, and Yalda occasionally worked as a piano teacher in Tehran. Others, like Roshan and Donya's brother, were amateur dancers. Plus, Donya's uncle had worked with Yalda's father in Iran. Thus, as frequently observed in research on migration (Moya 2005; Kelly and Lusis 2006, 841 ), the association was originally based on pre-migratory social networks.

Their shared ties to Iranian artist subculture testify of an urban salaried middle-class background in Iran (Tehran and Shiraz), and identitary links to the intelligentsia (rowshanfekrân). Ervand Abrahamian (2008,

\footnotetext{
${ }^{3}$ In order to maintain the anonymity of the association, I do not indicate the web address.
} 
34ff.) dates the origins of this identitary group, which draws on a dialectical opposition to the propertied middle class, the merchants, back to the presence of foreign military and economic powerholders in Iran in the nineteenth century. A picture from 2012 that figures on the association's website shows some of the foundation members including Yara. They pose in front of a building covered with graffiti, probably located in the Schanzenviertel, a district marked by undergoing gentrification, where alternative subcultures meet yuppie lifestyles (Naegler 2012), thus underlining their linkage to local alternative culture. Moreover, Yara's green jacket and Yalda's green scarf support the protestation movement against the elections in $2009 .{ }^{4}$

Associations serve as sites of distinction; this is also the case for migrants. Anna Prashizky and Larissa Remennick (2015), for instance, show how among young people of Russian origin in Tel Aviv create an association to collectively reinterpret a culturally hybrid Russian intelligentsia lifestyle. In doing so, they draw boundaries to Russians with different social and migratory trajectories, and they aspire for upward social mobility through the recognition of their Russia-related cultural capital by local Israelis. Such a recreation of socio-professional identities after migration is reminiscent of Iranian carpet merchants' politics of value. Trust created through long-term relations plays a crucial role here, too. However, we shall see why, at the difference of carpet merchants, Golestanis seek to stress their Germany-specific capital or claim cosmopolitan, rather than primarily Iran-related tradition-orientated identifications. Thereby, the mobilization of the system of value that prevails in the transnational social fields of Iranian artists, in other words, the local reinterpretation of the "honari imaginary", plays a crucial role in the association's original politics of value.

\section{A Honari Imaginary}

When I attended Golestan's Nowruz festivities in 2014, I had just come back from a research stay in Iran. The event featured a stand on which I recognized some of the same handcrafted goods-jewelry, scarves, key

\footnotetext{
${ }^{4}$ Green was the color of the unsuccessful reformative candidate Mir-Hossein Mousavi.
} 
fobs, and so on-I had seen on one of the biggest markets of small artisans in Tehran, pâssâj parvâneh. I was told that one of the newer members had brought them back on her last visit. As this instance indicates, the members' personal connection with the transnational Iranian art milieu influenced the choice of Iran-specific resources Golestan put forward. Significantly, according to Donya, one of Golestan's initial aims was to offer a platform to contemporary young artists, who lack the permission of the ministry of culture and Islamic guidance to work legally in Iran. The FusIran festival was supposed to be such an occasion.

To understand the role of this identification in dynamics within the association, we have to take into account which values these art-related resources mediate in Iranian contexts. Obviously, the complexity of the social dynamics in Iran's art milieu would require a research on its own (see Emami 1986; Grigor 2012). For the purpose of this chapter, I confine myself to drawing the great lines of the honari imaginary which developed around this artist milieu. I chose the term "imaginary" to account for the constructiveness and fluidity of the ideas and practices that shape identifications with artistic subcultures.

I first got in touch with people who call themselves - and are identified as-honaris ${ }^{5}$ thanks to some of my family members living in Iran, who are art professionals or amateurs. Ideas and practices that refer to honari identifications are highly diverse, but, without falling into simplifications, I will identify a few recurrent markers. First, the common ground on which such identities rely is an interest in the fine arts, at least in the general sense. This interest implies a rather high level of education, often linked to a middle-class background.

Second, many people who identify as honaris valorize Iranian traditional (sonnati) cultural elements (in particular literature, folklore music, folkloric designs) as well as European high culture (e.g. Italian architecture, French literature). This neo-traditionalism may go together with a distancing from the global Western-oriented consumer culture (Sadjed 2012, 156). Babak, for example, told me that when he is in Iran, he likes to spend his evenings at the café of the "Mohsen art gallery" located in a

\footnotetext{
${ }^{5}$ The term is best translated as "arty people", which, in contrast to artists, honarmandân, includes also amateurs.
} 


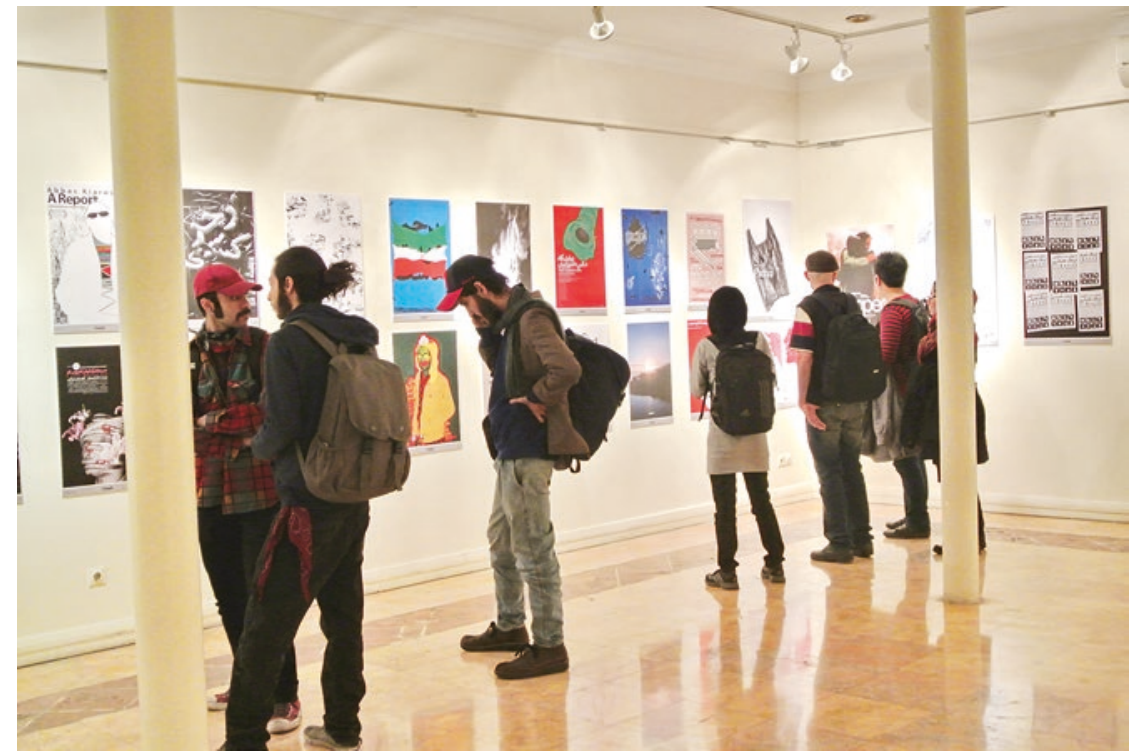

Image 4.1 Young men whose clothing and hairstyle mark their honari identification at Khâneh honarmandân, center of contemporary art, Tehran. (February 2014, author's photo)

high-end quarter in Northern Tehran and specialized in avant-garde art, because "you can meet people there who are less consumption-oriented as the rest of the society" (field notes, March 2014).

In Iran and abroad, people enact the honari imaginary through consumption practices, ${ }^{7}$ which may contain elements that can be found in Western alternative subcultures. For example, wearing colorful and large clothes inspired by Iranian folklore may evoke Western hippie styles. Large glasses, as well as beards and mustaches for the men do not only reflect Iranian neo-traditionalism but also the influence of the Westernoriginated hipster trend (Image 4.1).

Gendered behavior that contests patriarchal and Islamic norms is also a way for honaris to seek distinction from urban mainstream lifestyles. For

\footnotetext{
${ }^{6}$ Babak "Da trifft man Leute die nicht so konsumorientiert sind wie der Rest der Gesellschaft".

${ }^{7}$ Public locations in which I could observe people displaying such a lifestyle are (clandestine) cafés, tea houses, parks, art galleries, theaters, or handicraft markets in Tehran and Mashad.
} 
example, while physical closeness between non-related persons is considered sinful (harâm) according to Islam, in winter 2013, I saw a male friend and colleague of a female graphic designer-ten years her junior-spontaneously kiss her on the forehead on a street near Tehran's Vanak Square.

In sum, identifying as honari tends to mean putting forward certain social and cultural resources that would mediate education, knowledge of Iranian (pre-Islamic) traditions, literature, acquaintance with Western high culture, and its values of democracy, equality, human rights, and sometimes even socialism (Abrahamian 2008, 35). Simultaneously, the same people downplay resources that would convey Islamic piety, political loyalty to the Iranian government, patriarchy, but also global cultural hierarchies, or capitalism as these contradict the aforementioned key values within the system of value that shapes honari contexts (see also Sadjed 2012, 156f.). It thus tends to express opposition or at least a critical stance toward the Iranian regime.

In recent years, however, the honari lifestyle became part of a more mainstream urban neo-traditionalist trend in Iran. Significantly, 15 years ago, shops selling artistic and craftwork could be found only in rare touristic places or traditional workshops. However, I noticed a burgeoning of stores selling (rather expensive) pottery, jewelry, locally designed folkloreinspired clothes and leatherwork in big cities since the mid-2000s (Image 4.2). ${ }^{8}$ This development is the result of several — quite contradictorysocial and political influences. First, the government encourages a revival of "authentic Iranian culture" as a nationalist resistance against Westernization, in particular in artistic productions (Keshmirshekan 2010, 492). We saw some of this politics in the governments' hailing of carpet knotters in Chap. 3. Second, the identification and revival of preIslamic Iranian cultural elements among people of Iranian origin living in Western countries, which Kathryn Spellman (2004, 43) calls the "syncretic re-archaization", stimulates this interest. ${ }^{9}$ Thus, the neo-traditional tendencies in Iran led to the increasing commercialization of artists' and

\footnotetext{
${ }^{8}$ Shahram Khosravi $(2008,69)$ also testifies about the appearance of traditional tea houses (châi khâne-ye sonnati) in Tehran's Northern high-end districts.

${ }^{9}$ There is, for example, a new interest in Zoroastrian festivities such as Tirgân and Mehregân among urban middle classes. Significantly, my father told me in 2013 that he had participated in an outdoor Tirgân festivity with a hundred other people in the Northern province of Mazanderan-a festivity which he had known neither in his youth in Iran, nor during the time he lived in Germany.
} 


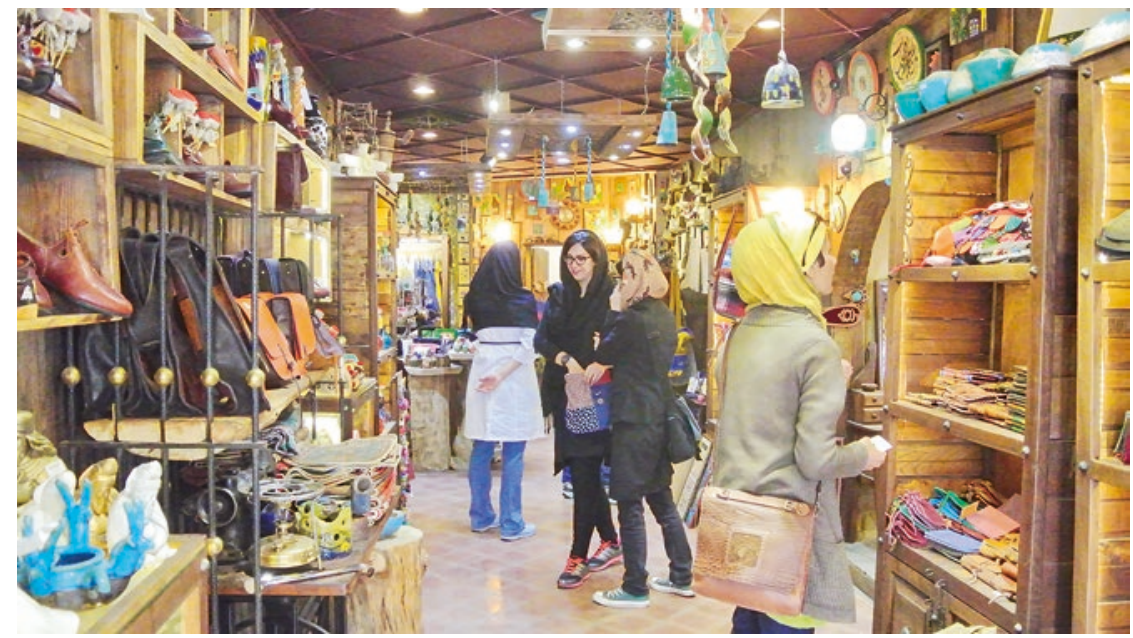

Image 4.2 A store in central Tehran selling honari artifacts. (February 2014, author's photo)

artisans' work, bringing images linked to their lifestyle to the center of society.

Having thus outlined the Iranian identifications the founder members sought to promote, I move on to examine the interaction between individual members' identifications within a German public media appearance, in order to set the context for the subsequent analysis of internal boundary-making.

\section{A Public Negotiation of the Limits to Identifications}

One year after its foundation, in mid-2012, the Golestanis Afshin and Yara participated in a TV program, which has the aim to present nonprofit organizations' projects to prospective donors and sponsors. Besides members of Golestan, there was also the vice-president an association of people from Burkina Faso.

Afshin, a founding member, is an introverted 28-year-old student of law. As opponents to the Islamic Republic, his parents sought asylum in 
Hamburg, where he was born and raised. Like Roshan, Afshin was my flatmate a few years before I started this research. Three years older Yara, who I met during my fieldwork, joined Golestan a few months before its first public event. The educator was born in Iran, came to Germany with her family at the age of five, and grew up in Lüneburg, a city south of Hamburg. The family then moved to Hamburg in the mid-2000s. Contrary to Afshin's parents who strictly oppose Islam, Yara told me that her mother, today member of a local female Iranian folklore band, regularly took her to the Iranian mosque in Hamburg when she was a child. Afshin never went to Iran, but Yara traveled there once when she was 21. However, she told me that, in engaging into anti-government activism in Hamburg in the frame of the 2009 upheaval, she resigned to not being able to go there anymore. Thus, both Golestanis can be considered second-generation migrants with German citizenship. However, their stances toward Iran and their engagement in local Iranian social fields could hardly be more different: Afshin has been keeping distance from Iranian contexts, and his friends are of various ethnic and national origins. His participation in Golestan was a first step toward an engagement with local Iranians. As for Yara, she has been strongly engaged in Iranian social fields since 2009.

In her introduction to the talk show, the journalist-a German without migration experience-quickly introduces the associations. Then, however, she questions Afshin and Yara about their Iranian identifications, asking:

Where are you from?

and to Afshin,

You were born here - how much Iranian is there actually still in you?

and to Yara,

You came to Germany at the age of five. How do you feel? Somewhere in between? 
The journalist sets out to focus on Afshin's and Yara's Iran-specific resources. Her first questions show her interest in their mediation of exoticism. As we saw in the previous chapter, this value was created through centuries of exchanges between Europe and the Middle East and closely connects to the quest for the culturally authentic (Halter 2007).

How did the Golestanis engage with this categorization? Afshin's strategy is to withdraw any ethnic or national significance from resources which the journalist interprets as Iranian:

I absolutely don't like to speak with [i.e. in terms of] "somehow being German or Iranian or so". Um, of course there is some kind of rootedness, my parents are from there, but ultimately, I was socialized here, I grew up here, and it is here that my life takes place [...]. So, it's not that we [i.e. Golestanis] only address Iranians - if you want to speak like this, in these categories - but actually all people who somehow identify with and who somehow look for a platform where this mix, precisely this "not clearly fitting somewhere" is echoed.

Afshin's refusing to adhere to any strictly defined ethnic or national identity is infused by his postcolonial understanding of nationhood and identity, not least through his sister's anti-racist activism in the group kanak attak ("wog attack"). Afshin tries to redefine the value mediated by non-European resources from exoticism toward diversity, and ultimately, familiarity. In doing so, he participates in a form of activism that grew popular in German-speaking contexts in the 2000s, as Fatima El-Tayeb (2004) and Sabine Strasser $(2006,2008)$ document. To be precise, I am here referring to diversity as a value ${ }^{10}$ (that is increasingly used in politics and public discourse (Schiller 2016; Bührmann and Schönwälder 2017)), which implies an acknowledgment of variety from the vantage point of adherence to a particular local cultural context. Significantly, in trying to turn the conversation away from his individual case, toward the identity of Golestan, Afshin defines the association as "not exclusively Iranian". Contrary to Afshin, Yara presents herself as German, but simultaneously indicates the limits to this identification:

\footnotetext{
${ }^{10}$ When I refer to diversity among Iranians, I intend the diversity of positioning in internal relations in the sense of plurality.
} 
I always say "I'm German" and then... I mean it is funny because people look at me and say "Well, you don't really look German." My question then is always "What does 'German' look like?" I mean, I'm German! If I feel this way, that's also what I am [she laughs].

Yara has black hair, dark, brown eyes, her skin has an olive tone, and she speaks German without any accent. The evaluation of her racial features thus became the reason why her interlocutor did not recognize the value of familiarity in her Germany-specific resources (see also Ong 1999, 91). In this TV show, she recounts these dynamics as a funny anecdote, but during my fieldwork I witnessed her being deeply affected by similar experiences. Boundary-making based on racial and religious difference is very common in German society and it constitutes important obstacles to migrants' capital creation (Weiss 2001; Goldberg 2006; Mandel 2008; Shooman 2014; Çelik 2017).

The first interactions between the journalist and the Golestanis raise a dichotomy prevalent in conceptions about immigration in Germany, which Martin Sökefeld (2004) termed the "paradigm of cultural difference": identifying as German and having other ethnic or national identities tends to be seen, if not as impossible at least as incompatible. I previously argued that, within German approaches to immigration, assimilation ultimately promotes the value of familiarity (see Chap. 3). Let me elaborate on this argument. In comparing the nature of symbolic boundaries against immigrants in Europe, Christopher Bail $(2008,49)$ shows that in Germany, education, occupational achievements, and, importantly, Germany-specific cultural resources, such as language skills and cultural knowledge, are seen as criteria for successful integration. Thus, familiarity is a key value and its mediation is essential to capital creation in dominantly German social fields. ${ }^{11}$

Moreover, the exotic and the familiar are perceived as mutually exclusive. Assimilation tends to be seen as the migrants' responsibility rather than as a collective process (Gruner 2010, 285; El-Tayeb 2016). This development is reflected in recent modifications in

\footnotetext{
${ }^{11}$ A similar importance of location-specific resources and the tendency to deny recognition of resources created abroad was observed in Sweden by Maja Cederberg (2015) — in spite of the government's political valorization of diversity.
} 
German citizenship legislation. Until the year 2000, citizenship was acquired primarily through filiation, based on the jus sanguinis. ${ }^{12}$ After that date, a legislative reform introduced the jus solis-the acquirement of citizenship through the birthplace (Bundesministerium der Justiz und für Verbraucherschutz 2015). However, dual citizenship is restricted to only those few nationals, whose country of origin makes expatriation difficult if not impossible, like Iran (Gaserow 1995). In short, the legislation suggests that you can be a German or a foreigner, but only with great difficultly can you be both. Correspondingly, resources created in transnational social fields tend to be perceived as unfamiliar and thus as a proof of a failure to assimilate (Ehrkamp 2006; Çelik 2015). Hence, in the system of values that shapes the German public sphere, that is, the social field in which the TV channel's production participates, Golestanis cannot both be Germans and be Iranians, nor can they be neither.

Because of this dichotomy, both Afshin and Yara resist the identification as Iranian and thereby contest their Iran-specific resources mediating exoticism. They aim to create, within Golestan, something Nicholls and Uitermark (2016) termed "counterpublic". We can think of it here as a social field whose system of value builds on an opposition to contexts in which their Iran-specific resources and racialized difference is perceived as a lack of familiarity. Yet, we will see in the following that, beyond the interest in not conveying exoticism, Afshin's and Yara's politics of value, and consequently, their strategies of capital creation, diverge.

Initially, the journalist shows interest in the Golestanis' contestations, for example, in suggesting the creation of a new social category that may reflect their cultural in-betweenness. However, instead of talking about the work of Golestan, or about aspects of Afshin's and Yara's life that are not related to Iran, she soon returns to inquiring about their "Iranianness", but now addresses Iran-related political issues:

\footnotetext{
${ }^{12}$ Accordingly, people who, like Afshin, were born to foreign nationals on German territory had to go through a formal citizenship application procedure to gain a German passport. This contributed to the categorization of children of migrants born and/or raised in Germany as foreigners, rather than Germans (Çelik 2015).
} 
Iran unfortunately also makes the headlines. Mahmoud Ahmadinejad, the dictatorship... that is unfortunately what the normal citizen knows about Iran since 2005. Do people ask you frequently about this?

\section{And}

How do you feel when you are, so to say, in Germany and talk is about Iran? With what feelings do you follow such news?

Essentially, the journalist refuses both Afshin's and Yara's identifications and continues to consider them as Iranian. Moreover, she uncritically raises popular preconceptions about Iran (and Burkina Faso ${ }^{13}$ ), judging the right and wrong of ideas and practices that do not correspond to the values of democracy and human rights. To defuse the journalist's judgment, Afshin and Yara state that, in their own social environment, people would have more nuanced images of Iran. In other words, the systems of value that shape the social fields in which they are engaged in their everyday lives are distinct from those prevailing in the German public sphere.

The journalists' evaluation of Iran-specific resources brings us to the second reason for the Golestanis' rejection of their categorization as Iranians: while these resources may convey exoticism, they also may be perceived as failing to convey the values of democracy, human rights, and equality-ultimately, familiarity with German contexts. Moreover, in the German public sphere, the value of exoticism is subordinated to the central importance of familiarity. In the case of carpet merchants, I showed that failing to mediate these values tends to create a barrier to Iranians' capital creation, for instance in the context of the Iran House project. Building on Iran-specific resources to convey exoticism is thus a risky strategy. Thus, Afshin's and Yara's politics of value aim at circumventing this potential barrier to capital creation by trying to convey familiarity, either in emphasizing the non-ethnic character of their Iran-specific resources and conveying diversity, or by putting forward Germany-specific resources. As the interview continues, Afshin sticks to his rejection of

\footnotetext{
${ }^{13}$ For example, in talking about Burkina Faso, the journalist inquires about female genital mutilation.
} 
national or ethnic categories against the journalist's quite insisting questions in an increasingly sarcastic way:

It's not as if, because my parents are from Iran, I am the one in charge of informing people about the actual state of the nuclear conflict. This is absurd, really.

He rebukes the journalist:

Journalist "Is there something where you would say [two seconds of hesitation] 'Iranians are really good in this, or one has to see that'?"

Yara [laughs].

Afshin "Now you hit on exactly the same line of argumentation that I just mentioned. I mean, there is no such thing as a 'typical Iranian this or that'."

At this point, Yara changes her politics of value. She gives up on trying to mediate familiarity. In a cheerful tone, she presents her Iran-specific resources in a way for them to convey the value of exoticism by putting forward Iran's ethnic and linguistic diversity.

We want to show a different image of Iran. I mean, um, our Iranian nation is a potpourri [kunterbunt], we have a multiethnic state, we have many, many languages in Iran that I even may not understand... we are really a potpourri, and that's exactly what we want to convey.

The effort to redefine the meaning of resources is a collective response to stigmatization frequent among ethnic minorities (Fleming et al. 2012). Significantly, like Yara, the invitee from the Burkina Faso association also engages in "identity entrepreneurship" (Brubaker and Cooper 2000). Research on Iranian associations and public events in the USA and the Netherlands equally suggests that they are sites for the production of Iranian identifications alternative to negative images prevailing in the media (Ghorashi 2004; Ghorashi and Boersma 2009; Malek 2011). As Yara draws an ethnic, that is, tentatively non-political, picture of Iran, and explains that her family identifies as ethnic Azeri, she accepts her categorization as Iranian (note also the usage of the first-person plural in 
the previous and the following citations). She distances herself from the Iranian government in order to sustain the values of democracy, human rights, and equality. In sum, Yara ends up complying, instead of engaging with the system of value that shapes this public media broadcast. As Nicholls and Uitermark $(2016,9)$ indicate, "rather than carving open a space in the public sphere, the expression of an identity that stood in opposition to dominant norms resulted in closure" and most often migrants resolve to conform to the expectation of exoticism and the struggle toward the impossible fulfillment of assimilation and familiarity.

For his part, Afshin successfully continues to reject any strictly defined national or ethnic identification, until, at the end of the interview, the journalist touches on his parents' political exile. As he shows personal affectedness for the first time, she comments in a pitiful tone that those who are forced to flee "leave something behind"-a statement that reflects stigmatization of people categorized as political refugees. This time, Afshin does not contest the journalist. However, Donya remembers that he was very angry after the broadcast, asking what the point of his participation was. Ultimately, in drawing on the value of diversity, he uses a concept that is itself a substantial part of discriminatory approaches to immigration, as Suzanne Hall (2017) notes. The Golestanis' persistent ascription to an assumed cultural alterity reveals that, within the system of value that shapes the German public sphere, resources that convey exoticism are less efficient, lasting, and versatile in creating capital than those who convey familiarity. The ultimate failure of both Afshin and Yara to mediate familiarity highlights their limited potential for action within social field that are shaped by this system of value.

Finally, their individual ways of engaging this system of value in the context of this TV show also indicates diverging ideas about Golestan association. While Afshin sees in the association a space for celebrating diversity as familiarity through activities that only loosely relate to the Iranian cultural context, Yara views it as a platform for exclusively Iranian contemporary art and cultural performances that cater to the mediation of exoticism.

It is on the background of navigating systems of value that promote familiarity while making it quite impossible for migrants to convey that we need to understand the negotiation of collective identifications within the association. 


\section{The Conflict}

In the process of collective identity formation, a conflict led to a split in the group between late 2012 and early 2013 and set the common ground on which collective identifications from then on would be negotiated. Roshan, who has a critical distance for being a PhD student abroad since 2012, resumed the conflict as follows:

As I think about it now, it was really a lot about identity negotiations, both about personal Egos, and about collective Egos in relation to Iran. (Private message on Facebook, October 2015)

Roshan's brother Afshin was the first to quit Golestan in late 2012. As became clear in the previous section, in the association, Afshin wanted to create a counterpublic which could reshape the dominant systems of value in German society by promoting diversity as familiarity. Significantly, Babak commented about him:

When he was at Golestan, he only complained about everything - the typical problem of leftist people. He wanted to make it more intercultural. What do I have to do with North Koreans? An association has a goal. I do that for a specific reason. To build up a network. [For me it is] not like [for] people like him, who are familiar with the place - this is their country, their language, their parents live here. But we need such networks. (Field notes, April 2013)

Thus, Babak attributes the difference between his own and Afshin's conception of Golestan primarily to the latter's political orientations which he qualifies as being too left-wing, or him being born in Germany-in other words, disposing of more Germany-compared to Iran-specific resources. As became clear in the preceding sections, the national or ethnic origin of resources plays a major role in their evaluation in the German society. Therefore, they are also highly relevant in social differentiation between Golestanis (see also Ehrkamp 2006).

In the case of the two men, their different disposition and volume of resources and their engagement in distinct social fields gave rise to poli- 
tics of value that engendered conflicting strategies of capital creation. While both men met with barriers to capital creation based on their categorization as Iranians in many German contexts, German-born Afshin disposed of less Iran- and more Germany-specific resources than Babak. His chances to circumvent these barriers by mediating familiarity, through his local rootedness for instance, were thus relatively better than those of his older peers. For his part, Babak, who grew up in Iran, had accumulated frustrations for failing to overcome the barriers his Iran-specific resources posed to his capital creation. In co-founding Golestan, he told me that he wanted to create a network of Iranian professionals in the art sector-a social field whose system of value would acknowledge both his Germany-specific and his Iran-specific resources as capital, and which would help to balance barriers in German contexts and simultaneously sustain the value of exoticism.

Initially, Roshan, Donya, and her siblings supported Afshin's nonexclusive approach to the association's Iranian identifications, while Babak, Sadegh, and Yara, who entered the association in early 2012, argued for a greater focus on Iran. This relative balance changed when, after its first public event in March 2012, more and more people joined Golestan (through a mandatory written application): there was Golzar, a 41-year-old makeup artist, who came to Hamburg in the early 1990s, and brother Mahyar, a recently graduated lawyer on job search. Ayda, a woman in her early thirties plays the santur, ${ }^{14}$ and Farzan, an engineer in his mid-thirties, were also among the new members. All of them nourished Azeri identifications, but ethnic identities never played a role in the association. Finally, there were 23-year-old Said, a student of informatics, and Younes-respectively German-born and born to a binational couple in Iran. Except for Younes, the newer members, although mostly university-educated, were of more modest origin, less politicized, less successful in generating capital in German social fields than most of the founders. On the whole, the newcomers were interested in fostering specifically Iranian collective identifications, following politics of value similar to Babak's. Thus, Afshin's interest in promoting non-ethnic diversity as familiarity conflicted with the interests of a growing number of mem-

\footnotetext{
${ }^{14} \mathrm{~A}$ hammered dulcimer of Iranian origin.
} 
bers. The same barriers to capital creation do not necessarily bring agents to develop the same politics of value. In the end, Afshin dropped out. Much effort, resilience as well as Germany-specific capital is required to sustain politics of value that aim at promoting diversity as familiarity and thus redefine the system of value that dominates in most German contexts.

Donya's disengagement in March 2013 marked the second rupture. In our discussion, the physician explained her withdrawal by a personal conflict with Yara which was mainly related to value politics within what may be defined as the social field formed by local Iranians. While trust based on long-term mutual acquaintance and a shared honari identification was the working principle of the group's social organization, in Donya's view, Yara was an outsider. She argued that no one knew Yara long enough to vouch for her trustworthiness. Indeed, prior to 2009, Yara had not been engaged in local Iranian social fields. She once told me: "Before 2009, I was German" (field notes, June 2013). Donya became suspicious of Yara's political allegiances, because had the impression that Yara was involved "everywhere", as she disposed, by 2012, of a large social network among locals of Iranian origin including important stakeholders.

The conflict between Donya and Yara increased as they disagreed on the values which they wanted the association to promote. Donya wanted Golestan to promote education, knowledge of Iranian (pre-Islamic) traditions, literature, acquaintance with Western high culture, democracy, human rights, and equality. In doing so, she wanted mark Golestan's adherence to the honari system of value that she defined in distinction to local "Iranian mainstream culture". However, Yara began to take over more and more responsibilities within the association. For example, Donya told me that Yara took over the organization of a party around the theme of Iranian music from the 1970s, which was initially Donya's project. After the event, Donya learnt that the DJ, an acquaintance of Yara, put on contemporary Iranian pop music, displayed the flag of the Pahlavi regime, and played the pre-revolutionary national anthem (Ey Irân). The former national anthem-a frequent element in Iranian public events in various locations of immigration (Gholami 2015, 90) — as well as the flag serve for people to distance themselves from the contemporary Iranian government and position themselves as royalists. Yet, the Iran-specific 
resources Yara put forward failed to mediate most of the values that were crucial to Donya.

These differences in taste relate to the women's diverging social origins: Yara told me that her sister is a hairdresser and I saw that her mother lives in a flat in a simple suburban three-story apartment building. Yet, she rents an apartment in the central upper middle-class neighborhood Rotherbaum, and explained me that a good economic situation was very important in her choice of a partner. Thus, through her engagement in Golestan, Yara aspired to upward social mobility from a social origin that endowed her with less inherited cultural resources than the founding members. Outraged, Donya had the impression that Yara had not only taken her place in the association, but changed Golestan's identity to one that fit her own strategies of capital creation. Not only newer, but also some of the founder members of Golestan acknowledged Yara's resources and supported her politics of value, and Donya left the association.

In sum, as people with different personal trajectories face similar barriers to creation capital in the country of residence, new alliances develop around shared strategies of capital creation. These observations confirm that "migrants actively create dynamics of validating cultural resources as capital, resulting in new forms of intra-migrant distinction" (Erel 2010, 656). For example, although Babak originally had a greater trust and affinity with Donya and Afshin, in dealing with barriers to the generation of capital in German social fields, he chose strategies of capital creation that sustained politics of value that were more similar to Yara's and those of the other new members.

Sharing the same politics of value is not a necessary condition to agreeing on collective strategies of capital creation, but certainly strengthens the group's potential for action, as we saw in the case of merchants. The conflicts considerably changed the group configuration, as Afshin and Donya's siblings followed their move and quit. Thus, as a result of the disputes, the group shifted from a space for the celebration of diversity as familiarity and the local recreation of - not exclusively Iranian-honari identities to a platform in which professionals of heterogeneous backgrounds collectively mobilize, through honari artifacts and identities, a 
neo-traditionalism which helps them to enhance their mediation of exoticism and, through assimilation, familiarity with German contexts.

\section{Collective Identifications Through Inclusion and Exclusion}

Having outlined how diverging strategies of capital creation and changing configurations within the association led to the withdrawal-the (self-)exclusion - of five founding members, what do subsequent processes of inclusion and exclusion tell us about the remaining members' collective identifications? How did they engage with systems of value that shape the social field of the German public sphere and the local Iranian social field?

Golestan's very first Stammtisch took place in an Iranian-run café in the Schanzenviertel in May 2013. I was sitting around a table with Babak, Ayda, and Said, while little by little Golestanis and prospective members arrived and introduced themselves. Everybody was of Iranian origin, most had immigrated as adults, and the common language was Persian. Then, a white-haired bearded man in his early seventies arrived.

Babak asked Ayda in Persian "Is that the guy you told me about?"

The man came towards our table and asked [in German] "You look like Persians, are you from association Golestan?"

We said "Of course", and he sat down at the far end of the table [...]. I was surprised that everybody continued to speak in Persian. The man later told me that he was a retired engineer and that he only very limited knowledge of Persian.

After a while, Babak said to Ayda "Ask the German what he wants with this calendar."

Sonja "Why don't you ask him yourself?"

Babak "I have no idea what this was about, it's you who have been in contact." They continued to talk about the man in Persian.

Finally, Babak addressed him in German and the man explained that he was looking for a Persian-speaker to help him with creating a culturally universal calendar. The man came over to us and asked Babak for help, 
but the artist evaded with an excuse and gave him the contact of an elderly acquaintance, instead. Before he left-much earlier than the rest of us - he tried to engage a group discussion in German.

He said that he took a picture of Golzar's mother, because she sat next to him at Golestan's Nowruz celebration. Half joking, half serious, Golzar commented in Persian "What do you want from my mother?" (Field notes, May 2013)

Golestanis thus made fun of and excluded the German man from group discussions. Of course, his advanced age compared to the other participants, as well as the fact that he talked lengthily about things that were not of great interest to others also contributed to his exclusion. These particularities aside, I noticed on several occasions that Golestanis made fun of people they categorized as Germans and intentionally excluded them through language barriers.

Strikingly, Golestan's public events were always bilingual or in German only, and took place in venues which testify of a high level of Western- or Germany-specific cultural resources (e.g. a Steiner school, a Museum), or in collaboration with prestigious local German cultural organizers. Thus, while access to group membership was restricted to people who spoke Persian or, at least, disposed of resources that conveyed an Iranian identification, events had the declared aim to target besides Iranians also a highly educated and well-situated German public.

Thus, Golestan's public events were geared toward the system of value of the German public sphere: they tried to get acknowledgment for their Iran-specific resources as capital for conveying exoticism, and yet fulfill the expectation of assimilation and familiarity with German cultural elements. For this purpose, they needed a German public. Yet, within the association, Golestanis created a different system of value, where resources that mediated familiarity with Iranian cultural elements, such as language, cultural references, and humor, were key. Consequently, people who, like the elderly German man, lacked these resources, were unable to create capital. In a similar way, Çetin Çelik (2015) finds "reactive ethnicity", that is, forwarding resources related to the country of origin in order to exclude Germans, to be a common response to the experience of 
exclusion among working class male youth of Turkish descent in Germany. In our case, another reason for the exclusion of Germans is that their incorporation would impede on the Golestanis' collective staging of Iranianness in German social fields. Thus, while Golestanis created an internal system of value that, as it seems here, opposes the one that dominates the social field of the German public sphere, they contradicted this counterpublic in (at least apparently) complying to the hegemonic evaluations in their public events.

A month later, I got to know Navid, a stout 34-year-old, with a round face, big, black-framed glasses and brown hair at shoulder length, at an exhibition which featured some of his posters. He told me that his father was a factory manager from Iran and that he was raised partly in the southern Iranian city of Shiraz, partly in the USA, and came to Germany as a student three years before. One of his grandmothers, however, was a Native American. It struck me that he has a rather English than Persian accent in German. When speaking Persian, he frequently interweaves English words. When I told him about Golestan, its artist identity, and their monthly meetings in a bar in the Schanzenviertel, reflecting identifications with local alternative and artistic subculture, he was surprised: "I never thought Iranians would meet there" (field notes, July 2013). Adding "I might work for them as a graphic designer", he accepted my proposition to join the next Stammtisch.

When Navid and I arrived at the bar, seven people were sitting around a table: the official members Babak, Yara, Farzan, and Golzar, as well as their friends Karim, Kaspar, and Shahram. When I introduced Navid, someone asked for his family name. After hearing the answer, Babak inquired "Are you related to the famous writer?" Navid confirmed that he was. We took a seat, and the group decided to make a round of introductions. Yara explained that Kaspar, a Munich-grown 24-year-old law student and child of a binational German-Iranian couple, does not speak Persian. She translated for him during the meeting. When it was Navid's turn,

he began to explain [in Persian] that he had recently finished his master, and that he wants to start a $\mathrm{PhD}$ in the following months. In Iran, he had studied at Tehran University (dâneshgâh tehrân). He said that he was half-American. 
Someone asked "Did you come here directly?"

Navid "No, I lived in the US and in London before."

Someone "Where about in the US?"

Navid "In New York, Ohio, and Louisiana. Because of my father's jobs."

Babak "What subject did you do your Master's in?"

Navid "Graphic design."

Yara "So you're an artist (honarmand)? Welcome! We already have some artists."

Navid "Why? Who else is an artist?"

Yara "We have Sadegh but he isn't here today, and Babak." (Field notes, July 2013)

The Golestanis' evaluation of Navid's resources gives more detailed insights into the internal system of value which their collective identifications relied on after the conflict. First, inquiring about his family namea practice I frequently witnessed in Iran as well as among people of Iranian origin living in Germany-allowed the members to identify him as a relative of a renowned writer and as a member of an urban upper middleclass family.

Second, as they ask him about his migratory trajectory, they indirectly evaluate the volume and distribution of his Western- and Germanyspecific resources. The apprehension of this evaluation is probably the reason why Navid spoke Persian even though he knew that Kaspar did not understand the language- - he avoided exposing his accent in German. Indeed, I repeatedly noticed that Golestanis sought distinction from Iranians who they found lacking Germany-specific resources. For example, Babak and Yara frequently imitated the Persian accent in German language, ${ }^{15}$ which gave rise to much laughter among their public.

Third, a criterion on which Navid was evaluated but which does not appear in the vignette was his age. A friend and social scientist explained me that his father was a Golestani by exception: the board had told him that it does not want people of his age in the association. Research in other national contexts shows that the objectives of Iranian associations change with the age of its members (Van den Bos and Achbari 2007;

\footnotetext{
${ }^{15}$ For native Persian speakers, combinations of different consecutive consonants in German are difficult to pronounce if they are not preceded by a vowel. This is why they often add a vowel, saying, for example, Estrasse instead of Strasse (street).
} 
Ghorashi and Boersma 2009; Maghbouleh 2013). This observation needs to be understood in the context of constructed generational divides relative to political, social, and economic conditions in Iran: those who experienced the Islamic revolution in Iran as young adults are called the "first generation". Correspondingly, the category "second generation", with which Babak identifies, refers to people who were children at the time of the revolution, and whose youth was shaped by the new political order and the Iran-Iraq war. Finally, people who claim to belong to the "third generation", or the "burnt generation" (nasl-e sukhte), stress that they never knew any other political order than that of the Islamic Republic (Khosravi 2008, 4f.). Golestan's aim, as declared by Yara in the talk show and on videos published on the association's website, is to address the younger generations, regardless of whether they grew up in Germany or in Iran, supposedly in order to bridge political differences that caused divisions among their parents.

Finally, only when Navid revealed that he was an artist did Yara explicitly welcome him to the group. When we left, Yara asked Navid for his email address and when I met him two weeks later, he told me that she had proposed him to take over a mandate for a friend. In the valorization of an artist background, the interests of different members conflate. First, some of the founding members, like Babak, still aim at establishing professional networks which sustains the founding members' tentative to build Golestan's identity on the honari imaginary. Plus, adherence to the honari imaginary is a way for people with modest inherited resources, like Yara, to claim belonging to the intelligentsia and enact upward social mobility. Second, the system of value of the honari imaginary has the advantage of sharing some of the key values prevalent in German social fields, that is, democracy, equality, and human rights, but also Western high culture. For example, the female Golestanis made up less and dressed more casually than most local women of Iranian origin. In doing so, they showed adherence to the value of gender equality that is important both in honari contexts and in German society, where women tend to value rather practical dress styles. People in Hamburg, in particular, are known for the Hamburger Understatement, that is, privileging modesty to ostentation - a value presumably dating back to the time of the Hanse (Knödler 
2014). This trend is even stronger among people who consider themselves to be a part of the artist and alternative subcultures. Third, and relatedly, the internal system of value shifted from the importance of transnational political engagement toward staging exoticism in German contexts (Ghorashi 2004; Kelly 2011; Maghbouleh 2013; Gholami 2015). Significantly, out of six bands in FusIran's lineup, only one was actually based in Iran and it can perform legally.

Thus, Navid's resources mediated values that were key in the social field of the association, namely an Iranian identification, an upper middle-class background, education, youth, professionalism, adherence to the honari imaginary, and familiarity with Western cultural contexts. On this basis, Golestanis wanted to include Navid in the group. However, he did not want to become a member of Golestan and spent most of the Stammtisch talking with Karim and Kaspar, who are not officially members of Golestan, and who nourish strong German identifications.

These two instances of boundary-making show that, while Golestan's internal system of value is distinct from the one that shapes the German public sphere, the latter shapes the former to the extent that, here too, Germany-specific resources that mediate familiarity are key for capital creation. Moreover, as the honari imaginary is historically shaped by systems of value which highlight Western cultural elements, the systems of value within the transnational social field of Iranian artists and arty people as well as those prevalent in German society overlap. Thus, while Golestan's internal system of value opposes the one that dominates in the German public sphere in valuing certain Iran-specific resources, it concurs with it in highlighting the importance of Germany-specific resources. The pervasiveness of systems of value in which familiarity with the West is central across diverse local and transnational social fields tends to limit migrants' possibilities to agree on collective politics of value.

Yet, even if Golestanis' room for creative action is restricted for these reasons, their politics of value may be very subtle, as we will see in the way they are staging Iranianness in a second public media representation, almost two years after Afshin and Yara's participation in the talk show. 


\section{Staging "Iranianness in Hamburg"}

In April 2014, a film team producing short documentaries for a German public channel, making diverting portrays of migrant "communities" living in different German cities, contacted Golestan to propose the participation in a new production. The members agreed and Golzar invited the film team, as well as 12 Golestanis and friends, 9 men and 3 women, for dinner at her place. When I arrived, I found the Golestanis sitting on chairs and sofas along the walls of the living room-a spatial configuration that reminded me of receptions (mehmunis) I experienced in Iran in rather traditional contexts - with a blond and jocular German journalist in their midst. A cameraman, a sound technician, and a program manager, a women in her late twenties who was herself of Iranian origin, stood in the center of the room, filming. After everybody presented himself, the journalist asked questions like

What do you talk about when you're among yourselves?

or,

What do you say about Germany?

or,

Don't you think Germans are cold and unfriendly? As a Southerner, I personally find Northerners cold, too.

Although we had just presented ourselves and our heterogeneous trajectories, the journalist defined us as Iranians, and not as Germans. When talk came to the code of politeness (ta'ârof), we explained at length its particularities. In showing a critical distance from an element central to sociability in Iranian contexts, we displayed important Germany-specific resources and collectively claimed their recognition as a capital. Golzar had cooked an Iranian dinner. While the Golestanis and the journalist remained in the living room, holding their plates in their hands, the film team was eating apart from us in the kitchen. I sat next to Babak, when 
he suggested, in Persian, "Guys, let's all stand up and do a quick dance. On three!"

Golzar "They will take us for fools!"

Babak "That's the whole point!"

Golzar "Where do we get the music from?"

Babak "We do it ourselves."

Golzar "But I can't do that!"

The program manager, who understood Persian, alerted her colleagues "Film! They're going to dance!"

The Golestanis wanted to dance although the surprise was spoiled. Kian stood up and acted as if he got upset by Golzar "Pedareman-o dar âvordi [You go on my nervs]! You stop arguing now!"

We counted to three, then stood up, clapping hands and half-dancing. Golzar danced alone in our midst [Image 4.3].

After two minutes Kian said "And now we sit down and do as if nothing had happened." That was what we did. (Field notes, April 2014)

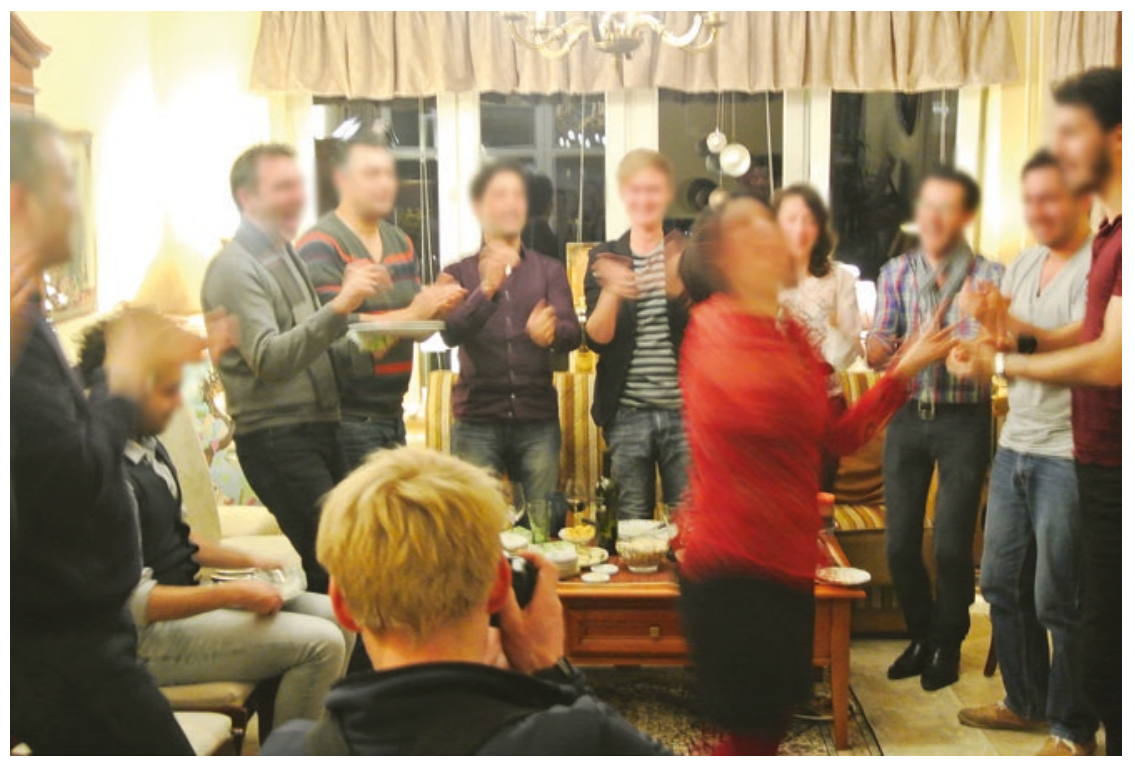

Image 4.3 Golzar dances in front of German journalists in her living room. (April 2014, picture taken by a member of the film crew with the author's camera, anonymized) 
What the film team had expected — despite the program manager being of Iranian origin - was the display of collective cultural difference. In the initial discussion, however, this difference was mediated, because we showed that we dispose of important Germany-specific resources. However, unconsciously or consciously, the Golestanis understood that in order to be interesting for the film team, there was a need to stage Iranian identifications-in a way, a need for self-exoticization. Strikingly, however, we staged the difference in a way that its performative character became obvious. Ultimately, in a very subtle way, we thus ridiculed the Germans' interest in the exotic, as a sort of incomplete and disavowed critique (Li 2019). The producer may have understood these discreet politics of value, because the final documentation did not contain any of the scenes shot during that evening.

In the face of the difficulty to their having Germany-specific resources valorized because of the Golestanis' categorization as culturally different, appropriating the category by staging secular and apolitical Iranian identifications became increasingly important to the association's activities. Cattacin and Domenig $(2014,724)$ stated:

Having and defending something like a culture thus becomes a way to tell others that they do not possess a monopoly on culture, which turns culture into a topic of sameness, and no longer of difference. The lack of recognition is, therefore, the reason why associations invent culture and invest in the marketing of a specific cultural image.

Golestanis thereby had a critical distance toward their self-exoticization and tried indirectly to act upon the system of value prevailing in the German public sphere. The context of associations is particularly favorable for claiming recognition of Iran-specific resources as capital. However, the fact of complying, even if in incomplete ways, with the dominant system of value tends to, if not perpetuate, at least prolong the barriers to capital creation that derive from migrants' perceived lack of familiarity in combination with their construction as racial Others.

\section{Epilogue}

In our Skype interview in November 2015, Donya told me that after much consideration, she went to the concert of one of her favorite bands 
from Iran, Pallett, organized by Golestan in Hamburg in the fall of 2015. "There were not even three likeable faces", she commented. When I asked her what she meant by that, she said "They were all highly made up." Moreover, she explained me that when she recently told Babak that she considered rejoining Golestan, he replied "There is nothing for you to find there anymore, people are all the same, there is no diversity" (field notes, November 2015). In spring 2014, Sadegh told me that he would prefer Golestanis to be older and more settled.

Sonja "But many are also artists."

Sadegh "Yes, but that's not necessarily good."

Sonja "Why not?" I thought that was what he wanted.

Sadegh "They expect something that does not correspond to reality. Many will leave again. Several already left. Some people only participate because they find it useful. At the moment I help Zian, and I will help Parham when the time has come. But I would have helped them even if they were not members of Golestan." (Field notes, April 2014)

Their statements confirm a development I traced in this chapter: dynamics taking place within Golestan take it ever further away from its initial left-wing artist and honari identifications in order to provide images that speak to a larger public_-both German and Iranian.

While the previous chapter was about the way migrants' collective identifications develop as a collective engagement with changing systems of values in different social fields, in this chapter, my aim was to show, how such a collectivity develops from an in-group perspective. How do processes of evaluation within an association relate to systems of value that prevail in the German public sphere, the local Iranian social field and the transnational social field of Iranians identifying as honari?

German approaches to immigration rely on a paradox: they require assimilation to and familiarity with what is defined as German, but the racialization of migrants simultaneously makes this objective barely attainable, as being German and having other cultural identifications tends to be seen as mutually exclusive. In this context, associations provide spaces in which migrants may find ways to contest or circumvent barriers to capital creation they meet in the society of residence.

Collective identifications may be part of politics of value that engage with hegemonic valuations through the formation of so-called counter- 
publics (Nicholls and Uitermark 2016). They emerge between people whose strategies of capital creation share the same objective in the same social field at a given time. I showed that through internal boundarymaking, Golestanis created an internal system of value. However, their system of value only partly opposes the one that prevails in the German public sphere. Both systems of value as well as the one that sustains the honari imaginary intersect in granting familiarity with Germany or the West a key position. The pervasiveness of the valorization of Westernspecific resources across local and transnational social fields and migrants' unequal individual resources pose important obstacles to their collective politics of value. I showed in Chap. 3 that migrants' politics of value do have the power to redefine the value of their resources, but an important key to their success is long-term engagement and collective action.

Confirming related ethnographies (Graham and Khosravi 1997; Sanadjian 2000; Ghorashi 2004), I showed that Golestanis tried to stage Iranian identifications alternative to the image of the Islamic Republic. After members who promoted non-ethnic diversity as a value connected to familiarity left the association, the collective strategies of capital creation which the remaining Golestanis agreed upon are part of politics of value that aim at enhancing Iran-specific resources' exoticism and mediating assimilation and familiarity through Germany-specific resources. This may temporarily help to overcome certain barriers to capital creation. However, it barely acts on the cause of the barrier, that is, prevailing systems of value. An active contestation of ethnic and national categorizations requires more Germany-specific resources, and may be more laborious and protracted, but ultimately more efficient in acting upon systems of value that produce and sustain structural racism.

In this chapter, I observed that people may implement incompatible or even competitive strategies of capital creation to engage with the systems of value that highlight familiarity with the West. In the next chapter, I interrogate its causes and effects through a micro-perspective, examining boundary-making between three colleagues and friends working in the film business. 


\section{References}

Abrahamian, Ervand. 2008. A History of Modern Iran. Cambridge: Cambridge University Press.

Alexanian, Janet A. 2011. Eyewitness Accounts and Political Claims: Transnational Responses to the 2009 Postelection Protests in Iran. Comparative Studies of South Asia, Africa and the Middle East 31 (2): 425-442. https://doi.org/10.1215/1089201X-1264334.

Amelina, Anna, and Thomas Faist. 2008. Turkish Migrant Associations in Germany: Between Integration Pressure and Transnational Linkages. Revue européenne des migrations internationales [online] 24 (2). http://remi. revues.org/4542

Bail, Christopher A. 2008. The Configuration of Symbolic Boundaries Against Immigrants in Europe. American Sociological Review 73 (1): 37-59.

Bourdieu, Pierre. 1979. La distinction. Critique sociale du jugement. Paris: Editions de Minuit.

Brubaker, Rogers, and Frederick Cooper. 2000. Beyond 'Identity'. Theory and Society 29 (1): 1-47. https://doi.org/10.1023/A:1007068714468.

Bührmann, Andrea D., and Karen Schönwälder. 2017. Public Organisations and Diversity: Approaches to an Under-Researched Topic. Journal of Ethnic and Migration Studies 43 (10): 1635-1643. https://doi.org/10.1080/13691 83X.2017.1293588.

Bundesministerium der Justiz und für Verbraucherschutz. 2015. Staatsangehörigkeitsgesetz (StAG). http://www.gesetze-im-internet.de/bundesrecht/ rustag/gesamt.pdf

Cattacin, Sandro, and Dagmar Domenig. 2014. Why Do Transnationally Mobile People Volunteer? Insights from a Swiss Case Study. VOLUNTAS: International Journal of Voluntary and Nonprofit Organizations 25: 707-729.

Cederberg, Maja. 2015. Embodied Cultural Capital and the Study of Ethnic Inequalities. In Migrant Capital: Networks, Identities and Strategies, Migration, Diasporas and Citizenship, ed. Louise Ryan, Umut Erel, and Alessio D’Angelo, 33-47. Hampshire/New York: Palgrave Macmillan.

Çelik, Çetin. 2015. 'Having a German Passport Will Not Make Me German': Reactive Ethnicity and Oppositional Identity among Disadvantaged Male Turkish Second-Generation Youth in Germany. Ethnic and Racial Studies 38 (9): 1646-1662.

. 2017. Disadvantaged, But Morally Superior: Ethnic Boundary Making Strategies of Second-Generation Male Turkish Immigrant Youth in Germany. Identities 25: 1-19. https://doi.org/10.1080/1070289X.2017.1305218. 
Ehrkamp, Patricia. 2006. 'We Turks Are No Germans': Assimilation Discourses and the Dialectical Construction of Identities in Germany. Environment and Planning A 38 (9): 1673-1692. https://doi.org/10.1068/a38148.

El-Tayeb, Fatima. 2004. Kanak Attak! Hiphop und (Anti-)Identitätsmodelle der 'Zweiten Generation'. In Jenseits des Paradigmas kultureller Differenz: Neue Perspektiven auf Einwanderer aus der Türkei, ed. Martin Sökefeld, 95-110. Bielefeld: transcript Verlag.

- 2016. Undeutsch: Die Konstruktion des Anderen in der postmigrantischen Gesellschaft. Bielefeld: transcript Verlag.

Emami, K. 1986. Art in Iran Xi. Post-Qajar. Encyclopaedia Iranica II (6): 640-646. Erel, Umut. 2010. Migrating Cultural Capital: Bourdieu in Migration Studies. Sociology 44 (4): 642-660. https://doi.org/10.1177/0038038510369363.

Fleming, Crystal, Michèle Lamont, and Jessica Welburn. 2012. African Americans Respond to Stigmatization: The Meanings and Salience of Confronting, Deflecting Conflict, Educating the Ignorant and 'Managing the Self'. Ethnic and Racial Studies 35 (3): 400-417.

Gaserow, Vera. 1995. Denkwürdige Anregung. Die Zeit, May 19. http://www. zeit.de/1995/19/Denkwuerdige_Anregung/komplettansicht

Gholami, Reza. 2015. Secularism and Identity: Non-Islamiosity in the Iranian Diaspora, Studies in Migration and Diaspora. Surrey/Burlington: Ashgate Publishing Limited.

Ghorashi, Halleh. 2004. How Dual Is Transnational Identity? A Debate on Dual Positioning of Diaspora Organizations. Culture and Organization 10 (4): 329-340. https://doi.org/10.1080/1475955042000313768.

Ghorashi, Halleh, and Kees Boersma. 2009. The 'Iranian Diaspora' and the New Media: From Political Action to Humanitarian Help. Development and Change 40 (4): 667-691. https://doi.org/10.1111/j.1467-7660.2009.01567.x. Goldberg, David Theo. 2006. Racial Europeanization. Ethnic and Racial Studies 29 (2): 331-364. https://doi.org/10.1080/01419870500465611.

Graham, Mark, and Shahram Khosravi. 1997. Home Is Where You Make It:

Repatriation and Diaspora Culture among Iranians in Sweden. Journal of Refugee Studies 10 (2): 115-133.

Grigor, Talinn. 2012. Return of the Avant-Garde to the Streets of Tehran. In Iranian Nationalism Revisited, ed. Kamran Aghai and Afshin Marashi, 235-254. Austin: University of Texas Press.

Gruner, Sabine. 2010. 'The Others Don't Want ...'. Small-Scale Segregation: Hegemonic Public Discourses and Racial Boundaries in German Neighbourhoods. Journal of Ethnic and Migration Studies 36 (2): 275-292. https://doi.org/10.1080/13691830903387402. 
Hall, Suzanne M. 2017. Mooring 'Super-Diversity' to a Brutal Migration Milieu. Ethnic and Racial Studies 40 (9): 1562-1573. https://doi.org/10.108 0/01419870.2017.1300296.

Halter, Marilyn. 2007. Shopping for Identity: The Marketing of Ethnicity. New York: Schocken Books.

Kelly, Melissa. 2011. Transnational Diasporic Identities: Unity and Diversity in Iranian-Focused Organizations in Sweden. Comparative Studies of South Asia, Africa and the Middle East 31 (2): 443-454.

Kelly, Philip, and Tom Lusis. 2006. Migration and the Transnational Habitus: Evidence from Canada and the Philippines. Environment and Planning A 38 (5): 831-847.

Keshmirshekan, Hamid. 2010. The Question of Identity Vis-à-Vis Exoticism in Contemporary Iranian Art. Iranian Studies 43 (4): 489-512. https://doi.org/ 10.1080/00210862.2010.495566.

Khosravi, Shahram. 2008. Young and Defiant in Tehran. Philadelphia: University of Pennsylvania Press.

Knödler, Gernot. 2014. Reeder Schües über das Hanseatische: 'Das wäre angeberisch.' TAZ, July 2. http://www.taz.de/!5049021/

Li, Tania Murray. 2019. Politics, Interrupted. Anthropological Theory 19 (1): 29-53. https://doi.org/10.1177/1463499618785330.

Maghbouleh, Neda. 2013. The Ta'arof Tournament: Cultural Performances of Ethno-National Identity at a Diasporic Summer Camp. Ethnic and Racial Studies 36 (5): 818-837. https://doi.org/10.1080/01419870.2011.648649.

Malek, Amy. 2011. Public Performances of Identity Negotiation in the Iranian Diaspora: The New York Persian Day Parade. Comparative Studies of South Asia, Africa and the Middle East 31 (2): 388-410. https://doi.org/10.1215/1 $089201 X-1264316$.

Mandel, Ruth. 2008. Cosmopolitan Anxieties: Turkish Challenges to Citizenship and Belonging in Germany. Durham/London: Duke University Press.

Moya, Jose C. 2005. Immigrants and Associations: A Global and Historical Perspective. Journal of Ethnic and Migration Studies 31 (5): 833-864. https:// doi.org/10.1080/13691830500178147.

Naegler, Laura. 2012. Gentrification and Resistance: Cultural Criminology, Control, and the Commodification of Urban Protest in Hamburg, Hamburger Studien Zur Kriminologie Und Kriminalpolitik. Münster: Lit Verlag.

Nicholls, Walter J., and Justus Uitermark. 2016. Migrant Cities: Place, Power, and Voice in the Era of Super Diversity. Journal of Ethnic and Migration Studies 42 (6): 877-892. https://doi.org/10.1080/1369183X.2015.1126088. 
Ong, Aihwa. 1999. Flexible Citizenship: The Cultural Logics of Transnationality. Durham: Duke University Press.

Prashizky, Anna, and Larissa Remennick. 2015. Cultural Capital in Migration: Fishka Association of Young Russian-Speaking Adults in Tel-Aviv, Israel. Journal of Intercultural Studies 36 (1): 17-34. https://doi.org/10.1080/07256 868.2014.990364.

Sadjed, Ariane. 2012. "Shopping for Freedom" in Der Islamischen Republik: Widerstand Und Konformismus Im Konsumverhalten Der Iranischen Mittelschicht, Kultur Und Soziale Praxis. Bielefeld: transcript Verlag.

Sanadjian, Manuchehr. 2000. 'They Got Game’ Asylum Rights and Marginality in the Diaspora: The World-Cup and Iranian Exiles. Social Identities 6 (2): 143-164. https://doi.org/10.1080/13504630050032044.

Schiller, Maria. 2016. European Cities, Municipal Organizations and Diversity: The New Politics of Difference, Global Diversities. Basingstoke: Palgrave Macmillan.

Shooman, Yasemin. 2014. “... Weil ihre Kultur so ist”: Narrative des antimuslimischen Rassismus, Kultur und soziale Praxis. Bielefeld: transcript Verlag.

Sökefeld, Martin. 2004. Das Paradigma kultureller Differenz: Zur Forschung und Diskussion über Migranten aus der Türkei in Deutschland. In Jenseits des Paradigmas kultureller Differenz: Neue Perspektiven auf Einwanderer aus der Türkei, ed. Martin Sökefeld, 9-33. Bielefeld: transcript Verlag.

Spellman, Kathryn. 2004. Religion and Nation: Iranian Local and Transnational Networks in Britain. Oxford: Berghahn Books.

Strasser, Sabine. 2006. “Die dritte Türkenbelagerung?” Bewegte Zugehörigkeiten, strategische Repräsentationen und die Bekämpfung von Ungleichheiten. Kurswechsel. Zeitschrift für Gesellschafts-, Wirtschafts- Und Umweltpolitische Alternativen 2: 88-98.

- 2008. Europe's Other. European Societies 10 (2): 177-195. https://doi. org/10.1080/14616690701835261.

Van den Bos, Matthijs, and Wahideh Achbari. 2007. Cultural Migration: Networks of Iranian Organizations in the Netherlands. Migration Letters 4 (2): 171-181.

Weiss, Anja. 2001. Rassismus als symbolisch vermittelte Dimension sozialer Ungerechtigkeit. In Klasse und Klassifikation. Die symbolische Dimension sozialer Ungerechtigkeit, ed. Anja Weiss, Cornelia Koppetsch, Albert Scharenberg, and Oliver Schmidtke, 79-108. Opladen: Westdeutscher Verlag. 
Open Access This chapter is licensed under the terms of the Creative Commons Attribution 4.0 International License (http://creativecommons.org/licenses/ by/4.0/), which permits use, sharing, adaptation, distribution and reproduction in any medium or format, as long as you give appropriate credit to the original author(s) and the source, provide a link to the Creative Commons licence and indicate if changes were made.

The images or other third party material in this chapter are included in the chapter's Creative Commons licence, unless indicated otherwise in a credit line to the material. If material is not included in the chapter's Creative Commons licence and your intended use is not permitted by statutory regulation or exceeds the permitted use, you will need to obtain permission directly from the copyright holder.

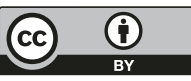




\section{The Overlapping Uncertainties of Film Professionals}

On a sunny day in July 2015, I passed a grey-haired man in his late sixties, pushing a buggy with an about three-year-old boy in the center of Geneva. Overhearing him teaching the child Persian language, I became intrigued. The man must have noticed my interest because he greeted me in English. My response in Persian initiated a discussion: loquaciously, he began to explain that he lives in Tehran, and that he and his wife came to Geneva for a month to see their two daughters. Without me asking for details, he said "My first daughter studied business administration at [some university in Switzerland] and her husband is a lawyer. My second daughter studies medicine. What do you do?" Not in the mood for long explanations, I limited myself to telling him that I was a student. He continued "I work for Iran Air at Tehran's Imam Khomeini Airport. In case you have any issue when you are there, just ask for me." Then, he told me his name. (Field notes, July 2015)

Education and Western-specific resources, independence, but also cooperation are the values that emerge through this short dialogue. The man put forward his own and his daughters' professional achievements, calling for my recognition of their resources-in particular those acquired in Switzerland - as capital and invoked comparison by asking me to do the 
same. Would he have done so if I had not revealed my Iranian identifications? I think that it is our common Iranian origin that led the man to vaunt in particular those resources created in Western countries and to suggest some kind of cooperation.

Extant research underlines that, for many migrants, education and professional success is a way through which they try to overcome racial barriers to capital creation (Ong 1996; El-Mafaalani 2012; Schneider and Lang 2014; Olwig and Valentin 2015). However, as their new location-specific resources mediate independence, that may contradict the value of cooperation in relations with fellow migrants (Portes and Landolt 1996). In Iran itself, as well, people hail personal accomplishment and competition about professional success (Adelkhah 1998, 199-247; Bromberger 2003, 2009; Sadjed 2012, 90-94), whereby the display of resources that mediate familiarity with Western cultural contexts plays an important role (Mahdavi 2007; Khosravi 2008; Sadjed 2012). It is thus no coincidence that the grid the man used for promoting his own resources and evaluating mine reminded me of the way the film professionals Hushang, Zian, and Milad talked about their own and each other's work. What does the boundary work of migrant professionals who are engaged in several of the same social fields say about the way their strategies of capital creation interact with competing and contradictory systems of value?

The interplay between internal boundary-making and transnational capital creation, I asserted, is motivated by individual and collective politics that engage with systems of value prevalent in local and transnational social fields. So far, the case studies of Iranian carpet merchants and members of association Golestan respectively showed how migrants' collective identifications could bring divergent systems of value to acknowledge the same resources in different social fields, and how intersecting systems of value largely determine migrants' collective identifications. Having thus drawn the different ways systems of value interact on migrants' capital creation across social fields, I change the perspective and use the boundary approach in order to trace the effect of these dynamics on the everyday negotiation of internal diversity.

In this chapter, I take up the intra-relational perspective from Chap. 2 to explain what happens when people who consider themselves friends 
and colleagues follow competitive strategies of capital creation within and across local and transnational social fields. To this end, I examine the interactions between three film professionals of Iranian origin-a technician in a precarious occupational situation, an ambitious student of filmmaking, and a newly exiled director-in the context of their professional trajectories. Hushang, Zian, and Milad live in Hamburg and are all engaged in the transnational Iranian and the German social fields of film professionals, as well as in the local Iranian social field. Tehran-grown in middle-class families, they have the same gender and age-they are all in their thirties. As we shall see in the following, what distinguishes the film professionals is the amount and volume of their professional resources and the place of their creation (Germany or Iran), deriving from different professional and migratory trajectories. The analysis suggests that, while the men's success in generating capital in the society of residence strongly shapes their possibilities to do so in the local and transnational Iranian social fields, there is also a great individual variation in the way they navigate these systems of value and their interrelation, depending on their age, their professional position, and in how far their past experiences of exclusion influence their contemporary behavior.

\section{The Social Fields of Film Professionals}

Much about the dynamics that shape the social fields of film professionals will become clear in the discussion of Hushang's, Zian's, and Milad's trajectories. However, at this point, I point out two things that form the context of the following analysis.

First, the working conditions in the film business are characterized by a high level of uncertainty-although to different degrees depending on individual positions in professional hierarchies. As I learned through my contact with film professionals, this derives from several sources: first, filmmaking mostly takes place in specific time-restricted projects, for which a team of professionals is constituted and works together intensively, only to be dissolved after the task is finalized (see also Apitzsch 2010, 410ff.). Different work units are thereby highly interdependent, increasing thus, as we shall see below, the social embeddedness of 
economic action (Granovetter 1985). Plus, the team has to be efficient quickly, despite long working hours and often while being geographically mobile. ${ }^{1}$ Second, as Hushang explained to me, fixed work contracts are very rare. Most of the time, people get employed-for independent "lowbudget" or "no-budget" projects also paid-only for the time of a specific project. Third, just as in the carpet trade, the film business has relatively low levels of professionalization. In other words, there are no standardized educational curricula, access to the job market is not based on formal qualification, and there is a lack of institutional supervision. Informal, experience-based learning and access through auxiliary jobs prevails (Apitzsch 2010, 413; Ortner 2013). In a nutshell, with little international variation, working in the film business demands very high flexibility and independence deriving from the unstable demand of film productions, but also, somewhat conflictingly, alliance and cooperation.

Second, for the following analysis, it is important to note that, through their engagement in the transnational social fields of Iranian film professionals, Hushang, Zian, and Milad are indirectly acquainted to or in direct contact with numerous film professionals of Iranian origin, be they actors, technicians, camera operators, directors, or producers, living in Germany, in Iran, or in any other country.

Sonja "Did you watch the movie 'Women without men' [Neshat 2009]? Probably, didn't you?"

Hushang "Yes."

Sonja "How did you like it?"

Hushang "Mmm, so-so. The story was good but the implementation wasn't. Did you notice that two of the actors also figured in my documentary?"

Sonja "Really? No. Which ones?"

Hushang "One of them was "the General". He was supposed to be the foil of the protagonist [...]. And then Zahra. ${ }^{2}$ Originally, she was my assistant but she appeared once in the discussion round."

Sonja "Ah ok!" It seemed important to him to have these two actors who acted in internationally screened movies participate.

\footnotetext{
${ }^{1}$ For an ethnography of independent film sets, see Sherry B. Ortner (2013, 213-27).

${ }^{2}$ Pseudonym.
} 
Hushang "They shot the movie [Women without men] in Morocco. A friend is now shooting a movie at the same location." (Field notes, April 2013)

We can see that the transnational social field of Iranian film professionals has specific geographical hubs. Different places in Morocco, for example, serve as sets for the growing number of movies shot outside Iran to prevent government censorship. ${ }^{3}$ For different reasons, Hamburg is another hub for Iranian film professionals: it has three colleges and universities that offer technical and artistic curricula in the field, ${ }^{4}$ and its international film festival regularly features Iranian movies for many years now. Two local actors identifying as Iranians, Arash Marandi and Ramin Yazdani, work in international film productions. Besides numerous German-run businesses, the presence of Sina, a director of international renown, and the Germany-wide successful film-producing company of Hessam $^{5}$ certainly are another contribution.

\section{Hushang, Between Contesting and Conforming to Assimilation}

Hushang is a 39-year-old man, single when I first met him, and always dressed with care. His spacious apartment, decorated with artifacts he brought back from his international travels, is situated in a middle-class neighborhood close to the port of Hamburg. Hushang, who is a friend of the artist Babak (see Chap. 4), loves to learn about history and society. He likes both sarcastic jokes and good coffee. This is why we often met in his preferred café-bar in the central, formerly alternative, now yuppie Schanzenviertel.

\footnotetext{
${ }^{3}$ For studies on Iranian cinema, see Hamid Naficy (for instance 2012).

${ }^{4}$ These include the semi-private Hamburg Media School, the public HfBK, the University of Applied Sciences (Hochschule für angewandte Wissenschaften, in short HAW).

${ }^{5}$ To my knowledge, the first filmmaker of Iranian origin who lived in Germany was Sohrab Shahid Saless, who settled in Berlin in 1974, fleeing persecution by the Pahlavi government. He made numerous successful feature movies in German, before he moved on to the USA in 1992 (Langford 2016).
} 
Hushang told me that his father was a gun seller and landowner from Mazanderan, a northern Iranian province, but he himself grew up in Tehran. He came to Hamburg in 1992, when he was 18 years old, together with his older brother. Only much later, I learnt that he did not come as a student but sought asylum-I will come back to this. Most of his remaining four siblings also live outside Iran. His elderly parents, however, still live in one of Tehran's northern high-end districts, which is one of the main reasons why Hushang goes there regularly.

As his Iranian high school diploma was not recognized in Germany, ${ }^{6}$ after obtaining asylum, he had to do a one-year foundation course (Studienkolleg) before being able to enter college. He graduated from the Hamburg University of Applied Sciences (HAW) in the early 2000s. Thus, having spent half of his life in Iran, and the other half in Germany, Hushang acquired significant cultural resources that can be considered as Germany-specific, that is, a college diploma and German citizenship, and he speaks accent-free German.

Today, Hushang is a freelance light and sound technician and explicitly claims focusing on capital creation in the German job market, that is, in the German social field of film professionals. Indeed, during the time I was in Hamburg for fieldwork, he accepted more mandates from German then from Iranian employers. His missions often involve traveling within Germany or to other European countries. Several times, he mentioned that the high level of uncertainty inherent in living from short-term mandates is not always easy to bear. However, he prefers time flexibility to financial stability, and therefore refuses full-time employment. He values his independence as a freelancer.

Notwithstanding these career choices, Hushang frequently talks about difficulties to generate capital in the German professional social field. For example, during one of our first meetings in spring 2013, when we took a walk through the Schanzenviertel, he said that some classmates who had done worse in school than him now have a more successful career. He explained this perceived disadvantage by his categorization as Iranian, saying

\footnotetext{
${ }^{6}$ This is the case for most degrees obtained in non-Western countries (Nohl et al. 2014).
} 
Compared to German colleagues I have to do double: to each new employer I do not only have to prove my qualification, but I also have to show that I am not as they expect Iranians to be like. (Field notes, April 2013)

In particular, he has to prove accuracy and punctuality—values employers would take for granted in German competitors. In other words, just like Yara in Chap. 4, he reported that his assumed cultural and perceived racial difference impeded on his capital creation. Hence, in his professional social field, accuracy and punctuality are subordinated to the key value of familiarity with German cultural elements. In Chap. 4, I showed that the assimilationist approach to immigration leaves little space for culturally pluralistic identifications, the perception of cultural or racial difference often leads to the exclusion even of those migrants who have with significant Germany-specific resources (see also Sadeghi 2018). Hushang's gender certainly adds further disadvantages. According to Aihwa Ong (1996), in the USA the trajectories of migrant men, more than those of women, are measured against neoliberal ideals of selfsufficiency and efficiency. In addition, people tend to associate men from predominantly Muslim countries with patriarchal domination, which fails to mediate the value of equality and thus reinforces barriers to their capital creation (Khosravi 1999; Çelik 2015). Based on these experiences, Hushang developed a certain reluctance and cynicism in his engagement in the German social fields of film professionals.

However, contrary to his claims, Hushang is not simply passively being Othered. Indeed, earlier in the same discussion, he mentioned that his relations with German colleagues never go beyond a certain level of acquaintance. For example, he criticized that German film professionals have a sober attitude at work, and restrain from enjoyable leisure activities, even when abroad. His tendency to seek distinction from German colleagues is reflected in a picture Hushang took during a shooting in the south of France and posted on his Facebook account. It shows three pairs of men's feet leisurely positioned on a low table-he and his colleagues enjoy a Feierabendbier (literally: "after-work-beer")—a ritual frequent in German work contexts. Hushang exposes his blue plastic slippers (dampâi), which look as if he brought them from Iran. In the Iranian urban middle class, such slippers are worn mainly at home or during free 
time. In this photo, Hushang underlines a laid-back ethos that contrasts with his German colleagues' street shoes. In short, in wearing these slippers and, more importantly, publishing the photo, Hushang sought to differentiate from his German colleagues. The latter probably saw in his slippers the value of exoticism, while his Iranian friends on Facebook likely understand it as a comical critique of the system of value that pushes racial Others to perform cultural difference.

Yet, Hushang's stressing cultural difference does not only aim to mediate the value of exoticism, nor does is it always a critique of the prevalent system of values. In some situations, it is also a way for him to create capital from his Iran-specific resources by mediating cultural expertise that is sought after in the German social field of film professionals. For example, in August 2013, I joined Hushang at a beautiful, old cinema in the city center at the premiere of a documentary shot in Afghanistan. Except for the two of us, all attendees seemed to be of German origin. A middleaged woman, probably a member of the crew, came to tell him "Without you the movie wouldn't have been the same" (field notes August 2013). Later, he explained that he had taken the initiative to find and interview locals in order to enrich the documentary, building on his Persian language skills, his Middle Eastern physical appearance (he also donned Afghan clothing), and his professional know-how. Thus, he succeeded to have his Iran-specific resources valorized as capital. However, he told me that during the premiere, the presenter introduced him as an Afghanan inaccuracy that renewed his feelings of discrimination. Hushang corrected the presenter, explaining that he was from Iran. Building on his cultural difference for capital creation is risky, as the meaning of his Iranspecific resources easily switches from expertise to a lack of familiarity.

Thus, in the German social field of film professionals, depending on the project and the team, Hushang's Iran-specific resources may mediate a lack of familiarity and exoticism, or convey cultural expertise. Although he claimed not to believe that integration is possible, his politics of value consist in circumventing the barrier posed by his lack of familiarity by putting forward Germany-specific resources within the limits of his racial othering. Simultaneously, he exaggerates the performance of exoticism as an indirect critique, and mediates cultural expertise by acting as a broker in missions connected to the Middle Eastern context or migration in 
Europe. His boundary-making toward Germans also serves to build on Iran-specific resources for finding employment through cultural brokerage.

To return to our original discussion, I thus asked Hushang whether he thinks that the reason for the limitation of his professional opportunities could be that these colleagues have been able to build up more social capital among people in important positions in combining professional with friendship ties than him. Other than in classical, stabile working relations, where "weak ties" serve for professional ascension but are not essential to employment (Granovetter 1973, 1373), in the face of the high uncertainty that structures the film business, professionals need to rely on their social networks both to secure employment and to recruit a crew. Thereby, not only professional qualifications, and social skills, but, in order to increase work efficiency, also matching personalities, working morals and, in general, sympathy are taken into account (Apitzsch 2010, 414f.). Hushang acknowledged my point but insisted that he could not build such private ties with his colleagues. As we shall see later, his boundary-making toward German colleagues does not only derive from his feeling of cultural alienation or his efforts to act as a broker, but it also relates to the characteristics of work relations in the film business. Let me note at this point that Hushang and his German colleagues dispose of unequal potential for acting on the system of values that shapes the German social field of film professionals; both contribute to the creation and maintenance of social boundaries based on the idea of cultural and racial difference. Yet, in a context where "weak ties" are crucial for capital creation, their mutual boundary-making happens at the expense of Hushang's professional success.

Hushang also works within the transnational social field of Iranian film professionals: he occasionally accepts mandates from two successful directors living in Germany, whom he first met at an (today dissolved) association for Iranian film professionals in Hamburg in the mid-1990s. The producer Hessam offered him the only full-time job he ever accepted at his production company in Hamburg. Hushang also collaborated with Iranian film professionals outside Germany, in Iran and England. For example, he contributed to a video for an art gallery in Tehran. Besides, he sometimes does the German subtitles for internationally screened 
Iranian movies, some of which are produced by Milad. Finally, in his short documentary on the onward migration of an Iranian couple that does not find inclusion in Germany, he relied mainly on Iranian professionals. He claimed, that, in contrast to people he qualifies as his acquaintances, his friends are all Iranians.

It seems like a contradiction that Hushang claimed preferring sociability with Iranian colleagues, but also told me that he seeks to limit his relations with Iranian film professionals to the professional domain. The separation between the two is, of course, blurry, but, for instance, while he welcomed Milad to a day out with his close friends, he did not want to invite him to his home for dinner. This type of relation is reminiscent of his reluctance in ties with German colleagues, but the reasons he put forth are different:

You always have to see to move on yourself. Also, with Iranians, private and professional things often get mixed up. For me that's a reason why I don't want to get involved with Iranians too much. Everything gets mixed up. I just want to get along with you job-wise. But there everything works with relationships. Just like in Iran. "You do this for me, so I do that for you" I'm not up for this. I am very clear with that. (Field notes, April 2013)

Hushang's conflict between closeness and distance in relations with Iranian professionals results from his engagement with systems of value in the local social field of Iranian migrants and the German social field of film professionals.

First, through his boundary-making in his relations with local Iranians, we can see that Hushang values accurateness and punctuality. For example, he critiqued that Iranian working environments are chaotic and stated having adopted more structured German work ethics. Further, Hushang values economic independency and familiarity with German cultural contexts. We can see this reflected in the following discussion, when he told me that he had a new girlfriend.

Sonja "Nice! I'm happy for you! What does she do?"

Hushang "She is a salesperson for a pharmaceutical company. She moves around a lot." 
Sonja "So, she's from Iran as well?"

Hushang "Yes, she has been here for five years. But she speaks German fluently. That's important to me."

Sonja "That means, she's financially independent, does not wait for you to help her..."

Hushang "Simply, there are so many Iranians here who depend on welfare, don't speak German and so on."

Sonja "Oh, really? A lot?"

Hushang "Yes." (Field notes, February 2016)

His evaluation of other people's resources mirrors the values he himself tries to convey, which are some of the same he also seeks to mediate in his relations with German colleagues.

As we saw in Chap. 4, the system of value that prevails in the local Iranian social field coincides with those that shape numerous fields in Germany in prioritizing familiarity with German cultural contexts. The interpersonal perspective indicates another reason for this intersection, besides the historical valorization of anything Western among the transnational Iranian intelligentsia: the actual overlapping of social fields in everyday life. If German colleagues associate him with people who lack familiarity with German contexts, for example, by accidentally meeting him in their company on the street, this would stress Hushang's own unfamiliarity and enforce barriers of capital creation he meets in German contexts. In other words, what he does in relations that connect to the local Iranian social field may be perceived by agents with whom he shares an engagement in the German professional social field and thus influence his chances to create capital there. Patricia Ehrkamp (2006) observed a similar influence of the German hegemonic system of value on relations among Turks living in a socially disadvantaged neighborhood in Duisburg. However, in contrast to Hamburg's Iranian-Germans, Ehrkamp's interlocutors tend to reject the idea of assimilation and exclude Turks who convey too great a familiarity with German cultural context.

Second, Hushang's tendency to refrain from taking his relations with Iranian colleagues to the private level is inherent to the characteristics of Iranian film professionals' transnational social field. I suggested in the previous chapters, multiplex relations based on trust are an important 
element in Iranian sociability in Hamburg, not least as a reaction to the experience of barriers to capital creation in German contexts. Research observed similar trends in other migrant labor markets (Faist 1998; Bauder 2005, 92; Bloch and McKay 2014). In professional domains lacking formalized mechanisms of evaluation, the role of informal ties is similarly important as among migrants. Just as in the case of Iranian carpet merchants, the transnational social field of Iranian film professionals is both shaped by the context of international migration as well as by increased personal interdependency typical for the professional field. In both cases, cooperation and alliance are key values. As a result of these overlapping uncertainties, trust developed in multiplex relations is more important among Iranian film professionals compared to ties with and between their German colleagues.

Yet, social capital has its downsides. Alessandro Portes (1998, 15ff.; see also Portes and Landolt 1996) is among the first social scientists to study them in the context of migrant economies. Tight social networks often rely on boundaries that may also impede on insiders' engagements in other social fields. Furthermore, in what he calls "downward leveling norms", the valorization of alliance and cooperation within the group may engage the more successful in important material and immaterial social obligations that come at the expense of their own capital creation. For such reasons, migrants sometimes take distance from their peers (Zontini 2009; Cederberg 2012). Strikingly, Apitzsch (2010, 420) observed similar negative dynamics among German film professionals. Here, informal ties, in particular hierarchical ones, create obligations that prevent professionals from diversifying their resources and reduce their ability to adapt to changing conditions on the job market. These social obligations contradict the value of independence, which is central to Hushang's strategies of capital creation both in the local Iranian social field and among German film professionals. Thus, he seeks to separate professional and personal ties in order to mediate both collaboration and independence in the transnational social field of Iranian film professionals.

In doing so, Hushang tries to avoid the conjunction of uncertainties in the social field of Iranian film professionals. Significantly, he thinks about doing business with his two closest friends, Hossein and Amir, who are 
not in the film business. Moreover, both migrated at about the same time as him and dispose of an amount of Germany-specific resources more or less equal to his own. Based on these considerations, Hushang's relations with Iranian film professionals are analogous to relations between brothers discussed in Chap. 2: while ties between those who try to generate capital from the same resources tend to be ridden by competition, relations between people whose strategies of capital creation do not concentrate on the same social fields, like distant relatives or friends, may more easily be shaped by collaboration and solidarity (Bourdieu 1990, 170; Monsutti 2004, 2012). Hence, the idea to avoid obligations is the third reason, besides exclusion, cultural alienation and the aim to find employment as a cultural broker, why Hushang does not engage in friendship relations with German colleagues, either. Therefore, concentrating the main of his efforts to create capital on German contexts not only helps him to retain a greater independence, but, as we shall see later, paradoxically also sustains his chances to generate capital among Iranians.

While Hushang's struggle with the idea of assimilation contains his effort to balance dependence and independence in his relations with German and Iranian colleagues, how do the other film professionals engage with the conditions to capital accumulation in German and Iranian professional fields?

\section{Zian: What Barriers?}

Aged 34, Zian is the youngest of the film professionals, with least professional experience but great confidence in a successful career. Short and thin with black hair and eyes, he wears a designer-stubble, black-framed Ray-Ban glasses, speaks very fast, and preferably tells jokes. When I first met him, in May 2013, he lived in the HafenCity, a prestigious newly built high-end neighborhood in downtown Hamburg in a flat he shared with a friend, an Iranian who runs an international retail company. For financial reasons, he moved to Barmbek, an off-center middle-class neighborhood a few months later.

Tehran-grown, his family is originally from the northern Iranian province of Gilan. In Iran, he had studied natural sciences. During our first 
meeting, which was a formal interview, he told me his migration narrative: as he wrote articles for a regime-critical newspaper, he was persecuted and several times imprisoned by the Iranian state. In 2006, he came to Germany where he joined his brother and father who live in Frankfurt but then came to Hamburg and successfully applied for asylum. Since then, Zian did not return to Iran. He did the same foundation course as Hushang to study filmmaking, explaining the shift in his curriculum with the objective to find a different way to express political critique. At first, he applied to the renowned HfBK, where Hessam had also studied. As he received a refusal, Hessam and Hushang recommended him to study at the HAW. When I met Zian, he was finishing his bachelors and argued that university was mainly about building a professional network, as he could gain the skills through practice. Ambitious, for his masters he hoped to switch to a more prestigious university in Germany or abroad. Indeed, in 2014, he went to pursue his studies in Zurich for a few months.

Like Hushang, Zian mainly aims at creating capital in the German social field of film professionals. Stressing the value of professionalism, he discursively dissociated himself from Iranians whose company he shared during his early years in Germany:

Zian "There are many weird people here (Âdamhâ-ye ajib-gharib ziâd dâre injâ)."

At first, he got to know people who helped him in the asylum process, "miserable people (âdamhâaye badbakhti)", who struggled with their own asylum request. At that time, he got to know many Iranians who were in the same situation as himself. "You have much free time and rush into mischief." The way he talks about them suggests that he does not think of these contacts as positive.

I ask "What do you mean?"

Zian "Drugs and such kind of things." Before, he often went to Iranian discos. But today it annoys him that many women are highly dressed up and had gone under the knife (amal kardeh). He prefers natural beauty. Besides, they would also directly ask where you live and what kind of car you drive. "What business is it of theirs?" (Field notes, May 2013)

During his studies, in contrast, Zian got to know other students who were acquainted with the local conditions. "There you entered a different 
level" (field notes, May 2013). Through his contact with German and international fellow students and through professional experiences, he generated Germany-specific social and cultural resources. The fact that he is not yet officially on the labor market also preserved him from its competitive environment. A cover photo ${ }^{7}$ he posted on his Facebook account in early 2013 testifies to his good relations with young German professionals. It shows him amidst the crew of a short movie he directed. Most of the team look like Germans or at least Europeans, and two or three may be Middle Eastern. Among them is his close friend Parham who came to Germany at the age of 16 , today speaks German without an accent, studies sound technology and is, like Zian, involved in Golestan association. Thus, he has good professional contacts with some of his German classmates, which probably also extend to the private domain. Significantly, I once met him at a local film festival, and he was accompanied by a German colleague.

Putting forward Germany-specific social and cultural resources, he stated that, instead of going to Iranian discos, he now preferred to go to bars in the Schanzenviertel. Clearly, since several years, Zian endeavored to move out of exclusively Iranian social circles, not only in professional, but also in private life. While we talked, he played with a leather pocket full of cards in his fingers. It opened through the movement and I saw a German identity card inside.

Sonja "Did you become German?"

Zian "Yes." He took out the ID and showed it to me. 'So fast, after only six years!' I think. Without his glasses, without the beard and his hair appearing more brown than black, he somehow looked more German on the photo.

"I also changed my name into Mark Bar."

Sonja "Why?"

"Because I wanted it to sound more German." "Why did he choose this name?' I ask myself. Mark sounds like mard, which means "man" in Persian, and bar is German for "devoid" - a free man. Only someone who speaks both Persian and German can understand this signification.

\footnotetext{
${ }^{7}$ That is, one of the two most visible pictures of his account.
} 
Sonja "So, do you identify as German?"

Zian "No. In Germany, one always remains a stranger. I have many German friends. Good friends. They are also not very satisfied with the society and would like to go away. However, I also have many Iranian friends. In many other places, people are more open. It is still not 'normal' when someone is not from here. Many of my friends live in Canada and if they are asked where they are from, they say 'Canada'. Everybody there is from elsewhere and therefore people do not constantly ask you [where you are from].” (Field notes, May 2013)

In trying to generate capital from Germany-specific resources, Zian not only became a German citizen, but he also "Germanized" his name. His friend Parham did the same. They continued to use their Iranian names in Iranian contexts, however. Thus, not all Germany-specific resources are recognized as capital in the local Iranian social field. Such name changes are very rare among my interlocutors, compared to Iranians in other locations (Bursell 2012; Khosravi 2012). Zian also met limits to his capital creation among Germans, but, unlike Hushang, he does not draw boundaries based on cultural difference in order to convey exoticism or cultural expertise. He pointed out that he shares his feeling of alienation in German society with some of his friends who are of German origin; their relations are shaped by a system of value in which familiarity with German cultural context is not a key value, but cooperation and cosmopolitanism. Let me clarify that I understand the value of cosmopolitanism as distinct from that of diversity in that the willingness to engage with unfamiliar cultures is paired with a certain personal autonomy from the cultural context(s) one grew up with (Hannerz 1990). Thus, despite experiencing social exclusion in certain German contexts based on his cultural and racial othering, Zian successfully generates capital among German fellow students and junior film professionals.

Zian's engagements among German film professionals did not keep him from building up relations in the local Iranian social field. Many of his close friends, like his fellow student Parham, and his girlfriend, are Iranians. However, like Hushang, he privileges contacts with Iranians who dispose of important Germany-specific resources. For example, he told me that he now only goes to Iranian parties which are open to a 
selected public, such as the high-end "platin lounge". Thus, like Hushang, he is conscious about the importance of resources conceived of as Germany-specific for capital creation among Germans and possible downsides to tight social relations with Iranians who dispose little of these.

Nevertheless, he is not as wary as Hushang of social obligations in Iranian professional social fields. On the contrary, Zian is rather anxious to create ties among Iranian film professionals. In these professional contexts, the volume of their Germany-related resources is a priori secondary. Significantly, in his relation with Hushang and Milad, who are seniors in the field, he valorizes both their Germany- and Iran-specific resources. For example, when he first joined a meeting of Golestan association at which Hushang was also present, he told the group that a German short movie in which Hushang had collaborated was nominated for an international student award. Another example is a photo he posted on Milad's Facebook page in February 2013, when Milad was still based in Iran. It pictures himself, Milad, and his friend Parham discussing technical details on the set of Zian's short film. Following comments accompany the post:

Milad: I really liked the backstage of your film, Zian, and I am waiting for the shooting of your [first] motion picture. Say hello to everybody and well done!

Zian: Dear Milad, it was your presence that enriched our backstage.

Milad: My pleasure! (translated from Persian by the author)

Interestingly, Zian mobilized Milad's support for a movie realized with primarily German staff. This suggests that he must have created enough cultural and social capital among the team for him to be confident enough not to fear that his association with Milad, who disposes of important professional know-how but barely of Germany-specific resources, would enforce barriers based on his racial Othering.

Zian's valorizing his seniors' knowledge, and mediating cooperation, but also Germany-specific resources, helped him to create capital in the social field of film professionals: thanks to Sadegh's support, he got a mandate for making a documentary about Golestan's FusIran festival in the fall of 2013. During the event, he got to know two Iranian musicians, who subsequently hired him for realizing music videos or filming con- 
certs. Also, thanks to Yara, he became one of the presenters of the local film festival's section for historical Iranian movies in the same year. Thus, he does not shy away from building multiplex relations with Iranian professionals. His openness toward new contacts in the film business relates to the fact that he is a newcomer both in the German and in the transnational Iranian social fields of film professionals. Possibly because of his newness, he does not seem to expect obligations that follow from close relations.

In sum, solidarity and competition among Iranian film professionals, the tendency to build boundaries toward fellow Iranian film professionals or to deconstruct them is not only related to the primary importance of Germany-specific resources for the generation of capital among Germans and among local Iranians. It is also influenced, first, by their trust in the stability of inclusion in German contexts, that is mainly created in long-term multiplex relations with Germans, and, second, by their position in professional hierarchies.

\section{Milad, and the Protection of Façades}

I got to know 37-year-old Milad a mere few weeks after he came to live in Hamburg, in May 2013, during an afternoon we spent hanging out with Hushang and some other mutual acquaintances. The stout single with brown hair at shoulder length and blue eyes is rather introverted. As a passionate cook, he likes to talk about recipes. Milad does not speak German and has only a quite limited command of English. In the beginning of his stay in Hamburg, he mostly wore checked shirts and stonewashed jeans as they can be frequently seen on Tehran's streets. However, after one year, he cut his hair and adopted plainer, more local fashion. During the time I stayed in Hamburg, he lived in different places. First, he rented a room in the flat of a German cultural professional in Altona, an arty middle-class neighborhood. Then, he subleased a grim apartment full of dusty seventies furniture, situated in Hamm, a monotonous residential neighborhood. He liked to precise that the owner of this flat was a German professor at Oxford University. In between, he did not have his 
own room but squatted at different friends' places for a few weeks, mainly at Hossein's, who is also Hushang's friend.

Milad told me that his family is part of the Turkish-speaking Azeri minority, but I did not notice ethnicity to play a role in his relations with local Iranians. Back in Tehran, his hometown, he studied sociology before entering the film business. Milad made much of his career in collaboration with Sina, who is a director, just like himself. Together, they made several movies critical of the Iranian government some of which were rewarded at international film festivals. They shot the latest film without a government license. When the movie's participation in an international film festival was announced unexpectedly early, Milad left Iran on the spur of the moment to avoid imprisonment and came to Hamburg. Contrary to Hushang and Zian, he does not have family members in Germany. Still, he told me that he knew Hamburg well: as Sina had developed a foothold there, since 2008, he frequently came for festivals. Hamburg was also a location where they did shots for scenes of movies for which they did not have a government license.

At his arrival in 2013, however, Milad knew that his stay would have to be longer than the ones before. Nevertheless, he decided not to apply for asylum. Over a coffee we had in a bakery in spring 2013, he explained that he does not want to depend on German social services, and, distancing himself from asylum seekers, he argued that it is not truth, but a good story that is the basis for asylum decisions. Indeed, as I explained in Chap. 3, being considered a refugee (Flüchtling) can represent an important stigma and barrier to capital creation in German social fields, and, as a consequence, also among local Iranians. Moreover, he said "There is no point in being a filmmaker outside Iran" (field notes, June 2013); the sense he saw in his work was related to the socio-political situation in the country. He hoped for political change after the elections in June 2013, which may allow him to return. Thereby, an asylum request would have been a hindrance. Thus, he applied for a one-year work and residence permit with the help of a lawyer, instead. In late August 2013, he proudly presented me his newly issued document in the queue of a supermarket checkout. Thanks to his international professional success and to his economic capital, the German institutional system considered him a desir- 
able immigrant (Nohl et al. 2014, 3ff.). However, by that time, he already had new plans, and told me:

I want to have a base ( $p \hat{a} g \hat{a} h)$ in Hamburg, and the residence permit (eghthmat). Ideally, I would like to travel back and forth between here and Iran, and besides it is much easier to travel with a German residence permit. (Field notes, July 2013)

Indeed, with the idea to build on the cultural and social resources he had acquired through his work in Iran, as well as thanks to international rewards, he declared that his long-term aim was to open a film production company in Germany.

Therefore, he tried to invest in capital creation in the German social field of film professionals. As he once told me, he thought it was important not to limit his social life to contacts with Iranians. Through his previous stays, in particular thanks to Sina, he knew a few Germans in Hamburg working in the cultural sector and tried to build on these relationships. Indeed, Hans, the German editor of a local cultural magazine in his mid-fifties, not only rented out to him a room in his flat, but also remained a reliable friend after Milad moved out. For example, Hans invited him to spend Christmas together with his family. Through the older man, Milad tried to make new professional connections. For instance, once

he told me that he cooked âb-gusht [a very popular hearty mutton soup] for his landlord's guests. Hans had invited some friends, mostly Frenchmen. He showed me pictures (most of them seemed to be around fifty years old) and explained that, aside for a small remainder of rice, there were no leftovers. (Field notes, June 2013)

Putting forward Iranian recipes, his cooking talents, and hospitality, he sought to create capital among his invitees. Familiarity with German cultural contexts is, as we saw in Zian's case, not always a central value among German film professionals. Iran-specific resources may be interpreted as mediating the value of cosmopolitanism. However, his lack of language skills was an important obstacle to this effort. Arguing that he had lim- 
ited financial means, he did not go to language school, but tried to learn German by himself. He once went to a free class organized by a refugee help center, but he said that it was not well organized. After a year in Hamburg, he was still not able to have a simple conversation in German.

Instead, however, he had developed a knowledge of prevalent trends in German films: he told me about a plot he had in mind for a movie that seemed to represent the mix of comedy and romance that characterizes successful northern German movies made by, and dealing with, migrants and their descendants, such as Kanak Attack (Becker 2000), Kebab Connection (Saul 2004), Head-On ('Auf der anderen Seite') (Akin 2004), and Soul Kitchen (idem 2009). Indeed, Hessam also adopted this type of scenario in his productions. However, Milad told me that, before he could realize such a film, he had to get to know German infrastructure and working methods_- "culture" (farhang), as he said-better. Frustrated, he added that he only began to understand the social life of Iranians in Hamburg, not to speak of getting to grips with that of Germans. Indeed, the locally successful producer Hessam once told me that he had known many Iranian film professionals in Germany who could not "adapt to the tastes of the German public". He said, "You can't make films in Germany the same way as in Iran. You have to have an understanding of German taste and what the German public likes to see" (field notes, April 2014).

Contrary to Hushang and Zian, Milad did not complain about meeting barriers to capital creation based on his cultural or racial othering by Germans. What he did complain about is that he did not have access to German contexts other than the small circle of already acquainted internationally orientated film and cultural professionals. Instead of questioning the importance of conveying familiarity through Germany-specific resources, Milad put the blame on himself, for example, in saying that he is too old to learn the language. In sum, to his disillusion, Milad had to find out that his lack of Germany- or Western-specific resources impeded on the acknowledgment of the social and cultural resources he had generated among film professionals in Iran and among international film critics as a capital in German contexts.

The barriers Milad encountered in the social field of German film professionals increased his expectations in relations with Iranians in general, 
and local Iranian film professionals, in particular. Significantly, when I once found him lonely and depressed, he argued

Sonja "I know, being new in a country is difficult. You need time to find friends and find your way around."

Milad "Yes, but it is not as if I started from scratch. Luckily, I was in Hamburg and Europe many times before and I know many people here. I know Hushang for six years, and Yara for three years. That makes it easier." (Field notes, September 2013)

Upon his arrival in Hamburg, Milad thus hoped to build on social relations he had created during his previous stays. However, this turned out to be much more difficult than he thought, especially in the professional domain. The analysis of his relationship with Hushang will offer insights in the different reasons for Milad's difficulties.

Hushang was one of the persons Milad said he was closest to when he came to live in Hamburg. When Milad still lived in Iran, they met during Hushang's visits and the technician acknowledged the director's professional success, maybe with a hint of envy. To Milad, Hushang was one of the persons he looked up to as he thought he had realized to find his place in Hamburg. From the moment Milad immigrated there, however, an imbalance slowly developed between the men. Milad hoped for Hushang to help him create capital both among Germans and Iranians. For his part, however, Hushang was disappointed, as Milad had failed to employ him in his successful projects. Significantly, Hushang told me that it would always be a surprise when Milad and Sina released a movie. It was through his contact with local Iranian film professionals that Milad created Germany-specific social and cultural resources, such as knowledge about the dynamics of the German film business and its key figures. However, Milad told me that he was very secretive about his own projects and he did not involve these people in his professional projects although he was more advanced in the occupational hierarchy. He told me that this was because these films were illegal, "the team needed to be held small" (field notes, June 2013). Nevertheless, he continued to do so when he lived in Hamburg. For a documentary he wanted to realize in September 2013, he rented a camera from an Iranian friend who was based in Dubai 
and decided to film himself rather than to collaborate with Hushang or Zian. Thus, Hushang probably had the impression that their exchange was imbalanced — to his disadvantage.

As time passed, Hushang took his distances, and the two men saw each other ever more rarely. For example, in late August 2013, I was at a bar with Milad when Hushang called to invite me to the premiere of a documentary later on the same evening. He suggested me to bring Milad along, but when I told Milad, he was surprised that Hushang had not invited him personally and found some excuse why he would not be able to join.

In reference to the two dimensions of Hushang's boundary-making with Iranians, the first reason why the two men drifted apart was related to their strategies of capital creation in German contexts. In contrast to Zian, Hushang was insecure about his inclusion among German film professionals and did not want his association with someone lacking Germany-specific resources to add further difficulties. Milad, however, was dependent on contacts with people like Hushang in order to find an entry into the German social field of film professionals. The second reason is related to the important obligations in the field of Iranian film professionals: Hushang sensed that Milad had developed expectations from their relationship he was not ready to fulfill, on the one hand, because, as mentioned above, he evades important engagements with Iranian colleagues to maintain his independence. On the other hand, because, in Hushang's view, their exchanges were imbalanced. Tellingly, when I asked Hushang whether he had heard of Milad in February 2016, he told me:

Hushang "No, he did not get in touch. I contacted him once when I was in Iran [after Milad had temporarily returned there], but he didn't answer. Another time I met him on the street in Hamburg by chance." Milad had told me the same.

Sonja "But did you argue?"

Hushang "No, it's just like this. I don't want to talk badly about Milad, but I realized that, in general, people who come here from Iran expect that you do this and that for them. But that's not the way things work here. I first have to take care of my own life before I help others. They don't understand that." (Field notes, February 2016) 
Crucial to the argumentation of this chapter, the third reason for the dissolution of their relationship is related to the role of Germany-specific resources in boundary-making in the local Iranian social field. A discussion I had with Milad over a coffee almost a year after his arrival in Hamburg was revealing in this regard. At this point, the men had already stopped to see each other and Milad was disappointed by Hushang's lack of emotional support:

Milad "Hushang is always pessimist (bad-bin). He gives me little hope for professional success in Germany."

Sonja "He probably made bad experiences, feels disadvantaged in relations with Germans."

Milad "But he always says how good Germany is!"

I think 'Well, he can hardly admit that.'

Milad "Does he actually have a strong accent (lahjeh)?"

Sonja "Hushang speaks really well [German], almost without an accent." "And Zian?"

"Zian... yes, Zian has an accent. He does not speak very well. It's funny, in Persian he always speaks so fast."

"Yes, and he eats his words."

"Hessam also speaks almost without an accent."

"Yes, they all came here as twenty-years-olds. As refugees."

"Hushang and Hessam came as refugees?"

"I don't know for Hessam, but Hushang yes."

"He never told me about this!"

"Then better not tell him I told you. But Zian also came as a refugee and tells everybody. He doesn't have a problem with that." (Field notes, March 2014)

To understand the complex dynamics this quote reveals, Erving Goffman's (1990) concept of "impression management" is useful: we can conceive of Milad and Hushang as actors in a performance of self that was destined at each other. Other Iranian friends and acquaintances, as, for example, Yara and Hossein, sustained the impressions each one created of himself. Within these dynamics, Hushang tried to generate capital building on his actual Germany-specific cultural resources, while creating a fiction of having social capital in German contexts he actually lacked, because, as 
we saw earlier, he was not close with his German colleagues. Significantly, Hushang once told me

Iranians learnt how to adapt throughout the history of the region. So, they do it here [in Germany] too. But this often is only superficial. In work and everyday life, one gets along with Germans, but in private that's often different. Here, people treasure Iranian ways, but often Iranians don't want others to know or find out. (Field notes, April 2013)

Importantly, by "others" Hushang meant not only Germans but also people he categorized as Iranians. Thus, some of the Germany-specific resources Hushang had put forward and Milad had acknowledged as capital were not actually at his disposition. In the previously quoted discussion, I unwittingly created a disruption to Hushang's performance: in his absence, I offered insights into its "backstage", revealing his difficulties to generate capital in German contexts.

Correspondingly, Milad was truly surprised, inquired on the validity of his Germany-specific cultural resources (language skills), and revealed a part of Hushang's impression management he had sustained so far, namely the fact that he came to Germany as an asylum seeker. As he gained a greater insight into Hushang's backstage, he probably felt betrayed in his trust, because he contrasted Hushang with Zian's honesty, and thus greater trustworthiness. This also explains why Milad withdrew from his commitment to this performance and told me Hushang's "secret". In leaving out this episode of his life in our conversations, Hushang probably tried to suspend this categorization, as he had often experienced it as a reason for exclusion (Goffman 1963, 54ff.).

For his part, Milad also tried to manage the image Hushang (and other Iranians) had of him: in refusing professional collaborations with local Iranian film professionals, and building on resources he had created in Iran, he tried to sustain the image of himself as a successful producer. At first, I think that Milad was not completely aware of, and later tried to hide the fact that he was an even newer newcomer to the social fields of German and transnational Iranian film professionals than Zian. Once, Milad and I went to the Imam Ali mosque together, where we met an Iranian who told us boldly that he had lived in many different countries 
before settling in Sweden. He must have recognized Milad as a recent migrant from his way of speaking Persian and his clothes, and asked whether he was in a different country before, or came to Hamburg directly. To try to create Western-specific capital, that is, in this case capital other than Iran-specific, Milad explained that he had been in Turkey before, although this was only a two-month sojourn. As he tried to hide his unfamiliarity with Germany, he emphasized his independence and failed to convey collaboration, which, as we saw earlier, created barriers to his capital creation in his relation with Hushang.

The two men's impression management reveals a crucial observation. As we saw earlier, cultural and social resources which mediate familiarity with German cultural contexts are central for Iranians' capital creation both in most German contexts and among themselves. Therefore, most Iranians favor creating ties with people who have at least as much Germany-specific resources as themselves. These dynamics, however, may represent a vicious circle for people who experience barriers to the generation of capital in German contexts, as Hushang and Milad: to overcome barriers to capital creation among Germans, you try to generate capital among well-established Iranians, which in turn requires Germany-specific resources. In this situation, people may resort to impression management. This, in turn, leads them to be warier of close relations with other Iranians in fear that, through these exchanges, they discover the backstage of their performance. Beyond the key value of familiarity with German contexts, to create capital in the Iranian social field, people need to balance the mediation of both independence and collaboration. The equilibrium between these contradictory values, however, gets disturbed with such a withdrawal, as we saw in Milad's case. To sum up, the need to keep up impression management is the third reason why people like Milad and Hushang keep greater distance from other Iranians, in particular those engaged in their professional field.

In the light of this analysis, how can we explain Hushang's defeatism regarding Milad's professional plans in Germany? One, two, or maybe all of the following three reasons played a role in Hushang's discouragement. First, it may be the well-intended council of a friend, in which Hushang tried to tell him-based on personal experiences but without letting go of his own façade - that creating capital among Germans is not as easy as 
Milad thought it was. Second, it may be motivated by competition over professional success, insofar as it reflects Hushang's expectation that, if Milad realized his goals, he might outperform him without offering him any benefit from this success. ${ }^{8}$ Third, the fear may have played a role that, if Milad gained professional success among Germans, he might discover Hushang's true uncertainties in German contexts, which would devaluate the capital he holds in Milad's eyes. Thus, in alignment with my previous argument, as Milad and Hushang tried to generate capital in the same social fields, and reacted similarly to difficulties, that is, in trying to dissimulate them, their interests began to conflict and they ceased their exchanges.

Resuming shortly with Milad's trajectory, Hushang was not the only person who took distance from him. Yara, for example, also took her distances and even excluded him at several occasions. Looking back at his first year in Hamburg, he told me

that this period was difficult for him. That he spent much time being alone. That at the beginning he hung out more with the people, but then they all returned to their own businesses [donbâl-e kâr-e khodeshun budan]. He said that the people did not support him, the other Iranians. Most of them said "You won't find work here anyways." Hossein was supportive that is why Milad spent more time with him. He said his problem was that he was too old to learn the language well and that he did not know enough people. This was why anybody wanted to collaborate with him. He was not able to reach enough people. (Field notes, March 2014)

As the difficulties he met in creating capital both in local German and Iranian social fields impacted on his psychological well-being, he retired even more from sociability among Iranians. Of course, a few people did support him. One such person was Sina, with whom he was linked not only through long years of professional collaboration, but also through personal confidences. However, Sina soon returned to Iran. The other

\footnotetext{
${ }^{8}$ This was Milad's explanation: "It is difficult to make good movies abroad. But I want to try. Several people tell me: 'You are not going to make it; this won't work.' They are those who did not make it themselves. If they do not support me, then they should at least not discourage me. It's not as if I made $€ 200,000$ with that movie and I lead an easy life in Hamburg, as some people may imagine" (field notes, June 2013).
} 
helpers were not involved in the transnational social fields of Iranian film professionals. None of these efforts however allowed Milad to create enough capital to feel comfortable in Germany. After one year and a half, he decided to return to Iran temporarily to renew his social ties and bring more money with him, despite the risk of travel and occupational bans. To his luck, Milad met mildness from the part of the new Iranian government, and today, he moves between Tehran and Hamburg as he wishes.

What happens intra-relationally when friends and colleagues pursue individually competitive strategies of capital creation within and across local and transnational social fields?

The analysis of cooperation and competition between Hushang, Zian, and Milad showed that the local and transnational social fields of Iranian film professionals are marked by overlapping uncertainties deriving from migration and from the characteristics of the social fields of film professionals. Trust and reputation play an important role in sustaining cooperation in social relations among these professionals. We can see here an analogy to the structure of the transnational social fields of Iranian carpet merchants. At their difference, however, film professionals' professional success does not depend on their engagement in transnational networks, nor is it necessarily based on Iranian identifications. In contrast to carpet merchants who tend to maintain tight knit and multiplex relations, these film professionals rather seek a personal balance between cooperation and independence in order to navigate flexible capital creation in diverse professional social fields simultaneously.

Just like in the context of association Golestan, the generation of capital from Germany-specific resources was a major aspect of all three men's relations in the German and transnational Iranian social fields of film professionals as well as in the local Iranian social field. In Chap. 4, I showed that the importance of such resources is the result of the interplay of systems of value structuring social fields in Germany and Iran. The analysis of interpersonal boundary-making in this chapter indicates a second reason for the valorization of familiarity with German cultural contexts among Iranian, namely the actual overlapping of social fields in everyday life: Iranians tend to privilege being associated to others who have at least as much Germany-specific capital as themselves, in order not to enhance the Germans' perception of cultural and racial difference. In 
contrast to research among socially disadvantaged Turks (Ehrkamp 2006; Çelik 2015, 2017), this research joins extent studies in that my Iranian interlocutors reluctantly comply with rather than question the prevailing systems of value and the requirements of assimilation in their contact with Germans (Sanadjian 1995; Sadeghi 2018).

However, the comparison of the three men's boundary-making also shows that, while systems of value shape social fields, their effect on each agent may vary depending on his own professional position, but also on his gender, racialization based on individual physical features, but also on the extent to which past experiences of exclusion influence contemporary behavior. Comparing the two men's trajectory, we see that Hushang's own boundary-making toward Germans and his staging of Iranianness contributed to his (self-) exclusion. Brokerage, just like staging Iranianness, has relatively limited potential for changing existing systems of value. In contrast, the social ties Zian was able to create with Germans diluted the importance of perceived cultural difference and allowed him to present his Iranian identifications in a complementary, that is, non-exclusive, way. Thus, familiarity with German cultural elements does not have the same weight in all the German social fields of film professionals: among students and among higher ranked professionals in which Zian and Milad are involved, cosmopolitanism to a certain degree outweighs familiarity.

It is important to note that not all kinds of Germany-specific resources are similarly efficient in generating capital. In the German social field of film professionals, cooperation is a crucial value and disposing of Germany-specific cultural capital alone does not help migrants to mediate familiarity. As we saw in the case of Hushang, to overcome these limits, cultural need to be combined with social resources. Thus, depending on the social field, not only the volume but also the distribution of location-specific resources conditions successful capital creation.

Finally, the conflict between Hushang and Milad showed that the lack of Germany-specific resources may create a vicious circle. To avoid stigmatization and exclusion from their peers, migrants may resolve to impression management (Goffman 1990), in which problems in the generation of these kinds of resources become tabooed. This is also why, as in the introductory anecdote, narratives of successful Iranians rarely contain 
the difficulties they actually needed to overcome in order to create these educational and professional achievements.

\section{References}

Adelkhah, Fariba. 1998. Etre moderne en Iran. Paris: Karthala. Akin, Fatih. 2004. Head-On. Feature Film. Timebandit Films. . 2009. Soul Kitchen. Pandora Film Verleih.

Apitzsch, Birgit. 2010. Flexible Beschäftigung und soziale Netzwerke: Der Einfluss von Professionalisierung. Edited by Jens Beckert and Christoph Deutschmann. Wirtschaftssoziologie. Kölner Zeitschrift für Soziologie und Sozialpsychologie Sonderheft 49: 409-27.

Bauder, Harald. 2005. Habitus, Rules of the Labour Market and Employment Strategies of Immigrants in Vancouver, Canada. Social \& Cultural Geography 6 (1): 81-97.

Becker, Lars. 2000. Kanak Attack. Concorde.

Bloch, Alice, and Sonia McKay. 2014. Employment, Social Networks and Undocumented Migrants: The Employer Perspective. Sociology 49: 1-18. https://doi.org/10.1177/0038038514532039.

Bourdieu, Pierre. 1990. The Logic of Practice. Stanford: Stanford University Press. Bromberger, Christian. 2003. Iran, les temps qui s'entrechoquent. La Pensée 333: 79-94.

— ed. 2009. L'Iran, derrière le miroir, La pensée du midi 27. Arles: Actes Sud.

Bursell, Moa. 2012. Name Change and Destigmatization Among Middle Eastern Immigrants in Sweden. Ethnic and Racial Studies 35 (3): 471-487. https://doi.org/10.1080/01419870.2011.589522.

Cederberg, Maja. 2012. Migrant Networks and Beyond: Exploring the Value of the Notion of Social Capital for Making Sense of Ethnic Inequalities. Acta Sociologica 55 (1): 59-72.

Çelik, Çetin. 2015. 'Having a German Passport Will Not Make Me German': Reactive Ethnicity and Oppositional Identity Among Disadvantaged Male Turkish Second-Generation Youth in Germany. Ethnic and Racial Studies 38 (9): 1646-1662.

2017. Disadvantaged, But Morally Superior: Ethnic Boundary Making Strategies of Second-Generation Male Turkish Immigrant Youth in Germany. Identities 25: 1-19. https://doi.org/10.1080/1070289X.2017.1305218. 
Ehrkamp, Patricia. 2006. 'We Turks Are No Germans': Assimilation Discourses and the Dialectical Construction of Identities in Germany. Environment and Planning A 38 (9): 1673-1692. https://doi.org/10.1068/a38148.

El-Mafaalani, Aladin. 2012. BildungsaufsteigerInnen aus benachteiligten Milieus: Habitustransformation und soziale Mobilität bei Einheimischen und Türkeistämmigen. Wiesbaden: VS Verlag für Sozialwissenschaften.

Faist, Thomas. 1998. Transnational Social Spaces Out of International Migration: Evolution, Significance and Future Prospects. European Journal of Sociology 39 (2): 213-248.

Goffman, Erving. 1963. Stigma: Notes on the Management of Spoiled Identity. Englewood Cliffs: Prentice-Hall.

. 1990. The Presentation of Self in Everyday Life. London/New York/ Victoria/Toronto/New Delhi/Auckland/Johannesburg: Penguin Books.

Granovetter, Mark. 1973. The Strength of Weak Ties. The American Journal of Sociology 78 (6): 1360-1380.

- 1985. Economic Action and Social Structure: The Problem of Embeddedness. American Journal of Sociology 91 (3): 481-510.

Hannerz, Ulf. 1990. Cosmopolitans and Locals in World Culture. Theory, Culture \& Society 7: 237-251.

Khosravi, Shahram. 1999. Displacement and Entrepreneurship: Iranian Small Businesses in Stockholm. Journal of Ethnic and Migration Studies 25 (3): 493-508. https://doi.org/10.1080/1369183X.1999.9976697.

Pennsylvania Press.

2012. White Masks/Muslim Names: Immigrants and NameChanging in Sweden. Race \& Class 53 (3): 65-80. https://doi. org/10.1177/0306396811425986.

Langford, Michelle. 2016. Sohrab Shahid Saless: An Iranian Filmmaker in Berlin. Screening the Past 41. http://www.screeningthepast.com/2016/12/ sohrab-shahid-saless-an-iranian-filmmaker-in-berlin/

Mahdavi, Pardis. 2007. Passionate Uprisings: Young People, Sexuality and Politics in Post-Revolutionary Iran. Culture, Health \& Sexuality 9 (5):445-457.

Monsutti, Alessandro. 2004. Cooperation, Remittances, and Kinship Among the Hazaras. Iranian Studies 37 (2): 219-240.

2012. Trust, Friendship and Transversal Ties of Cooperation Among Afghans. In Local Politics in Afghanistan: A Century of Intervention in Social Order, ed. Conrad Schetter, 147-162. London: Hurst.

Naficy, Hamid. 2012. A Social History of Iranian Cinema, Volume 4: The Globalizing Era, 1984-2010, A Social History of Iranian Cinema. Durham/ London: Duke University Press. 
Neshat, Shirin. 2009. Women Without Men [Zanân Bedun-e Mardân]. IndiePix Films.

Nohl, Arnd-Michael, Karin Schittenhelm, Oliver Schmidtke, and Anja Weiss. 2014. Work in Transition: Cultural Capital and Highly Skilled Migrants' Passages into the Labour Market. Toronto/Buffalo/London: University of Toronto Press.

Olwig, Karen Fog, and Karen Valentin. 2015. Mobility, Education and Life Trajectories: New and Old Migratory Pathways. Identities 22 (3): 247-257. https://doi.org/10.1080/1070289X.2014.939191.

Ong, Aihwa. 1996. Cultural Citizenship as Subject-Making: Immigrants Negotiate Racial and Cultural Boundaries in the United States [and Comments and Reply]. Current Anthropology 37 (5): 737-762. https://doi. org/10.2307/2744412.

Ortner, Sherry B. 2013. Not Hollywood: Independent Film at the Twilight of the American Dream. Durham/London: Duke University Press.

Portes, Alejandro. 1998. Social Capital: Its Origins and Applications in Modern Sociology. Annual Review of Sociology 24 (1): 1-24. https://doi.org/10.1146/ annurev.soc.24.1.1.

Portes, Alejandro, and Patricia Landolt. 1996. The Downside of Social Capital. The American Prospect 26: 18-23.

Sadeghi, Sahar. 2018. Host Discrimination, Bounded Mobility, and Bounded Belonging: Iranians in Germany. In The Iranian Diaspora: Challenges, Negotiations, and Transformations, ed. Mohsen Mobasher Mostafavi, 50-73. Austin: University of Texas Press.

Sadjed, Ariane. 2012. "Shopping for Freedom" in der Islamischen Republik: Widerstand und Konformismus im Konsumverhalten der iranischen Mittelschicht, Kultur und Soziale Praxis. Bielefeld: transcript Verlag.

Sanadjian, Manuchehr. 1995. Temporality of 'Home' and Spatiality of Market in Exile: Iranians in Germany. New German Critique, Germany: East, West, and Other 64: 3-36.

Saul, Anno. 2004. Kebab Connection. Filmwelt Verleihagentur.

Schneider, Jens, and Christine Lang. 2014. Social Mobility, Habitus and Identity Formation in the Turkish-German Second Generation. New Diversities 16 (1): 89-105.

Zontini, Elisabetta. 2009. Enabling and Constraining Aspects of Social Capital in Migrant Families: Ethnicity, Gender and Generation. Ethnic and Racial Studies 33 (5): 816-831. https://doi.org/10.1080/01419870903254661. 
Open Access This chapter is licensed under the terms of the Creative Commons Attribution 4.0 International License (http://creativecommons.org/licenses/ by/4.0/), which permits use, sharing, adaptation, distribution and reproduction in any medium or format, as long as you give appropriate credit to the original author(s) and the source, provide a link to the Creative Commons licence and indicate if changes were made.

The images or other third party material in this chapter are included in the chapter's Creative Commons licence, unless indicated otherwise in a credit line to the material. If material is not included in the chapter's Creative Commons licence and your intended use is not permitted by statutory regulation or exceeds the permitted use, you will need to obtain permission directly from the copyright holder.

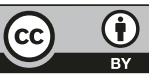




\section{6}

\section{A Festival at the Interstices of Value Systems}

It is a sunny but chilly day in April 2013. Behruz, a 27-year-old student who carries out his first project as a cultural organizer, his sister, his girlfriend, myself, and two other volunteers are on a promotional tour in Hamburg's commercial center. We distribute flyers and ask people to take pictures with the festival poster. We just reached a moment of disorientation, as we wait for Behruz to decide where to go next. He is hesitating.

I see three women in their late fifties and approach them spontaneously in Persian "Are you Iranian?" They are plainly but elegantly dressed, and one of them has a broken arm. Their hair is dyed in black. They stop. "Yes."

Sonja "Mâ ye festivâl... [I switch to German] um, sorry, I cannot say this in Persian too well. We organize a festival, three days in June, classical Iranian music." They look interested.

The one with the broken arm asks in Persian "Please say it in Persian, if possible."

I comply "Okay, I'll try. We want to make a festival -"

One of them corrects me "Organize."

Sonja "Organize. Iranian music at Hochsieben, during three days in June." The same woman says "Hochsieben is very good, it's a very good place." 
I hand them a flyer. "This is our chef [sic!]" I point to Behruz, who was talking to Jan, a German friend of his. He was crouched down, and stands up.

"How young he is!" they say.

The one with the bandaged arm "When is the festival?"

Sonja "June 11 to $14 . "$

"Oh, what a pity, I'll be back in Canada!" Behruz still keeps himself in the background. I show them the flyer and read the names of the musicians. They know [one of the bands] and the woman with the bandaged arm cheers when hearing the name of Taghi,${ }^{1}$ the headliner coming from Iran "I would have loved to come."

The one in the middle asks me to give her some more flyers "I have many friends; I'll give it to them."

Afterwards, Behruz asks me "How did you know they were Iranians?"

Sonja "You could see it. Besides, they spoke Persian together." (Field notes, April 2013)

In this situation, I was struck not only by Behruz lack of planning and professionalism, but also of the fact that he was reluctant to approach Iranians and speak Persian - a language I thought was his mother tongue. I assumed that displaying familiarity with Iranian cultural contexts was necessary to create capital among Iranians. Significantly, two months later, one of these women indeed came to the festival on two evenings. She greeted me and told me that our friendly encounter had inspired her to come. Even though the exchange was short, my personal interaction and my trying to speak Persian thus displayed Iran-specific cultural resources that mediated familiarity as well as cooperation. Behruz, however, was not as interested in putting forward Iranian cultural elements. Which were Behruz' politics of value and how did they inspire his strategies of capital creation aiming at the organization of an Iranian cultural festival? How was his approach received by Iranian stakeholders, German cultural organizers, and the visitors?

In the preceding chapters, I have highlighted a certain number of factors that play an important role in the way social boundaries are drawn between Iranians in Hamburg, which include, first, personal trajectories,

\footnotetext{
${ }^{1}$ Pseudonym.
} 
that is, the experience of doing kinship, place of birth, time and conditions of migration; second, the way they mobilize resources, in particular Iran- and Germany-specific social and cultural resources, in their strategies of capital creation; and third, the politics of value agents pursue within intersecting, partly contradictory systems of value that shape the social fields in which they are engaged. However, the interactions I analyzed so far were between people who shared an engagement in at least two of the same social fields. As agents that appeared in previous chapters come to interact in the context of Behruz organizing the Color festival, this chapter offers a perspective on the way alliances and confrontations emerge when each agent's strategies of capital creation relate to a variety of different systems of value.

This chapter is based on my active participation in promotional activities in the three months run up to the Color festival as well as in organizational tasks at the event itself in the spring of 2013. The argumentation will follow the way the complexity of the events was revealed to me, from the initial information I found about the festival in the internet to Behruz' fundraising strategies, and to the reactions of his interlocutors. The analysis allows me to situate arguments I made in the previous chapters and show that people of Iranian origin's interactions refer to multidimensional social fields shaped by competing regimes of value. Their social boundary-making thus needs to be understood as a tool that helps them to navigate barriers to capital accumulation they face in diverse local and transnational social fields.

\section{The Festival's Concept}

I first learnt about the Color festival through its presentation on a crowdfunding website. Crowdfunding is a method to finance independent artistic or otherwise innovative projects that was initiated in the late 2000 s and reached much popularity and success in the early 2010s. Via an online platform, people make a donation for a project of their choice. Necessary funds, however, have to be raised within a specific time frame. If the budget target goal is not reached, donations must be restituted to the donators and the project cannot be realized. The 2013 event was 
supposed to be the first edition of an annual festival, promoting intercultural understanding. The festival's concept was described as follows:

The Color festival is about a different country each year, and wants to present its melodies, its nature and its people through concerts, screenings and exhibitions. The goal: To change the perspective, to look beyond horizons, to inform and make people curious and, finally, to breathe new life into a long-established image. (www.startnext.de/000, assessed 17/03/2013)

The Color festival was scheduled on a three-day weekend in June. This kick-off edition was to be dedicated to Iran. The organizers presented the event as a reflection of and a contribution to Hamburg's diversity:

Our aim is to establish the festival [...], whereby the promotion of the hanseatic city's interculturality is paramount. We want to achieve this goal by organizing transnational cultural co-operation between the Orient and the Occident. It is the young and emergent artists in the domains of film, photo, music and plastic arts who have the possibility to influence intercultural co-existence. (www.startnext.de/000, assessed 17/03/2013)

The aim of the online crowdfunding campaign was to raise the amount of $€ 30.000$ - a particularly high budget for crowdfunding projects as the site stated. To incite the interest in the festival, it promoted a picture of Iran that is different from the negative image forged by Western mass media:

Each country has a beauty of its own. Iran's beauty however is too often concealed by misconceptions. The Color festival takes its spectators/visitors on a trip to Iran that will surprise, fascinate and ultimately change them. As the famous poet Hafez once said: "If you are not traveling and on the road, how can you call yourself a guide?" (www.startnext.de/000, assessed 17/03/2013)

Thus, in order to present an allegedly alternative image of Iran, the festival's program featured an exhibition of portrait and landscape photographs by Sebastian, a Bavarian who had spent a year in Iran, as well as three concerts of Iranian classical and folklore music, one each evening. 


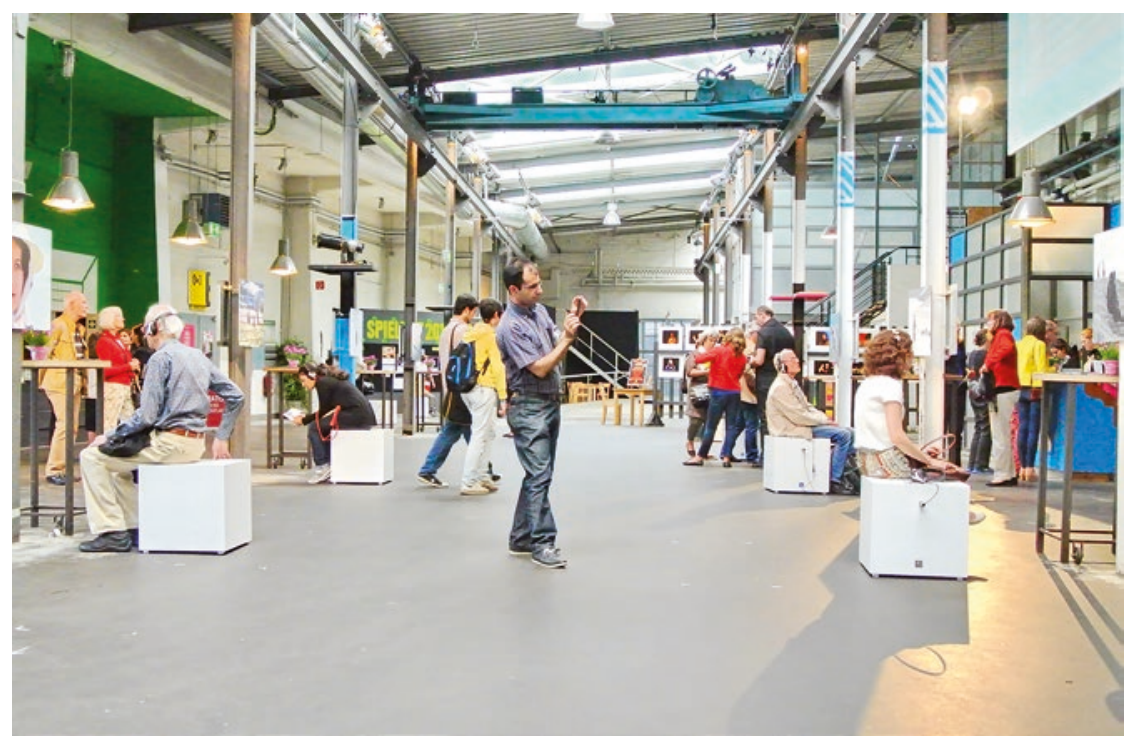

Image 6.1 Hochsieben's main hall with Sebastian's photo exhibition. (June 2013, author's picture)

It was constituted of two contrasting elements: romanticized rural life and folklore and Iranian classical music — a complex musical tradition whose audience and practitioners are mainly members of the urban cultural elite. Strongly supported by the Iranian government, this music tradition has experienced a revival since the Islamic revolution. Yet, the event's publicity was devoid of any political reference, if it was not promoting Iranian culture as apolitical. The event's location was Hochsieben, ${ }^{2}$ a former factory and one of Hamburg's most important local venues for avant-garde theater, dance, and music performances. The picture below (Image 6.1) shows the exhibition of Sebastian's photos in the location's main hall.

The project's presentation as an opposition to prevailing "misconceptions" about Iran reflects a somewhat educational way to counter barriers to capital creation based on the lack of familiarity in the German society, frequently observed in this research (see also Lamont et al. 2013, 132);

\footnotetext{
${ }^{2}$ Venue name changed.
} 
Behruz, in particular, sought recognition for his knowledge of Iranian classical music as a capital, which is, alongside Portuguese Fado, his preferred music style. Through his collaboration with a fairly successful German photographer and the locally well-reputed venue, the presentation also set forth important social resources that can be conceived as Germany-specific. While the crowdfunding campaign was devoid of any personal references, taking a closer look at the organizer's trajectory helps to understand how the project emerged and how this presentation targeting a rather German public fits into the project's concept.

\section{Introducing the Organizer}

The first volunteers' meeting that took place three months ahead of the festival in a café located in the main street of the yuppie-and-alternativeculture Schanzenviertel was where I first met Behruz in person. Fashionconscious in a down-to-earth way, Behruz wore a neatly trimmed designer stubble, chino trousers, flashy green sneakers, and a plain shirt. Tellingly, Karim, a 31-year-old volunteer of Iranian origin, once commented that "funnily enough, Behruz dresses a bit like rich kids but does not think like them" (field notes, May 2013).

The young man introduced himself as a German with Iranian and Iraqi roots, but stressed his identification with the city of Hamburg. Later, I learned that his parents grew up as Iranians in Bagdad, migrated as adults to Tehran in the frame of the Iran-Iraq war (1980-1988), where they lived in a district in southern Tehran popular with people from Iraq. Finally, they moved to Bavaria in the mid-1980s, where Behruz was born. Two years later, they came to Hamburg. Behruz told me that his father had been a lawyer in Iran and, according to his cousin, his mother's father had been a diplomat. Probably because his Iranian diploma was not recognized in Germany, he became self-employed as a carpet merchant like many other newly arrived Iranians in the 1980s and early 1990s. Research on Iranian migration observed this tendency toward self-employment also in other Western countries (Khosravi 1999; Moallem 2000). As Behruz father did not have a bazari background, he worked outside the established merchants' system of reputation (Chap. 3). Behruz did not 
say it explicitly, but I could sense that his carpet import company went bankrupt in the late 1990s, at the time of the market crisis. When I got to know Behruz, his father worked in a bookstore, but allegedly expected early retirement for health reasons in the following year. Behruz' mother worked as a physiotherapist. Thus, Behruz' family had experienced downward social mobility as they struggled with barriers to capital creation in German contexts.

Maybe as a reaction, family relations are very close, even spatially: Leyla, his 25-year-old sister who just finished her studies in French and Islamic Studies, lives with their parents, while Behruz and his girlfriend Maria, who is of Portuguese origin, live in a separate apartment in the family's semi-detached house in Bergedorf, a provincial middle-class residential suburb. Together, the family speaks both Persian and Arabic, and Behruz told me that he had been to Tehran to see his family a few times already. Not the father, but all three women took over much work for organizing the festival.

In a private conversation during that first meeting, Behruz told me his own professional trajectory: after graduating from high school, he wanted to study medicine. Both in Iran and among Iranians abroad, being a physician is one of the most prestigious professions, potentially generating much cultural and economic capital. As Milad, a film director, insightfully told me in another context, it is also a profession that offers relative economic stability, and therefore it is particularly interesting for people whose family does not have much economic resources. However, due to his low grades in high school, he had to wait before being able to enter this course. He ended up studying law instead, but quit after a year in favor of political science as a course of study. He was still an undergraduate when he decided to become an independent cultural organizer. The Color festival was his first project and he paused his studies to realize it.

His professional disorientation reveals both insecurity and high ambitions that are probably related to his parents' difficulties to create capital in German social fields - and as we shall see later also among Iranians. This is even more the case as he is their only son: assumedly, Behruz felt his parents' expectations over gaining upward social mobility. Engaging the German social field of cultural organization as a self-employed was 
surely daring, because Behruz and his family had relatively limited financial resources, he had no experience in event management or degree that would prove his qualification, neither, beyond sparse individual contacts, a professional network to rely upon for support. In sum, he barely had any resources from which to create capital. Plus, both his person and his project bore the danger of facing barriers as a consequence of their Iranian and foreign resources failing to mediate familiarity with German cultural contexts. As mentioned in the vignette that introduces this book, the staff at Hochsieben had almost refused his festival, if it was not for the support of a senior member, Anna. The analysis of his fundraising strategies will offer us an understanding of the way his strategies of capital creation in the German public sphere and the local Iranian social field interrelated with the systems of value by which they are shaped.

\section{Fundraising Through Sameness and Difference}

Back at the first volunteers' meeting, I found Behruz sitting around a table with Melanie, a German woman in her early twenties who had just returned from a long trip to Iran, and, to my surprise, with Yara, the psychologist and representative of the Golestan association (Chap. 3). He told us that he only raised a modest amount of donations, so far: his efforts to raise funds in the social field of the German public sphere through crowdfunding were of little success. Plus, the city-state's government denied his project subsidies. As a matter of fact, in the light of the approaching federal elections in fall 2013, Hamburg government's hands were tied when it came to any project having to do with Iran. This situation was not only due to the country's international political and economic marginalization under President Mahmoud Ahmadinejad, but also to the fact that the Social Democratic Party (SPD) in power at the Hamburg Senate had won the last local elections in 2010 partly thanks to its opposition to the former Christian Democratic Union (CDU) government's collaboration with the Union of Iranian Entrepreneurs (BIU) and the government of the Islamic Republic (Chap. 3). Significantly, in the same period, the cultural senator refused to grant BIU subsidies for organizing the performance of a Tajik ballet. 
In the local Iranian social field, Behruz complained, his fundraising barely gained attention, although, here too, he consciously presented the festival as politically impartial. At this occasion, he told Yara that he had contacted the Golestan association several months earlier to suggest collaborating, but did not receive an answer. Meanwhile he learnt that Golestan was preparing its own festival and proposed to present these events as two parts of the same festival. Yara politely refused the collaboration and stressed that Golestan had the support of the most important cultural organizer in Hamburg, as well as that of a well-known IranianGerman actress. The association obviously had been more successful in creating capital in the local social field of cultural organizers than Behruz, not least thanks to the resources of Sadegh and some other artist members, as well as the anti-Iranian-government rationale of the festival, supporting exile and underground musicians.

Yara, who is much more familiar with the local Iranian landscape and the power relations by which it is shaped than Behruz, advised him "If you want to get support from Iranians, you need names behind the project" (field notes, April 2013). She thereby pointed to the previously observed fact that cooperation, alongside independence and familiarity with German cultural contexts, is a key value and implied that people would be much more willing to support a project financially if it was patronized by someone they know and trust. In sum, in contacts with German institutions, it was the failure of his Iran-specific resources to mediate the values of democracy, human rights, equality, and ultimately familiarity, and among Iranians it was Behruz lack of cooperation that impeded on his fundraising at this stage.

In the course of the discussion, Behruz announced how he wanted to deal with these constraints to capital creation, namely in putting more effort in raising funds among Germans through the crowdfunding campaign. Behruz wanted to build a career in German contexts. However, although he was not explicit about this, in attracting a German audience he also hoped to gain the interest of Iranians. Significantly, during the presentation of a fundraising concert in front of a largely Iranian public of about 60 people, he stated, "Tonight, all the event is in German only, because it is also the aim of the festival to address Germans" (field notes, May 2013). How did he try to generate capital in these two social fields 
simultaneously? A look at his agency in the local Iranian social field will offer the necessary insights.

First, Behruz built the festival's concept on an opposition to established Iranian cultural organizers whose events are typically designed for an exclusively Iranian public. Several times, notably in a discussion with Yara during our first meeting, Behruz critiqued another organizer of Iranian classical and folklore music concerts as "unprofessional" for inefficient time management during the event and bad sound quality. Moreover, he despised the annual pop-music concerts of famous singers from Los Angeles, the ex-territorial hub of the Iranian pop-music industry, for their festive atmosphere as shallow entertainment.

Behruz "I find it stupid just to party. That's also what all people in Iran want. I want to convey content. I don't understand the sense of it."

Sonja "Well, it serves to cultivate social contacts."

Behruz "Honestly, I don't know how you party, but $I$ don't cultivate social contacts with it. You cultivate contacts in a café during the day, or in a restaurant in the evening. Partying, that comes from the West, from Europe and America." (Field notes, July 2013)

Behruz' evaluation shows a correspondence with the system of value put forward by the Iranian regime. It idealizes the image of the modest and profound "authentic" Iranian and opposes it to the superficiality of people under Western cultural influence (Khosravi 2008, 32ff.). Simultaneously, his despise for pop music converges with the system of value that shapes the social fields of Iranians who identify as "intellectuals". I heard Yara and Nazanin, a 60-year-old educational advisor and daughter of a professor, make similar judgments. Thus, Behruz argued that his festival would introduce "a new level" to the repertoire of Iranian cultural events in putting forward resources that mediate familiarity with German as well as Iranian cultural contexts, professionalism, independency, and education.

Concretely, that meant that he marked the event off through a neat layout of publications in German and an avant-garde venue, which, until then, had never hosted any Iran-related events. Before, Iranian classical or folklore music concerts mostly took place in the more traditional 
Laeiszhalle, a neo-baroque concert hall, or at the Hamburg University auditorium. Their publicity is mostly in Persian language and displayed only in shops and enterprises that are primarily frequented by Iranians.

We, instead, distributed flyers in middle-class and student districts such as Altona, Schanzenviertel, and round Hamburg University. Once, in a group of volunteers, we discussed the possibility of printing Persian and German bilingual flyers, when Behruz objected "Have you already seen Iranian flyers? They are completely overloaded. My design is minimalistic, that's how it stands out" (field notes, April 2013). The festival logo was in two colors only, and publications were almost exclusively in German (and partly in English). When I distributed flyers among Germans, I noticed that the design was well received, maybe because it reminds that of a British government World War II poster "Keep calm and carry on" that became a very popular decorative theme since the 2000s.

The festival slogan, in locally spoken Low German and Persian, symbolizes more than a statement of local diversity. It represents Behruz' claim for culturally pluralistic identifications, which expresses his politics of value in German contexts aiming at making the exoticism conveyed by Iran-specific resources familiar through cultural education. In contrast to Afshin, who tried to promote diversity beyond cultural and ethnic identifications as familiarity (Chap. 4), Behruz advertised diversity in the sense of interculturality, thus maintaining cultural and ethnic categories. Significantly, according to a magazine article, Behruz said that "Iranians would not succeed in presenting themselves with cultural self-confidence as part of the German society" (Brehmer 2013).

As precedingly discussed, mediating familiarity with the German cultural context is an important factor in boundary-making among Iranians in Hamburg. Thus, in putting forward important Germany-specific resources and attracting a German public, Behruz wanted to address Iranians who have been successful in creating capital in German contexts. His attracting successful Iranians was part of the aforementioned politics of value. In Chap. 4, I showed that the German assimilationist approach to immigration leaves little space for pluralistic identification. In very simple terms, either you are German or a foreigner, but you cannot be both. In order to claim culturally pluralistic identifications, Behruz thus 
needed to mediate familiarity with Iranian cultural contexts, but also professionalism, lest he would fail to convey familiarity with German contexts. Revealingly, at the end of the first concert, Hassan, a short Iranian man in his sixties, who distributes publicity and sells tickets at every Iranian event, spontaneously stepped on the stage and danced. The mostly German public clapped their hands and I laughed, but Behruz, who sat next to me, was angry and told me that he "did not find that funny" (field notes, June 2013). Considering these conditions, having Iranians with important Germany-specific resources attend the festival sustained Behruz' politics of value in German social fields that aim at making the exotic familiar. However, there was another important reason to Behruz' limited performance of Iranianness as we will see in the following paragraphs.

The second aspect of his agency in the local Iranian social field was that Behruz presented himself as a German-Iranian but was reluctant to put forward Iran-specific social and cultural resources. As noted before, Behruz lacked social capital among Iranians, that is, contacts who could vouch for his trustworthiness. Plus, he disposed of only a very limited time frame to raise funds. Following Marcel Mauss (1966), to build up trust, time, frequency, and reciprocity of exchange are needed in which honesty and reliability can be put to the test. Yet, although he wanted and needed the support and attendance of Iranians, Behruz was loath to collaborate with Iranians. Significantly, he explained during a volunteers' meeting, that calling or writing to Iranians to ask for funds was his mother's task "because he would not know how to talk to them" (field notes, April 2013). There are two main reasons why Behruz quite consciously limited his contacts with Iranians.

On the one hand, as discussed in Chap. 5, tight social relations between migrants often also entail interdependence and social obligations that may impede on a single individual's strategies of capital creation. For example, Behruz told me that if they were to support him, Iranians would be expecting something in exchange. He thus offered free entries to economic stakeholders such as Abtin-mostly people he did not knowhoping that they donate money or bring their family and friends along. On the one hand, in avoiding establishing multiplex (i.e. professional and personal) relations, Behruz tried to escape obligations he would have 
to fulfill after the festival. On the other hand, building too close relations may have mitigated his own strategies for generating capital in this festival. This is certainly one of the reasons why, besides Behruz mother and sister, among the 14 members of the festival team, there were only two Iranian volunteers including myself.

On the other hand, ironically, Behruz had social obligations through his engagement in multiplex relations with certain people and institutions, which were interwoven with his personal identifications. Indeed, while he presented himself as German and Iranian in any public context in the frame of the festival, he often spoke of his Arab origin to me in private. He thus elided his Iraqi identity in his contacts with Iranians. Yet, he created boundaries toward Iranians each time someone did not give him the support he hoped for. The reason is that he emotionally distanced himself from the people by whom he feared being rejected.

Revealingly, after the festival, Behruz told me "Iranians provided zero support. My mother told me so from the beginning, but I didn't want to accept it" (field notes, July 2013). Strikingly, he never attributed similar behavior by Germans to their national or cultural identity. It appears thus that Behruz mother maintained important social boundaries toward Iranians. This is probably because their Iraqi identifications may have led people to categorize them as Arabs, which is a highly discriminated population in Iran (Elling 2013, 167f.). Behruz' cousin also confirmed: among Iranians abroad, she frequently meets barriers to capital creation based on her Arab name failing to convey familiarity with Iranian cultural contexts.

As argued in Chap. 2, ethnic and national identifications are fluid and shifting, contextually shaped by social and institutional categorizations and the experience of kinship. In concealing his Iraqi identifications, Behruz tried to suspend the creation of ethnic boundaries which could impede on his capital creation in the local Iranian social field. However, as family relations were tight, and his mother and sister were highly involved in the organization of the festival, loyalty to the family negatively influenced his generation of capital: proving his mother wrong would have endangered the family cohesion that was built on differentiation from Iranians. In Alejandro Portes' $(1998,17)$ terms, Behruz family obligations thus became "downward levelling norms" (see Chap. 5). In concurrence with my observations among the children of early merchants 
(Chap. 2), Behruz' engagement in Iranian social fields was thus shaped by his family history and involvement in kinship relations. Focusing on capital creation among Germans was hence a way for Behruz to circumvent family conflicts and overcome the barrier his Iraq-specific resources would create by failing to convey familiarity with Iran.

Besides his family, Behruz had engaged in another alliance that made him doubt of his inclusion in Iranian contexts. First, I did not understand why, in our last preparatory meeting in June 2013, he said "some people would think that we collaborate with the Iranian government and therefore won't come" (field notes, June 2013) or even vandalize. However, on the second day of the festival, just before the headliner's concert, I noticed that Behruz was particularly nervous. When a family of five with veiled women hurried inside, and I saw Behruz relieved, I guessed that they were invitees linked to the Iranian government. A discussion with Karim after the festival confirmed my supposition. When I asked Behruz afterward who he had asked for support, he was straightforward:

Behruz "We contacted the [Imam Ali] mosque, of course. They couldn't help us, but they referred us to Berlin."

Sonja "Why Berlin?"

Behruz "The department for cultural affairs of the embassy. They helped." Sonja "What did they do?"

Behruz "They paid for Taghi's flight."

Sonja "Ah, okay."

Behruz "That's just normal. That's what they usually do. Also [the embassies of] Portugal and France." (Field notes, July 2013)

The Iranian embassy had contributed with a $€ 10,000$ grant to the festival's budget. In this context, I understood why Behruz repeatedly defended the Iranian government and political system in our conversations. When I met him on the day after the Iranian presidential elections in 2013, he was outraged at having seen the Iranian Consulate General's entry decorated with green tags and toilet paper, and stressed that "after all, this is our consulate, the representation of our country, no matter what government there is." On the same day, we met a Marxist, the 60 -year-old daughter of a binational couple who tested our political 
allegiances: "In Iran, people are unfree." Behruz answered "People are more happy in Iran than here. The people you see on Sebastian's pictures are not oppressed" (field notes, June 2013). Besides, while Behruz was not religious, his mother and sister were practicing Muslims. Nationalism is here intertwined with regime-loyalty and religious adherence.

Political and religious orientations often give rise to social boundaries between Iranian migrants (Nassehi-Behnam 1991; Sanadjian 2000; Moghadam 2013). Islamophobia and the promotion of "non-Islamiosity" is widespread among the majority of middle-class Iranians in England and Sweden (Gholami 2015; Khosravi 2018). Religious adherence is thereby often conflated with government loyalty, in particular among long-established migrants. In Iran just like among migrants, the relation between these interests as well as differentiation between political factions is much more complex (Adelkhah 1998; Bajoghli 2019). Fragmentation based on ideological convictions have been observed among migrants from other countries, too, in particular those, who, like Cuba and Armenia, are shaped by important political changes or conflicts (Pedraza 2003; Kokot 2009). "non-Islamiosity", we can see in this context, is an important value in the local Iranian social field that connects to the values of democracy, human rights, and equality, not least because of growing anti-Muslim racism in Germany (Fekete 2004; Shooman 2014) and because Hamburg hosts numerous institutions of the Iranian government. Thus, if Behruz concealed his collaboration with the Iranian government, it was because he was apprehensive that it conveyed a lack of non-Islamiosity that would create a barrier to his capital creation among Iranians.

Erving Goffman (1963) identified practices of concealing as ways to circumvent social exclusion. Similar to dynamics observed among film professionals, Behruz' individual convictions as well as his familial and political allegiances led him to engage in complex impression management (Goffman 1990). The fear of people discovering the backstage of his performance, in turn, contributed to his wariness of collaborating with Iranians.

In sum, Behruz focused on capital creation among Germans in order to follow his politics of value both in the German public sphere and in the local Iranian social field. First, in the German public sphere, he put 
forward Germany-specific resources to convey assimilation and familiarity. Simultaneously, he set forth certain Iran-specific resources to claim culturally pluralistic identifications and cultural expertise. In doing so, he hoped to overcome the limits posed by his lack of professionalism, financial capital, and social contacts and bridge the prevailing conflict between the values of exoticism and familiarity by making the exotic familiar. Second, in conveying familiarity with German cultural contexts in the local Iranian social field, he targeted an Iranian public that disposed of important Germany-specific resources. Their presence in the festival, in turn, sustained his politics of value in the German public sphere. Third, he mediated independence and evaded cooperation with Iranians because, on the one hand, he wanted to circumvent interdependencies and social obligations in internal relations. On the other hand, he tried to conceal his Iraqi identifications and his collaboration with the Iranian government in order to prevent the emergence of barriers to his capital creation both among Iranians and among Germans.

Discussing the way Behruz festival was evaluated by different Iranian interlocutors will allow me explain why he was not satisfied with the festival's outcome.

\section{Discrepant Reactions: Competing Systems of Value}

While preparing the Color festival, Behruz contacted many Iranians for different motives and with various objectives. Danial, the entertainer; Yara, the Golestani; the businessman Javid; Ziba, the cultural organizer; and Nazanin, the educational advisor, are all engaged in some of these social fields: the German public sphere, the social field of local cultural organizers, the local Iranian social field, as well as the transnational social fields of Iranian businessmen and artists. As you can see in the graphic below (Fig. 6.1), these social fields intersect in very particular ways for each of these agents, and so do the systems of value by which they are shaped. In this section, we will see how their involvement with these conditions influenced their relation with Behruz. 


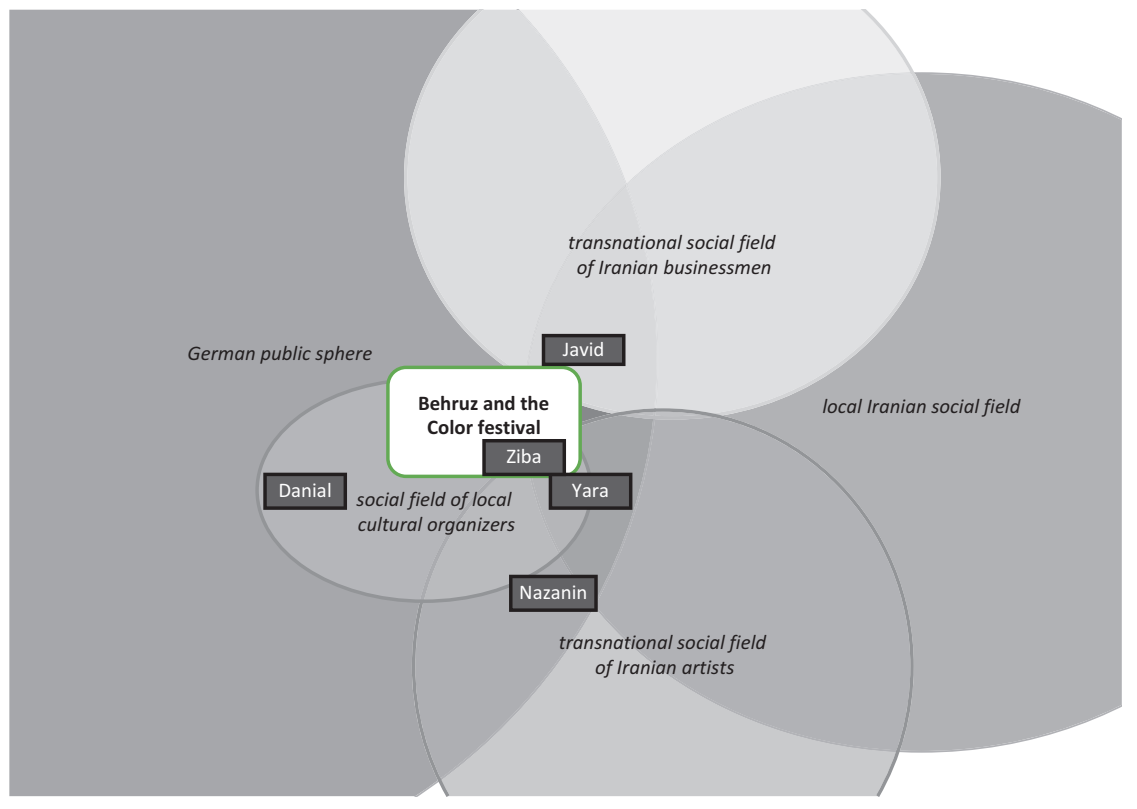

Fig. 6.1 Behruz' potential Iranian allies and their positionalities at the intersection of tridimensional social fields

Danial started his career as an entertainer by hosting literature competitions geared to a mainly young and rather German public. At the time of the festival, the eloquent 32-year-old began to extend his work to the national level, as well as in other German-speaking countries. Iranianborn, he came to Germany at the age of five. Putting forward Iranian identifications is a crucial part of his professional image. On shows, he gets usually introduced as "the great mogul of all Persian wordsmiths" (field notes, June 2013). His important local identifications, which he expresses in a dry, straightforward humor, an articulation that mixes Low German enriched with youth culture slang, however, are just as central to his persona. Behruz wanted him as a host for the festival because the values Danial puts forward would sustain his endeavor to make the exotic familiar by claiming pluralistic ethnic identifications. But, to his great disappointment, Danial's fee was higher than Behruz could afford. Plus, the entertainer rejected the plea for gratis publicity in one of his shows. In an interview, Danial told me why he refused the collaboration: 
Danial "I work, um- I mean, I never work with Iranians."

Sonja "Okay."

Danial "I decline all offers, because - most of it is always, I mean, most, in my experience - so far all they wanted was always very brazen and very insolent: 'Come, Iranian, we are also Iranians, help us!' [...] I'm no Iranian artist. I'm an artist, and I'm, like, from - from here. [...] In my domain, in what I do, I'm absolutely leading. I don't need any Iranian to tell me - like for the um... what was the name again? For the Color festival."

Sonja "What do you mean?"

Danial "He contacted me, he contacted me, the agency ... five, six times."

Sonja "Okay."

Danial “'Yes, do this, and wonderful...' and my agency writes - see, they are Germans, they are no Iranians! Well! And he writes back 'Yes, of course, three days, and how much does Danial charge?' They said 'Soand-so much.' 'Oh, well. That's a lot, but okay, we would like to have him for three days' and then, five days later another email 'We have to see if we can get the money.' Then, after two weeks he says 'We don't have enough money.' This was evident from the beginning! 'Um, can't he do it like this [i.e. for free]?' Then, the agency answers 'That's asking a bit too much, don't you think? Doing a festival presentation for three days in a row like this?' And then, in the end: 'But this will get him very far' or 'much farer.' 'It is an experience he...' That's why I'm happy to have an agency, because that's when I hang up! When people say such things! With Iranians - I don't like Iranians. I work... Except if they are professionals and very good in what they do - which is very rarely, very, very, very rare, but otherwise they always think you owe them something." (Interview, July 2013)

The transcript strikingly shows that Danial did not acknowledge Behruz' Germany-specific resources as capital and thus created a boundary, distancing himself from the young man. As the graphic above indicates, Danial positioned himself in the social fields of the German public sphere and the local social field of cultural organizers. He did not want to be involved with Iranians in his professional life in any way. He thus evaluated Behruz' resources based on the systems of value that dominate these fields: Behruz' Iran-specific resources, plus his putting forward the value 
of cooperation together with a lack of solvency, in Danial's view, hinted to a lack of professionalism, independence, and ultimately familiarity with German cultural contexts.

It is thereby important to consider that Danial's and Behruz' politics of value in German social fields were quite similar, just like the reason why both evaded collaborations with Iranians. Danial told me that he had experienced social obligations and downward leveling norms in contact with people he identified as Iranians_-including his parents - as hampering his professional advancement among Germans. Significantly, he also refused to host Golestan association's FusIran festival, but accepted to present an Iranian festival in 2017 which was organized by two Germans, when his career was much more advanced. At the difference of Behruz, however, Danial did not need Iranians' collaboration to create capital among Germans. Therefore, their strategies of capital creation were incompatible.

With Yara, it was quite the contrary. Behruz' and Yara's politics of value did not coincide, but their strategies of capital creation were similar, with the exception that Yara was much more involved of the Iranian social field than Behruz. We saw in Chap. 4 that, just like Behruz, Yara was a newcomer to capital creation among Iranians. Thanks to her involvement in Golestan, she just began to engage in the transnational social field of Iranian artists and that of local cultural organizers. At the intersection of these social fields, Yara strove for upward social mobility by cooperating with Iranians who disposed of particular Germany-specific resources. She valued Behruz' effort to make the exotic familiar, which resonated with her own strategies of capital creation in German contexts. At that time, the former oppositional activist, who could probably tell Behruz' political views by the festival program, also did not bother that they failed to mediate democracy.

Therefore, she initially offered Behruz her help, even though she did not have the time to create trust, and even though her association refused an official partnership: Yara lent Behruz her car so he could flypost and introduced him to Iranian cultural stakeholders. In return, they convened that Golestan would be allowed to distribute publicity for the FusIran event during the Color festival. Yet, the exchanges with Yara were exactly the kind of engagements that the young man sought to avoid. 
Thus, he soon began to refuse her help, creating boundaries that impeded on Yara's capital creation. She, in turn, critiqued his lack of cooperation, and, after the event, she also condemned his collaboration with the Iranian government. On an afternoon we spent together at obsequies (khatm) in September 2013, I mentioned that Behruz wanted to organize an event to take place at the same time as the FusIran festival.

Yara "He always makes very unclever moves. I don't understand why he absolutely wants to organize the small festival in October, although the date of our festival has been fixed a year ago? He is no real competitor to us, but nevertheless, it's a matter of principle. We offered our help many times, but he never accepted it."

Sonja "Did he actually ever propose his help for your festival?"

Yara "No. He always says, he is no Iranian, yet everything in him is so Iranian.” (Field notes, September 2013)

Yara's comment hints to Behruz' contradictory approach to cooperation with Iranians: he may put forward Iranian identifications in order to stimulate alliances, as he did with Danial, and (sometimes even simultaneously) deny both, depending on whether or not these collaborations (continue to) foster his strategies of capital creation and comply with his politics of value. As we saw in Chaps. 2 and 3, time is an important factor in internal relations, as temporalities of cooperation determine and are determined by the level of compatibility of two agents' strategies of capital creation and politics of value. The longer the collaboration, the more important it is that not only strategies of capital creation are compatible, but that also politics of value coincide. Behruz and Yara's cooperation was short-lived, as strategies of capital creation among Germans were similar, but they did not share the same politics of value among Iranians.

Behruz' failing to mediate cooperation was also why Javid, the president of BIU, refused his support. After the festival, Behruz told me indignantly that he had presented the project to the corporate consultant, asking for financial support and to borrow a few Persian rugs for the decoration. However, he was left without an answer and learnt later that Javid did not even discuss the offer with the members of the association, as promised. In an interview on the telephone, I asked Javid for his point of view: 
Basically, they came to see me and they got me exited, but I don't get anything out of it - if I spend money, as it were, I don't get anything out of it. Um, that means, you should analyze your sponsors. What do they get out of it, if they give me money? That means, you have to - two hands: one washes other [sic!]. What does the donor get? Besides a donation receipt and this restitution. If this is not the case, you don't get anything. (Interview, June 2014)

Contrary to Yara, Javid evaluated from the outset that the restitution Behruz offered was not worth for him to invest in this project: as an international entrepreneur active both in Germany and Iran, and as the president of BIU, Javid successfully creates capital in the transnational social field of Iranian businessmen, in the German public sphere, and in the local Iranian social field. He considered Behruz' request for cooperation, because the festival presented resources that convey both Germany- and Iranspecific resources which were relevant to him. However, not having any restitution of interest revealed a lack of professionalism and autonomy. Based on this failure he judged that the project would be an unprofitable investment. In contrast to Yara, who wanted to create capital through long-term exchanges, Javid looked for immediate economic benefit. Besides, what Javid did not mention was that his refusal also relied on their competitive strategies of capital creation: Behruz tried to establish himself, alongside Javid, as a coordinator in local projects with the Islamic Republic of Iran. Nevertheless, to confirm his importance as an Iranian stakeholder, Javid anyways made an according to him "moderate" donation of $€ 500$.

Ziba, a cultural organizer and Ayurveda therapist in her mid-forties who came to Hamburg as a teenager, did not care much about the restitution in cooperation with Behruz, nor about his solvency, nor his professionalism, despite being involved in the German social field of cultural organizers and in the local Iranian social field. She provided infrastructural and social support, for instance by inviting him to her Persian-German language broadcast on an independent local radio station. I also witnessed her taking Behruz' defense in front of critiques from Hochsieben's staff.

Her support relied on the fact that Behruz' strategies of capital creation among Iranians suited her politics of value in this social field. Significantly, in an interview after the festival, she told me that 
she offered Behruz her help because he does not belong to any group, just like herself. She works with different groups, and people frequently accuse her jokingly of cooperating with "competitors". She does not like this, but she likes people who are courageous and try something new, and that's why she supported Behruz. (Field notes, July 2013)

Ziba told me that in her experience, Iranian representational activities in Hamburg were often dominated by older people whose political views impeded on their creating sustainable collective strategies of capital creation in German contexts. As you could read in the introduction to this book, the unmarried woman also likes to challenge the prevailing evaluation of gendered behavior in the local Iranian social field. Moreover, in the German public sphere, they shared an interest of "making the intercultural a normality", as she put it (field notes July 2013). Thus, the value she saw in Behruz and his project was indeed its novelty and its promotion of the exotic as familiar. Strikingly, the fact that they were engaged in the same social fields followed similar strategies of capital creation and had similar politics of value - apart from his involvement with the Iranian regime which she never mentioned-did not create a barrier to her helping him create capital both among Germans and among Iranians. Just like Zian in Chap. 5, she seemed to be confident enough of her inclusion in both social fields not to fear competition. Thereby the economic success of the festival was of secondary importance to her.

Finally, there was the volunteer Nazanin. It was through me that the educational advisor in her early sixties heard about the festival and became engaged as a volunteer. Living in Germany since the 1960s, she is married to a German lawyer, has only very few Iranian contacts, and did not travel to Iran since several decades. Nazanin mainly focused on creating capital among Germans. The daughter of a professor attributed much importance to her social standing. She lived in an upper-class neighborhood, cared to be always well-dressed, and discursively sought distinction from Iranians who had less Germany-specific resources as her, as, for example, her beautician. Therefore, she cultivated an interest in Western high culture, and her close friend, Anna, worked at Hochsieben. She cooperated in the festival because, just like Yara and Ziba, she shared Behruz politics of making the exotic familiar in German contexts. 
However, she withdrew her participation abruptly after we had the following conversation on the telephone:

Nazanin "Last time I asked Behruz for the pink flyers, I wanted to distribute them. I spent the whole Saturday handing them out the city center and at the very end an elderly lady called me back, [and told me that] no date was indicated on it. This really frustrated me. I spent so much time distributing the flyers. I don't understand why he gave them to me."

Sonja "That's true. I also noticed that he is quite chaotic. That's a pity. $\mathrm{He}$ is still very inexperienced."

Nazanin "Yes, but then you have to be behind such a project. I had a call with Anna, again. She said that people [at Hochsieben] already laugh about Behruz. First, he wanted to reserve several concert halls, and then always less. Why did he start off so ambitious? Now we still have a hall fitting 800 people."

Sonja “Oh, 800? That's a lot!” (Field notes, April 2013)

Thus, Nazanin's evaluation of Behruz and his festival shifted when she perceived a lack of professionalism and saw it confirmed by the judgment of German cultural organizers. As we saw in Chap. 5, social fields may physically overlap and it is for this reason that Nazanin withdrew as a volunteer. Insecure about her inclusion in German social fields, she began to fear that instead of sustaining her revalorization of Iran-specific resources, the association with an unsuccessful project would renew barriers to her capital creation due to her cultural and racial Othering.

In sum, these five Iranians with whom Behruz interacted had different professional and private trajectories, disposed of different resources, and were involved in different social fields. Consequently, they followed different strategies of capital creation in the local Iranian social field, which were motivated by politics of value that varied between rejection (Danial), contestation of ( $\mathrm{Ziba}$ ), and committed engagement (Yara) with the system of value by which it is shaped.

Consequently, for each of them, different resources Behruz disposed of, or lacked, became decisive in the way they interacted with him. Interestingly, contrary to Behruz' expectations neither-except for Yaratook his collaboration with the Iranian government or his Arab identifications as a reason to refuse a collaboration. This may be due to Behruz' successful impression management ahead of the festival. Certainly, 
numerous people, like Milad, Hushang, and Babak did not come to the festival in the first place because they had decoded Behruz' political orientation before, as the singer Taghi is known for collaborating with the government.

These Iranian stakeholders based their decision to collaborate with him on the compatibility of his strategies of capital accumulation with their own engagements. Their interactions with Behruz highlight the way diversity among Hamburg's Iranians evolves: people are engaged in multiple, overlapping social fields shaped by competing systems of value. Through their interactions, they constantly confirm, modify, and contest the predominant system of value in the local Iranian social field; these individual and collective politics of value influence, and are influenced by, their potential for action within a multitude of other local and transnational social fields in which they individually are also engaged.

Hence, the ways in which they responded to Behruz' approach reveals their strategies of capital creation within and across these social fields and hints to their respective politics of value. The previous chapters already showed that, for people to work together in one way or another, it is the compatibility and not necessarily the closeness of their strategies of capital creation that is important. Relying on the same strategies of capital creation may rather encourage competition. However, the discussion of this chapter underlines that the parameters for successful collaboration shift with different temporalities: the longer the collaboration, the more important it may be for agents to follow, through their strategies of capital creation, similar or at least complementary politics of value.

\section{The Color Festival: Success or Failure?}

As Pnina Werbner (1999) reminds, there is no universally valid evaluation of failure and success. It is always relative to and evolves with the specific social conditions in which interactions take place. Was the festival a success from Behruz' point of view?

Two years after the festival, in 2015, the organizer commented on a social media website: "These were eight months of very practice oriented occupational training - only that they cost me 25.000€” (https://www. 
facebook.com/TheFUNHamburg/posts/000, assessed 14/03/2015). As a matter of fact, economic success seems to have been a crucial element in Behruz' retrospective evaluation. Indeed, the crowdfunding campaign, which mainly targeted Germans, did not even raise a third of the $€ 30,000$ budget. Behruz decided that he would pursue the project anyways, hoping, as he said, to at least break even through ticket sales, his own and his family's savings - and the secret Iranian government's contribution. However, this goal could not be reached: the Color festival took place in a hall fitting 800 people. However, on the three evenings altogether, only about 600 tickets were sold. It was Taghi's concert that reached the greatest audience, and it was also the only concert where the public was dominantly Iranian.

Given the barriers of capital creation that prevail in the German public sphere in relation to Iran-specific resources, Behruz lack of resources in the social field of cultural organizers and his half-hearted engagement in Iranian social fields, the number of festival-goers was actually not that small. A few months later, the FusIran festival, although being a collaboration between Golestan association and one of the most important cultural organizers in Hamburg, did not gather a greater public than the newcomer Behruz. The financial failure Behruz deplores was rather related to the choice of a too big and too expensive festival venue.

Behruz put the main blame for the festival's failure on Iranians, arguing that they did not support him. Revealingly, in an interview after the festival he said:

I don't really see myself as an Iranian. I know this saying: "You need to keep Arabs satisfied and Iranians hungry" [Arabhâ bâyad sir negahdâshteh bâshi, irânihâ bâyad goshneh negahdâshteh bâshi]. Iranians are always unhappy. Even if you give them everything, they want more. (Field notes, July 2015)

Thus, the experience of barriers to capital creation in German social fields had stirred in Behruz the hope to compensate the lack with the support of capital generated in the local Iranian social field. This was further encouraged by the fact that, in conformation to the prevalence of boundaries based on assumed cultural differences and notwithstanding the multicultural dimension of the event promoted among Germans, the staff at 
Hochsieben and some of the German visitors mainly perceived it as an event for Iranians. His politics of value had thus failed to be efficient enough in making the exotic familiar. Yet, this was a shortcoming about which Behruz did not speak.

Its consequence was that Behruz' expectations toward Iranians grew, while his strategies of capital creation remained the same. They were deceived, in great part, because his ambiguity about cooperation with Iranians caused him to be loath to put forward Iran-specific resources. As we see in the quote, in response, Behruz resolved to enforce boundaries based on ethnic identifications by devaluating Iranians and putting forward his Arab identifications. Correspondingly, the board of the festival's second edition in 2014 comprised only Germans and people of Arab origin and the program featured, besides Iranian, also Arab and European artists. However, Behruz failed again to raise enough funds and abandoned the project as a whole.

Just as we observed in Chap. 4, where Afshin had similarly ambitious politics of value in German social fields, in order to redefine the value of Iran-specific resources, important Germany-specific resources, time, and collective action are needed. Behruz, however, lacked Germany-specific resources, such as financial assets, a professional network, and experience, relevant to convey professionalism and solvability, and his fear of interdependency impeded on the emergence of durable collective action with Iranians. He thus found himself at the intersection of different systems of value creating barriers to his capital creation.

This chapter aimed at drawing the preceding findings together, in examining Behruz' strategies of capital creation in the social fields of the German public sphere, the local social field of cultural organizers and the local Iranian social field in organizing an Iranian cultural festival. In doing so, I traced his underlying politics of value and explained how different Iranian stakeholders engaged with him through boundary-making, in order to show why he perceived the festival to have been a professional failure.

The analysis of the interactions around the Color festival brought up-and thus stressed the relevance of-numerous factors which I showed play a role in social boundary-making among people of Iranian origin living in Hamburg in previous chapters: the agents' fluctuating 
and flexible ethnic and national identifications, their experience of kinship, the relevance of Germany- and Iran-specific resources in conveying crucial values in sometimes overlapping local and transnational social fields marked by historically rooted systems of value.

The discussion of this chapter showed clearly that there is no single system of value along which people of Iranian origin try to generate capital. Instead, their interactions take place at the intersection of multidimensional, convoluted, overlapping, dynamic, and interdependent social fields shaped by systems of value that are at times contradictory, intersecting, or complementary.

Behruz evaluated which people he asked for support on the basis of the compatibility of their strategies of capital creation with his-and so did the stakeholders when deciding whether to collaborate with him or not. Thus, social boundaries can not only represent imposed barriers to capital creation. People also actively use them to improve their capital creation: one can create or reinforce social boundaries if they generate capital, or try to deconstruct them, through impression management, if they impede on the valorization of resources.

Internal diversity, I suggest, is determined by the effect of a social relationship on the involved agents' respective strategies of capital creation and, more importantly, its coherence with their politics of value in the social field in which they meet, as well as through its possible impact on their agency in other social fields. Thus, although, for instance, nonIslamiosity is an important value for many people involved in the local Iranian social field, its relevance is never fixed but dependent on the agents' own politics of value and deriving strategies of capital creation in different social fields.

These arguments end the ethnographic component of this work. To close the circle, all that remains for me is to posit a few concluding remarks.

\section{References}

Adelkhah, Fariba. 1998. Ettre moderne en Iran. Paris: Karthala.

Bajoghli, Narges. 2019. Iran Reframed: Anxieties of Power in the Islamic Republic, Stanford Studies in Middle East. Stanford: Stanford University Press. 
Brehmer, Marian. 2013. Gemeinsam gegen Feindbilder. News. Qantara, July 11. http://de.qantara.de/content/bliss-festival-ein-blick-iran-sag-moin-undsalam-gemeinsam-gegen-feindbilder

Elling, Rasmus Christian. 2013. Minorities in Iran: Nationalism and Ethnicity After Khomeini. New York: Palgrave Macmillan.

Fekete, Liz. 2004. Anti-Muslim Racism and the European Security State. Race \& Class 46 (1): 3-29. https://doi.org/10.1177/0306396804045512.

Gholami, Reza. 2015. Secularism and Identity: non-Islamiosity in the Iranian Diaspora, Studies in Migration and Diaspora. Surrey/Burlington: Ashgate Publishing Limited.

Goffman, Erving. 1963. Stigma: Notes on the Management of Spoiled Identity. Englewood Cliffs: Prentice-Hall.

- 1990. The Presentation of Self in Everyday Life. London/New York/ Victoria/Toronto/New Delhi/Auckland/Johannesburg: Penguin Books.

Khosravi, Shahram. 1999. Displacement and Entrepreneurship: Iranian Small Businesses in Stockholm. Journal of Ethnic and Migration Studies 25 (3): 493-508. https://doi.org/10.1080/1369183X.1999.9976697.

- 2008. Young and Defiant in Tehran. Philadelphia: University of Pennsylvania Press.

- 2018. A Fragmented Diaspora: Iranians in Sweden. Nordic Journal of Migration Research 8 (2): 73-81. https://doi.org/10.1515/njmr-2018-0013.

Kokot, Waltraud. 2009. Diaspora as a Resource? Managing Social Capital in the Armenian Community of Sofia, Bulgaria. In Networks, Resources and Economic Action. Ethnographic Case Studies in Honor of Harmut Lang, Kulturanalysen, ed. Clemens Greiner and Waltraud Kokot, 127-150. Berlin: Dietrich Reimer Verlag.

Lamont, Michèle, Jessica S. Welburn, and Crystal M. Fleming. 2013. Responses to Discrimination and Social Resilience Under Neo- Liberalism: The United States Compared. In Social Resilience in the Neoliberal Era, ed. Peter A. Hall and Michèle Lamont, 129-157. Cambridge: Cambridge University Press.

Mauss, Marcel. 1966. The Gift: Forms and Functions of Exchange in Archaic Societies. London: Cohen \& West Ltd.

Moallem, Minou. 2000. 'Foreignness' and Be/Longing: Transnationalism and Immigrant Entrepreneurial Spaces. Comparative Studies of South Asia, Africa and the Middle East 20 (1-2): 200-216.

Moghadam, Amin. 2013. De l'Iran imaginé aux nouveaux foyers de l'Iran: Pratiques et espaces transnationaux des Iraniens à Dubaï. Arab Humanities [En Ligne] 2: 1-20. 
Nassehi-Behnam, Vida. 1991. Iranian Immigrants in France. In Iranian Refugees and Exiles Since Khomeini, ed. Ashgar Fathi, 102-116. Costa Mesa: Mazda Publishers.

Pedraza, Silvia. 2003. Cuba's Refugees: Manifold Migrations. In Cuban Communism: 1959-2003, ed. Irving Louis Horowitz and Jaime Suchlicki, 308-328. Brunswick: Transaction Publishers.

Portes, Alejandro. 1998. Social Capital: Its Origins and Applications in Modern Sociology. Annual Review of Sociology 24 (1): 1-24. https://doi.org/10.1146/ annurev.soc.24.1.1.

Sanadjian, Manuchehr. 2000. 'They Got Game’ Asylum Rights and Marginality in the Diaspora: The World-Cup and Iranian Exiles. Social Identities 6 (2): 143-164. https://doi.org/10.1080/13504630050032044.

Shooman, Yasemin. 2014. “... Weil ihre Kultur so ist”: Narrative des antimuslimischen Rassismus, Kultur Und Soziale Praxis. Bielefeld: transcript Verlag.

Werbner, Pnina. 1999. What Colour 'Success'? Distorting Value in Studies of Ethnic Entrepreneurship. The Sociological Review 47 (3): 548-579. https:// doi.org/10.1111/1467-954X.00184.

Open Access This chapter is licensed under the terms of the Creative Commons Attribution 4.0 International License (http://creativecommons.org/licenses/ by/4.0/), which permits use, sharing, adaptation, distribution and reproduction in any medium or format, as long as you give appropriate credit to the original author(s) and the source, provide a link to the Creative Commons licence and indicate if changes were made.

The images or other third party material in this chapter are included in the chapter's Creative Commons licence, unless indicated otherwise in a credit line to the material. If material is not included in the chapter's Creative Commons licence and your intended use is not permitted by statutory regulation or exceeds the permitted use, you will need to obtain permission directly from the copyright holder.

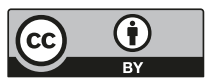




\section{7}

\section{Conclusion}

"Plurality is the condition of human action because we are all the same, that is, human, in such a way that nobody is ever the same as anyone else who ever lived, lives, or will live" (Arendt 1958, 8). For Hannah Arendt, plurality means both equality and diversity. Expressed in acts of differentiation, plurality forms the condition of political life. Differentiation necessarily requires initiative, thus plurality gives rise to creativity; it carries in it the seed of novelty (Arendt 1958, 175ff.). Yet, it is impossible to determine an exact and enduring definition of a single person, as his being is always in flux. Due to this extrinsic intangibility, all human relations are notoriously uncertain. Acts of differentiation always happen in social contexts and "it is because of this already existing web of human relationships, with its innumerable, conflicting wills and intentions, that action almost never achieves its purpose; but it is also because of this medium, in which action alone is real, that it 'produces' stories with or without intention" (idem 1958, 184). Through these stories, action becomes tangible, while remaining the result of human interactions whose agents, beginnings, and ends are not unequivocally identifiable.

This book essentially consists of incomplete ethnographic stories that explore the relationship between equality and diversity within webs of 
human relations, that is, social fields. Its aim is to explain the relation between differentiation among Hamburg-based people identifying (among other things) as Iranians and their past and ongoing historically situated experience of local and global relations of inequality. My main interest thereby lies in merchants' and artists' kinship and professional relations.

Bringing together research on internal differentiation and transnational social fields, I used Pierre Bourdieu's concept of capital creation within Michèle Lamont's boundary approach to focus on processes of evaluation. The focus on evaluation allowed me to connect this approach to David Graeber's anthropological theory of value, making it possible for me to identify migrants' motivation in their strategies of capital creation and point out the potential of collective and individual action within and at the intersection of different social fields. The aim of this approach was to grasp the way migrants engage with and in power relations without using a vocabulary that reads migrants' agency solely through the analytical lens of racism, Islamophobia, and exclusion. Instead, I highlighted empirically how these dynamics emerge in historical interrelation with social processes in the global south, thus revealing migrants' involvement in them, as well as their motivations and potential for acting upon them-or not. Perceiving internal diversity as a part of contemporary Western countries of immigration is crucial to understanding shifting internationally interconnected and historically rooted systems of value, grasping societal dynamics, and enhancing social cohesion.

\section{Internal Diversity}

I approached the study of internal diversity through processes of differentiation. I argued that boundary-making in internal relations needs to be understood with respect to the particularities of the social fields in which it takes place.

I showed that social fields mainly constituted by local Iranians are shaped-to different extents_-by relatively high levels of uncertainty. Uncertainty is high not only because of the modification of social ties through migration, but also because of Iranians' difficulties to transfer 
resources acquired in Iran to the German context, or to get recognition for their Germany-specific resources as capital. It also implies a relatively high level of interdependence (Faist 1998; Portes 1998; Bauder 2005; Zontini 2009). Uncertainty may increase when the social field of internal relations among migrants overlaps with other fields that are equally marked by uncertainty, as it is the case with professional fields that lack formalized mechanisms of evaluation (Apitzsch 2010), such as the international trade with Iranian carpets and the film business. I will come back to this observation below. My point here is that interdependence raises the stakes of boundary-making.

The ethnographic chapters showed that social boundaries between Iranians are never fixed, but subject to negotiation. Dimensions of commonality and difference are overlapping, sustaining and competing with each other in constant processes of negotiation. They are constructed and deconstructed through discursive or behavioral forms of inclusion and exclusion (Lamont 1992; Lamont and Molnár 2002). For instance, in telling me that the restaurateur Abtin was a Flüchtling (refugee), Akbar sought to disguise the fact that he himself had settled in Germany only after he had been granted asylum and stress his identification as a "traditional Iranian carpet merchant". Behavioral boundary-making was reflected, for example, in the collective dancing of Golestanis on the stage of the FusIran festival, which underlined the identification with the association Golestan, while indirectly excluding those who remained in the public. We can thus understand the construction and deconstruction of social boundaries as a mutual—situational_evaluation of the interacting agents' social, cultural, and economic resources (Moghaddari 2016).

There are numerous markers people use in boundary-making, and the ethnographic material presented in this study certainly could not reflect all of them. Certain markers of difference whose importance derives from their recurrence in diverse social contexts may be highlighted at this point: whether it is the personal experience of doing kinship and the resources inherited from previous generations, or being identified by others as a member of a specific family, I argued that kinship ties influence the way Iranians relate to one another. Gender and norms of gendered behavior also constitute reasons for boundary-making-not only in kinship relations. In the same vein, the construction of generational 
boundaries is recurrent, while the event of the Islamic revolution in 1979, in relation to personal religious adherences and political allegiances, is a pivot point in internal relations (Gholami 2014; Khosravi 2018). Class, ethnic, regional, and local identifications relative to Germany and Iran are also central to boundary-making, often in conflation with other forms of collective identifications that resonate with diverging motivations and conditions of immigration, represented in notions such as intellectuals, bazaris, honaris, or else the figure of the Flüchtling. Thus, markers used in Hamburg largely correspond to those extant research identified in other locations of Iranian immigration (Bozorgmehr et al. 1993; Bozorgmehr 1997; Sanadjian 2000; McAuliffe 2008). At the difference to newer destinations, however, long-established migrants in Hamburg are mostly merchants who tend to be more religious and/or friendly toward the current Iranian government than many post-1979 migrants. In this regard, dynamics of differentiation among Iranians in Hamburg are closer to those in other older locations of immigration, such as Dubai (Moghadam 2013, 2015; Adelkhah 2016).

In the literature on Iranian migration, this research contributes to rare studies who take truly transnational perspectives, in showing how Iranians' capital creation in transnational social fields influences their local inclusion (Ghorashi and Tavakoli 2006; Azadarmaki and Bahar 2007; Khosravi 2007; Ghorashi and Boersma 2009; SrebernyMohammadi 2013). Simultaneously, the case study fills the gap in (English-language) research about Iranian immigration in the earliest and today still one of the most important destinations of Iranian migration. Hamburg, in particular, a location that draws on a long history of economic and political ties to Iran, is a highly pertinent setting for further research on the role of migrants in Iran under international sanctions.

Within the great fluidity of social boundaries and the innumerous markers used, nearly all processes of social differentiation among Iranians in Hamburg are infused with definitions of Iranianness and Germanness. The relevance of these markers corresponds with research highlighting the importance of ethnic boundaries of Germany (Ehrkamp 2006; Bail 2008; Gruner 2010; Çelik 2017; Yilmaz Sener 2018). The identification or categorization as Iranian or German thus passes through the assessment of the volume and amount of resources judged as being 
Germany- and Iran-specific. Such resources are, for example, language skills and accent, knowledge of codes of politeness, clothing styles, gender norms, relevant social ties, and so on. The why and how of this observation requires a look at the values these resources convey among Iranians and in other local and transnational social fields-a discussion to which I turn below.

While plurality is the condition of human action, inequalities arise from the situational valorization of resources in processes of differentiation (Bourdieu 1979). The study showed that the construction and deconstruction of a social boundary can both enhance and hinder capital creation. Individual agents may thus try to circumvent barriers to their generation of capital by constructing or deconstructing social boundaries, putting forward certain resources, such as ethnic and national identifications, and dissimulating others through impression management (Goffman 1963). The approach I developed in this book thus showed that boundary-making may be considered as a tool in the generation of capital, not only among Iranians, but also in other social fields.

\section{Creating Capital Across Social Fields}

Building on the analysis of internal differentiation, I showed that Iranians living in Hamburg try to create capital in not only one, but in several multidimensional social fields, some of which, at least, are transnational. For instance, besides being involved in the local Iranian social field, Hushang also strives to create capital in the German and the transnational Iranian social field of film professionals. Depending on their personal trajectories and on the social fields in which they are engaged, Iranians follow highly diverse strategies of capital creation.

As I traced collective strategies of capital creation through identitary narratives, I interrogated the motivation behind such a management of resources across social fields. Building on the anthropology of value (Graeber 2001, 2013), I showed that processes of evaluation reveal the values that are central in the respective social field: if the resources people put forward mediate value within a social field, they get acknowledged as capital. Thus, social fields are shaped by systems of value. Strategies of 
capital creation arise when people try to enhance the efficiency of their resources within a given system. In doing so, they engage in what Graeber calls "politics of value", that is, constructing meaning that both acknowledges and resists existing systems of value. I will return to this below. It is politics of value that motivate people's strategies of capital creation.

Following up on Louis Dumont (2013), values thereby stand in relation to one another, some may be mutually exclusive, while others may be conditioned by key values. Expanding on Aihwa Ong (1999), who theorizes barriers to capital creation, I argued that limits arise when a person's resources fail to convey certain values within a social field. The barrier becomes more acute the more central these values are within the respective system.

Thus, going beyond extant research on transnational social fields (Levitt and Glick Schiller 2004; Erel 2010; Nowicka 2013), I identified two reasons why the creation of capital in internal relations interacts with the agents' individual positioning within and between social fields. First, social fields may physically overlap. For instance, if Hushang's German colleagues see him on a film festival in Hamburg with Milad, his association with someone whose resources fail to convey the key value of familiarity is received in the German social field of film professionals. At the same time, an Iranian colleague engaged in the Iranian transnational field of film professionals might perceive this collective public appearance as mediating the values of professionalism and cooperation. Thus, depending on Hushang's politics of value in different social fields and on their importance for his strategies of capital creation, he may seek closeness with Milad or try to construct boundaries in their relationship.

Second, systems of value prevailing in different social fields may intersect. In this study, the mutual influence of systems of value was particularly visible in the evaluation of Germany (or Western)-specific and Iran-specific resources. Let me illustrate this point with two examples. First, in Hamburg of the 1950s, local newspapers called people who, through their physical appearance, that is, race, or national origin, were marked as Middle Easterners "carpet-crooks" - they were perceived as unfamiliar. In order to create capital in the German carpet market, they needed resources that mediate the value of familiarity with German cultural contexts. Young sons of Iranian bazaris who came to Hamburg 
during these years liked to go to ball houses, and some of them had learnt European ballroom dances back in Iran. This was because merchant families were engaged in social fields in Iran under Shah Mohammad Reza Pahlavi, in which familiarity with Western cultural contexts was an important value. This was historically related to the fact that it was Western powers that had put the monarch on the throne in 1941 and helped him counter a democratic coup in 1953. His promoting values that correspond to dominant systems of value in the West signaled an effort to maintain their political support, thus perpetuating unequal global power relations.

Another example relates to the present-day German social sphere. I showed that in a local TV broadcast from 2013, young second-generation Iranians who put forward important Germany-specific resources were asked about their opinions on the political regime in Iran, and in particular on then-president Ahmadinejad. The journalist thus stressed the value of democracy, human rights, and equality-in its Western-centric understanding. Following the same logic, both in the systems of value prevailing among members of the association Golestan and in the transnational social field Iranian of honaris (constituted by artists and people close to the art scene), Iran-specific resources that convey opposition to the Iranian government and secularism-a value that may be termed, following Reza Gholami (2014), non-Islamiosity—tend to be acknowledged as capital. Resources that suggest regime-loyalty and adherence to the Islamic faith, instead, constitute a barrier to Iranians' capital creation in all three social fields as they suggest a lack of these values. Both examples show that systems of value that prevail in different social fields intersect, because historical interactions between unequally powerful agents in colonial and postcolonial contexts encouraged the integration of familiarity with the West, together with democracy, human rights, equality, and exoticism (in the perception of the ethnic and racial Other) as key values in many social fields across the world. In this point, this study joins postcolonial, feminist, and queer theory in highlighting the historical (re) production of global structures of inequality, including the involvement of migrants in it (Said 1978; Wolf 1982; Hooks 1986; Yuval-Davis 2007; Monsutti 2018). 
The pervasiveness of these originally Western values, in turn, accounts for the importance of the barrier to capital creation their lack inspires (see also Lamont 1992). This study thus confirms existing research on immigration to Europe indicating that, in German, but-I add-also in many Iranian social fields, a lack of resources considered as Germany- or Western-specific can constitute a barrier to the generation of capital (Cederberg 2012; Weiss 2001). Consequently, because social fields may overlap or systems of value may intersect, people consider the evaluation of their Iran- and Germany-specific resources and its effect on their strategies of capital creation in all social fields that they find relevant.

In sum, there is not a single system of value to which all Iranians adhere. Instead, depending on the historical and social characteristics of a specific social encounter and the personal and professional trajectories of the people interacting, various systems of value intersect and influence the way social boundaries are created. As boundary-making in internal relations serves to optimize Iranians' chances to generate capital, their social differentiation must be understood as an expression of competitive individual and collective politics of value, engaging with various systems of value that shape local and transnational social fields.

\section{Politics of Value and Potential for Action}

Reminding Arendt's thoughts, each act of differentiation is an initiative to act on the world and one's place in it. Yet, the fact that it is embedded in a web of relations thwarts the outcome-to varying degrees. Building on Graeber's anthropological theory of value allowed me to trace migrants' politics of value. Their potential for action, in turn, represents the power an agent has to influence the meaning of his resources in a social field.

To illustrate what I conceive of as politics of value, let us look at Iranians' different engagements with the system of value in a single social field: the German public sphere. As a reminder, familiarity with German cultural contexts through assimilation is a key value, alongside democracy, human right, equality, and exoticism. However, as multiple national or cultural identifications tend to be conceived as mutually exclusive (Sökefeld 2004; Ehrkamp 2006), it is quite impossible for an agent's 
resources to convey familiarity, as any resource identified as Iranian is accompanied by the misrecognition of Germany-specific resources. Thus, in this study, a very common approach among my interlocutors, such as Babak, the artist, was to put forward resources, such as accent-free German and knowledge of Iranian poetry, that convey familiarity (within the described limitations) and exoticism, while avoiding those resources, such as regime-loyalty, that mediate a lack of democracy. They often do so by staging Iranianness, and it may be through subliminal acts of overstretching the performance that they express critique of this system of value. A newer and upcoming approach, mostly observed among longestablished migrants, such as Omid the merchant, Behruz the cultural organizer, and Yara the educator, aimed at redefining the meaning of Iran-specific resources by promoting the exotic as familiar. Rarer are those people like Afshin, who follow the political goal to denationalize the meaning of their Iran-specific resources and promote the value of diversity as familiarity, stressing local belongings beyond any ethnic and national identification. Thus, compared to working-class Turks, who tend to reject the requirement of assimilation, this research confirms that middle-class Iranian professionals living in Germany tend to comply with this system of value even though they struggle with it (Sanadjian 1995; Ehrkamp 2006; Çelik 2015; Sadeghi 2018a, b). Indeed, the choice of the politics of value depends on migrants' unequal potential to act on existing systems of value.

Which are the factors that enhance the potential of action of people's politics of value? First, the volume and distribution of their resources as well as professional and personal trajectories will play an important role in the politics of value agents chose. The more Germany-specific resources one has, the higher is the potential for action in shaping the value of Iranspecific resources, as we saw in the conflict between Afshin and Babak. Second, it is much more efficient to pursue politics of value as a group rather than individually. In collaborations, however, we saw the importance of temporalities: while for short-term collaboration, such as the Color festival, it was enough for agents' strategies of capital creation to be compatible, in long-term alliances, such as among carpet merchants, in relevant social fields politics of value have to coincide or at least be compatible. 
The ways systems of value connect across social fields in relation to the migrants' potential to action are central to the negotiation of internal diversity. The two case studies of Iranian carpet merchants and members of association Golestan showcase great variation in this regard: Hamburg's Iranian carpet merchants largely recreated the system of value that historically prevails in the transnational social field of Iranian carpet merchants, while engaging in the German carpet market and in the field of Iranian foreign trade. In the 1950s, this approach caused barriers to capital creation in the German carpet market. By the 2010s, through a variety of shifts in the systems of value, merchants' collective politics of value succeeded in creating capital by mediating family cohesion, historical local rootedness, and professionalism in all three contexts, although their respective systems of value remained largely distinct. Their successful politics of value fostered strong internal cohesion but also high barriers to the inclusion of newcoming merchants.

In the second case, covering a much shorter time period, the system of value created within the association Golestan was new and thus less coherent, compared to the one prevailing among transnational Iranian merchants. It developed as an engagement to the systems of value that shape the social field of the German public sphere and the transnational social field related to the honari imaginary, which both intersect in giving key value to familiarity with German or Western cultural contexts and certain forms of exoticism. While the founder-members wanted to oppose these hegemonic systems by creating a counterpublic (Nicholls and Uitermark 2016), a growing number of members worked toward their internal system of value intersecting with those prevalent in the two other fields.

In a way, Iranian social fields are often used as a toolbox for the crafting of Iranian identifications that serve in politics of value among Germans. However, internal relations also offer people, like Yara, the occasion to challenge established collective (class-related) identifications and gain upward social mobility. For others, such as Solmaz, refusing an Iranian identification was a way to withdraw from Iranian social fields and contest their prevalent systems of value. Others again, like Afshin, Danial, and Behruz, displayed Iran-specific cultural resources among Germans, although they had disengaged from local and transnational Iranian social 
fields, often because they experienced the obligations attached to these relations as barriers to the creation of capital. The Iranian identifications my interlocutors displayed among Germans were a reinterpretation of collective identifications and imaginaries they nourished in local and transnational Iranian social fields. More research would be necessary to trace how these transnational renegotiations lead to respective readjustments of systems of value in Iran.

In tracing migrants' unequal potential for action within individual or collective politics of value, I acknowledge both their scope of action as well as its limits. In doing so, this research goes beyond studies of transnational migrants' strategies of capital creation that tend to either stress their possibility to challenge existing structures (Levitt and Glick Schiller 2004; Erel 2010; Nowicka 2013) or underline their subjugation to them (Ong 1992, 1996; Weiss 2005). Thus, people identifying as Iranians in Hamburg may confirm systems of value dominating in a specific social field and simultaneously contest them elsewhere (Martuccelli 2006). Or they may defy the same boundaries they contribute(d) to create in different social or historical contexts. Based on these reflections, we can understand internal boundary-making as a reflection of migrants' politics of value. In more general terms, these findings suggest that research on transnational strategies of capital creation should consider in further detail the complex ways in which valuations of different forms of capital may interact across diverse social fields in which agents may be engaged.

\section{Iranian-Germans?}

The study of diversity among Hamburg's Iranians showed that the system of value prevailing in the German public sphere stands in stark contrast with the lived reality of a growing part of the German population, which actively nourishes various cultural identifications. In the face of the large number of newcomers following the summer of 2015 and the ongoing crisis of the European border regime, it becomes even more important to understand the ways migrants partake in shaping changing systems of value in the German society (Vertovec 2015; Borneman and GhassemFachandi 2017; Fleischmann and Steinhilper 2017; Nowicka et al. 2017). 
The historical perspective on Iranian carpet merchants' collective politics of value showed that, despite the relative limitation of their potential for action, migrants' everyday collective action over long-time spans may influence the meaning of their resources and modify systems of value. Today, still, Hamburg-based people who call themselves "Iranians" tend to be referred to as "German-Iranians" (Deutsch-Iraner) or "Germans with migration background" in the press, stressing the Iranian as the more significant, that is, the determining, part of their identity. Yet, in the context of the refugee crisis, new social movements collectively try to reshape, similar to Afshin, Behruz, and Yara, the value of diversity or exoticism as connected to familiarity. Iranian public figures play an important role in this context (Moghaddari 2018). The historical perspective opens our view to the possibility that, one day in the far future, Iranians might call themselves "Iranian-Germans" (iranische Deutsche), as this book title suggests, or "Germans", or develop identifications beyond national categories. In order to grasp the changes which German and European societies undergo, a diachronic perspective is useful to further investigate relations among migrants of the same but also of different national and ethnic origins.

It is the role of research in social science to highlight contradictions and discrepancies in social life. In particular anthropology, here, has the capacity and probably also the vocation, to testify about the diversity that burgeons in contemporary-in particular European-societies. In this way, anthropology may contribute to raising a greater awareness about the value of plurality.

\section{References}

Adelkhah, Fariba. 2016. The Thousand and One Borders of Iran: Travel and Identity, Iranian Studies. New York/Abingdon: Taylor \& Francis.

Apitzsch, Birgit. 2010. Flexible Beschäftigung und soziale Netzwerke: Der

Einfluss von Professionalisierung. Edited by Jens Beckert and Christoph

Deutschmann. Wirtschaftssoziologie. Kölner Zeitschrift Für Soziologie Und Sozialpsychologie Sonderheft 49: 409-27.

Arendt, Hannah. 1958. The Human Condition: Second Edition. Chicago/

London: University of Chicago Press. 
Azadarmaki, Taghi, and Mehri Bahar. 2007. Emigration and Sociocultural Change in Iran. In The Cultures of Economic Migration. International Perspectives, ed. Suman Gupta and Tope Omoniyi, 143-158. Burlington/ Hampshire: Ashgate.

Bail, Christopher A. 2008. The Configuration of Symbolic Boundaries Against Immigrants in Europe. American Sociological Review 73 (1): 37-59.

Bauder, Harald. 2005. Habitus, Rules of the Labour Market and Employment Strategies of Immigrants in Vancouver, Canada. Social \& Cultural Geography 6 (1): 81-97.

Borneman, John, and Parvis Ghassem-Fachandi. 2017. The Concept of Stimmung: From Indifference to Xenophobia in Germany's Refugee Crisis. HAU: Journal of Ethnographic Theory 7 (3): 105-135. https://www.haujournal.org/index.php/hau/article/view/hau7.3.006

Bourdieu, Pierre. 1979. La Distinction. Critique Sociale Du Jugement. Paris: Editions de Minuit.

Bozorgmehr, Mehdi. 1997. Internal Ethnicity: Iranians in Los Angeles. Sociological Perspectives 40 (3): 387-408. https://doi.org/10.2307/1389449.

Bozorgmehr, Mehdi, Georges Sabagh, and Claudia Der-Martirosian. 1993. Beyond Nationality: Religio-Ethnic Diversity. In Irangeles: Iranians in Los Angeles, ed. Ron Kelley, Jonathan Friedlander, and Anita Colby, 59-80. Berkeley/Los Angeles/Oxford: University of California Press.

Cederberg, Maja. 2012. Migrant Networks and Beyond: Exploring the Value of the Notion of Social Capital for Making Sense of Ethnic Inequalities. Acta Sociologica 55 (1): 59-72.

Çelik, Çetin. 2015. 'Having a German Passport Will Not Make Me German': Reactive Ethnicity and Oppositional Identity Among Disadvantaged Male Turkish Second-Generation Youth in Germany. Ethnic and Racial Studies 38 (9): 1646-1662. https://doi.org/10.1080/01419870.2015.1018298.

. 2017. Disadvantaged, But Morally Superior: Ethnic Boundary Making Strategies of Second-Generation Male Turkish Immigrant Youth in Germany. Identities 25: 1-19. https://doi.org/10.1080/1070289X.2017.1305218.

Dumont, Louis. 2013. On Value: The Radcliffe-Brown Lecture in Social Anthropology, 1980. HAU: Journal of Ethnographic Theory 3 (1): 287-315. https://doi.org/10.14318/hau3.1.028.

Ehrkamp, Patricia. 2006. 'We Turks Are No Germans': Assimilation Discourses and the Dialectical Construction of Identities in Germany. Environment and Planning A 38 (9): 1673-1692. https://doi.org/10.1068/a38148.

Erel, Umut. 2010. Migrating Cultural Capital: Bourdieu in Migration Studies. Sociology 44 (4): 642-660. https://doi.org/10.1177/0038038510369363. 
Faist, Thomas. 1998. Transnational Social Spaces Out of International Migration: Evolution, Significance and Future Prospects. European Journal of Sociology 39 (2): 213-248.

Fleischmann, Larissa, and Elias Steinhilper. 2017. The Myth of Apolitical Volunteering for Refugees: German Welcome Culture and a New Dispositif of Helping. Social Inclusion 5 (3). Perspectives on the European Border Regime: Mobilization, Contestation, and the Role of Civil Society. https://doi. org/10.17645/Si.V5i3.945, September. https://www.cogitatiopress.com/ socialinclusion/article/view/945

Gholami, Reza. 2014. 'Is This Islamic Enough?' Intra-Diasporic Secularism and Religious Experience in the Shi' Iranian Diaspora in London. Journal of Ethnic and Migration Studies 40 (1): 60-78. https://doi.org/10.1080/13691 83X.2013.782150.

Ghorashi, Halleh, and Kees Boersma. 2009. The 'Iranian Diaspora' and the New Media: From Political Action to Humanitarian Help. Development and Change 40 (4): 667-691. https://doi.org/10.1111/j.1467-7660.2009.01567.x.

Ghorashi, Halleh, and Nayereh Tavakoli. 2006. Paradoxes of Transnational Space and Local Activism: Iranians Organizing Across Borders. Focaal European Journal of Anthropology 47: 90-102.

Goffman, Erving. 1963. Stigma: Notes on the Management of Spoiled Identity. Englewood Cliffs: Prentince-Hall.

Graeber, David. 2001. Toward an Anthropological Theory of Value: The False Coin of Our Own Dreams. Hampshire: Palgrave Macmillan.

- 2013. It Is Value That Brings Universes Into Being. HAU: Journal of Ethnographic Theory 3 (2): 219-243. https://doi.org/10.14318/hau3.2.012.

Gruner, Sabine. 2010. 'The Others Don't Want ...'. Small-Scale Segregation: Hegemonic Public Discourses and Racial Boundaries in German Neighbourhoods. Journal of Ethnic and Migration Studies 36 (2): 275-292. https://doi.org/10.1080/13691830903387402.

Hooks, Bell. 1986. Sisterhood: Political Solidarity Between Women. Feminist Review 23: 125-138. https://doi.org/10.2307/1394725.

Khosravi, Shahram. 2007. The 'Illegal' Traveller: An Auto-Ethnography of Borders. Social Anthropology 15 (3): 321-334. https://doi.org/10.1111/ j.0964-0282.2007.00019.x.

- 2018. A Fragmented Diaspora: Iranians in Sweden. Nordic Journal of Migration Research 8 (2): 73-81. https://doi.org/10.1515/njmr-2018-0013. Lamont, Michèle. 1992. Money, Morals, and Manners: The Culture of the French and the American Upper-Middle Class, Morality and Society Series. Chicago/ London: The University of Chicago Press. 
Lamont, Michèle, and Virág Molnár. 2002. The Study of Boundaries in the Social Sciences. Annual Review of Sociology 28 (1): 167-195. https://doi. org/10.1146/annurev.soc.28.110601.141107.

Levitt, Peggy, and Nina Glick Schiller. 2004. Conceptualizing Simultaneity: A Transnational Social Field Perspective on Society. International Migration Review 38 (3): 1002-1039. https://doi.org/10.1111/j.1747-7379.2004. tb00227.x.

Martuccelli, Danilo. 2006. Penser l'intermonde, ou comment oublier le problème de l'ordre social. Revue Du MAUSS 1 (27): 431-443.

McAuliffe, Cameron. 2008. Transnationalism Within: Internal Diversity in the Iranian Diaspora. Australian Geographer 39 (1): 63-80. https://doi. org/10.1080/00049180701877436.

Moghadam, Amin. 2013. Un espace social transnational entre les Émirats et le Sud de l'Iran: Les Khodmouni (Lârestâni) à Dubaï. ÉchoGéo [Online] 25. http://echogeo.revues.org/13554

- 2015. "Being Persian" au pays des Arabes. Hommes \& Migrations 1312: 23-30.

Moghaddari, Sonja. 2016. Fluid Identifications and Persistent Inequalities: Social Boundary Making Among Iranians in Hamburg. Anthropology of the Contemporary Middle East and Central Eurasia 3 (2): 97-119.

. 2018. 'Vibrationshintergrund': Intersectional Perspectives on Migranticized Public Figures' Positionalities in German Debates About Immigration. Paper Presented at the Workshop "Ask the 'Experts'? Positionalities of Researchers and Public Figures of Migrant Background in European Debates About Immigration", Göttingen, June 28.

Monsutti, Alessandro. 2018. Homo Itinerans: La Planète Des Afghans. Paris: Presses Universitaires de France - PUF.

Nicholls, Walter J., and Justus Uitermark. 2016. Migrant Cities: Place, Power, and Voice in the Era of Super Diversity. Journal of Ethnic and Migration Studies 42 (6): 877-892. https://doi.org/10.1080/1369183X.2015.1126088.

Nowicka, Magdalena. 2013. Positioning Strategies of Polish Entrepreneurs in Germany: Transnationalizing Bourdieu's Notion of Capital. International Sociology 28 (1): 29-47. https://doi.org/10.1177/0268580912468919.

Nowicka, Magdalena, Łukasz Krzyżowski, and Dennis Ohm. 2017. Transnational Solidarity, the Refugees and Open Societies in Europe. Current Sociology 67: 1-18. https://doi.org/10.1177/0011392117737817.

Ong, Aihwa. 1992. Limits to Cultural Accumulation: Chinese Capitalists on the American Pacific Rim. Annals of the New York Academy of Sciences 645 (1): 125-143. https://doi.org/10.1111/j.1749-6632.1992.tb33489.x. 
1996. Cultural Citizenship as Subject-Making: Immigrants Negotiate Racial and Cultural Boundaries in the United States [and Comments and Reply]. Current Anthropology 37 (5): 737-762. https://doi.org/10.2307/ 2744412.

1999. Flexible Citizenship: The Cultural Logics of Transnationality. Durham: Duke University Press.

Portes, Alejandro. 1998. Social Capital: Its Origins and Applications in Modern Sociology. Annual Review of Sociology 24 (1): 1-24. https://doi.org/10.1146/ annurev.soc.24.1.1.

Sadeghi, Sahar. 2018a. Host Discrimination, Bounded Mobility, and Bounded Belonging: Iranians in Germany. In The Iranian Diaspora: Challenges, Negotiations, and Transformations, ed. Mohsen Mobasher Mostafavi, 50-73. Austin: University of Texas Press.

- 2018b. Racial Boundaries, Stigma, and the Re-Emergence of 'Always Being Foreigners': Iranians and the Refugee Crisis in Germany. Ethnic and Racial Studies 42: 1-19. https://doi.org/10.1080/01419870.2018.1506145. Said, Edward W. 1978. Orientalism. New York: Vintage Books.

Sanadjian, Manuchehr. 1995. Temporality of 'Home' and Spatiality of Market in Exile: Iranians in Germany. New German Critique, Germany: East, West, and Other 64: 3-36.

- 2000. 'They Got Game' Asylum Rights and Marginality in the Diaspora: The World-Cup and Iranian Exiles. Social Identities 6 (2): 143-164. https://doi.org/10.1080/13504630050032044.

Sökefeld, Martin. 2004. Das Paradigma kultureller Differenz: Zur Forschung und Diskussion über Migranten aus der Türkei in Deutschland. In Jenseits des Paradigmas kultureller Differenz: Neue Perspektiven auf Einwanderer aus der Türkei, ed. Martin Sökefeld, 9-33. Bielefeld: transcript Verlag.

Sreberny-Mohammadi, Leili. 2013. Coffee Shops and Cigarettes: On the 'Return' to Tehran of Young Diasporic Iranians. Iranian Studies 46 (1): 115-130. https://doi.org/10.1080/00210862.2012.740900.

Vertovec, Steven. 2015. Flüchtlinge: Was Die Zuwanderung Mit Deutschland Macht. Süddeutsche Zeitung, October 28, sec. Flüchtlinge. http://www.sueddeutsche.de/politik/fluechtlinge-was-die-zuwanderung-mit-deutschlandmacht -1.2710550

Weiss, Anja. 2001. Rassismus als symbolisch vermittelte Dimension sozialer Ungerechtigkeit. In Klasse und Klassifikation. Die symbolische Dimension sozialer Ungerechtigkeit, ed. Anja Weiss, Cornelia Koppetsch, Albert Scharenberg, and Oliver Schmidtke, 79-108. Opladen: Westdeutscher Verlag. 
- 2005. The Transnationalization of Social Inequality: Conceptualizing Social Positions on a World Scale. Current Sociology 53 (4): 707-728.

Wolf, Eric. 1982. Europe and the People Without History. Berkeley/Los Angeles/ London: University of California Press.

Yilmaz Sener, Meltem. 2018. Perceived Discrimination as a Major Factor Behind Return Migration? The Return of Turkish Qualified Migrants from the USA and Germany. Journal of Ethnic and Migration Studies: 1-19. https://doi.org/ 10.1080/1369183X.2018.1524292.

Yuval-Davis, Nira. 2007. Intersectionality, Citizenship and Contemporary Politics of Belonging. Critical Review of International Social and Political Philosophy 10 (4): 561-574. https://doi.org/10.1080/13698230701660220. Zontini, Elisabetta. 2009. Enabling and Constraining Aspects of Social Capital in Migrant Families: Ethnicity, Gender and Generation. Ethnic and Racial Studies 33 (5): 816-831. https://doi.org/10.1080/01419870903254661.

Open Access This chapter is licensed under the terms of the Creative Commons Attribution 4.0 International License (http://creativecommons.org/licenses/ by/4.0/), which permits use, sharing, adaptation, distribution and reproduction in any medium or format, as long as you give appropriate credit to the original author(s) and the source, provide a link to the Creative Commons licence and indicate if changes were made.

The images or other third party material in this chapter are included in the chapter's Creative Commons licence, unless indicated otherwise in a credit line to the material. If material is not included in the chapter's Creative Commons licence and your intended use is not permitted by statutory regulation or exceeds the permitted use, you will need to obtain permission directly from the copyright holder.

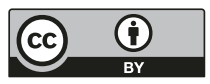




\section{Index ${ }^{1}$}

Anti-Muslim racism, 211

Arab, 209, 221, 222

Arendt, Hannah, 227

Artist, 1, 2, 19, 26, 125, 126, 129-131,

$131 \mathrm{n} 5,133,143,147-151$, 155, 167, 200, 205, 212, 214, $215,222,228,233,235$

Assimilation, 108, 137, 141, 146, 147, 155, 156, 167-175, 191, 212, 234, 235

Authenticity, 94, 95, 99, 103-105, $110,112,114$

Azari, 43n7

Azeri, 88, 143
B
Bazari, 42-45, 47, 48, 57n24, 60n31, 61n32, 90, 98, 100, 202, 230, 232

history of migration, 44 Bazari mindset, 54, 101

Boundary approach, 10, 11, 164, 228

Bourdieu, Pierre, 4, 8, 10-12, 21, 40, 49, 58, 59, 91, 93, 95, $126,175,228,231$

Brokerage, 171, 217
Capital, 5, 10-13, 40, 45-48, $82,126,163,198,228$, 231-234

Carpet trade, 83-85, 89, 90, 93, $100,104,106$

Citizenship, 138

Class, 8, 14, 15, 43, 83, 105, $116,129,133 \mathrm{n} 9,148$, $169,183,202,218,230$, 235

\footnotetext{
${ }^{1}$ Note: Page numbers followed by ' $n$ ' refer to notes.

(C) The Author(s) 2020 
Collective identifications, 26, 43, 82, $114,126,127,142,143$, 146-151, 155, 164, 230, 237

Ethnic identifications, 99

Counterpublic, 138, 142, 148,

155-156, 236

Diversity (internal differentiation), 5, 12, 19, 40, 103, 164, 220, 223, 228, 236

Diversity (value), 136, 141, 207, 235 diversity (internal differentiation), $5-8,228-231$

Downward-levelling social norms, 174, 209, 215

Ethnic identifications, 7, 21, 40, 48, $52,88,141,143,147,181$, 207, 209, 213, 222

Arab, 202, 209, 219

Azeri, 47

Exoticism, 140, 141, 146, 154, 170, 235

Familiarity, 94, 95, 97, 98, 104, 107-112, 114, 116, 128-130, 136-143, 145-147, 151, 154-156, 164, 169, 170, 172, $173,178,183,188,190,191$, 198, 201, 204-210, 212, 215, 232-236, 238

Film professionals, 26, 163-192, $211,231,232$
Flexible capital creation, 41, 45-48, $55,66-68,70,72,73,127$, 190

Gender, 8, 14, 40, 43, 46, 61, 64, $67,73,82,90,150,165,169$, 191, 229, 231

Generation, 15, 26, 44, 49, 60, 62, $73,81,112,114,145,150$, 180, 188, 190, 191, 229 generation of migrants, $4 \mathrm{n} 3,127$, 135

German public sphere, 127, 138, 139, 141, 146-148, 151, 154-156, 204, 206, 211, 212, 214, 217, 218, 221, 222, 234, 236, 237

Graeber, David, 10-12, 82, 91, 95, $99,102,106,115,228,231$, 232, 234

Guest worker, 16

HafenCity, 84, 111

Hamburg, 2, 13-19, 22, 24, 39, 39n1, 40, 42-50, 42n2, 42n5, 51n11, 53-57, 55n19, 55n20, 56n22, 59, 60n31, 62, 64-66, 69, 70, 74, 81-83, 85, 86, 88-93, 90n4, 91n5, 92n6, 92n7, 95-97, 98n14, 100-102, 104, 106, 107, 109, $111,112,114,125-129,135$, $143,150,152-155,165,167$, $168,171,174-176,180-186$, 188-190, 189n8, 197, 198, 
200-202, 204, 205, 207, 211,

$217,218,221,222,228$,

230-232, 236-238

Hanse, 42, 44, 150

History of migration, 13, 18, 24, 42

Germany, 16

Hamburg, 90

Honari, 127, 130-134, 144, 145. $150,151,155,156,230,233$, 236

Identity, 19, 21, 71, 72, 110, 131, 170, 209

Imam Ali mosque, 4, 22, 56, 83, $91 \mathrm{n} 5,96,97,113,187,210$

Impression management, 102, 115, 186-188, 191, 211, 219, 223, 231

Interdependence, 116, 208, 229

Iran, 14, 22, 210

Iran Haus Projekt, 108

Iranian foreign politics, 204

Iranian foreign politics, 100, 107, 210

Islam, 22, 23, 51, 51n13, 55, 71, 82, $115,133,135,169,211,223$

Islamic revolution, 13, 69, 86, 99, 102, 104, 150, 201, 230

Iranian foreign politics, 14

Keshavarzian, Arang, 43, 44, 46, 51, 57n24, 60n31, 61n32, 63n33, 87, 91, 94n10, 96, 100, 101, $105,107,113,114$

Khatami, Mohammad, 83, 100
Kinship, 40-44, 48, 52, 53, 57-59, $64,67,68,70-73,83,96$, 115, 129, 199, 203, 209, 210, $223,228,229$

Lamont, Michèle, 10, 228

IM

Marriage, 14, 41, 44, 49-52, 51n12, $5 \ln 13,5 \ln 14,64-67,69$, $69 n 38,70,87$

Merchants, 2, 18, 26, 39-74, $81-116,127,130,139,145$, 164, 190, 202, 209, 228-230, $233,235,236,238$

Methodology, 20, 83, 127, 128, 199

National Socialism, 47, 54, 55n20

Ong, Aihwa, 9, 41, 48, 60, 64, 67, 83, 91, 95, 101, 137, 164, $169,232,237$

Persian colony, 39, 92

Politics of value, 26, 99, 102-105, 110, 114-116, 127, 130, 138-140, 142-145, 151, 154-156, 170, 198, 199, 207, 208, 211, 212, 215-217, 219, $220,222,223,232,234-238$ 
Potential for action, 82, 106, 115, $116,127,141,145,220$, 234-238

Racial othering/racial difference, 19, $60,71,72,92,94,95,102$, $137,155,169-171,179,183$, 190, 191, 219

Hamburg, 53

Refugee, 18, 86, 99, 100, 103, 105, $141,176,181,183,186,229$, 238

Sanctions, 83, 204, 230

Schanzenviertel, 20, 130, 146, 148, 167, 168, 177, 202, 207

Shah Mohammad Reza Pahlavi, 54, $55,57,90-92,92 \mathrm{n} 7,93 \mathrm{n} 8$, $96 \mathrm{n} 13,233$

Iranian foreign politics, 93

Social field, 4, 8-10, 40, 82, 126,

164-167, 199, 228, 231-234

transnational social field, 4-6,

$8-10,12,48,56,70-73$, 95-98, 105, 112, 114-116, $126,127,130,138,151,155$, 156, 164-167, 171, 173, 174, 190, 199, 212, 215, 217, 220, 223, 228, 230-234, 236
Social mobility, 8, 51, 59, 72, 98, 130, 145, 150, 203, 215, 236 Speicherstadt, 81, 84, 85, 111 System of value, 91, 95, 96, 100-102, 104-106, 108, 109, $112,114-116,130,138,141$, $143,144,147-151,154,156$, 169-173, 178, 190, 199, 205, 206, 220, 223, 234-237

familiarity, 182
Tabriz, 39, 45, 54, 55, 86, 87, 90

Tehran, 20, 44, 57n25, 58, 64, 66, $102,111,113,129,131,132$, 132n7, 134, 163, 165, 168, $171,175,180,181,190,202$, 203

Transnational entrepreneurship, 83, 95, 102

Transnational family, 40, 41, 57, 64, 65,68

Transnational political activism, 128, $129,131,135,151,210$ Trust, 48, 49, 52, 58, 64, 98, 112, $130,144,145,173,174,187$, 190, 205, 208, 215

Werbner, Pnina, 6, 59-61, 64, 105, 112,220 